
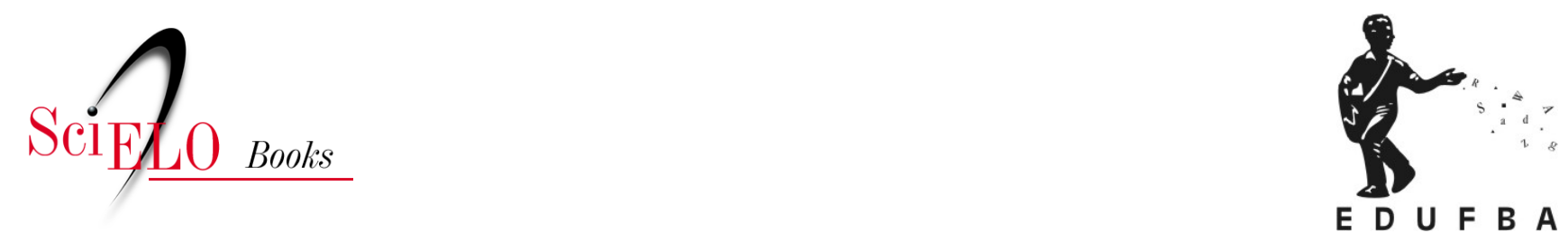

\title{
Gênero, direito e relações internacionais debates de um campo em construção
}

\author{
Denise Vitale \\ Renata Nagamine \\ (orgs.)
}

VITALE, D., and NAGAMINEM R., eds. Gênero, direito e relações internacionais: debates de um campo em construção [online]. Salvador: EDUFBA, 2018, 351 p. ISBN: 978-85-232-1863-8.

https://doi.org/10.7476/9788523218638.

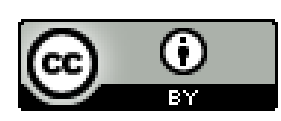

All the contents of this work, except where otherwise noted, is licensed under a Creative Commons Attribution $\underline{4.0 \text { International license. }}$

Todo o conteúdo deste trabalho, exceto quando houver ressalva, é publicado sob a licença Creative Commons Atribição 4.0. 


$$
\begin{aligned}
& \text { GÊNERO, } \\
& \text { DIREITOE } \\
& \text { RELAÇÕES } \\
& \text { INTERNACIONAIS } \\
& \text { debates de um } \\
& \text { campo } \\
& \text { em construção }
\end{aligned}
$$




\section{UNIVERSIDADE FEDERAL DA BAHIA}

REITOR

João Carlos Salles Pires da Silva

VICE-REITOR

Paulo Cesar Miguez de Oliveira

ASSESSOR DO REITOR

Paulo Costa Lima

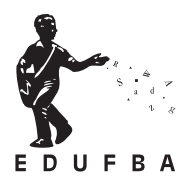

EDITORA DA UNIVERSIDADE FEDERAL DA BAHIA

DIRETORA

Flávia Goulart Mota Garcia Rosa

CONSELHO EDITORIAL

Alberto Brum Novaes

Angelo Szaniecki Perret Serpa

Caiuby Alves da Costa

Charbel Niño El-Hani

Cleise Furtado Mendes

Evelina de Carvalho Sá Hoisel

José Teixeira Cavalcante Filho

Maria do Carmo Soares de Freitas

Maria Vidal de Negreiros Camargo 
Denise Vitale

Renata Nagamine

Organizadoras

\section{GÊNERO, \\ DIREITOE \\ RELAÇÕES \\ INTERNACIONAIS \\ debates de um \\ campo \\ em construção}

Salvador

EDUFBA

2018 
2018, autores.

Direitos para esta edição cedidos à EDUFBA.

Feito o depósito legal.

Grafia atualizada conforme o Acordo Ortográfico da Língua Portuguesa de 1990,

em vigor no Brasil desde 2009.

PROJETOGRÁFICO

Gabriela Nascimento

REVISÃO

Denise Vitale

Renata Nagamine

NORMALIZAÇÃO

Flávia Rosa

Susane Barros

Sistemas de Bibliotecas/UFBA

Gênero, direito e relações internacionais: debates de um campo em construção/Denise Vitale, Renata Nagamine, organizadoras. - Salvador : EDUFBA, 2018.

$351 \mathrm{p}$.

ISBN: 978-85-232-1753-2

1. Mulheres - Condições sociais. 2. Direitos das mulheres. 3. Feminismo. 4. Violência contra as mulheres. 5. Ciências sociais. I. Título. II. Vitale, Denise. III. Nagamine, Renata.

CDD 305.42

Elaborado por Sandra Batista de Jesus - CRB-5/1914

Editorafiliada à:
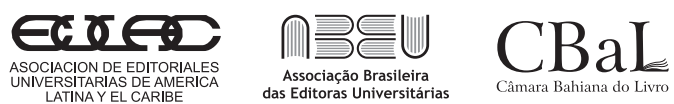

EDUFBA

Rua Barão de Jeremoabo, s/n Campus de Ondina

Salvador - Bahia CEP 40170-115 Tel: +55 (71) 3283-6164

www.edufba.ufba.br

edufba@ufba.br 


\section{SUMÁRIO}

Apresentação

GÊNERO, DIREITO E RELAÇÕES INTERNACIONAIS

\section{Parte I - Feminismo e Teoria Política}

1. TEORIA CRÍTICA E FEMINISMO: DISCUTINDO A RELAÇÃO Ingrid Cyfer

2. RESISTÊNCIA E OCUPAÇÃO DE ESPAÇOS: DEBATES FEMINISTAS E QUEEREM RELAÇÕESINTERNACIONAIS

Janina Onuki, Ana Balbachevsky Guilhon Albuquerque

e Arthur Murta

\section{Parte II • Mulheres, Direitos e Instituições}

3. GÊNERO E MOBILIZAÇÃO DO DIREITO NO BRASIL: VIOLÊNCIA E ABORTO, DOISCAMPOSDESIGUAIS

Marta Rodriguez de Assis Machado, Ana Luiza Villela de Viana Bandeira

e Fernanda Matsuda

4. OS PAPÉIS DA CORTE INTERAMERICANA DE DIREITOS HUMANOSE

DA CORTE EUROPEIA DE DIREITOS HUMANOS NO ENFRENTAMENTO

DA VIOLÊNCIA DE GÊNERO

Mariângela Gama de Magalhães Gomes

5. A RESPONSABILIDADE DO ESTADO BRASILEIRO NO CASO ALYNE PIMENTEL PELO CEDAW: MORTALIDADE MATERNA E DIREITOS REPRODUTIVOS SOB A ÓTICA DAS CRÍTICAS FEMINISTAS AOS DIREITOS HUMANOS Flávia de Ávila, Paula Alves Seixas e Karyna Batista Sposato 
6. SISTEMAS ELEITORAIS E PRESENÇA DAS MULHERES NA REPRESENTAÇÃO POLÍTICA: APONTAMENTOS DE UMA PERSPECTIVA COMPARADA ENTRE BRASIL, FINLÂNDIA E ÁUSTRIA

Maria Aparecida Azevedo Abreu

7. REFLEXÕES SOBRE IGUALDADE DE GÊNERO E OS ORGANISMOS INTERNACIONAIS

Ana Paula Martin Martins

8. A VIOLÊNCIA SEXUAL CONTRA A MULHER EM SITUAÇÃO DE CONFLITO ARMADO

Adriana Sader Tescari

\section{Parte III • Gênero e Cosmopolitismo}

9. A ONU MULHERES NA ALDEIA: ITERAÇÕES DEMOCRÁTICAS

E MEDIAÇÃO CULTURAL

Denise Vitale, Renata Nagamine e Giselle Amorim de Souza

10. COM LENÇO, SEM DOCUMENTO: GÊNERO, APATRIDIA E DIREITO NAS RELAÇÕESINTERNACIONAIS

Olívia Alves Barbosa

11. O FEMINISMO DAS GUERRILHEIRAS CURDAS DE ROJAVA Vitória Moreira

12. MARIELLE, PRESENTE! UM LUTO POLÍTICO E UMA RECONFIGURAÇÃO DA POLITICA NACIONAL - A NECESSÁRIA ARTICULAÇÃO DE UM PENSAMENTO LIBERAL BRASILEIRO QUE INCORPORE DEMANDAS SOCIAISE DE INCLUSÃO

Heloísa Pait e Renata Nagamine 


\section{APRESENTAÇÃO}

\section{Gênero, direitos e relações internacionais}

O feminismo, como objeto de ação social e pensamento, remonta ao século XVIII e, como debate acadêmico, aos anos 1920. É na década de 1920 que se forma o que chamamos de primeira onda feminista, ligada a demandas pelo direito das mulheres ao sufrágio. Embora outras ondas feministas tenham se seguido a essa, o feminismo se constituiu como tema de interesse global apenas na segunda metade dos anos 1990, para o que teriam concorrido processos internos aos Estados, a abertura do internacional a temas normativos com o fim da Guerra Fria e, mais especificamente, a Conferência das Nações Unidas sobre Mulheres, conhecida como Conferência de Pequim, em 1995. É nessa conferência que se dá o deslocamento da categoria "mulheres" por "gênero" e a adoção de uma abordagem particular dele, a mainstreaming ou da transversalidade.

Essa abordagem implicaria considerar o gênero, ao lado do desenvolvimento e do meio ambiente, uma dimensão que atravessa toda a agenda global, a ser contemplada, por isso, em deliberações e ações de órgãos, agências, programas e fundos das organizações internacionais. Sobretudo dos anos 2000, em diante, as questões relacionadas com o gênero ganharam, assim, maior densidade e destaque nas relações internacionais. Organizações internacionais como a Organização dos Estados Americanos (OEA), o Conselho da Europa, a União Europeia (UE) e a própria Organização das Nações Unidas (ONU) passaram a se engajar politicamente na promoção da agenda dos direitos das mulheres e da agenda LGBTI, atuando em parceria com Organizações Não Governamentais (ONG), redes de ativismo e Estados. Migrações, em especial de mulheres refugiadas, e a perseguição de pessoas LGBTI por sua orientação sexual e 
identidade de gênero, o estupro como arma em conflitos armados, a violência cotidiana contra a mulher, os seus direitos reprodutivos, a igualdade entre homens e mulheres, a autonomia das mulheres, as interseccionalidades que se conjugam em um ponto de vista único, a responsabilidade do Estado em matéria de direitos relacionados com o gênero são alguns temas tocantes às relações entre corpos femininos e corpos masculinos postos em questão no período.

Os anos 2000 e seguintes são, portanto, um período de grandes transformações nas relações sociais, as quais têm merecido a atenção da academia, inclusive a brasileira. Na esfera internacional, as questões de gênero têm suscitado um debate profícuo e uma importante produção acadêmica nas Ciências Sociais em sentido amplo há algumas décadas. Dois marcos na história dessa literatura são a publicação de The Boundaries of International Law: A Feminist Analysis, de Hilary Charlesworth e Christine Chinkin, em 2000, e de Gendering World Politics, de J. A. Tickner, em 2001. Passadas quase duas décadas de suas publicações, esses dois estudos seguem como referência para a pesquisa acadêmica, por sua qualidade, mas também pela surpreendente escassez de material sobre o assunto nos campos do Direito e nas Relações Internacionais durante um longo período de tempo, até começar a ser suprida mais recentemente.

Essa escassez é particularmente impressionante no Brasil, onde a discriminação e a violência contra a mulher são práticas comuns e só começaram a ser estudadas de maneira mais consistente, nas universidades brasileiras, nos anos 2000. É nesse período, e em sinergia com sua saliência nas relações internacionais, que o gênero emerge como um objeto de debate acadêmico e interesse fora dos muros da academia brasileira, a suscitar uma precipitação de discursos nas relações sociais. No que se refere ao debate acadêmico, ele ainda nos parece ser incipiente por um lado e, por outro, altamente qualificado, o que nos sugere que se trata de uma discussão entre poucas e boas pesquisas. O tema também tem despertado intensa curiosidade intelectual de alunos e alunas.

Os capítulos reunidos neste livro pretendem contribuir para o debate sobre o tema e fomentar o campo de estudos de gênero na fronteira entre o direito e as relações internacionais. Eles nascem da inquietação 
intelectual e do desejo de suas autoras de adensar as reflexões públicas em sentido amplo no Brasil, a partir da troca de ideias entre academia e sociedade. Neste livro, pesquisadoras com trajetórias acadêmicas e inserções institucionais distintas analisam o debate teórico sobre feminismo nos campos da teoria política e da teoria de relações internacionais, diferentes aspectos dos direitos das mulheres nas instituições internacionais e o gênero desde uma perspectiva cosmopolita. Por pressuposto temos que se trata de uma questão de justiça cuja problemática, complexa e atual, merece ser publicizada, analisada e amplamente discutida.

Este livro está organizado em três partes. Na primeira, intitulada Feminismo e Teoria Política, são apresentadas abordagens do gênero na teoria política e nas teorias de relações internacionais. No capítulo 1 , “Teoria crítica e feminismo: discutindo a relação”, Ingrid Cyfer analisa os caminhos da reflexão sobre a questão de gênero no âmbito da teoria crítica, explorando as possibilidades e limites dessa contribuição como referencial teórico e analítico. Na sequência, Janina Onuki, Ana Balbachevsky Guilhon Albuquerque e Arthur Murta analisam o processo de inserção das teorias feministas no conjunto das teorias de relações internacionais e suas potencialidades na conformação de uma nova abordagem normativa.

A segunda parte do livro, intitulada Mulheres, Direitos e Instituições, é composta por seis estudos e se volta para a temática de gênero no âmbito das organizações internacionais e das políticas públicas institucionais. No Capítulo 3, "Gênero e mobilização do direito no Brasil: violência e aborto, dois campos desiguais”, Marta Rodriguez de Assis Machado, Ana Luiza Villela de Viana Bandeira e Fernanda Matsuda analisam os processos de mobilização legal no campo de gênero, a partir de leis em sentido formal, como a Lei Maria da Penha e da Lei do Feminicídio, bem como da mobilização relativa ao direito ao aborto no Brasil, ainda em andamento. No Capítulo 4, "Os papéis da Corte Interamericana de Direitos Humanos e da Corte Europeia de Direitos Humanos no enfrentamento da violência de gênero", Mariângela Gama de Magalhães Gomes volta a atenção do leitor para os sistemas regionais de direitos humanos, analisando, a partir de dois casos específicos, o papel desempenhado pelos tribunais internacionais na proteção das mulheres. Em seguida, as autoras Flávia de Ávila, Paula 
Alves Seixas e Karyna Batista Sposato, em “A responsabilidade do Estado brasileiro no caso Alyne Pimentel pelo CEDAW: mortalidade materna e direitos reprodutivos sob a ótica das críticas feministas aos direitos humanos”, refletem sobre os avanços normativos e efeitos das recomendações produzidas pelo Comitê que cuida da implementação da Convenção no primeiro caso de condenação por morte materna (Capítulo 5).

O debate sobre a questão de gênero no âmbito institucional inclui ainda mais três contribuições. Em "Sistemas eleitorais e presença das mulheres na representação política: apontamentos de uma perspectiva comparada entre Brasil, Finlândia e Áustria (Capítulo 6), Maria Aparecida Azevedo Abreu analisa o aprimoramento institucional da igualdade entre homens e mulheres no sistema eleitoral, comparando a representação política no Brasil com a de países que adotam o sistema eleitoral proporcional de lista aberta. Na sequência, Ana Paula Martin Martins discute os mecanismos para os avanços da presença feminina em espaços transnacionais, em artigo intitulado "Reflexões sobre igualdade de gênero e os organismos internacionais” (Capítulo 7). Já no Capítulo 8, Adriana Sader Tescari analisa a violência sexual contra a mulher em situação de conflito armado, à luz do direito internacional e das ações nas relações internacionais voltadas para o enfrentamento do problema.

Na terceira e última parte do livro, sobre gênero e cosmopolitismo, são discutidos fenômenos políticos e sociais que envolvem a questão de gênero na relação dialética entre o global e o local. Esse bloco de debate é composto por quatro capítulos. O Capítulo 9, "A ONU Mulheres na aldeia: iterações democráticas e mediação cultural”, de autoria de Denise Vitale, Renata Nagamine e Giselle Amorim de Souza, discute o ativismo de mulheres indígenas brasileiras à luz de um possível "cosmopolitismo enraizado", com destaque para o papel da ONU Mulheres como espaço de mediação e das mulheres indígenas como mediadores no processo de articulação de um feminismo indígena no Brasil. Olívia Alves Barbosa, em "Com lenço, sem documento: gênero, apatridia e direito nas relações internacionais", analisa as relações entre gênero e apatridia, entendida como uma espécie de Outro da cidadania (Capítulo 10). Na sequência, Vitória Moreira discute "O feminismo das guerrilheiras curdas de 
Rojava”, (Capítulo 11) analisando o feminismo que emergiu com a autodenominada revolução de Rojava, em 2012, na Síria, do ponto de vista de sua concepção teórica e processo político-social. O livro se encerra com a contribuição de Heloisa Pait e Renata Nagamine "Marielle, Presente! Um luto político e uma reconfiguração da política nacional - a necessária articulação de um pensamento liberal brasileiro que incorpore demandas sociais e de inclusão" (Capítulo 12), no qual as autoras refletem sobre os desdobramentos sociopolíticos do assassinato da vereadora Marielle Franco, em março de 2018, com um olho no Brasil e outro para as relações entre o luto e a luta no Brasil com processos globais.

Distintos em forma e conteúdo, o conjunto de capítulos que apresentamos refletem pesquisas em estágios diferentes: algumas mais avançadas e maduras, outras mais exploratórias e de caráter mais ensaístico. Com todas as suas particularidades, eles compartilham da pretensão que motivou a publicação deste livro, que é colocar em circulação opiniões plurais acerca dos limites e das possibilidades dos direitos e ideias quando se trata de debater gênero na interface entre direito e relações internacionais. Esperamos que as ideias aqui reunidas incentivem novas reflexões e aprofundem o campo de estudos sobre o tema no Brasil.

Salvador, outubro de 2018.

Denise Vitale

Renata Nagamine

Organizadoras 
Parte I - Feminismo e Teoria Política 


\section{TEORIA CRÍTICA E FEMINISMO: \\ discutindo a relação}

Ingrid Cyfer 


\section{Introdução}

A primeira dificuldade que se apresenta quando se pretende discutir a relação entre teoria crítica e feminismo é o fato de tanto "teoria crítica" quanto "feminismo" serem expressões equívocas e extremamente disputadas no debate público e acadêmico.

No que se refere à teoria crítica, fala-se em "teoria crítica em sentido estrito" e em “sentido amplo". Em 1937, quando Max Horkheimer cunhou a expressão teoria crítica, diferenciando-a da teoria tradicional, a teoria crítica em sentido amplo era definida como aquela que tinha por referência a obra de Karl Marx, que, para Horkheimer, teria sido o primeiro teórico crítico. O sentido estrito de teoria crítica, por sua vez, referia-se mais especificamente à apropriação que Horkheimer fez de Marx na definição do método e tarefas da teoria crítica. (NOBRE, 2008, p. 22)

No entanto, se observarmos as teorias contemporâneas ao redor do mundo que se apropriam do "sintagma Critical Theory" (FERRARESE, 2018, p. 177) vamos encontrar um sentido de teoria crítica muito mais abrangente do que o "sentido amplo" de Horkheimer. Isso vale especialmente para as teorias críticas dos Estados Unidos. Amy Allen sintetizou de modo preciso o alcance que a expressão “teoria crítica” pode ter em seu país:

Nos EUA, falamos em Teoria Crítica tanto em termos de qualquer teoria que faça crítica aos mecanismos sociais vigentes - como o feminismo, a Teoria Queer, a Filosofia Crítica da Raça, a Teoria Pós-Colonial... Neste sentido, todas essas são consideradas teorias críticas (e são diferentes, por exemplo, de abordagens teóricas mais abstratas ou utópicas que estão interessadas em falar sobre como a sociedade deveria ser, sem olhar para como ela realmente é) - quanto em termos mais tradicionais, que se refere à tradição alemã da Escola de Frankfurt da Teoria Crítica Social. Então, o termo "teoria crítica" tem aplicações mais abrangentes ou mais restritas, e eu acho que as da tradição da Escola de Frankfurt não têm sido tão abertas ao feminismo e às questões de gênero nem, especialmente, às teorias críticas mais recentes, como a Teoria Queer e a Teoria Pós-Colonial, quanto talvez devessem ou pudessem ser. (ALLEN, 2016, p. 252) 
No que se refere ao termo feminismo, as dificuldades de definir seu sentido são tão grandes que, em vez de se falar em sentido amplo ou estrito, prefere-se utilizar a expressão "feminismos" para evitar o risco de se atribuir um sentido puro e fundador a dado movimento ou teoria.

Mas se as dificuldades de se determinar ambos os termos são tão grandes, do que se está realmente falando quando se utiliza a expressão “teoria crítica feminista”? A única resposta possível a essa questão é: estamos falando de muitas vertentes teóricas diferentes, especialmente se nosso critério para definir esse campo for, digamos, a "autodeclaração".

Neste breve texto, não tenho a pretensão de apresentar a diversidade e as disputas em torno das expressões "teoria crítica" e "feminismo", nem de fazer uma discussão aprofundada de critérios para distinguir teorias críticas de teoria tradicional no debate contemporâneo. Meu objetivo, aqui, restringe-se a contar um pouco dos processos de aproximação entre filósofas feministas e a teoria crítica frankfurtiana, que se deu com especial força nos Estados Unidos, ao menos no momento inicial. Em seguida, abordarei brevemente a repercussão dessas apropriações na universidade brasileira, ainda bastante recente e carente de estudos sobre o processo de sua consolidação acadêmica. Finalmente, concluo com alguns apontamentos sobre as possibilidades que se abrem para essa área no Brasil.

\section{Da teoria crítica ao feminismo e vice-versa}

O Instituto de Pesquisa Social (Institut für Sozialforschung) foi fundado em 3 de fevereiro de 1923, tendo sido vinculado à Universidade de Frankfurt em 1924. Em seus primeiros anos, o Instituto teve Carl Gruenberg, historiador marxista de Viena, como diretor. Em 1930, o jovem filósofo Max Horkheimer substituiria Gruenberg na direção e assumiria a cátedra de filosofia social. (FREITAG, 2004)

Ao assumir o cargo, Horkheimer redireciona o foco do Instituto, mudando sua ênfase original em pesquisas voltadas para a história do socialismo e do movimento operário para assumir características de um núcleo de pesquisa voltado para a análise crítica dos problemas do capitalismo. Por isso, a primeira Revista do Instituto denominada Archiv, cujo foco 
eram estudos históricos, será substituída pela Revista de Pesquisa Social, que teve seu primeiro número publicado em 1932.

Entre 1933 e 1950, o Instituto, que reunia muitos intelectuais judeus, teve de emigrar. Inicialmente se transferiu para Genebra, onde alguns nomes que viriam a ser protagonistas na teoria crítica se filiaram a ele, como Friederich Pollock, Erich Fromm e Franz Neumann. Em 1934, o Instituto se mudou novamente, desta vez para Nova York, vinculando-se à Universidade de Columbia.

Foi durante o período de exílio nos Estados Unidos que foram publicadas as principais obras da primeira geração da Teoria Crítica, entre as quais, A personalidade autoritária, a coletânea de ensaios de Theodore Adorno e Horkheimer, A dialética do esclarecimento (1947), além do texto de Horkheimer que lança os fundamentos de teoria crítica, Teoria tradicional e teoria crítica (1937).

No artigo de 1937, Horkheimer apresenta os dois princípios básicos da teoria crítica, extraídos de sua análise da economia política de Marx: a) a orientação para emancipação, b) o comportamento crítico. (NOBRE, 2008, p. 31) De acordo com o primeiro princípio:

[...] é a própria perspectiva da emancipação que torna possível a teoria, pois é ela que abre pela primeira vez o caminho para a efetiva compreensão das relações sociais [...] Dito de outra maneira, é a orientação para emancipação que permite compreender a sociedade em seu conjunto, que permite pela primeira vez a constituição de uma teoria em sentido enfático. (NOBRE, 2008, p.32)

O comportamento crítico, por sua vez, indica que a teoria crítica não se limita a descrever o mundo social, mas o examina da perspectiva da distância que separa o que existe do que pode existir. (NOBRE, 2008; HORKHEIMER, 1989)

Em A dialética do esclarecimento, publicado em parceria com Adorno dez anos depois, os filósofos empreendem uma investigação sobre a razão humana orientada por esses princípios. A questão central do livro é entender como a razão foi confinada em um: 
[...] processo técnico, no qual o sujeito se coisificou após sua eliminação da consciência, [que] está livre da plurivocidade do pensamento mítico bem como de toda significação em geral, porque a própria razão se tornou um mero adminículo da aparelhagem econômica que a tudo engloba. Ela é usada como um instrumento universal servindo para a fabricação de todos os demais instrumentos. Rigidamente funcionalizada, ela é tão fatal quanto a manipulação calculada com exatidão na produção material e cujos resultados para os homens escapam a todo cálculo. Cumpriu-se afinal sua velha ambição de ser um órgão puro dos fins. (ADORNO; HORKHEIMER, 1985, p. 41)

É essa concepção de razão que Adorno e Horkheimer consideram ser a única forma de racionalidade que se pode encontrar no capitalismo tardio e, por isso, não têm outra saída a não ser reconhecer que se defrontaram com uma aporia: a autodestruição do esclarecimento. Dizem os autores:

Não alimentamos dúvida nenhuma - e nisso reside nossa petitio principii - de que a liberdade na sociedade é inseparável do pensamento esclarecedor. Contudo, acreditamos ter reconhecido com a mesma clareza que o próprio conceito desse pensamento, tanto quanto as formas históricas concretas, as instituições da sociedade com as quais está entrelaçado, contêm o germe para a regressão que hoje tem lugar por toda parte. Se o esclarecimento não acolhe dentro de si a reflexão sobre esse elemento regressivo, ele está selando seu próprio destino. Abandonando a seus inimigos a reflexão sobre o elemento destrutivo do progresso, o pensamento cegamente pragmatizado perde seu caráter superador e, por isso, também sua relação com a verdade. A disposição enigmática das massas educadas tecnologicamente a deixar dominar-se pelo fascínio de um despotismo qualquer, sua afinidade autodestrutiva com a paranóia racista, todo esse absurdo incompreendido manifesta a fraqueza do poder de compreensão do pensamento teórico atual. (ADORNO; HORKHEIMER, 1985, p. 13)

Esse diagnóstico pessimista será desafiado pelo grande expoente da segunda geração da teoria crítica, Jürgen Habermas, para quem a aporia a 
que Adorno e Horkheimer chegam revela uma fragilização dos dois princípios fundamentais da teoria crítica, aqueles mesmos princípios propostos pelo próprio Horkheimer em "Teoria Tradicional e Teoria Crítica”.

Habermas compartilha com a Dialética a tese do capitalismo regulado pelo Estado que neutraliza as tendências para emancipação, tal como compreendidas pela teoria marxista (colapso interno em função da queda do lucro e a conscientização de classe do proletariado). No entanto, contra a Dialética, afirma que o capitalismo administrado não bloqueia estruturalmente a possibilidade de emancipação. Mas, para enxergar esses potenciais emancipatórios, seria preciso rever o próprio sentido de razão e de emancipação. Habermas defende a necessidade de a teoria crítica ampliar seus temas e encontrar um novo paradigma explicativo, pois as formulações originais de Marx não seriam mais suficientemente críticas para a realidade atual.

Assim como fez a Dialética, Habermas empreende uma investigação sobre a razão humana, mas chega a respostas diferentes das de Horkheimer e Adorno, justamente porque o novo paradigma que propõe, o da Teoria da Ação Comunicativa, tornaria possível a retomada da "[...] empreitada que foi interrompida com a crítica da razão instrumental”. (HABERMAS, 1984, p.386)

Para Habermas, a racionalidade instrumental não deve ser demonizada, ela deve, sim, ser diferenciada de outro tipo de racionalidade característica da modernidade: a racionalidade comunicativa. Essas duas formas de racionalidade não competem ou conflitam entre si necessariamente. Na visão de Habermas, elas são ambas necessárias e complementares. No entanto, podem se tornar antagônicas quando uma delas extrapola seus respectivos domínios. E, segundo seu diagnóstico do tempo presente, é precisamente isso que estaria havendo: a colonização do mundo da vida, espaço próprio da razão comunicativa, pelo sistema, domínio próprio da razão instrumental. Ou seja, os “[...] mecanismos sistêmicos [estariam] suprimindo formas de integração social, mesmo naquelas áreas nas quais a coordenação da ação consenso-dependente não pode ser substituída, isto é, [nas áreas] onde a reprodução simbólica do mundo da vida está em 
questão. Nessas áreas, a mediatização do mundo da vida assume a forma de colonização". (HABERMAS, 1984, p. 196)

No que se refere à reformulação da noção de emancipação, pode-se dizer que o modelo crítico de Habermas representará uma inflexão em relação à geração anterior, pois nesse autor a emancipação deixará de estar associada à revolução. Os potenciais emancipatórios em Habermas são buscados nos próprios mecanismos de participação do Estado democrático de direito. Não por acaso, sua reflexão sobre razão, ação, ética e discurso desembocará em sua obra de 1992, Direito e democracia: entre faticidade evalidade.

O pensamento de Habermas teve grande repercussão em todo mundo, trazendo novos temas, métodos e debates para o campo da teoria crítica; e não passou despercebido pelas filósofas estadunidenses que vêm sendo apontadas como a primeira geração da teoria crítica feminista, ${ }^{1}$ Nancy Fraser, Seyla Benhabib e Iris Young. ${ }^{2}$ Na verdade, será sobretudo em Habermas que encontrarão inspiração para tornar o feminismo mais crítico, e a teoria crítica mais feminista.

Curiosamente, Adorno e Horkheimer não foram, ao menos não num primeiro momento, as principais referências. Apesar de terem-se estabelecido nos Estados Unidos entre 1934 e 1950, sua passagem por ali não suscitou grande engajamento da academia norte-americana com os textos e os projetos da teoria crítica. Em parte, porque Adorno e Horkheimer viviam nos Estados Unidos na década de 1940 "como se estivessem em Frankfurt ou Genebra, discutindo e filosofando em alemão. [...] Esse enclausuramento lingüístico intencional e possivelmente necessário para a

1 Apesar de utilizar aqui a expressão "primeira geração da teoria crítica feminista”, não pretendo sugerir com isso uma separação entre teoria crítica feminista e teoria crítica não feminista. Afinal, as próprias feministas não fazem essa distinção. Elas não se definem como um grupo separado e em oposição aos filósofos frankfurtianos. Ao contrário, é por um meio de uma intensa interlocução com tais autores que cada uma delas articula suas respectivas teorias. Em seus trabalhos, gênero parece ser antes um olhar que atravessa todas as suas reflexões políticas do que um campo autônomo e impermeável. Além disso, esse tipo de separação tampouco faria sentido porque uma teoria crítica cega ou indiferente às questões de gênero não poderia ser hoje considerada realmente crítica. Agradeço a Adriana P. Matos por mealertar para este último ponto.

Para uma introdução aos modelos críticos das três autoras ver Gonçalves (2013). 
sobrevivência do grupo no exílio acabou isolando-o das demais correntes do pensamento americano". (FREITAG, 2004, p. 135) Exceção feita a Marcuse, Fromm, e Neumann que se estabeleceram nos Estados Unidos e não retornaram do exílio para Frankfurt. Esses autores passaram a escrever em inglês, o que lhes garantiu maior divulgação e popularidade de suas ideias. (FREITAG, 2004, p. 131)

No caso de Marcuse, a repercussão de sua obra foi ainda maior depois que o movimento estudantil de 1968 e 1969 passou a vê-lo como o ideólogo da Nova Esquerda. Segundo Freitag, seu protagonismo nesse contexto era tão grande que foi somente com sua ida a Paris e Berlim, em maio de 1968, "que surgiu a tendência de caracterizá-los [os filósofos da Escola de Frankfurt] como escola, sob o rótulo de 'teoria critica da sociedade': a visão de síntese e a nomenclatura foram um fenômeno claramente $a$ posteriori", como se vê na entrevista concedida por Habermas a Honneth e Bonss (1985 apud FREITAG, 2004, p. 131) Diz o filósofo:

Para mim não existia uma teoria crítica, uma doutrina de alguma forma coerente. Adorno escrevia ensaios críticos e realizava, além disso, seminários sobre Hegel. Ele concretizava um certo plano de fundo - era isso. Somente no final dos anos 60 é que jovens inteligentes se conscientizaram do fato de que a teoria crítica da sociedade viria um dia a ter um caráter sistemático

Nessa época, Nancy Fraser, Iris Young e Seyla Benhabib eram estudantes de filosofia e ativistas feministas. As três autoras, formadas num contexto em que a hegemonia da filosofia analítica e do behaviorismo na ciência política começava a declinar, encontraram um caminho mais aberto para a exploração de perspectivas teóricas que pudessem ser produtivas para interpretar, pensar e agir no contexto turbulento e inovador que viviam naquele momento. Apesar disso, em seu período de doutorado, Fraser, por exemplo, disse que "precisou educar-se a si mesma", pois, em seu departamento na CUNY (City University of New York), mal se estudava filosofia continental, e menos ainda Teoria Crítica". (FREITAG, 2004, p. 132) 
No entanto, embora a teoria crítica na década de 1970 estivesse longe de estar consolidada nas universidades estadunidenses, os intensos debates naquele país e em todo mundo em torno de John Rawls, que havia lançado sua obra Uma teoria da justiça em 1971, e a repercussão do engajamento de Jürgen Habermas nesse debate trariam ainda mais destaque para a teoria crítica no país. Além disso, Martin Jay havia, já em 1973, escrito seu livro Dialectical Imagination, no qual conta a história do Instituto em sua fase europeia e norte-americana. (FREITAG, 2004, p. 132)

Embora a recepção da teoria crítica nos EUA não tenha sido incontroversa, ${ }^{3}$ a Escola de Frankfurt começa a ganhar cada vez mais espaço no final da década de 1970, especialmente a obra de Habermas. (FREITAG, 2004, p. 133) Um dos mais importantes impulsos para intensificar o interesse por seu trabalho foi a publicação do livro The Critical Theory of Jürgen Habermas (1978), de Thomas McCarthy, além da tradução para o inglês dos dois volumes da Teoria da ação comunicativa, realizada também por McCarthy. (FREITAG, 2004, p. 136)

Thomas McCarthy, apontado com frequência como principal especialista em Habermas nos Estados Unidos, foi um importante interlocutor e parceiro acadêmico de ao menos duas das principais autoras mencionadas anteriormente. Nancy Fraser conheceu McCarthy na Northwestern University. Na realidade, foi uma das responsáveis por sua contratação, o que viria a tornar o departamento de filosofia dessa universidade fortemente comprometido com a teoria crítica, especialmente com o modelo habermasiano. Fraser reconhece que teve uma experiência privilegiada no ambiente acadêmico da Northwestern, que lhe permitiu formar novas gerações na teoria crítica dos Estados Unidos, inclusive a feminista, ${ }^{4} \mathrm{em}$ um prestigiado departamento de filosofia. ${ }^{5}$ (NICHEL, 2O12)

3 Habermas e Adorno não raro eram alvo de críticas que os acusavam de "excesso de teoria" e de "falta de correspondência entre o conceitual teórico muito abstrato e a realidade empírica".

4 Amy Allen talvez seja o nome mais destacado da $2^{a}$ geração de teoria crítica feminista formada por Fraser e McCarthy na Northwestern.

5 Sobre a trajetória de Fraser ver também Cyfer e Neves (2011). 
Seyla Benhabib e Thomas McCarthy também se encontraram em razão do interesse de ambos pelo pensamento habermasiano, mas o teórico crítico que a atraiu da Turquia para os Estados Unidos foi Marcuse, e não Habermas. Benhabib foi estudar em Brandeis onde esperava ter Marcuse como professor. No entanto, quando chegou lá, o filósofo já havia se mudado para San Diego. Mais tarde, foi pra Yale fazer o Doutorado, e a proximidade com Nova York intensificou sua participação em grupos políticos de intelectuais de esquerda, onde conheceu Nancy Fraser e Linda Nicholson. Além disso, Benhabib passou a frequentar os cursos de Hannah Arendt sobre Kant, na New School for Social Research, uma autora que viria a ter um impacto decisivo em todo o seu trabalho.

O encontro de Benhabib com Habermas se deu, aliás, mediado pela obra arendtiana. Habermas foi a Yale proferir uma palestra sobre Arendt, e Benhabib lhe fez algumas perguntas sobre sua fala. Pouco depois, iria trabalhar com ele na Alemanha, inicialmente no Instituto Max Planck e, posteriormente, em Frankfurt. Benhabib ficaria na Alemanha por cerca de 10 anos. Mas mesmo depois de conseguir seu primeiro emprego nos Estados Unidos, na Boston University, manteve-se fortemente ligada ao país, transitando entre ele e os Estados Unidos: passava um semestre dando aula nos Estados Unidos e o outro trabalhando no que viria a ser seu primeiro livro, Critique, Norm and Utopia, na Alemanha. A Boston University não se opôs de modo algum a esse arranjo. Provavelmente porque o chefe de seu departamento era ninguém menos do que Thomas McCarthy, que estava, afinal, tão interessado quanto ela nessa interlocução com Habermas. (NICHEL, 2012, p. 92)

Finalmente, a conexão entre Iris Young e a Escola de Frankfurt, em particular com pensamento de Habermas, era bastante estreita, tendo a filósofa chegado a passar o ano de 1995 em Frankfurt como professora convidada. Embora tivesse como questão central um problema que parecia passar ao largo das temáticas habermasianas, a política da diferença, Young encontrou em Habermas recursos para situar essa discussão no contexto de uma reflexão sobre democracia, ainda que o tenha feito por meio de uma apropriação crítica que reformula a concepção 
habermasiana de comunicação, dando mais espaço para abordagens pós -estruturalistas da linguagem. ${ }^{6}$

No entanto, não se pode dizer que a combinação entre a teoria crítica habermasiana e o pós-estruturalismo fosse uma especificidade de Young. Há quem diga, inclusive, que a "virada pós-moderna" é uma marca da teoria crítica norte americana. (NICHEL, 2012, p. 1) Se considerarmos as feministas, ao menos, essa parece ser realmente uma característica recorrente. Entre as pioneiras, além de Young, Fraser reivindica desde os anos 1980 que a tensão entre pós-estruturalismo e teoria crítica habermasiana é uma "falsa antítese". (FRASER, 1981, 1995)

Benhabib, porém, foi mais comedida nessa relação. Segundo a própria filósofa, isso aconteceu porque nos dez anos que passou na Alemanha "havia mais um confronto [com o pós-modernismo]", enquanto, nos Estados Unidos, “todos haviam comprado essa ideia”. (NICHEL, 2012, p. 92) Mas, ao retornar àquele país, Benhabib de alguma forma se engajou também na discussão pós-estruturalista, ainda que tenha sido para rejeitar sua compatibilidade ou colaboração com a teoria crítica. Foi em torno dessa questão que surgiu uma das coletâneas mais importantes sobre o debate da teoria crítica feminista norte-americana, Feminist Contentions, da qual Benhabib é uma das organizadoras. ${ }^{7}$ (BENHABIB, 1995)

Em suma, como se pode ver, embora a presença do pensamento habermasiano na chamada primeira geração da teoria crítica feminista fosse inegável, a apropriação que fizeram desafiava muitas das ideias do autor, inclusive sua objeção ao pós-estruturalismo na teoria crítica. Além disso, mesmo autoras como Benhabib, que se afinam mais com essa objeção, procuraram ir além de Habermas no que refere a "excessos racionalistas" de sua teoria. (BENHABIB, 1992) Além de Habermas, Axel Honneth, o principal ícone da terceira geração da teoria crítica frankfurtiana, foi e é também um importante interlocutor das teóricas críticas feministas, sendo que seu debate com Nancy Fraser chegou a se transformar em um dos livros de maior repercussão dessa geração, Redistribution or Recognition?: A Political Philosophical Exchange, publicado pela primeira vez em 2003.

6 Ver Young (1990). Ver também Neves (2005).

7 Sobre esse debate, ver Cyfer (2009). 
No Brasil a discussão feminista tardaria a chegar, muito embora o pensamento da primeira geração da teoria crítica já tivesse sido incorporado por aqui desde a década de 1960. Freitag (2012, p. 139), citando o ensaio de Carlos Coutinho (1986), afirma que a recepção da teoria crítica no Brasil se fez em duas etapas:

a primeira teria se dado via Marcuse (e, portanto, através dos Estados Unidos), assumindo entre nós uma colaboração contracultural e irracionalista. A segunda, ocorrida no final da década de 1970, mediatizada por Rouanet, assumiria uma conotação radicalmente racionalista, buscando recuperar na teoria crítica seu elemento iluminista original". (FRETAG, 2012, p. 139)

Além dessas, pode-se dizer também que há uma terceira e já talvez quarta. A terceira me parece que é a incorporação da teoria crítica habermasiana no contexto de reflexões sobre redemocratização. Foi pela influência que a teoria crítica da primeira geração já tinha no Brasil, especialmente nas áreas de sociologia da comunicação, estética, e entre intelectuais marxistas, que surge o interesse em acompanhar os desdobramentos e inovações na teoria crítica trazidas pela obra de Habermas, especialmente suas divergências com a primeira geração no que se refere a seu distanciamento da herança marxista.

Na década de 1980, Gabriel Cohn ministrou o que foi provavelmente o primeiro curso centrado na obra de Habermas e Rawls (ARAÚJO; ASSUMPÇÃO, 2010), deslocando a reflexão no campo da teoria crítica brasileira para questões sobre justiça e democracia. Esse deslocamento se encaixaria perfeitamente nas demandas teórico-políticas pós-redemocratização. A obra de Habermas, que trará a reboque a de Rawls ${ }^{8}$ para

8 Conforme Assumpção e Araújo, a resistência ao liberalismo político na academia brasileira gerou bastante resistência à recepção da obra de John Rawls que no mundo todo já pautava os debates no campo da filosofia e teoria política e no direito. A inserção de intelectuais brasileiros nessa discussão tardou a acontecer e, quando finalmente ocorreu, teve de se dar via seu debate com Habermas no Journal of Philosophy, em 1995. Assim, afirmam os autores, "Vê-se com clareza, por esse acontecimento, como a teoria crítica, em solo brasileiro, não só empresta seu prestígio para enraizar a perspectiva normativa da Teoria Política, mas também contribui decisivamente para fixar o campo temático principal da reflexão e do debate". (ARAÚJO;ASSUMPÇÃO, 2010, p. 60) 
o Brasil, ganhará centralidade na academia brasileira, especialmente na área da teoria política, da filosofia política e do direito, no fim da década de 1990 e início dos anos 2000. (ARAÚJO; ASSUMPÇÃO, 2010)

Desse mesmo comboio, desembarcam o debate liberais-comunitaristas, a obra de Axel Honneth, e as teorias críticas feministas. A essa altura, a primeira geração desta última vertente já havia formulado suas próprias teses em intensos debates entre si e com Honneth e Habermas. No entanto, no Brasil, as autoras feministas foram, inicialmente, apresentadas como comentadoras secundárias dos grandes nomes da teoria crítica, e nem sempre identificadas com o feminismo. As razões disso são muitas; no entanto, não acho que seja o caso de avançar nessa análise sem apoio em uma pesquisa minuciosa sobre a recepção da teoria crítica feminista no Brasil, que, como é muito recente, está ainda à espera de estudos sociológicos que a tomem por objeto.

De qualquer modo, o que me parece que se pode afirmar com mais segurança é que a teoria crítica feminista no Brasil cresce juntamente com uma demanda por reflexões sobre opressão de gênero na sociedade e na academia brasileiras. Não que essa questão não fosse objeto de pesquisas no país. Ao contrário, esse é um campo de pesquisa bastante consolidado nas áreas de sociologia, antropologia, literatura, entre outras. Mas a área da ciência política, em particular, a teoria política e a filosofia sempre se mostraram mais resistentes a essas questões. Não apenas no Brasil. O que se vê atualmente, porém, é que essa resistência está cedendo. A meu ver, é inegável que o caminho hoje está mais aberto do que nunca esteve para que a teoria crítica brasileira leve em conta as questões de gênero em seus diagnósticos e prognósticos.

\section{Principais temas da teoria crítica feminista}

O que significa levar em conta questões de gênero na teoria crítica? Qual é a constelação de temáticas e desafios epistemológicos que a apropriação feminista da teoria crítica propõe? Não existe resposta fácil, nem única para essas questões. Afinal, o próprio método da teoria crítica exige a renovação de suas temáticas e abordagens, sem a qual o diagnóstico do 
tempo presente pode tornar-se anacrônico e, desse modo, perder seu caráter crítico.

Assim, um modo menos arriscado de abordar essa questão parece ser, acompanhando a estratégia de Ferrarese (2018), a de não sucumbir à tentação de fazer uma "cartografia dos temas propostos pela primeira onda da crítica feminista" ou pela geração seguinte, restringindo-nos a distinguir temas mais gerais que ganharam predominância na reflexão dessa primeira geração. Evidentemente, essa constelação de temáticas e abordagens teóricas não delimita fixamente o campo, mas ao menos contribui para entendermos o contexto de sua consolidação.

Ferrarese (2018, p. 179, grifo do autor) destaca três grandes conjuntos temáticos na primeira geração:

[...] um pensamento sobre a natureza que permite deslocar a natureza humana, feminina e biológica para o seu lugar devido: inatingível e supérfluo; uma reflexão sobre emancipação e os paradoxos dessa busca; e, enfim uma teoria da forma de vida capitalista que oferece uma visão fecunda da articulação entre produção e reprodução.

No que se refere à relação entre natureza humana e feminina, a Escola de Frankfurt inspira a ideia de que a biologia é histórica e cultural. Certamente esse modo de compreender a relação entre natureza e cultura não é exclusiva dos frankfurtianos, mas ali está mais diretamente endereçada a questão da história “como desdobramento da razão instrumental; [...] [que] coincide com uma dominação da natureza - interna e externa - cada vez mais desenvolvida". (FERRARESE, 2018, p. 180)

Tendo essa questão em vista, Ferrarese marca a diferença entre os pontos de partida da teoria crítica feminista e outras duas vertentes feministas contemporâneas bastante influentes: o ecofeminismo e a ética do cuidado. Em ambas há uma reivindicação de especificidade do feminino que se contrapõe ao masculino. No caso do ecofeminismo, haveria uma pressuposição de relação privilegiada entre a mulher e a natureza, segundo a qual as tarefas de reprodução estimulariam uma conexão mais harmônica com o meio ambiente, “distinta da apropriação bruta do que a 
natureza produz, característica do modo de produção capitalista e colonialista”. (KAREN, 1997 apud FERRARESE, 2018, p. 181) No que se refere à ética do cuidado, o que predomina, segundo Ferrarese, é a ideia de que há uma voz feminina silenciada que precisa ser ouvida, ${ }^{9}$ que apela a uma "fidelidade a seu próprio fundamento, a uma injunção de abrir caminho para uma integridade sepultada [...]”.

A crítica radical à ideia de uma natureza primeira, que está presente desde a primeira geração da teoria crítica, aponta para um trajeto feminista que vai na direção oposta a qualquer tentativa de manter-se fiel ao feminino ou de enxergar neste último alguma espécie de valor redentor das mulheres. ${ }^{10}$ De fato, na obra das teóricas críticas, a despeito das diferenças entre elas, o que se nota é a rejeição de um feminismo que assume um compromisso exclusivo e endógeno com as mulheres. Isso se deve em grande medida ao fato de abraçarem uma concepção intersubjetivista no processo de subjetivação que não seria compatível com a possibilidade de se entender um compromisso consigo mesmo, ou entre as mulheres, sem a mediação dos outros. (FERRARESE, 2018, p. 184)

No que se refere às reflexões sobre emancipação e seus bloqueios, pode-se dizer que esse tema está no foco de todas as autoras da primeira geração, muito embora, talvez, apenas em Fraser, emancipação se aproxime de uma conotação mais marxista, associada a críticas do capitalismo. Essa questão esteve sempre em seu radar, mas parece ter ganhado destaque ainda maior em suas reflexões a partir de 2009, ${ }^{11}$ talvez em função do

9 Ferrarese faz referência ao livro de Carol Gilligan, Different Voice: psychological theory and Women's development, 1992.

10 Estou de acordo com essa distinção que Ferrarese faz entre teoria crítica e perspectivas teóricas que essencializam o feminino. No entanto, vale lembrar que não raro as teóricas críticas dialogam e até mesmo incorporam algumas dessas teses, muito embora o façam procurando salientar que se sua apropriação repousa sobre uma leitura que as esvazia de qualquer essencialismo. Talvez, na primeira geração, o caso mais notório desse tipo de leitura seja a que Seyla Benhabib faz de Carol Gilligan em Situating The Self: Gender, Community and Postmodernism in Contemporary Ethics.

11 Seu artigo "Feminismo, capitalismo e a astúcia da história", publicado originalmente em 2009 na New Left Review parece ter sido um ponto de inflexão nessa maior ênfase que a autora desde então passaria a dar à crise do capitalismo. No entanto, é preciso ressaltar que essa questão sempre esteve no horizonte da autora. A questão da redistribuição, articulada ao reconhecimento e à paridade de participação política em sua concepção de justiça estava 
impacto que a crise de 2008 nos Estados Unidos produziu em seu país e em outras partes do mundo.

Entrelaçada às críticas ao capitalismo está a terceira temática identificada por Ferrarese: a relação entre produção e reprodução. A obra mais recente de Fraser certamente é uma das referências principais aqui, que retoma Marx e Engels para explorar esse problema, seguindo um caminho já percorrido por autoras clássicas da teoria feminista, como Gayle Rubin e Simone de Beauvoir.

Esses três conjuntos de temas destacados por Ferrarese, de fato, exprimem uma boa parte das reflexões atuais na teoria crítica feminista, mas deixa de fora outras tantas, como a produção sobre democracia, justiça, reconhecimento, psicanálise e vulnerabilidade; temas que surgem em debates sobretudo com Habermas e Honneth. Além desses, vale destacar os tópicos relacionados a conflitos culturais e militares, pós-colonialismo, imigração e religião.

Nenhuma dessas questões é exclusiva da perspectiva feminista. Boa parte da teoria crítica contemporânea envolveu-se nessas discussões na tentativa de atualizar seu diagnóstico dos bloqueios à emancipação no contexto do pós-11 de setembro e do consequente arrefecimento dos entusiasmos cosmopolitas que surgiram no pós-guerra fria.

Para finalizar, é preciso ressaltar que, mesmo acrescidos esses temas àqueles sistematizados por Ferrarese, as faltas permanecem. Isso porque não se pode ter a pretensão de esgotar a temática do campo, pois, como já foi dito, é na própria realidade do tempo presente em que a teoria crítica, inclusive a feminista, garimpa seus objetos de pesquisa e propõe novos modelos críticos. E essa realidade está em constante movimento.

em grande medida tentando responder ao crescimento das demandas de reconhecimento que começavam a invisibilizar as injustiças materiais produzidas pelo capitalismo. No entanto, me parece que, até 2009, seu modo de abordar essas injustiças não dava a mesma centralidade à crise do capitalismo que se pode ver em seus artigos mais recentes. 


\section{Considerações finais}

A relação entre teoria crítica e feminismo atualmente parece ter-se consolidado na maior parte do mundo, mas esse processo de aproximação foi bastante prolongado. Na primeira geração, talvez o filósofo mais afinado com a questão tenha sido Marcuse, ${ }^{12}$ que foi, aliás, orientador de um dos maiores ícones no feminismo negro norte-americano, Angela Davis. Mas a maior parte dos frankfurtianos, quando deu espaço às questões de gênero, o fez de modo tangencial e marginal. Mesmo Habermas, tão popular entre as feministas da primeira geração, somente garantiu maior espaço a essa questão depois de recepcionar algumas das críticas feministas que sofreu, como por exemplo, a de que a exclusão das mulheres é inseparável da constituição da esfera pública. (HABERMAS, 2014, p. 46)

Mas, se na avaliação das feministas, a teoria crítica não dava suficiente espaço às questões de gênero, o que, afinal, elas viram na Escola de Frankfurt? Por que reivindicaram e ainda hoje reivindicam essa filiação teórica? De um modo geral, acredito que se possa dizer que as filósofas da primeira geração viram o potencial de um método que lhes permite formular critérios crítico-normativos para distinguir as injustiças de gênero ancoradas na realidade. Além disso, o fato de este mesmo método ser mobilizado em reflexões sobre democracia, ética e linguagem parece ter-lhes dado o instrumental para articular, a partir de Habermas, teorias capazes de pensar a democracia problematizando a dicotomia público e privado, de pensar a relação entre o universal e o particular e de pensar a autonomia e a ação política num registro intersubjetivo e dispensando recursos metafísicos. O ponto de chegada dessas autoras, porém, leva o modelo habermasiano muito além do que ele próprio poderia antecipar ou concordar. Mas essa é justamente a estratégia mais persistente entre as teóricas críticas de primeira geração: ir com Habermas além de Habermas.

Axel Honneth, por exemplo, contemporâneo das feministas norteamericanas, enfrentou também os desafios trazidos por elas, engajandose em debates profícuos e continuados. Na geração seguinte, os debates já

12 Em 1960, H. Marcuse publicou um ensaio chamado "Marxism and Feminism." na New Left Review. Ver. Keller (2005). 
começam a se adensar. Também entre os mais jovens o que se vê é a persistência desse processo dialógico de se fazer teoria. Rainer Forst, Amy Allen, Rahel Jaeggi e Robin Celikates, por exemplo, prosseguem na produção no campo movidos por debates com seus antecessores e contemporâneos.

No Brasil, ainda é cedo para saber como a teoria crítica feminista irá se estabelecer, já que, como dito antes, só muito recentemente essa área de pesquisa começou a ganhar corpo. De qualquer modo, acredito que a relação entre feminismo e teoria crítica, tal como vem se desenvolvendo até agora no mundo, aponta para um modo de pensar o feminismo que não o setoriza como temática, nem como método, que coloca as discussões de gênero imbricadas no problema da justiça, da democracia e do reconhecimento, que dá espaço para o problema da diferença, sem perder de vista a igualdade, que denuncia exclusões sexistas com o cuidado de não legitimar práticas e discursos sectários.

Foi pela prática do diálogo com filósofas feministas de vertentes rivais e com filósofos (as) não feministas, mas que ainda assim oferecem recursos para se fazer uma teoria crítica da sociedade, que o romance (e seus inevitáveis conflitos) entre teoria crítica e feminismo começou. Para que seja durador, inovador e crítico também no Brasil, acredito que manter a receptividade e o diálogo com a diversidade epistemológica e teórica que diferentes perspectivas e campos disciplinares nos apresentam é o primeiro passo para que a nascente teoria crítica feminista brasileira cresça comprometida tanto com a orientação para a emancipação quanto com um comportamento crítico.

\section{Referências}

ADORNO, T.; HORKHEIMER, M. Dialética do esclarecimento: fragmentos filosóficos. Tradução Guido Antônio de Almeida. Rio de Janeiro: Jorge Zahar, 1985 .

ALLEN, A. Entrevista com Amy Allen. Revista do Centro de Pesquisa e Formação, São Paulo, n. 3, nov. 2016. 
ARAÚJO, C.; ASSUMPÇÃO, S. R. Teoria política no Brasil hoje. In:

MARTINS, C. B.; LESSA, R. (Org.). Horizontes das ciências sociais no Brasil: ciência política. São Paulo: Anpocs, 2010. p. 51-85.

BENHABIB, B. Situating the Self: Gender, Community and Postmodernism in Contemporary Ethics. New York: Routledge, 1992. BENHABIB, B. et al. Feminist Contentions: a philosophical Exchange. New York: Routledge, 1995.

CYFER, I.; NEVES, R. Entrevista com Nancy Fraser. In: ABREU, M. (Org.). Redistribuição, reconhecimento e participação política: diálogos sobre igualdade de gênero. Brasília, DF: IPEA, 2011.

CYFER, I. A tensão entre modernidade e pós-modernidade na crítica à exclusão no feminismo. 2009. 140 f. Tese (Doutorado Ciências Políticas) Faculdade de Filosofia, Letras e Ciências Humanas, Universidade de São Paulo, São Paulo, 2009.

FERRARESE, F. (Re)fazer a teoria crítica: por uma (re)leitura feminista. Revista Dissonâncias, [s.1.], v. 1, n. 2, 2018.

FRASER, N. False Anthitesis: a response to Seyla Benhabib and Judith Butler. In: BENHABIB, B. et al. Feminist Contentions: a philosophical Exchange. New York: Routledge, 1995.

FRASER, N. Foucault on modern power: empirical insights and normative confusions. Práxis International, Oxford, n. 3, 1981.

FREITAG, B. A teoria crítica ontem e hoje. Brasília: Brasiliense, 2004.

GONÇALVES, F. Iris Young, Nancy Fraser e Seyla Benhabib: uma disputa entre modelos críticos. In: NOBRE, M. Curso livre de teoria crítica. Campinas, SP: Papirus, 2013.

HABERMAS, J. Mudança estrutural da esfera pública. Tradução Denílson Werle. São Paulo: Editora UNESP, 2014.

HABERMAS, J. Theorie of Communicative Action: reason and the rationalization of Society. Boston: Beacon Press, 1984.

HORKHEIMER, M. Teoria tradicional e teoria crítica. São Paulo: Abril Cultural, 1989. (Os pensadores). 
MARCUSE, H. Marxism and Feminism. New Left Review. KELLER, D. (Ed.). Collected papers of Hebert Marcuse. Routledge: New York, 2005. v.3. NEVES, R. Reconhecimento, multiculturalismo e direitos: contribuições do debate feminista a uma teoria crítica da sociedade. 2005. $86 \mathrm{f}$. Dissertação (Mestrado em Ciências Políticas) - Faculdade de Filosofia, Letras e Ciências Humanas, Universidade de São Paulo, São Paulo, 2005. NICHEL, P. M. (Ed). North American Critical Theory after Postmodernism: Contemporary dialogues. New York: Palgrave: Macmillan, 2012.

NOBRE, M. A Teoria crítica. Rio de Janeiro: Zahar, 2008.

YOUNG, I. Justice and Politics of Difference. Princeton: Princeton University Press, 1990. 
2

\section{RESISTÊNCIA E OCUPAÇÃO \\ DE ESPAÇOS: debates feministas e} queer em Relações Internacionais

Janina Onuki Ana Balbachevsky Guilhon Albuquerque Arthur Murta 
Por muitos anos prevaleceu na agenda das Teorias de Relações Internacionais o debate em torno da segurança internacional e do equilíbrio de poder em um sistema internacional em que os Estados eram vistos como atores unitários, cujas ações eram delimitadas pelo poder político e, portanto, únicos influenciadores das relações internacionais.

No entanto, a evolução do campo trouxe consigo a percepção sobre a relevância de novos atores sociais num ambiente internacional marcado pela profunda interdependência econômica e política. Tal movimento pode ser verificado pela introdução de novos conceitos e abordagens, capazes de dar conta da diversidade de temáticas e de variáveis interligadas para a compreensão de fenômenos que marcam o cenário internacional nas últimas três décadas de forma mais efetiva.

Neste contexto recente, várias perguntas passaram a ser feitas no campo das Teorias de Relações Internacionais, não mais limitadas ao debate entre realistas e liberais. O debate sobre gênero, feminismo e, mais recentemente, teoria queer nas Relações Internacionais tornou-se indispensável na própria discussão sobre a sociedade internacional, conformando-se como uma nova agenda de pesquisa, que traz subsídios teóricos e nos leva a discutir a perspectiva de uma análise empírica mais diversa e consistente com a realidade internacional contemporânea.

Esse capítulo objetiva 1) apresentar as principais perguntas sobre o papel da mulher e sua atuação no cenário internacional;2) discutir como as teorias feministas foram inseridas no campo das teorias das Relações Internacionais, ocupando um lugar de destaque, questionando as teorias do mainstream - focadas na busca do equilíbrio de poder - e desafiando os campos epistemológicos e metodológicos da disciplina;3) expor as linhas gerais das contribuições da Teoria Queer para as Relações Internacionais e sua recente agenda de pesquisa.

\section{Uma nova abordagem para as Teorias de Relações Internacionais}

Nós sempre estivemos aqui, fazendo o que tinha que ser feito. Tão confiável quanto o mobiliário, tão solidário quanto a sua poltrona 
favorita [...] Estávamos sempre aqui, trabalhando, comendo, dormindo, cantando, sofrendo, dando à luz, morrendo [...] Nenhuma refeição foi preparada sem passar por nossas mãos. Nenhum dos escritórios funcionou por uma hora sem nosso atendimento, sem nosso dedo no teclado. Nem um livro que nos ignora poderia ter sido escrito sem que nós fizéssemos as compras, sem que nós costurássemos, passássemos digitássemos, preparássemos o café reconfortante. Esta é a nossa história, e a verdade de nossas vidas vai derrubá-los. ${ }^{1}$ (MORALES, 2017, p. 16)

Onde estão as mulheres nos debates de Relações Internacionais (RI)? Onde estão as acadêmicas, políticas, militares e diplomatas? Durante muito tempo, as teorias e os debates dentro da área de RI foram vistos como sendo neutros, sem a necessidade da utilização de variáveis de gênero, uma vez que o estudo das RI seria o estudo das relações interestatais. Porém, as mulheres também estão no front, exercendo os mais distintos papéis no cenário internacional. Ainda que estejam em toda a parte, por muito tempo foram esquecidas no debate acadêmico. Hoje, não mais. Nesse sentido, questiona-se: qual o papel do feminismo dentro das Relações Internacionais? Qual a crítica desta vertente sobre teorias clássicas?

A desigualdade de poder entre homens e mulheres é algo presente em todo o mundo, seja ele ocidental ou oriental, no Norte e no Sul Global. Não só a desigualdade social está presente em múltiplas culturas, como também se vê a própria discussão acerca da dominação patriarcal, que pode ser encontrada em diversos momentos históricos, perpassando períodos de maior ou menor opressão e controle. (MIGUEL; BIROLI, 2015, p. 18) Levando em conta a ideia de que a variável do patriarcado (ou

1 "We have always been here, doing what had to be done. As reliable as furniture, as supportive as their favorite sillón [...] We were always here, working, eating, sleeping, singing, suffering, giving birth, dying [...] Not one meal was ever eaten without our hand on the pot. Not one office ran for an hour without our ear on the phone, our finger on the keyboard. Not one book that ignore us could have been written without our shopping, baking, mending, ironing, typing, making coffee, comforting. This is our story, and the truth of our lives will overthrow them." 
dominação masculina ${ }^{2}$ ) pode ser considerada uma constante em diversas sociedades, não é difícil entender a teoria política feminista como uma epistemologia possível dentro dos debates das Relações Internacionais, preenchendo lacunas e trazendo novos questionamentos às agendas de pesquisa.

\section{O fim de uma era}

Após a Segunda Guerra Mundial, o mundo passou por um período longo em que duas nações dominavam o sistema internacional, em um sistema bipolar de superpotências. Durante a Guerra Fria, uma das teorias dominantes e mais aceitas entre pesquisadores era o Realismo e seus desdobramentos, em que teóricos como Hans Morgenthau acreditavam que era da natureza dos homens, e por isso dos Estados, dominar outros, o que levava, inevitavelmente, à guerra. (WALT, 1998) Waltz, a partir da teoria neorrealista, destaca não mais a natureza humana, mas o contexto em que se encontram os Estados como componente indispensável de análise. Assim, o sistema internacional anárquico traria incerteza quanto à segurança estatal e, por isso, tendia à guerra e a violência. (WALTZ, 2001)

Em meados dos anos 1970, o aprofundamento das relações financeiras e econômicas entre Estados deu espaço para que outras teorias entrassem no debate de RI. O neoliberalismo (ou neo-institucionalismo) 3 já trazia a importância de Instituições para a análise das Relações Internacionais, assim como o aumento da dependência financeira entre Estados, que seria visto como um impeditivo ou, pelo menos, uma dissuasão à guerra. O aumento do número de Estados participantes da Organização das

2 Luis Felipe Miguel, no primeiro capítulo do livro que escreveu em conjunto com Flávia Biroli, traz a discussão sobre as controvérsias acerca do uso do termo patriarcado ou dominação masculina, que podem ser definidas como padrões de opressão em um sistema hierárquico baseado na dualidade do gênero, onde o público e privado são esferas separadas e relações privadas são despolitizadas. Para mais informações: Miguel e Biroli, (2015. p. 12).

3 Neo-Institucionalistas como Joseph Nye, trouxeram à tona conceitos como Soft e Hard Power, e tentam mostrar que não é apenas de poder "duro" que são feitas as relações internacionais, mas também com influência cultural e diplomática, assim como negociações e coalizões por meio de instituições. Para mais informações: Nye Jr (2009, p. 160-163). 
Nações Unidas (ONU) ${ }^{4}$ e a criação de novas instituições, como o Banco Mundial, o Fundo Monetário Internacional (FMI) e a consolidação do Acordo Geral de Tarifas e Comércio (GATT), posteriormente abarcado pela Organização Mundial do Comércio (OMC) quando criada em 1995, fizeram com que o debate neo-neo ${ }^{5}$ se tornasse por muito tempo o centro da disciplina e de estudo, especialmente nos Estados Unidos.

No início dos anos 1990, com o fim da Guerra Fria, o debate acadêmico de Relações Internacionais se ampliou expressivamente nos âmbitos ontológicos, epistemológicos e metodológicos. Para além das contribuições e críticas construtivistas - uma das perspectivas mais aclamadas nesse período -, ganharam força outras, que desafiavam teóricos a sair do debate centralizado em grandes potências e olhar para o Sul Global com mais afinco. Também se fortaleceram as análises que buscavam compreender várias outras dinâmicas, contemplando relações locais, e não apenas estatais.

Nesse período, ganhou ânimo o emergente debate que envolvia teóricas feministas e de Relações Internacionais sobre uma nova maneira de enxergar a disciplina, a política e economia mundial. Em seu prefácio para o livro Gendering World Politics, J. Ann Tickner “comemora” o fato de que desde a década de 1970 estes questionamentos começavam a aparecer e, hoje, devido a um grande esforço de acadêmicas ao redor do mundo, os debates vêm ganhando força e têm se tornado cada vez mais indispensáveis em congressos e salas de aula.

A ascensão do olhar feminista nos estudos de RI se deve a diversas mudanças na política mundial que se consolidaram com o fim da Guerra Fria e aos avanços no campo de direitos. O declínio da probabilidade de um conflito entre dois superpoderes e o aumento da participação de atores não estatais nas relações internacionais, fizeram com que houvesse espaço para novos campos de interesse, em que "previamente a

4 Para mais informações sobre quais países aderiram e quando aderiram, olhar: ONUBR. Países membros. Disponível em <https://nacoesunidas.org/conheca/paises-membros/> Acesso em: 7 maio 2018.

5 Debate entre teóricos adeptos ao Neorrealismo e ao Neoliberalismo nas Relações Internacionais, que ficou conhecido como debate neo-neo. 
atenção era voltada à rivalidade do Leste com Oeste, uma variedade de tópicos hoje em dia ocupa a agenda de estudos de segurança das Relações Internacionais" (TICKNER, 2001, p.1), dentre elas as questões de gênero.

Dessa maneira, é equivocado sustentar que a disciplina de Relações Internacionais seria neutra, visto que se insere em uma dinâmica global baseada em uma dualidade de gênero para sua organização. Teóricas feministas definem gênero como características que, apesar de variarem em tempo e lugar, são cultural e socialmente construídas, como, por exemplo: poder, autonomia e racionalidade (características masculinas) e fraqueza, dependência e emoções (características femininas). (TICKNER, 1997) Além disso, estruturas de gênero são, inevitavelmente, relações de poder. (SCOTT, 1986) A seguir, analisar-se-á como o feminismo colidiu com as Relações Internacionais, suas contribuições e os principais debates entre teóricos e teóricas sobre conceitos básicos como poder e segurança.

\section{Desentendimentos}

As tensões entre feministas e teorias clássicas de RI também se dão pelo fato de que, no período após a Segunda Guerra Mundial, teóricos da disciplina buscaram fomentar análises sistêmicas e orientadas para o Estado, enquanto as teorias críticas e feministas utilizam a mulher como sujeito na disciplina e o gênero como categoria de análise. As teóricas feministas têm prezado por um pluralismo epistemológico, bem como com certas sensibilidades ontológicas (TICKNER, 1997), aproximando-se do que ficou conhecido como o terceiro debate (WAEVER, 1996), ou "pós-positivismo".

Mary Wollstonecraft - considerada por muitos como uma das fundadoras do feminismo (MIGUEL; BIROLI, 2015) - contestava, em sua obra de 1792, “O direito divino dos maridos" (WOLLSTONECRAFT, 1978), que a independência da mulher por meio da educação e o direito ao voto traziam a ideia de que a mulher deveria ser livre para ser seu melhor e, assim, igualar-se intelectualmente a seu marido, podendo desta forma possuir seu próprio dinheiro e propriedade. A luta pelo sufrágio dura até os dias 
de hoje. ${ }^{6}$ Porém, o feminismo liberal de Wollstonecraft recebeu - e recebe - fortes críticas por ter um viés de classe (e, por consequência, de raça).

Em seu famoso discurso “Ain’t I a Woman?”, Sojourner Thruth, negra e escrava liberta, questiona não ser contemplada na discussão acerca do feminismo e direitos da mulher, nem pelos homens, que não a tratam como mulher, nem pelas mulheres, que são incapazes de perceber essas diferenças entre elas próprias. (STOWE, 1863) O fato é que a mulher branca de classe média-alta dos Estados Unidos e da Europa não ocupava o espaço público de trabalho. Porém, uma grande parcela da população feminina (operária e ex-escrava) já trabalhava lado a lado com homens há muito tempo. ${ }^{7}$ Além disso, no início do século XIX, o feminismo marxista tentava trazer a mulher operária para o centro de sua discussão. ${ }^{8}$ De um modo geral, diferentes vertentes feministas tentam ilustrar e explicar a subordinação feminina e sua relação - injustificável - de assimetria social e econômica para com os homens. (TICKNER, 2001)

Uma das primeiras reformulações das Relações Internacionais de um ponto de vista feminista foi feito por Tickner em 1988 em seu artigo "Hans Morgenthau's principles of political realism: A feminist reformulation”. Nele, a autora chama a atenção para o fato de que existem características que são atribuídas à dualidade de gênero, como razão (masculina) e emoção (feminina). Ressalta ainda que as características atribuídas à masculinidade são, em geral, mais valorizadas tanto por homens quanto por mulheres. (TICKNER, 1988) Um exemplo de como isso transbordaria para o pensamento em RI está na teoria realista de Hans Morgenthau, que

6 A Arábia Saudita era o último país a negar o voto a mulheres, onde elas votaram em 2015 pela primeira vez: G1MUNDO. Mulheres votam pela primeira vez em eleições na Arábia Saudita. Disponível em <http://g1.globo.com/mundo/noticia/2015/12/mulheres-votam-pela-primeiravez-em-eleicoes-na-arabia-saudita.html>. Acesso em: 10 maio 2018.

7 É importante frisar o quanto a discussão acerca esfera pública e privada é densa dentro da teoria política feminista. Segundo Flávia Biroli, a crítica sobre a divisão entre as esferas públicas e privadas e a garantia da liberdade e real autonomia das mulheres depende da politização de aspectos relevantes da esfera privada. Para mais aprofundamento nesta discussão, recomendo a leitura de Miguel e Biroli (2015, p. 29).

8 Apesar da leitura de Marx e Engels ser de que o patriarcado se estabelece apoiado na lógica capitalista, eles defenderam em seus textos a igualdades entre homens e mulheres. Algumas autoras que teceram teses e argumentos sobre autonomia da mulher comunista e socialista foram: Alexandra Kollontai (1872-1952) e Clara Zetkin (1857-1933). 
é altamente baseada em um vocabulário masculinizado (poder, racional, guerra, Estado etc.), o que reforçaria a ideia de que sua teoria é racional (ou seja, não-emocional).

O mesmo processo se observa no conceito de poder na teoria realista, que, como mencionado anteriormente, está ligado à dominação de um homem sobre o outro. Nesse sentido, o poder na política foi (e ainda é) atribuído ao homem, e não à mulher. Pode-se verificar tal construção ao se observar que, ao longo da história, raras foram as rainhas e, ainda hoje, raras são as chefes de Estado.

Para explicar o conceito de poder, as mulheres em geral usam uma definição distinta da de Morgenthau. Jane Jaquette (1984), uma das autoras citadas por Tickner para explicar o poder feminino em contraste ao poder masculino, argumenta que as mulheres em geral dependem da persuasão em lugar da coerção. Ou seja, o conceito de poder, quando ligado à mulher, estaria muito mais relacionado à coalizão e à mútua-capacitação. ${ }^{9}$ A releitura de conceitos, antes dados como certos dentro da disciplina, pode ser considerada como o primeiro esforço de feministas para uma contribuição mais ampla em Relações Internacionais.

Em 1989, o artigo intitulado "International Relations Theory: Contribution of a Feminist Standpoint”, de Robert Keohane, dá início a um debate entre teóricas feministas e autores da escola clássica de Relações Internacionais. Em resposta a Christine Silvester, ${ }^{10}$ Keohane traz o argumento de que, apesar das críticas pós-modernistas, a concepção de um ponto de vista feminista promoveria um começo interessante para uma teoria feminista de Relações Internacionais. O debate ${ }^{11}$ ficou famoso, pois, de acordo com Tickner (2001), o engajamento entre feministas

9 A autora utiliza o termo "mutual-enablement”, capacitação-mutua é tradução livre nossa.

10 Christine Sylvester é professora de ciências políticas e estudos sobre mulheres na UConn (Universidade de Connecticut) e é afiliada à Escola de Estudos Globais da Universidade de Gotemburgo, na Suécia. Sua contribuição nos estudos de feminismo e relações internacionais é extensa. Um livro importante para a área: Feminist International Relations: An Unfinished Journey (2002).

11 Aqui não vamos mencionar todas as respostas e contra-respostas dentro do amplo debate que existe até os dias de hoje. Algumas das principais contribuições e inserções de autoras e autores das Relações Internacionais são mencionados afim de termos uma ideia das principais causas de desentendimentos entre as feministas e teóricos clássicos de RI. 
e pesquisadores mais convencionais das RI é raro. Além disso, o debate apresenta quais são os principais pontos de críticas feministas dentro das teorias clássicas e como foi a resposta recebida dentro do campo.

Cynthia Weber (1994), em resposta ao artigo de Keohane, mostra justamente as problemáticas do que ela chama de "male paranoia" (paranoia masculina) em momentos em que homens são confrontados com a possibilidade de perder o perímetro de sua atuação e tentam, de certo modo, fazer com que as críticas estejam dentro deste perímetro, ou de um novo delimitado por si mesmos. Aqui é importante notar que, apesar de sua intenção ser de incentivar um "ponto de partida promissor para o desenvolvimento de uma teoria feminista internacional" (KEOHANE, 1989), o texto, de acordo com Weber, é limitador ao tentar fazer com que a teoria crítica entre em conformidade com a norma.

Francis Fukuyama (1998) começa sua crítica às teóricas feministas em Relações Internacionais ao analisar atividades e relações entre primatas. Sua analogia é que, biologicamente, o macho é mais violento que a fêmea. Ele chega a afirmar que "um mundo conduzido por mulheres seguiria regras diferentes e que as sociedades pós-industriais e ocidentais estariam caminhando em direção a este tipo de mundo. Com as mulheres ganhando poder nestes países, estes se tornariam menos agressivos, aventurosos, competitivos e agressivos". Portanto, para o autor, o problema das teóricas feministas estaria no fato de que elas "veem estas atitudes em direção à violência, poder e status como completamente os produtos de uma cultura patriarcal, enquanto que na verdade parece que eles estão baseados na biologia”. Esta não seria a primeira vez que o feminismo lidaria com questões existencialistas e biológicas como variável explicativa do sistema patriarcal. A famosa obra de Simone Beauvoir (2014) possui traços deterministas sobre a condição da mulher, culpando em parte a fisionomia do sexo feminino pela subordinação patriarcal.

Ressalta-se que o pensamento determinista é bastante perigoso por reduzir o papel da mulher como uma distinção meramente biológica, deixando de fora a importância dos papeis sociais e dando um fim às críticas à hierarquia de gênero na sociedade. Em uma resposta a Fukuyama, Barbara Ehrenreich frisa que a guerra é complicada demais e deriva de 
ações coletivas, não devendo ser explicada pelo impulso de um homem. Para a autora, "é um grande passo, do que pode ser uma tendência biologicamente inata para a agressão individual à guerra de grupo ritualizada, socialmente sancionada e institucionalizada"12(EHREINRECH; KATHA, 1999)

Ainda neste debate, Adam Jones (1996) argumenta que "tentativas feministas de lidar com as variáveis de gênero permanecem limitadas, ou mesmo radicalmente restringidas". Em seu artigo "Does Gender make the World go round?", o autor sustenta que "O sucesso das feministas em explorar a variável gênero permanece, neste ponto, misturado. E até que as estruturas feministas sejam expandidas e, até certo ponto, retrabalhadas, é difícil ver como uma teoria persuasiva ou um relato da diferenciação de gêneros das relações internacionais pode ser construído.”13 (JONES, 1996, p. 420)

Jones busca trazer uma contribuição para a discussão e critica o fato de que a utilização da variável "gênero", em estudos feministas, é automaticamente direcionada à mulher, e nunca ao homem. Ele aponta diversos casos, como os tumultos anti-sikh de 1984 em Nova Delhi, em que cita Madhu Kishwar (1985) afirmando que "tem havido poucos casos de mulheres sendo mortas, exceto quando ficaram presas em casas que foram incendiadas. Quase todas as mulheres entrevistadas descreveram como homens e meninos eram alvos especiais". ${ }^{14}$ Em suma, Jones insiste que estudos de gênero não se confundam com estudos de mulheres, pois vê isso como uma possível limitação a uma teoria feminista de relações internacionais.

12 "it is a large step from what may be biologically innate leanings toward individual aggression to ritualized, socially sanctioned, institutionalized group warfare".

13 '"feminists' success in exploring the gender variable remains, at this point, mixed. And until feminist frameworks are expanded and to some extent reworked, it is hard to see how a persuasive theory or account of the gendering of international relations can be constructed." (JONES, 1996, p. 420)

14 "there have been very few cases of women being killed except when they got trapped in houses which were set on fire. Almost all the women interviewed described how men and young boys were special targets" 
O que se nota pelo argumento de Jones é que o autor, assim como outros dentro da disciplina, ainda não entende o que significa utilizar o gênero como categoria de análise dentro de estudos de política internacional. Em seu artigo intitulado "Você ainda não entende: por que continuam existindo divergências entre feministas e a EPI crítica", ${ }^{15}$ Giorgina Waylen (2006, p. 148) afirma ainda haver desentendimentos acerca deste tópico:

Eles (pesquisadores de RI e EPI) parecem acreditar que é suficiente fazer algumas menções às mulheres como um grupo em alguns contextos, muitas vezes como ativistas nos movimentos feministas ou em termos do impacto de um processo nas mulheres. Isso não é mais do que uma 'adição de mulheres' às análises existentes sem alterar as categorias e estruturas subjacentes. Não é ver o gênero como fundamentalmente constitutivo de processos importantes. De fato, mesmo quando as mulheres são mencionadas, muitos estudos veem as mulheres como um grupo muitas vezes inteiramente homogêneo, sem reconhecer que outros grupos são de gênero. ${ }^{16}$

Olhar para a mulher nas Relações Internacionais é importante para entender possíveis relações de poder que não são levadas em consideração em uma análise puramente institucional e estatal. Porém, assim como Waylen (2006, p. 164) afirma, significa também entender que existem vivências e experiências que não podem ser homogeneizadas, como trabalhadores de determinados setores da economia, pois este tipo de análise deixa de lado relações informais de poder e enfocam, principalmente, questões formais e contratuais.

15 “You still don't understand: why troubled engagements continue between feminists and (critical) IPE"

16 "They (IR and IPE Scholars) appear to believe that it is enough to make some mention of women as a group in a few contexts, often as activists in women's movements or in terms of the impact of a process on women. This is no more than a limited 'adding women in' to existing analyses without changing any underlying categories and frameworks. It is not to see gender as fundamentally constitutive of important processes. Indeed even when women are mentioned, many studies see women as an often entirely homogenous group, without recognising that other groups are gendered". 
Por fim, J. Ann Tickner busca entender o porquê dos desentendimentos entre teóricos clássicos das Relações Internacionais e as críticas feministas em seu trabalho "You just don't understand", de 1997.17 A autora lamenta a falta de debates públicos sobre o assunto, sendo as discussões confinadas a artigos e marginalizadas pela maioria de outros autores clássicos, além de citar situações desconcertantes em que as perguntas de homens ${ }^{18}$ (ou mulheres) em seminários se repetem e ecoam ignorância sobre o assunto:

O que essa conversa tem a ver com a solução de problemas do 'mundo real', como a Bósnia, a Irlanda do Norte ou a proliferação nuclear? Por que o gênero tem algo a ver com explicar o comportamento dos estados no sistema internacional? Não é uma disciplina neutra de gênero? Mais inquietantes são os comentários sugerindo que a apresentação é pessoalmente insultante para o público, ou que o material é mais adequado para leitura à beira do leito do que para discussões acadêmicas sérias. ${ }^{19}$ (TICKNER, 1997, p. 612, tradução nossa)

\section{Perspectivas feministas em relações internacionais}

Para começar a entender o gênero como um ângulo para o entendimento da vida social, é importante trazer à tona os questionamentos sobre o privado e o público. A diferenciação entre a vida pública e a vida privada serve, entre outras coisas, para a perpetuação de relações assimétricas de

17 A autora usa a palavra misunderstandings para explicar os desentendimentos entre teóricos clássicos de Relações Internacionais e teóricas feministas. "Desentendimentos" é tradução livre nossa do termo.

18 Não são apenas homens que criticam teóricas feministas e não são apenas mulheres que utilizam o feminismo para explicar as relações internacionais, porém é importante frisar que a grande maioria de autores clássicos (se não todos) são homens, e é com eles o debate principal dos anos 1990 que traçamos durante o texto.

19 What does this talk have to do with solving 'real-world' problems such as Bosnia, Northern Ireland or nuclear proliferation? Why does gender have anything to do with explaining the behavior of states in the international system? Isn't IR a gender-neutral discipline? More unsettling are comments suggesting that the presentation is personally insulting to the audience, or that the material is more suitable for bedside reading than for serious scholarly discussion. (TICKNER, 1997, p. 612) 
poder entre homens e mulheres. Carol Pateman (2014), em "O contrato sexual”, discute essa dualidade entre público e privado, mostrando como em um contrato - mesmo aquele de relações amorosas - é possível enxergar desigualdades: quem ganha o quê. Quando em uma dualidade algo é tratado como "privado", este perde a conotação política, ou seja, “é uma forma de isolar a política das relações de poder na vida cotidiana, negando ou desinflando o caráter político e conflitivo das relações de trabalho e das relações familiares". (MIGUEL; BIROLI, 2015) Desta forma, é possível perceber que a maneira como o poder funciona nas relações familiares é crucial para entender como ele funciona na sociedade.

Para além disso, de acordo com Cynthia Enloe, existem experiências internacionais femininas que se transpõem, o próprio Estado depende de relações pessoais para seu funcionamento. Assim, não existem relações diplomáticas, militares ou econômicas sem a presença feminina. Entretanto, na medida em que as ações masculinas são dignificadas, a feminilidade é vista como sacrifício. (ENLOE, 1989) O pensamento de Enloe explicita quão grandes são as lacunas existentes na disciplina e quão negligenciadas foram ao longo da história as relações patriarcais de poder.

Questões relevantes para o mundo real?

Como se pode perceber ao longo do texto, os questionamentos a trabalhos feministas são recorrentes e grande parte do debate estaria na pergunta "como uma perspectiva feminista pode ser capaz de responder questões relevantes do mundo real (real-world issues)?”. Nesse sentido, Tickner (1997) questiona a construção da pergunta, ao confrontar com o questionamento do que seriam "questões relevantes". Para a autora, quando esse tipo de questionamento é feito, estamos querendo dizer que estas questões proeminentes estão dadas como certas e que qualquer outra questão (que fuja de temas de hard power, como a proliferação de armas nucleares, segurança estatal, entre outras) não seria relevante. 


\section{As contribuições da teoria Queer para as relações internacionais}

Historicamente, o campo das RI negligenciou o papel da identidade de gênero e da orientação sexual como elementos centrais de análise. Contudo, as epistemologias trazidas pela teoria feminista e pela teoria queer, conforme mencionadas anteriormente, deram margem a que novas agendas de pesquisa se desenhassem nesse sentido.

Para as Relações Internacionais Queer, o gênero e as sexualidades foram centrais na formação do discurso neoliberal vigente em âmbito internacional. Sob a égide da heteronormatividade, tal discurso leva consigo valores, políticas e práticas tácitas das formas dominantes de masculinidade heterossexual. Incluindo tais variáveis como fulcrais na análise, observa-se que contradições históricas nos padrões econômicos e nas complexas estruturas do capitalismo global contemporâneo ganham uma "nova" compreensão.

Ao contrário do que se imagina, esse campo de estudo não é exatamente novo. Desde meados dos anos 1990, autoras e autores como Hagen, Peterson, Rao, Richter-Montpetit, Smith e Weber vêm se debruçando para entender como normatividades e não-normatividades relacionadas às categorias de gênero e sexualidade sustentam e contestam estruturas internacionais de poder que, por sua vez, estão diretamente ligadas às noções de heteronormatividade, homonormatividade e cisnormatividade. A partir desse ponto, a agenda de pesquisa das RI Queer contempla análises que buscam entender a formação do Estado e suas políticas, da construção de nações e nacionalismos, de estudos de Segurança Internacional e da Economia Política Internacional.

Contudo, por se tratar de um campo que ganhou maior tração nos últimos 20 anos, ainda desperta muitas inquietações e está permeado por questionamentos. Costumeiramente, o primeiro deles diz respeito ao significado da palavra queer e da manutenção do termo em inglês mesmo quando trabalhado no Brasil. Há controvérsias sobre sua origem e sobre quando o termo foi atrelado à comunidade gay de maneira pejorativa. Queer pode ser entendido como algo que é "estranho", “errado" 
ou "impróprio". Durante os anos 1980, quando a teoria Queer começou a ganhar força nas ciências sociais, a terminologia servia como forma de resistência e de um processo de ressignificação, passando de um termo pejorativo para algo positivo e que trouxesse representatividade à comunidade LGBTIQ.

Nas bases da teoria queer, influenciada em grande medida pela obra de Foucault, busca-se desafiar todas as normas em torno de gênero e de sexualidade, no pensar e no agir. Para as Relações Internacionais, o queer é entendido como verbo (Queering International Relations), ou seja, busca ressignificar todas as compreensões anteriormente estabelecidas sobre o funcionamento dos processos globais. Um exemplo desse processo de ressiginificação é trazido por Kahan (2017) ao defender a existência de um Sistema-Mundo Sexual. Ao fazer uma releitura do trabalho clássico de Wallerstein (2011), Kahan acredita que há um modelo mundial que denomina a produção, transmissão, difusão e consumo do conhecimento sexual em âmbito internacional, regional e local.

O Queer busca, portanto, desestabilizar as RI, desafiando a compreensão de gênero e de sexualidade, a partir do questionamento do que é normal. Pode-se, sinteticamente, dizer que as Relações Internacionais Queer buscam realizar análises políticas do funcionamento de normas, práticas, relações e/ou instituições sexuais e de gênero não normativas, ao mesmo tempo que se recusam a se limitar a um objeto de referência vinculado. Essa recusa busca reafirmar que o Queer não é um instrumento de análise apenas do papel das pessoas LGBTIQ nas dinâmicas internacionais, mas de todos os atores que desafiam os "regimes do normal" sexual - nacional e transnacional. Nesse sentido, inclui ainda em sua pauta temas heterossexuais não normativos, a exemplo da figura do terrorista/insurgente muçulmano.

Por fim, de acordo com Cynthia Weber e Melanie Richter-Montpetit (2017), algumas das questões centrais desse campo giram em torno de como as ideias culturais sobre gênero e sexualidade moldam a política externa e as operações militares; de quão grandemente os quadros heteronormativos, homonormativos e cisnormativos determinam as operações da economia política global; de que maneira os entendimentos 
não normativos de gênero e sexualidade se cruzam com a compreensão da diferença racial e formas coloniais de poder para construir figuras internacionalmente perigosas - como "o terrorista" ou "o insurgente" -; e do quanto os processos de formação do Estado moderno estão ligados às relações familiares heteropatriarcais e às normatividades associadas a sexualidade e gênero.

\section{Considerações finais}

As epistemologias feministas e queer trouxeram um enorme avanço do debate acadêmico de Relações Internacionais, trazendo o debate de gênero para o centro da análise das estruturas internacionais de poder. Como sustenta Angela Davis (2008), a primeira grande clivagem da humanidade foi a escravização da mulher pelo homem, de modo que todas as formas subsequentes de dominação são descendentes desta. Sendo assim, o capitalismo, o imperialismo e o racismo são sintomas da supremacia/ sexismo masculina e a posição histórica da mulher é indissolúvel da consolidação do capitalismo.

Nesse sentido, pontos levantados e estudados por feministas em Relações Internacionais não foram vistos como relevantes. O questionamento “Onde estão as mulheres?” ${ }^{\circ}$ ainda é um ponto de partida para uma análise feminista sobre o sistema internacional, de maneira que

Olhar para cima possibilita a investigação de como as estruturas de poder político e [...] econômico são criadas, sustentadas e legitimadas. [...] Olhar para baixo envolve investigações baseadas na vida daqueles que normalmente não são considerados porta-

20 Ecoando o começo do capitulo: Onde estão as mulheres nos estudos clássicos de relações internacionais? Ann Tickner, em diversos textos levanta este questionamento. Em seu livro de 2001: Gendering World Politics, a autora mostra como este pode ser um dos pontos de partida para análises de sistema de poder e relações econômicas nas relações internacionais. Não por mulheres serem mais importantes que homens, mas sim pois suas vivencias e experiências são continuamente apagadas da história e principalmente negligenciadas em análises empíricas e clássicas. 
dores de conhecimento. [in] ... 'Mais baixo que baixa política'21 (TICKNER, 2001, tradução nossa)

Trata-se de um campo em franca expansão e com muitas possibilidades de exploração teórica e empírica.

No que tange às Relações Internacionais Queer, investiga-se como certas normatividades e assuntos sexuais são produzidos e passam a ser entendidos em termos binários, questionando os efeitos políticos deste tipo de pensamento e/ou os "regimes do normal". O campo ainda tem estendido uma crítica às dicotomias heterossexuais/homossexuais e masculinas/ femininas, o que acaba por subscrever os tradicionais estudos LGBT e de gênero, incluindo algumas perspectivas LGBT e feminista em RI.

Os desdobramentos e questionamentos de gênero nas Relações Internacionais trazem à luz um debate lúcido sobre como instituições, Estados e a economia dependem de relações pessoais, que, por muitas vezes, são deslegitimadas e despolitizadas no debate clássico. O avanço da disciplina com as contribuições feministas, queer, pós-coloniais e decoloniais aponta a robustez e o potencial da disciplina, além da diversidade de desdobramentos que as agendas de Relações Internacionais ainda podem trazer.

\section{Referências}

BEAUVOIR, S. de. O segundo sexo. Rio de Janeiro: Nova Fronteira, 2014. DAVIS, A. Women and Capitalism: Dialectics of Oppression and Liberation. In: JAMES, Joy (Ed.). The Angela Y. Davis Reader. Oxford: Blackwell, 2008. p. 161-192.

EHREINRECH, B.; KATHA, P. So what if women ruled the world. Foreign Affairs, Washington, DC, v. 78, n. 1, p. 118-129, 1999.

ENLOE, C. Bananas, beaches and bases. London: Pandora Press, 1989.

21 "looking up enables the investigation of how power structures of political and economic power [...] are created, upheld, and legitimated [...] Looking down involves investigations based on the lives of those not normally considered as bearers of knowledge ...[in]... 'Lower than low politics"'. 
FUKUYAMA, F. Women and the evolution of world politics. Foreign Affairs, Washington, DC, v. 77, n. 5, p. 24-40, 1998.

JONES, A. Does 'gender'make the world go round? Feminist critiques of international relations. Review of International Studies, New York, v. 22, p. 4, p. 405-429, 1996.

KAHAN, B. Conjectures on the Sexual World-System. GLQ: A Journal of Lesbian and Gay Studies, Durham, v. 23, n. 3, p. 327-357, 2017.

KEOHANE, R. O. International relations theory: Contributions of a feminist standpoint. Millennium, [s.1.], v. 18, n. 2, p. 245-253, 1989. KISHWAR, M. Delhi: Gangster Rule. In: SINGH, P.; MALIK, H. (Ed.). Punjab: The Fatal Miscalculation. New Delhi: Patwant Singh, 1985. p. 171-178.

MIGUEL, L. F.; BIROLI, F. Feminismo e política. São Paulo: Boitempo, 2015. NYE JR, J. S. Get smart: Combining hard and soft power. Foreign affairs, Washington, DC, v. 88, n. 4, p. 160-163, 2009.

PATEMAN, C. Sexual contract. New Jersey: John Wiley \& Sons, 2014 STOWE, H. B. Sojourner Truth, The Libyan Sibyl. The Atlantic, Apr. 1868. TICKNER, J. A. You just don't understand: troubled engagements between feminists and IR theorists. International Studies Quarterly, v. 41, n. 4, p. 611-632, 1997.

TICKNER, J. A. Gendering world politics: Issues and approaches in the post-Cold War era. Columbia University Press, 2001.

WALLERSTEIN, I. The modern world-system I: Capitalist agriculture and the origins of the European world-economy in the sixteenth century. Berkeley: University of California Press, 2011.

WALT, S. M. International Relations: One World, Many Theories. Foreign Policy, New York, n. 110, Spring, 1998. Special Edition: Frontiers of Knowledge.

WALTZ, K. N. Man, the state, and war: A theoretical analysis. New York: Columbia University Press, 2001.

WAYLEN, G. You still don't understand: Why troubled engagements continue between feminists and (critical) IPE. Review of International Studies, Cambridge, v. 32, n. 1, p. 145-164, 2006. 
Parte II • Mulheres, Direitos e Instituições 


\section{3}

\section{GÊNERO E MOBILIZAÇÃO DO DIREITO NO BRASIL:}

violência e aborto, dois campos desiguais

Marta Rodriguez de Assis Machado Ana Luiza Villela de Viana Bandeira Fernanda Matsuda 


\section{Introdução}

O movimento organizado de mulheres na América Latina emergiu no final da década de 1970 no contexto de transição da ditadura e democratização. Enquanto as mulheres ingressavam cada vez mais nas universidades e no mercado de trabalho, a ideologia da família, igreja e maternidade, fortemente explorada pelos governos autoritários, era gradualmente desafiada. Ao mesmo tempo, com a agudização das desigualdades sociais, mulheres pobres se organizaram no interior de suas comunidades para melhorar suas condições de vida. Apesar de sua capacidade de mobilizar um contingente feminino expressivo, esses movimentos não eram em sua natureza exatamente feministas. Mulheres das periferias afirmavam seus direitos a melhores condições de vida sobretudo como mães e esposas. A Igreja Católica, a despeito de sua agenda social, ${ }^{1}$ não estava disposta a abandonar seu discurso tradicional sobre o papel da mulher. Embora advogasse por uma maior participação de mulheres na esfera pública e na comunidade, a igreja continuamente se opunha à igualdade sexual, ao divórcio, a medidas de contracepção, à descriminalização do aborto e à homossexualidade. A politização das condições de vida apenas intersectou a politização da maternidade e do gênero quando mulheres das classes trabalhadoras entraram em contato com ativistas brancas, de alto nível educacional e de classe média, pertencentes a grupos e organizações feministas, muitas das quais recém-chegadas do exílio. Essas mulheres deslocaram o debate para temas como igualdade no trabalho e liberdade sexual. Porém, sua ligação com mulheres pobres levou a uma mudança no ativismo feminista, que passou a ser sensível a desigualdades sociais e aos problemas que afetavam principalmente mulheres das classes trabalhadoras. Essa união entre feministas de classe média focadas na reprodução social dos papéis de gênero e mulheres pobres comprometidas com a melhoria de suas condições de vida constituiu o campo da mobilização de mulheres em vários países da América Latina - um campo ativo, diverso,

1 A Igreja Católica desempenhou um importante papel na formação desses movimentos populares em muitos países da América Latina, inclusive no Brasil, sobretudo por meio das Comunidades eclesiais de base, orientadas pela teologia da libertação. (SADER, 1988) 
complexo e não raro contraditório, em que mulheres gradualmente adentravam a política de gênero sem que o feminismo se tornasse homogêneo. Uma das contradições inerentes à origem dos feminismos latino-americanos liga-se precisamente à presença tanto de demandas feministas quanto femininas. ${ }^{2}$ (ALVAREZ, 1990) Nesse contexto, diferentes visões de mundo, discursos, categorias de gênero, direitos e políticas públicas de diversos atores coletivos interagem e competem entre si. Essa diversidade constitutiva é essencial para entender de que maneira o movimento feminista latino-americano pôde negociar com setores mais conservadores e acomodar algumas de suas mais tradicionais concepções de gênero.

Desde a transição democrática e a aprovação de novas Constituições, movimentos feministas na região têm adotado estratégias para lutar por direitos em diferentes espaços institucionais do Estado, nos níveis federal, estadual e municipal, em todos os três poderes e, ainda, no interior de órgãos internacionais. (SANTOS, 2007) Durante os anos 1990 o campo se tornou profissionalizado e internacionalizado. (ALVAREZ, 1998) Algumas feministas "históricas" assumiram papeis em instituições estatais, seja como representantes eleitas ou como conselheiras e integrantes de equipes governamentais; outras se juntaram a ONGs dedicadas ao lobby, advocacy e estratégias de litigância nacional e internacional. ${ }^{3}$

2 Neste artigo usamos movimento de mulheres e movimento feminista de forma intercambiável. Entendemos esse movimento como um campo político e socialmente heterogêneo de mobilização que engloba duas formas de politização: a mobilização de mulheres para meIhorar suas condições de vida (frequentemente aceitando a divisão tradicional de papeis de gênero e não necessariamente identificando-se como feministas) e mobilizações baseadas no questionamento dos papeis de gênero. Sonia Alvarez faz a distinção entre movimento feminino e movimento feminista. O primeiro tem demandas práticas e "tem origem em eaceita papeis predominantemente femininos e garante direitos com base nesses papeis". O segundo persegue objetivos estratégicos, como a emancipação das mulheres ou a igualdade de gênero. (ALVAREZ, 1990, p. 24-25) Maxine Molyneux (1986) também se refere à combinação de demandas práticas e estratégicas como uma característica da mobilização de mulheres na América Latina.

3 O caso Maria da Penha Maia Fernandes, apresentado pelo Centro de Justiça e Direito Internacional (CEJIL) e pelo Comitê Latino-Americano e do Caribe para a Defesa dos Direitos da Mulher (CLADEM) à Comissão Interamericana de Direitos Humanos em 1998 (assinalando a primeira vez em que a Convenção do Belém do Pará foi aplicada), e o caso Campo Algodonero sobre feminicídios no México, apresentado em 2002, são exemplos bem-sucedidos de ações feministas organizadas perante o Sistema Interamericano de Proteção dos Direitos Humanos. 
Os avanços foram desiguais: algumas demandas foram reconhecidas em Constituições ou leis específicas, outras foram traduzidas em políticas públicas, outras não progrediram ou retrocederam. A comparação entre campos de mobilização estratégica ${ }^{4}$ em torno da violência doméstica e do aborto é paradigmática porque demonstra esse avanço desigual das demandas feministas. Esses dois temas, ambos fundamentalmente importantes em relação à disputa pelo controle dos corpos das mulheres, ilustram as profundas diferenças entre as dinâmicas em jogo no que diz respeito à aceitação de discursos, à presença (ou ausência) de sinergias positivas com instituições estatais, à formação de aliados ou inimigos, bem como a sucessos, ameaças e retrocessos no que concerne aos direitos das mulheres.

Nas seções seguintes reconstruímos brevemente os processos de mobilização legal que ocorreram nesses campos no Brasil. Ao invés de tentar dar conta de todas as complexidades de cada caso, focamos nos momentos em que negociações morais foram cruciais. Dois casos que chegaram ao Supremo Tribunal Federal são analisados com maior atenção, apesar de, por razões de espaço, não termos a pretensão de esgotar as questões contextuais nesta narrativa. Para nossa análise, nos valemos dos resultados de dois diferentes projetos de pesquisa: o primeiro aborda a mobilização legal a partir da adoção da Lei Maria da Penha e da Lei do Feminicídio e sua aceitação pelos tribunais e o segundo, ainda em andamento, trata da mobilização relativa ao direito ao aborto no Brasil..$^{5}$ Em ambos os casos

4 Fazemos referência à ideia de campo sob inspiração de Flingstein e MacAdam (2011), que definem campos de ação estratégica como uma construção social intermediária em que atores individuais e/ou coletivos estão sintonizados e interagem entre si com base em compreensões compartilhadas (mas não necessariamente consensuais) sobre os propósitos do campo, relacionamentos com outros no campo (inclusive quem tem poder e por quê) e as regras que regem a ação legítima. Neste artigo entendemos que o campo de mobilização de mulheres diz respeito a condições de vida das mulheres ou questões de igualdade de gênero. A violência de gênero e o direito ao aborto constituem subcampos desse campo mais abrangente.

5 A narrativa sobre a mobilização da Lei Maria da Penha está parcialmente ancorada no projeto de pesquisa O direito visto por dentro (e por fora): a disputa pela interpretação da Lei Maria da Penha nos tribunais brasileiros, financiado pelo CNPq e coordenado por Marta Machado e José Rodrigo Rodriguez. Sobre o aborto, apresentamos aqui uma narrativa breve e parcial dos dados produzidos no bojo do projeto de pesquisa Abortion Rights Lawfare in Latin America, coordenado por Rachel Sieder (Instituto Chr. Michelsen, Noruega). 
reconstruímos processos de mobilização legal por meio de uma revisão documental secundária e de levantamento bibliográfico, além das seguintes fontes primárias: (i) minutas da Assembleia Constituinte, (ii) registros do processo legislativo da Lei Maria da Penha e da Lei do Feminicídio, (iii) decisões dos Tribunais de Justiça de nove estados referentes à implementação da Lei Maria da Penha (de setembro de 2006 a dezembro de 2010), (iv) projetos de lei a favor e contra o aborto apresentados entre 1989 e 2015, (v) duas ações julgadas pelo Supremo Tribunal Federal (STF) a respeito da constitucionalidade da Lei Maria da Penha (ADC 19 e ADI 4.424), e (vi) o caso do feto anencéfalo julgado pelo STF -incluindo a petição inicial, decisões interlocutórias, discursos na audiência pública e a sentença final.

Neste artigo sustentamos que disputas morais e processos de negociação discursiva são fundamentais para explicar as diferenças entre esses dois campos de mobilização legal. Até hoje, movimentos feministas latino-americanos tenderam a eleger o Estado como a principal arena para a ação coletiva e o confronto. (JELIN, 1987; SAFA, 1990) Como demonstramos nas seções seguintes, a capacidade de contornar, negociar ou ressignificar representações culturais dominantes sobre as mulheres, gênero e família foram cruciais para as vitórias feministas em momentos-chave da luta por mudança institucional. Concentramo-nos no movimento feminista brasileiro, mas dinâmicas comparáveis podem ser encontradas em outros países latino-americanos.

O Brasil é um importante exemplo do desenvolvimento de um ativismo feminista altamente profissionalizado que conquistou espaços relevantes dentro da burocracia estatal - esse processo teve início já em 1985, com o advento dos Conselhos Estaduais da Condição Feminina e se consolidou em 2003 com a criação da Secretaria Especial de Políticas Públicas para Mulheres durante o primeiro governo de Luiz Inácio Lula da Silva (2003-2006). Feministas adotaram estratégias de mobilização em âmbito nacional e internacional e ocuparam posições estratégicas no Poder Executivo, apesar de só terem logrado avanços em suas demandas no terreno da política pública. Da mesma forma que outros países da região, a mobilização sociojurídica nesses dois temas resultou, por um lado, 
em um alargamento da proteção contra a violência doméstica por meio da aprovação de leis e, por outro lado, em ameaças e retrocessos na esfera dos direitos sexuais e reprodutivos. (RUIBAL, 2014)

A primeira década do século XXI foi marcada por esforços em toda a região para propor leis de combate à violência contra as mulheres, com ênfase na violência doméstica. ${ }^{6}$ Em contraste, o problema do aborto não apenas enfrentou dificuldades para avançar como parte de uma agenda de direitos, mas também sofreu retrocessos em vários países. ${ }^{7}$ Numerosas Constituições latino-americanas protegem a vida "desde a concepção", incluindo aquelas de El Salvador, República Dominicana e Equador. (JURKEWICZ, 2011)

Na maioria dos países o aborto é ainda um crime, com pouquíssimas exceções, e alguns governos aprovaram recentemente legislações que vedam totalmente o aborto, até mesmo em casos de gravidez resultante de violência sexual ou diante de riscos para a vida da mulher grávida. Redes transnacionais pró-escolha e antiaborto atuam em toda a região, com atores inseridos em governos, legislaturas e tribunais. No Brasil, de modo similar aos países vizinhos, há enorme resistência na esfera pública à discussão sobre os direitos sexuais e reprodutivos das mulheres, que partem particularmente de grupos religiosos. ${ }^{8}$ No Brasil e em outros países, batalhas foram travadas em diferentes arenas do Estado para modificar e

6 Ao menos 16 países na América Latina aprovaram leis específicas para coibir a violência contra as mulheres, algumas focadas na violência "doméstica" e "intrafamiliar" (Brasil, Bolívia, El Salvador, Colômbia, Panamá, Chile, Paraguai, Honduras, Porto Rico e Uruguai) ou especificamentevoltadas paraa "violência contraas mulheres" (Argentina, Peru, Costa Rica, Guatemala, México e Venezuela). (UNITED NATIONS OFFICE ON DRUGS AND CRIME, 2011). Em março de 2015, 16 países da América Latina tinham criminalizado o feminicídio (Argentina, Bolívia, Brasil, Chile, Colômbia, Costa Rica, El Salvador, Equador, Guatemala, Honduras, México, Nicarágua, Panamá, Peru, República Dominicana e Venezuela).

7 Na América Latina, países se dividem entre aqules que permitem o aborto em caso de violência sexual e riscos para a saúde da mulher (Colômbia, Peru, Equador, Bolívia, Argentina) e aqueles que proíbem o aborto de forma absoluta (Chile, Nicarágua e El Salvador). No Uruguai e na Guiana Francesa, o aborto não é crime. (JURKEWICZ, 2011) A legislação sobre aborto no México varia de acordo com o estado da federação: a prática não constitui crime no primeiro trimestre de gestação no Distrito Federal mas ainda é crime na maior parte dos estados, com diferentes excludentes de ilicitude em cada local. (RUIBAL, 2014)

8 É o que indicam diferentes pesquisas de opinião. (CATÓLICAS PELO DIREITO DE DECIDIR, 2011; DIDES et al., 2011; FAÚNDES et al., 2013) 
ampliar as possibilidades de aborto legal. O peso das forças conservadoras, sobretudo no Legislativo, impulsionou o movimento das agendas feministas em direção aos tribunais. ${ }^{9}$ (GARCÍA PEREANEZ, 2010) A seguir, tratamos das características comuns a ambos os campos de mobilização sociojurídica com o intuito de construir hipóteses para estudos comparativos.

\section{Mobilização jurídica, enquadramentos interpretativos e políticas culturais}

Estudos sobre movimentos sociais e confronto político destacaram fatores explicativos do sucesso ou fracasso de uma ação coletiva em obter uma mudança social e institucional. Tais fatores incluem recursos, estruturas organizacionais (McCARTHY; ZALD, 1977) e performances e repertórios de ação. (McADAM; TARROW; TILLY, 2001) A estrutura de oportunidades políticas predominante (que inclui oportunidades, restrições e ameaças) explica uma parcela importante dos processos de ação coletiva, apontando para espaços institucionais mais ou menos abertos à participação da sociedade civil, bem como a propensão e a sensibilidade de agentes públicos à incorporação, negociação ou supressão de demandas. (TARROW, 1988) A habilidade de conseguir aliados dentro e fora do sistema político ou de mobilizar contramovimentos também se mostrou fundamental. Isso ocorre porque

movimentos opostos influenciam um ao outro diretamente e pela alteração no ambiente em que cada lado atua. O movimento opositor é um componente importante da estrutura de oportunidades políticas que o outro lado enfrenta. (MEYER; STAGGENBORG, 1996, p. 1633)

9 Por exemplo, a Colômbia expandiu as possibilidades de aborto legal por meio de decisão do Tribunal Constitucional em 2005, que considerou legal o aborto quando a gravidez significava risco de vida para a mulher ou era resultado de estupro. No Brasil, decisão do Supremo Tribunal Federal em 2012 também ampliou as possibilidades de aborto, como será visto adiante. 
Todos esses fatores expandem ou limitam formas de organização e ação, e são capazes de influenciar as estratégias legais dos movimentos, embora a análise do uso do direito por contramovimentos seja relativamente nova nos estudos sociojurídicos na América Latina.

Disputas simbólicas e culturais por processos de definição e interpretação da realidade têm se espraiado nos estudos sobre movimentos sociais em décadas recentes, com base no conceito de processos de enquadramento interpretativo. (SNOW et al., 2014, 1986) Movimentos sociais não apenas atuam no mundo - por meio de protestos e demandas por mudança - mas também formam enquadramentos em que há interpretação de e disputa por significados. Processos de enquadramento são contínuos e contextuais, envolvendo tentativas dos movimentos sociais opositores para ganhar legitimidade pública para suas demandas. Analiticamente, o conceito de frame consiste em que disputas políticas são inseparáveis de suas dimensões culturais; significados são constitutivos de processos que, seja implícita ou explicitamente, procuram redefinir o poder social. Isso acontece, por exemplo, quando movimentos sociais buscam significados alternativos para conceitos ou construções tais como democracia, raça, gênero, família etc. (ALVAREZ; DAGNINO; ESCOBAR, 1998, p. 7)

Enquanto o conceito de enquadramento interpretativo (framing) ganhou importância nos estudos de estratégias dos movimentos sociais, o uso de enquadramentos e as dimensões culturais das disputas são muito menos recorrentes em estudos de mobilização jurídica. Análises dos efeitos dessas acomodações ou disputas interpretativas e suas propriedades específicas no campo do direito são menos frequentes ainda. (PEDRIANA, 2006; VANHALA, 2009) Argumentamos que as dimensões culturais e morais das disputas entre movimentos sociais opostos são cruciais para a total compreensão dos processos de mobilização jurídica. Estudos a respeito do comportamento dos tribunais, de forma diversa, concentram-se na estrutura argumentativa das decisões (ALEXY, 1989; DWORKIN, 1988; GÜNTHER, 1993) e sua consistência. (MENDES, 2011; PÜSCHEL, 2014) No entanto, esses estudos nem sempre capturam os fluxos entre as instituições e a sociedade civil, que por sua vez destacam a dimensão moral em jogo em todo agumento vencedor no campo do direito. 
Da mesma forma, processos de manutenção ou mudança institucional resultante de uma ação perante os tribunais não podem ser observados em sua integralidade apenas por meio da análise de decisões e precedentes. A estabilidade de uma decisão, por exemplo, não pode ser sempre explicada por decisões pregressas e argumentos jurídicos concretos. Em alguns casos, são o escopo e a força das categorias morais e culturais dominantes que respaldam posições jurídicas.

A categoria do enquadramento desloca a atenção analítica para um espaço intermediário entre leis, morais e cultura e opera como uma categoria útil para a observação da interação entre esferas formais e informais. Demandas por direitos, respostas jurídicas e políticas públicas são sustentadas por argumentos que articulam ou assumem concepções morais e culturais, extravasando a linguagem do direito. No campo do direito, enquadramentos refletem disputas sobre modelos de regulação (formas de tratamento jurídico do problema e sua configuração no sistema jurídico), sustentadas simultaneamente por argumentos enraizados em outros tipos de legitimação: moral, científica, cultural, política e assim por diante. Enquadramentos jurídicos têm, a um só tempo, um componente institucional e sistêmico - como, por exemplo, o enquadramento de um problema em normas legais - aliado a representações simbólicas pertencentes a esferas morais e culturais.

Lutas políticas internas ao campo feminista (em arenas formais e informais) têm sua especificidade em uma intensa mobilização de representações simbólicas em torno do que sejam gênero, papel da mulher e família. Discursos e demandas feministas podem, em maior ou menor grau, desestabilizar representações dominantes. E essa dimensão é importante para a compreensão do cenário de oportunidades e dos desafios para a mobilização jurídica feminista. Algumas agendas são mais palatáveis que outras, e essa diferença guarda relação com a habilidade dos discursos feministas em acomodar, negociar ou reenquadrar as categorias morais e culturais existentes. Ao propor uma análise mais contextual, relacional e dinâmica, neste artigo utilizamos o conceito de enquadramento interpretativo para entender as disputas em jogo nos processos de judicialização das relações de gênero. 


\section{Dois subcampos da mobilização feminista em comparação: violência doméstica e aborto}

Violência doméstica e aborto são problemas que estavam presentes já na origem do movimento feminista latino-americano. Desde então, esses temas têm experimentado diferentes padrões de aceitação e rejeição. Enquanto o enfrentamento da violência doméstica se mostrou relativamente incontroverso, a questão do aborto foi rejeitada pela Igreja Católica e por militantes de esquerda que viam aí parte de uma agenda liberal que reivindicava a autonomia das mulheres e a liberdade de escolha. $\mathrm{O}$ aborto nunca foi uma prioridade entre outras demandas de mulheres que gozavam de maior consenso, como o combate à violência doméstica, a implantação de creches e a garantia da licença-maternidade e do acesso das mulheres ao mercado de trabalho. (MORAES; SORJ, 2009)

O conflito entre feministas e a Igreja Católica em torno do problema do aborto ficou bastante evidente na ocasião da elaboração da Constituição Federal de 1988. Naquele momento, feministas apresentaram a Carta da Mulher Brasileira, documento dirigido aos membros da Assembleia Constituinte que continha uma série de demandas, entre as quais o direito ao aborto. A Igreja Católica, por seu turno, pressionou a Assembleia Constituinte para que incluísse uma cláusula protegendo a vida "desde a concepção". (ROCHA, 2006) As feministas conseguiram barrar essa proposição retrógrada, mas não foi possível avançar em direção à descriminalização do aborto. De modo diverso, a violência doméstica ganhou reconhecimento institucional no início da transição democrática brasileira. A criação da primeira delegacia de polícia da mulher em São Paulo em 1985 foi um marco em termos de reconhecimento público da seriedade do problema. (SANTOS, 2005) Reclamações sobre a atuação do sistema de justiça nesses casos de violência ${ }^{10}$ e a demanda por aprovação de leis específicas para lidar com a violência de gênero foram o motivo da mobilização de mulheres durante os anos 1990 e 2000. Nesse período, essas demandas apareceram em documentos internacionais, o que trouxe

10 Pesquisas sobre delegacias de polícia da mulher apontam para a precariedade desses equipamentos e a falta de treinamento das equipes. (DEBERT; GREGORI, 2002; SANTOS, 1999) 
significativo poder de barganha. ${ }^{11}$ Casos na arena internacional alimentaram a luta pela aprovação de leis específicas contra a violência doméstica em vários países da América Latina. No Brasil, leis foram pouco a pouco sendo aprovadas nesse período, ${ }^{12}$ mas nenhuma delas ia ao encontro das reivindicações do movimento por uma estrutura legal abrangente para $\mathrm{o}$ desenvolvimento de políticas públicas inovadoras.

Em se tratando do aborto, a lei se mostrou uma fonte de oposição. Desde 1940, o Código Penal Brasileiro estabelece que o aborto é um crime e somente permite exceções a essa regra quando a mulher grávida está sob risco de morte e/ou quando a gravidez resulta de estupro. ${ }^{13}$ Apesar disso, o acesso aos serviços de aborto legal em hospitais públicos é extremamente limitado. Feministas brasileiras dividiam-se entre aquelas que advogavam pela completa descriminalização do aborto e outras que desejavam, em primeiro lugar, a garantia da implementação daquilo que já era um direito. Ao longo do tempo, a última posição, menos radical, teve maior impulso na agenda dos movimentos sociais feministas. Em termos de enquadramento, desde os estágios iniciais de mobilização relativa ao aborto, a estratégia do movimento de mulheres foi a de não focar no embate moral e na autonomia das mulheres. Na Carta das Mulheres, o problema foi colocado sob o duplo registro de gênero e saúde. O enquadramento da autonomia progressivamente desapareceu do discurso do movimento feminista e, nos anos 1990 e 2000, optou-se, integralmente, pelo enquadramento da saúde pública, focando a questão do aborto inseguro. (BARSTED, 1992)

A partir de meados dos anos 1980, feministas trabalharam para estabelecer alianças nos governos estaduais e federal, obtendo avanços em relação à regulação e implementação do aborto legal por meio da atuação do Poder Executivo. Em 1989 o primeiro hospital público a realizar o aborto legal

11 Convenção para a Eliminação de Todas as Formas de Discriminação contra a Mulher (CEDAW), de 1979, e a Convenção Interamericana para Prevenir, Punir e Erradicara Violência contra a Mulher (Belém do Pará), de 1994.

12 São exemplosa lei n. 10.778/2003 (notificação compulsória do caso de violência contra a muIher atendida em serviços de saúde públicos ou privados) e a lei n. 10.886/2004 (inclusão do crime de violência doméstica no Código Penal).

13 Artigo 128, caput, do Código Penal. 
no país foi inaugurado em São Paulo e quase dez anos depois, os primeiros protocolos técnicos regulando a prática do aborto legal foram elaborados. ${ }^{14}$ Com a maior presença do movimento de mulheres no Poder Executivo durante o primeiro governo Lula (2002-2006), ${ }^{15}$ o Ministério da Saúde expediu os (até hoje) mais avançados protocolos técnicos para o aborto legal. Vitórias feministas importantes incluíram o fim da exigência do registro de boletim de ocorrência para obter o aborto em casos de estupro ${ }^{16}$ e a previsão de que o Sistema Único de Saúde (SUS) deve fornecer serviços de aborto legal. Esforços pela implementação do aborto legal cresceram nesse período. A mobilização mais intensa culminou na participação organizada na I Conferência Nacional de Políticas para Mulheres, realizada pelo governo federal, que produziu o Plano Nacional de Políticas para Mulheres (PNPM), ${ }^{17}$ que incluiu o compromisso de "revisar a legislação punitiva que trata da interrupção voluntária da gravidez" (prioridade 3.6).

O Legislativo foi uma arena importante para a mobilização pró e contra o aborto nos anos 1990 e um espaço privilegiado para buscar a repercussão dos enquadramentos escolhidos pelo movimento social. Uma análise dos projetos de lei apresentados ao Congresso Nacional evidencia que os enquadramentos relativos à saúde pública predominaram após a promulgação da Constituição Federal de 1988. Os anos 1990 foram marcados por duas importantes conferências: a Conferência Internacional sobre População e Desenvolvimento das Nações Unidas, realizada no Cairo em 1994, e a Quarta Conferência Mundial sobre a Mulher, sediada em Pequim, em 1995.

14 Publicada em 1998, a Norma Técnica para Prevenção e Tratamento de Agravos Resultantes de Violência Sexual contra Mulheres e Adolescentes foi resultado do diálogo entre feministas e o Ministério da Saúde.

15 Além da criação da Secretaria Especial de Políticas para Mulheres, Lula nomeou uma militante feminista para encabeçar a área de saúde da mulher no Ministério da Saúde.

16 Isso resultou da Norma Técnica para Prevenção e Tratamento de Agravos Resultantes de Violência Sexual contra Mulheres e Adolescentes.

17 Conferências nacionais sobre políticas públicas foram realizadas durante o primeiro governo Lula como forma de incrementar a participação da sociedade civil na formulação da política pública. (FARIA; SILVA; LINS, 2012) 
O enquadramento interpretativo internacional fortaleceu os processos nacionais de mobilização e delimitou o tema do aborto à área da saúde pública e dos direitos humanos. Apenas uma minoria de projetos pró -aborto avançou em relação a enquadramentos de gênero, mencionando a autonomia ("aborto como um direito da mulher de decidir sobre seu próprio corpo”) e tecendo críticas à cultura patriarcal. Após o ano 2000, nenhum projeto de lei pró-aborto era fundamentado no empoderamento das mulheres; as propostas desse período eram inteiramente justificadas pelo enquadramento da saúde pública. Esse enquadramento assinala as consequências do aborto ilegal - altas taxas de mortalidade e de lesões entre as mulheres - e enfatiza sua distribuição desigual, segundo raça e classe. Um dos projetos de lei relacionava o aborto inseguro a práticas de violência, construindo mulheres como vítimas da proibição. O enquadramento da saúde pública permitiu, portanto, a elaboração de uma posição pró-aborto a partir do discurso de proteção, em oposição àquele que enfatizava a autonomia.

Apesar de o Legislativo ter sido um espaço fundamental para a disputa entre integrantes de movimentos e de contramovimentos, mudanças na regulação do aborto não foram alcançadas por meio desse caminho, com projetos de lei pró-aborto frequentemente suscitando projetos antiaborto, e assim por diante - todavia, o Legislativo foi progressivamente ocupado pelo contramovimento.

A demanda por uma lei sobre violência doméstica também era fortemente justificada tanto pelo PNPM quanto pela esfera internacional, diante da necessidade de alinhar o sistema jurídico brasileiro às convenções internacionais e acordos ratificados pelo Estado. A mobilização se intensificou e teve seu auge com a provocação do Sistema Interamericano de Direitos Humanos, que considerou, no caso Maria da Penha, o Estado brasileiro responsável por omissão e negligência no combate à violência doméstica. Em 2002, a campanha pela Lei Maria da Penha foi lançada, com a formação de um consórcio de ONGs atuantes na área de violência contra as mulheres e direitos humanos. (ALVAREZ, 1998; MACIEL, 2011) Esforços conjuntos entre esse grupo e a Secretaria Especial de Políticas para Mulheres resultaram em projeto de lei submetido ao Congresso. 
Após negociações difíceis e advocacy, o projeto foi aprovado em 2006, ensejando a criação da lei n. 11.340/2006, conhecida como Lei Maria da Penha em referência às origens da campanha que resultou em sua aprovação. A lei foi considerada uma importante vitória pelos movimentos feministas e, nos anos seguintes, enfrentou desafios relativos à sua aplicação. Apesar de apenas algumas poucas varas e tribunais terem questionado sua constitucionalidade, a oposição à lei alcançou o debate público. A SPM e o Executivo recorreram ao STF como uma estratégia para fortalecer a implementação da lei. ${ }^{18}$ No dia 9 de fevereiro de 2012, o STF confirmou a constitucionalidade da Lei Maria da Penha.

Uma tentativa similar de ligar os movimentos e o Executivo à meta de mudar a lei foi feita no que diz respeito ao aborto. Com base no PNPM, o governo federal procurou avançar na questão do aborto, envolvendo tanto o Legislativo quanto uma comissão tripartite composta por representantes do Executivo, da sociedade civil e do próprio Legislativo. Um projeto de lei foi enviado ao Congresso para propor a descriminalização do aborto até a décima segunda semana de gestação. (ROCHA, 2006)

Após uma ofensiva dos grupos religiosos, o projeto perdeu o apoio do Executivo e seu trâmite foi interrompido no Legislativo. O contramovimento se mobilizou, nas esferas institucionais e informais, com o intuito específico de impedir quaisquer avanços no tema do aborto. Em 2006, a Frente Parlamentar pela Defesa da Vida e o movimento Brasil sem Aborto se formaram e teve início o lobby pela revisão da norma técnica de 1998 e pela aprovação de um conjunto de projetos de lei conservadores. Além de intervirem em instituições governamentais, grupos pró-vida lançaram a Campanha Nacional pela Vida e promoveram manifestações em todo o país. Esses grupos também exerceram considerável influência

18 Em 2007, a Casa Civil propôs a Ação Direta de Constitucionalidade (ADC) 19 para requerer a confirmação da constitucionalidade dos artigos mais controversos da lei, a saber: artigo ${ }_{10}$ (aplicação da lei restrita a mulheres não fere o princípio da isonomia), artigo 33 (criação dos Juizados de Violência Doméstica e Familiar contra a Mulher não fere a competência dos estados de disporem sobre a organização judiciária local) e artigo 41 (exclusão da aplicação da lei n. 9.099/1995 para crimes relativos a violência doméstica e familiar contra a mulher). Em 2010, o STF recebeu também a Ação Direta de Inconstitucionalidade (ADI) 4.424, proposta pela Procuradoria Geral da República, que questionava a necessidade de autorização das muIheres para dar seguimento à ação penal relativa à lesão corporal. 
sobre as eleições à Presidência da República e aos cargos do Congresso Nacional. Lula, então candidato à Presidência, enfrentou forte resistência por ter adotado medidas pró-aborto em seu primeiro mandato. O patrulhamento ideológico de aspirantes ao Legislativo foi conduzido por meio da campanha "Por um Parlamento em Defesa da Vida", com o lema "Vote pela Vida: Vote em Candidatos contra o Aborto".

Encurralado pelas suspeitas de envolvimento em escândalos de corrupção, o segundo governo Lula (2006-2010) retrocedeu em relação ao direito ao aborto. ${ }^{19} \mathrm{O}$ governo se encontrava enfraquecido e com menos popularidade, o que levou o Executivo a se esquivar de discussões a respeito de causas impopulares como o aborto, para conseguir o apoio dos setores conservadores para manter a governabilidade. Na campanha eleitoral de 2010, que contou pela primeira vez com uma candidata na disputa, o aborto se tornou um tema central. Dilma Rousseff foi duramente censurada ao apoiar a primeira versão do terceiro Plano Nacional de Direitos Humanos (PNDH-3). A cobertura da imprensa relativa à questão do aborto foi intensa e todos os candidatos presidenciais na eleição de 2010 foram questionados quanto a suas posições diante do tema. (MACHADO, 2012) Perante forte pressão, a então candidata Dilma Rousseff foi forçada a se retratar e assinar a Carta Aberta ao Povo de Deus, jurando que, se eleita, não tomaria providências a favor da legalização do aborto, promessa que manteve durante os dois mandatos.

Entre 2000 e 2010, o movimento conservador ganhou aliados no Parlamento. O número de projetos de lei antiaborto superou o número daqueles que visavam à expansão do direito ao aborto. Também houve uma mudança significativa no enquadramento e nos tipos de projetos propostos pelos conservadores. Além de insistirem na criminalização das mulheres que abortam, projetos conservadores passaram a adotar um enquadramento protetivo, garantindo direitos ao feto e solicitando o fornecimento de assistência social para mulheres que não recorrem ao aborto, especialmente aquelas que escolhem não fazer uso dos limitadíssimos serviços de aborto legal. Mais impressionante é a maneira pela qual o quadro da 
proteção às mulheres, uma importante estratégia do movimento feminista, passa a ser disputado e apropriado pelo contramovimento.

A principal vitória do movimento feminista em relação aos direitos sexuais e reprodutivos nesta década foi obtido em 2012 no STF, no âmbito da Ação de Descumprimento de Preceito Fundamental (ADPF) 54. Após mobilização sistemática da sociedade civil, que envolveu organizações pró e contra o aborto que se manifestaram em audiência pública como amici curiae, o STF reconheceu outra forma de aborto legal: na hipótese de o feto ser comprovadamente anencefálico. Foi a primeira vez em um século que uma decisão jurídica expandiu as barreiras do aborto legal. A declaração de constitucionalidade da Lei Maria da Penha pelo STF ocorreu no mesmo ano, mas o problema da violência doméstica era tido como de muito mais alta prioridade na agenda governamental. Na sequência da aprovação da lei, o governo lançou uma campanha sobre a Lei Maria da Penha sob o slogan "A Lei é Mais Forte" e promoveu sua implementação por meio da reestruturação de órgãos públicos, da instalação de novos serviços e de campanhas para disseminar a lei na esfera pública e entre profissionais atuantes na aplicação da lei. A maior presença de parlamentares religiosos e de matiz conservador não inibiu outra vitória das feministas no campo legislativo: a adoção da lei do feminicídio em 2015. Da mesma forma que a Lei Maria da Penha, a aprovação da lei do feminicídio foi produto de uma intensa discussão e negociação envolvendo ONGs e instituições, bem como fatores internacionais..$^{20} \mathrm{O}$ projeto de lei foi promovido pela bancada feminista do Congresso Nacional e contou com o apoio de vários partidos, inclusive dos setores mais conservadores. A proposta mencionava a importância de reconhecer que mulheres são mortas

20 O projeto foi resultado do trabalho da Comissão Parlamentar Mista de Inquérito (CPMI) da Violência Doméstica contra a Mulher, composta por integrantes da Câmara dos Deputados e do Senado Federal, que viajaram por 18 estados brasileiros, conduzindo reuniões e audiências públicas e colhendo documentos e depoimentos. O relatório final da CPMI diagnosticou uma "curva ascendente de feminicídios [...], a permanência de altos padrões de violência contra mulheres e a tolerância estatal" (BRASIL, 2013, p. 7) e propôs mudanças na legislação para aprimorar o enfrentamento da violência contra as mulheres. A justificativa do projeto de lei faz referência ao panorama internacional, como a atuação da ONU, a condenação do Estado mexicano pela Corte Interamericana no caso Campo Algodonero e iniciativas de inserção do feminicídio nas legislações de países da América Latina. 
porque são mulheres, "expondo a fratura da desigualdade de gênero que persiste em nossa sociedade".

Entretanto, durante a votação na Câmara dos Deputados, o projeto original passou por uma alteração de imensa importância: a expressão “contra a mulher por razões de gênero" foi substituída pela frase "contra a mulher por razões da condição do sexo feminino". A retirada da palavra gênero era uma exigência de Eduardo Cunha, então presidente da Câmara dos Deputados - o mesmo parlamentar que anunciou que uma votação para legalizar o aborto só aconteceria por cima de seu cadáver. O episódio ilustra a oposição a questões relacionadas a gênero no Congresso, mas também os meandros pelos quais a atuação na área de violência doméstica pôde contornar esse problema. Conservadores aceitam a ideia de proteger a mulher, mas querem evitar que a lei seja aplicada a grupos outros que não as mulheres, como travestis e pessoas transgênero.

A análise precedente revela a circulação e o intenso fluxo da mobilização no interior de esferas formais e institucionais na definição das políticas de gênero, em que respostas institucionais e legitimidade pública são simultaneamente construídas e se retroalimentam. Ou a mobilização pública é posta em marcha para fortalecer uma iniciativa institucional, ou fluxos institucionais dão impulso para disputas morais na sociedade. Enquadramentos legais - compreendendo tanto a linguagem do direito como concepções moralizantes - mostraram-se importantes não apenas na instrumentalização das estratégias institucionais (como a apresentação de um projeto de lei ou o ajuizamento de uma ação perante o STF), mas na ativação do debate público. A seção seguinte analisa duas importantes vitórias do movimento feminista perante o STF com o objetivo de traçar mais pormenorizadamente como negociações sobre maneiras de interpretar a realidade se relacionam com conquistas concretas do movimento social feminista.

\section{Caminhos perigosos: da proteção das mulheres à proteção da família}

Apesar de a Lei Maria da Penha admitir expressamente a existência da violência baseada no gênero, reconhecendo as hierarquias de gênero e 
os direitos humanos das mulheres, há aí dois movimentos ambivalentes. Primeiramente, a violência de gênero é restrita ao doméstico e ao ambiente familiar. Na arquitetura da Constituição Federal, essa previsão está de acordo com o disposto no artigo 226, parágrafo $8^{\circ}$, que estabelece que o Estado “assegurará a assistência à família na pessoa de cada um dos que a integram, criando mecanismos para coibir a violência no âmbito de suas relações”. Em segundo lugar, as políticas públicas previstas, que promovem a prevenção, assistência social às mulheres em situação de violência doméstica, medidas protetivas de urgência e penas mais altas, têm um caráter que é essencialmente de proteção.

A decisão de optar por esses enquadramentos - proteção e família foi bastante bem-sucedido em granjear espaço no sistema jurídico-legal e na agenda de políticas públicas. A violência exercida contra esposas e companheiras desperta indignação. Apelos pela "dignidade humana" das mulheres (reconhecida até mesmo por encíclica católica) e por uma "vida livre de violência" são capazes de penetrar até mesmo os contextos mais conservadores. A figura da mulher-vítima (esposa e mãe) gera simpatia e pode atrair aliados para a causa sem gerar oposição. Ao mesmo tempo, a ideia de proteção contra uma agressão ainda permite o enfoque dos direitos humanos e a expansão de possibilidades para o acesso ao sistema de justiça - foi essa linha de argumentação que possibilitou que o caso Maria da Penha fosse levado ao Sistema Interamericano. Essa ideia também foi decisiva na defesa da lei contra supostas inconstitucionalidades. No quadro da proteção, contudo, mulheres são construídas como sendo similares a outras figuras tidas como vulneráveis dentro da família, como as crianças e os idosos, grupos que inspiram proteção. (DEBERT; GREGORI, 2008, p. 170) No debate em torno da aplicação da lei, a proteção acaba colidindo com a autonomia. A circunscrição da violência de gênero ao espaço doméstico e à família pavimentou o caminho para que a lei viesse sob o escopo mais amplo da proteção à família.

Por razões de espaço, não procederemos aqui à análise das consequências contraprodutivas do uso desses enquadramentos, mas estudiosos têm destacado os efeitos negativos para as mulheres quando o sistema de justiça decide agir em nome da proteção à família. Esses efeitos variam: de mulheres que não conseguem registrar o boletim de ocorrência 
na delegacia àquelas que são pressionadas pelas autoridades públicas a perdoarem ou se reconciliarem com os agressores para a manutenção da família. (ALVAREZ et al., 2010; MaCAULAY, 2006) A diluição da violência de gênero dentro da política de proteção à família também leva ao risco de evitar a discussão sobre a assimetria de poder entre os gêneros dentro do ambiente familiar. (DEBERT; GREGORI, 2008) Além disso, o enquadramento no núcleo familiar acarreta a exclusão de outras formas de violência de gênero do sistema de proteção, como a violência racista e a violência contra prostitutas e travestis. A seleção de vítimas legítimas a demandarem proteção - a mulher heterossexual não autossuficiente, a esposa dependente sem agência - e a definição de formas aceitáveis de violência (pela qual a violência baseada no gênero é minimizada) cria o que Cecilia Santos (1999) chamou de "cidadania contraditória”.

Em relação ao questionamento da Lei Maria da Penha pelo Judiciário, o argumento mais frequentemente usado contra a constitucionalidade da lei basou-se no princípio da igualdade, já que a lei é aplicada apenas em casos de violência doméstica contra mulheres. Muitas decisões defendiam a lei criticando visões a respeito da igualdade formal e reafirmando o quadro da proteção. A lei também foi defendida por especialistas e juízes/ as de direito como uma lei que protege a família, em detrimento de uma postura de defesa dos direitos das mulheres tendo em conta a condição de gênero per se. Ações afirmativas em favor de minorias compuseram o debate nas decisões judiciais em diferentes tribunais de justiça, mas o enquadramento da proteção definiu as mulheres como indivíduos vulneráveis, à semelhança de idosos e crianças. ${ }^{21}$ Quando o caso chegou ao STF, esses argumentos também foram usados para sustentar decisões a favor da lei. O Ministro Marco Aurélio Mello, relator do processo, postulou que uma diferenciação baseada no gênero da vítima não seria uma medida ilegítima ou desproporcional, já que as mulheres são vulneráveis no que diz respeito à violência que ocorre na família. Ele também comparou a Lei

21 Em 2009, o Tribunal de Justiça do Rio Grande do Sul decidiu que o Estado tem o poder de "estabelecer leis para proteger grupos de indivíduos vulneráveis" (BRASIL, 2009a). No mesmo ano, em outro caso do TJ-RS decidiu-se que a proteção a idosos, crianças e adolescentes são exemplos constitucionais do "poder legislativo do Estado para criar leis que estabelecem tratamento especial para grupos minoritários de cidadãos” (BRASIL, 2009b). 
Maria da Penha a outras leis aprovadas para proteger grupos considerados carentes, como o Estatuto da Criança e do Adolescente e o Estatuto do Idoso.

O enquadramento da proteção colidiu diretamente com a autonomia quando se tratou da possibilidade de as mulheres decidirem acerca da continuidade do processo criminal de seus agressores. A maioria dos ministros do STF votou pelo oferecimento da denúncia independentemente da opinião da vítima, com fundamento na necessidade de proteger as mulheres contra as pressões exercidas pelos agressores. O Ministro Marco Aurélio observou que, na vasta maioria dos casos, as vítimas tendem a retirar a queixa, na tentativa de garantirem sua própria segurança. Ele afirmou que atribuir às vítimas a decisão quanto a se e quando devem dar início ao processo equivaleria a desprezar o medo, as ameaças, pressões psicológica e econômica e, ainda, desigualdades de poder determinadas histórica e culturalmente, além de reduzir a proteção à vítima e perpetuar a violência, a discriminação e os atentados à dignidade humana.

O Ministro Cezar Peluso foi a única opinião dissidente nesse ponto: sua posição ambivalente vacilou entre a autonomia da mulher e a proteção à família. Ele explicitamente refutou o argumento de outros ministros acerca da relutância de vítimas mulheres em darem andamento ao processo, enfatizando a importância do “exercício do núcleo substancial da dignidade da pessoa humana, que é a responsabilidade do ser humano pelo seu destino". De acordo com o Ministro Peluso, desconsiderar a relutância da mulher em prestar queixa enseja dois riscos: primeiro, a possibilidade de as mulheres se intimidarem e não procurarem ajuda, já que não seriam capazes de influenciar o curso da ação criminal ou interrompê-la; segundo, a possibilidade de o agressor ser condenado, levando a consequências imprevistas para a família nos casos em que houve o restabelecimento do relacionamento. Por um lado, o Ministro Peluso sublinhou a importância de reconhecer a autonomia das mulheres e os riscos de defini-las apenas como vítimas. Por outro lado, também afirmou a importância de proteger a família, reforçando a reconciliação do casal como um valor a ser protegido pelo Judiciário. Assim, o Ministro Peluso articulou um discurso ambivalente segundo o qual a autonomia da mulher é reconhecida como um meio para a proteção da família. Essa 
interpretação dos objetivos da lei não foi isolada nem nova. Outros ministros do STF - Luiz Fux e Ricardo Lewandowski - defenderam a constitucionalidade da Lei Maria da Penha referindo-se à proteção da família prevista na Constituição Federal. Em outras instâncias, a proteção da família provou ser um importante quadro moral usado por juízes/as para defender a constitucionalidade da legislação sobre violência doméstica. ${ }^{22}$

\title{
Aborto: o uso dos enquadramentos da proteção e da família em competição
}

\begin{abstract}
A gente tem que considerar que esse controle [das mulheres sobre seus corpos] pode criar problemas muito sérios na estrutura familiar e no casamento, se há uma gravidez é isso que o marido quer [...]. Acho que a mulher que é feliz e a mulher que tem um casamento estável, uma mulher que tem amor por seu marido e que ama seus filhos depois de crescidos [...], uma mulher nessas condições, ela nunca vai aderir a essas posições favoráveis ao aborto, posições que podem levar ao divórcio, posições que podem causar a ruína da família e do casamento. ${ }^{23}$
\end{abstract}

O comentário acima foi feito por um deputado federal durante a Assembleia Nacional Constituinte, em oposição às propostas de revisão da criminalização do aborto formuladas por feministas. Nesse discurso, o legislador argumentou que o direito ao aborto e o controle das mulheres sobre seus próprios corpos significaria a destruição da família. Os enquadramentos pró-vida e pró-família sempre foram associados a discursos do contramovimento. Para o movimento antiaborto, a pauta do aborto desafia o modelo normativo reprodutivo, a sacralidade da maternidade e

22 Várias decisões de tribunais de justiça defendem a lei como um mecanismo de proteção da família - "o valor da lei é proteger a família e cada um dos indivíduos que a compõem, uma previsão também contida na Constituição". Ao proteger as mulheres, o Estado estaria se dirigindo à sua condição de gênero e prestando assistência às famílias pela criação de mecanismos para prevenir a violência nos relacionamentos, como previsto na Constituição. A lei deve ser defendida, já que "a prática da violência doméstica acarreta, como regra, consequências danosas para toda a instituição familiar". (BRASIL, 2009C)

23 Discurso do Deputado federal João de Deus (PT), em 1988, na Comissão da família, educação, cultura e esporte, ciência, tecnologia e comunicação - Subcomissão da Família, do Menor e do Idoso. (BRASIL, 1988, p. 94) 
o sistema da família tradicional, em qu as mulheres não têm autonomia para tomada de decisões sobre seus próprios destinos. Os primeiros documentos antiaborto divulgados pela Conferência Nacional dos Bispos do Brasil (CNBB) - a Exortação Apostólica Familiares Consortio (1981) e a Carta dos Direitos da Família (1983) - enfatizavam os perigos das relações homossexuais e do aborto aos valores cristãos de moral e família. Um dos objetivos propostos no primeiro encontro nacional do movimento antiaborto em 1994 era alinhar as ações antiaborto e monitorar a mobilização feminista no Congresso e projetos de leis em andamento "que desafiassem valores familiares e a vida conforme os mandamentos católicos".

Nas eleições de 2006, o tema da defesa da vida e da família foi intensivamente explorado na esfera pública. A Igreja Católica lançou o documento Declaração sobre Exigências Éticas em Defesa da Vida, que pretendeu "mobilizar famílias e comunidades a encorajarem vereadores, deputados e senadores de sua base eleitoral para defender e promover a vida e a família”. (CONFERÊNCIA NACIONAL DOS BISPOS DO BRASIL, 2008) No mesmo ano, a Associação Nacional de Mulheres pela Vida (2005), do Rio de Janeiro, lançou o Manifesto em Defesa da Vida que trata da "vocação [das mulheres] para a maternidade" e sua "sublime missão de transmitir e preservar a vida”. Apesar de os argumentos mais radicais e contraculturais de liberação sexual e liberdade de escolha e sobre o corpo terem sido residuais no movimento feminista brasileiro, que optou pelo quadro da saúde pública, o discurso antiaborto enfatizou o aborto como algo inerentemente prejudicial à família. (REZENDE, 2016)

É difícil medir a importância e o impacto da oposição ao aborto com base no quadro da família. Mas é notável que uma das únicas e mais importantes vitórias pró-aborto - o caso do feto anencéfalo no STF - tenha emergido desse quadro e tenha conseguido assumir a discussão nesse ponto. A estratégia legal perseguida pelas feministas consistia em diferenciar o caso do feto anencéfalo do aborto em geral, contornando, por conseguinte, as dificuldades legais e morais e os obstáculos colocados pelo debate sobre aborto. ${ }^{24} \mathrm{~A}$ interrupção da gravidez envolvendo um feto

24 De acordo com Débora Diniz, pesquisadora do ANIS Instituto de Bioética, Direitos Humanos e Gênero, entidade signatária da ação perante o STF, o conceito de antecipação terapêutica 
viável envolveria colocar na balança os prós e os contras supostamente em jogo: de um lado, a vida potencial do nascituro e, de outro, a liberdade e a autonomia individual da mulher grávida. Ainda no caso do feto anencéfalo, conforme se argumentou, esse conflito não estava presente, já que não havia vida fetal a ser protegida. Tampouco era o caso de mulheres que não haviam escolhido a maternidade e, sim, mulheres que queriam ser mães, mas não podiam, diante da inviabilidade do feto. Ao longo da audiência pública, organizações feministas tentaram levar histórias à Corte (apresentadas pessoalmente ou por meio de relatórios e filmes) de mulheres que haviam requerido a interrupção dessa gravidez.

Os relatos sempre envolviam mulheres que desejavam ser mães, em sua maioria casadas. No caso da anencefalia, uma criança desejada e "amada antes mesmo da concepção" foi retratada como fatalmente afetada por um diagnóstico irreversível. Um casal (e não a mulher, apenas) que havia vivenciado a gravidez de um feto anencéfalo e conseguido interrompê-la compareceu à audiência pública com duas filhas - sinalizando que a interrupção da gravidez no passado não havia contrariado o projeto familiar. Uma ativista feminista de grande expressão, em audiência pública realizada em 28 de agosto de 2008 , manifestou que mulheres que recorrem ao aborto não são "futuras mães, mas mulheres que não desejam uma gravidez em um momento determinado de suas vidas", ${ }^{25}$ sustentando que, de outro modo, uma mulher que interrompe uma gestação de feto anencéfalo tinha uma identidade como mãe e um desejo pela maternidade. Afastar-se do aborto em geral foi uma estratégia-chave para assegurar o sucesso da ação. Em suas decisões, ministros que votaram pela concessão do pedido deixaram claro que não estavam decidindo sobre o aborto em geral e que seus votos não podiam, por conseguinte, ser usados como precedente nessa questão.

De fato, a santidade da maternidade foi resgatada e defendida por ministros que votaram a favor do procedimento: por exemplo, o Ministro Ayres Britto afirmou que "a gravidez é um processo voltado para o

do parto daria uma guinada legal, ética, médica e moral para os termos do debate sobre o aborto.

Intervenção feita por Débora Diniz em audiência pública no STF. (BRASIL, 2008, p. 103) 
espetáculo do mundo, para o espetáculo da vida” o que “o conteúdo mais sublime e mais forte de todos os amores [é] o amor materno", ${ }^{26}$ enquanto a Ministra Carmen Lúcia argumentou que "a dignidade da mãe vai além dela mesma, além de seu corpo”. (BRASIL, 2012, p. 174) Não analisamos todas as razões para as decisões aqui, mas ressaltamos que entre os ministros que decidiram a favor da antecipação terapêutica do parto no caso de feto anencéfalo, não havia incompatibilidade entre essa posição e a defesa da família, da repronormatividade e da sacralidade da maternidade. O enquadramento da autonomia, pouco explorado por ativistas pró-escolha durante a audiência pública, só foi mencionado por alguns ministros, que apesar disso não reconheceram a escolha em todas as circunstâncias, mas somente quando a autonomia era contraposta à vida não viável, como de depreende do voto do Ministro Marco Aurélio: “está em jogo o direito da mulher de autodeterminar-se, de escolher, de agir de acordo com a própria vontade num caso de absoluta inviabilidade de vida extrauterina". (BRASIL, 2012, p. 67).

Organizações defendendo a medida enfatizaram o sofrimento de mulheres e empregaram um paralelo com a tortura, sustentando que ser obrigada a prosseguir com a gestação de feto anencéfalo até o fim para, depois do parto, enterrar a criança, constituía uma forma de tortura. O sofrimento das mulheres foi reconhecido em vários votos a favor da aprovação e foi tratado na maioria dos casos sob o quadro da dignidade. Entretanto, alguns ministros que reconheceram o sofrimento como uma razão para autorizar o procedimento destacaram que a dor não era apenas das mulheres, mas também do pai e da família. A manutenção compulsória da gravidez, de acordo com o Ministro Marco Aurélio, "resulta na imposição sobre a mulher, ou sua respectiva família, de dano à sua integridade moral e psicológica”. (BRASIL, 2012, p. 14)

A Ministra Cármen Lúcia atestou que é preciso lembrar que "o pai também sofre barbaramente; que a família pode sofrer e se desfacelar e isso não é incomum; que o direito do pai também precisa ser contado nessa discussão [...]. Quando falamos em dignidade, estamos falando de

26 As manifestações do então Ministro Carlos Ayres Britto constam da decisão sobre medida cautelar na ADPF 54. (BRASIL, 2004) 
todos: do feto, da mulher, do pai, do que seria o irmãozinho mais velho [...]”. (BRASIL, 2012, p. 175) A imagem da mulher vítima de sofrimento e de tortura não apenas teve apelo maior que a da mulher que exerce suas vontades em relação a seu corpo, mas também se beneficiou de avanços obtidos nos últimos anos no quadro mais amplo da violência, particularmente quando se têm em conta campanhas focadas na violência doméstica e a aprovação e a implementação da Lei Maria da Penha. Os ganhos, bem como os perigos dessa abordagem, são evidentes.

O caso da gravidez de feto anencéfalo demonstra como o movimento e o contramovimento podem competir pelo mesmo enquadramento. $\mathrm{O}$ da família, que sempre foi o pilar da posição do movimento antiaborto, foi usado pelo movimento pró-escolha para neutralizar a oposição ao aborto. Já o da proteção também foi empregado para se referir à proteção das mulheres, entretanto, como demonstramos, isso pode ser rapidamente apropriado como uma maneira de justificar a proteção da família.

\section{Conclusão: enquadramentos, negociações estratégicas e ambivalências}

A constituição dual do movimento feminista brasileiro (e latino-americano), contendo demandas e ativistas femininas e feministas, revela dinâmicas diferentes entre demandas do movimento social e arenas institucionais. Apesar de tanto violência quanto aborto serem temas importantes para o movimento, um e outro mostram desdobramentos marcadamente diferentes em termos de vitórias institucionais. No que diz respeito a conseguir aliados, e não opositores, e a assegurar maior aceitação na esfera pública e nas instituições formais, os temas menos controversos em relação aos arranjos tradicionais de gênero tendem a ser mais bem-sucedidos.

Este artigo ofereceu uma breve comparação entre os campos da violência e do aborto no Brasil, com base numa análise dos eventos e na observação do ambiente politico, moral e cultural, o que ora facilitou, ora dificultou a ocorrência de mudanças. O movimento para assegurar a legislação sobre violência doméstica foi favorecido por um conjunto de 
elementos, incluindo o papel do Executivo na formação da política pública, sua abertura para atores e discursos do movimento social, a ausência de forças de oposição, e maior receptividade para a questão da esfera pública. Em contraste, a estagnação do movimento pelo aborto e os riscos de retrocessos para as mulheres ocorreram dentro de um contexto que incluiu a perda de aliados institucionais, colonização do parlamento por grupos de oposição e a organização de um forte contramovimento que mobilizou a sociedade em bases morais. Argumentamos aqui que a habilidade de ambos os temas para permearem contextos institucionais é afetada por seus quadros discursivos e contextos sociomorais dentro dos quais são mobilizados. Oportunidades escasseiam ou aumentam de acordo com os processos de negociação com valores tradicionais e conceitos de gênero e de família. Nos dois casos analisados, o conflito político envolveu um jogo estratégico na utilização de enquadramentos por atores institucionais, movimentos e contramovimentos.

Enquanto a defesa de concepções tradicionais da família e papeis a serem desempenhados pelas mulheres foi central para o movimento antiaborto, o movimento feminista se voltou para quadros mais negociados, evitando, assim, conflitos diretos. A violência de gênero adquiriu um enquadramento mais palatável, como violência doméstica, marital ou familiar, reforçando o quadro da proteção em oposição ao da autonomia. Em todos os casos a proteção das mulheres foi muito importante para justificar a política pública, inclusive na esfera legal. A aprovação da lei do feminicídio - que excluiu "gênero" de sua redação - revela um aspecto impressionante da contenção de pautas feministas no Brasil: que o enquadramento de gênero por si mesmo pode representar um obstáculo para a institucionalização de certas demandas feministas.

No que diz respeito ao aborto, o discurso inicial da autonomia da mulher entre as feministas dos anos 1970 moveu-se para uma linguagem de direitos reprodutivos e saúde pública nos anos 1990, sob influência das conferências internacionais de Cairo e Pequim. As altas taxas de mortalidade feminina em decorrência de abortos inseguros fortaleceram o argumento da saúde pública. Enquadramentos de proteção que enfatizam a vitimização de mulheres também foram considerados: mulheres como 
vítimas de violência sexual, mulheres sofrendo por causa da gestação de um feto anencéfalo, ou mulheres vítimas da prática de aborto inseguro. A pauta do aborto só avançou por meio da ocupação furtiva de espaços institucionais, bem distantes da visibilidade pública. A norma técnica que regulamenta o aborto legal emergiu no guarda-chuva de procedimentos a serem adotados em caso de violência sexual. Camuflar o aborto como "profilaxia à gravidez" ou "antecipação terapêutica do parto" foi um recurso para obter progressos em esferas institucionais. Mesmo assim, foi difícil superar o conflito colocado pela ênfase do contramovimento no papel da mulher como mãe e na proteção da família. A mais significativa vitória do movimento feminista no STF só foi alcançada por meio de um processo de negociação argumentativa. Nos dois casos expostos, as decisões do STF favoráveis às mulheres afirmaram os quadros da proteção e da família.

Enquadramentos legais não são usados apenas para instrumentalizar ações institucionais, eles também se movem entre as esferas pública e privada. Em se tratando da mobilização legal, é importante observar não apenas as instituições, mas também o fluxo e os deslocamentos que ocorrem, seja em disputas por estratégias institucionais, seja dentro da esfera pública. A linguagem do direito é usada em campanhas e discursos dentro da esfera pública e discursos morais são articulados dentro das esferas institucionais formais. Ao permitir a observação da conexão entre aspectos sistêmicos do direito e de argumentos morais, religiosos, culturais e científicos, a categoria do framing fornece uma perspectiva privilegiada para observar essas dinâmicas. Dentro desse fluxo de quadros móveis, disputas simbólicas e institucionais são mutuamente reforçadas. Por exemplo, no caso da violência doméstica, a vitória na Comissão Interamericana que catalisou a mobilização de ONGs no nível nacional foi usada para fortalecer a campanha pela lei, uma demanda que existia já há algum tempo. A vitória consubstanciada na adoção da lei, por seu turno, serviu como capital simbólico para a disseminação - como mencionado anteriormente, “a lei é mais forte" era o lema de uma das principais campanhas que visavam ao aumento da conscientização pública e o fortalecimento dos processos 
criminais de violência doméstica. Além disso, o STF foi usado para fins de consolidação, simbólica e material, da lei.

Por outro lado, enquadramentos também corporificam o relacionamento entre as respostas institucionais, movimentos e contramovimentos. A presença do oponente no campo de batalha desencadeia um processo proativo de argumentos contrários e de modulação dos enquadramentos com o objetivo de evitar ou reduzir o conflito. No caso do aborto, o conflito moral acionado por conservadores na esfera pública pode explicar os revezes que o direito ao aborto sofreu institucionalmente, bem como a estratégia usada por feministas de apelar para enquadramentos menos radicais e investir na ocupação de espaços menos visíveis. Há uma dimensão adicional do uso dos enquadramentos interpretativos nas disputas dentro de instituições formais - particularmente tribunais como um palco para a projeção do confronto em outras esferas. (BARKAN, 2007; KIRCHHEIMER, 1961) Nesse sentido, para além do próprio resultado do caso no tribunal, a função de qualquer controvérsia é expandir o escopo do confronto e das estruturas ali mobilizadas. Enquadramentos que são mais vantajosos para ganhar o caso podem não ser, de fato, aqueles que têm maior impacto sobre o discurso moral dominante. As estratégias discursivas dos movimentos dentro das instituições estatais são resultado de uma tensão permanente entre duas dimensões em qualquer disputa: enquadramentos negociais para avançar na garantia de direitos e aqueles implantados para amplificar enquadramentos em confronto.

Em resposta à forte presença do contramovimento no caso do aborto, a estratégia do movimento feminista brasileiro, de focar na mobilização institucional, significou o uso de quadros mais negociados. Foi apenas quando o movimento deixou as instituições e foi às ruas e à Internet que a agenda se tornou mais radical. Tendências recentes sinalizam a radicalização da política nos campos da violência e do aborto. No que diz respeito à violência, a acomodação semântica por meio dos termos família e domesticidade está sendo questionada e o enquadramento interpretativo regulatório está crescentemente sendo usado para assumir outras formas de violência de gênero. 
A maior atenção para a violência sexual e a violência contra a população LGBTI ampliou o escopo do debate e destacou conflitos que extrapolam o ambiente da família. Em relação ao aborto, na proporção em que formas institucionalizadas de ativismo foram sendo percebidas como menos promissoras, o movimento se tornou mais radical, tanto no concernente a seu repertório quanto a seu enquadramento interpretativo. O feminismo jovem, menos institucionalizado e mais disposto a explorar os temas da sexualidade e do corpo, avançou e retornou para as ruas em 2015, no que se convencionou chamar "primavera feminista". ${ }^{27} \mathrm{Sob}$ as bandeiras "fora Cunha" (contra o deputado federal da bancada evangélica Eduardo Cunha) e "meu corpo, minhas regras", a luta pelo direito ao aborto e contra os revezes conservadores tomou um formato mais disruptivo. A politização do gênero no futuro do movimento de mulheres brasileiro parece inevitável.

\section{Referências}

ALEXY, R. A Theory of Legal Argumentation. Oxford: Clarendon Press, 1989.

ALVAREZ, M. C. et al. O papel da vítima no processo penal. Brasília: Ministério da Justiça, 2010. (Série Pensando o Direito, n. 24)

ALVAREZ, S. E. Engendering Democracy in Brazil: Women's Movements in Transition Politics. Princeton: Princeton University Press, 1990.

ALVAREZ, S. E. Latin American feminisms 'Go Global': trends of the 1990 and challenges for the new millennium. In: ALVAREZ, S. E.; DAGNINO, E.; ESCOBAR, A. (Ed.). Cultures of Politics, Politics of Cultures: Re-visioning Latin American Social Movements. Boulder: Westview Press, 1998. p. 293-324.

27 A "primavera feminista" foi o pico da mobilização feminista em 2015, que começou com campanhas nas redes sociais e que depois tomou as ruas. A campanha \#primeiroassedio, que estimulava mulheres a relatarem a primeira vez em que foram assediadas, foi reproduzida mais de cem mil vezes no Twitter. Na campanha \#meuamigosecreto, mulheres denunciaram situações cotidianas de machismo nas redes sociais. A hashtag foi mencionada 170 mil vezes no Twitter. Em novembro de 2015, durante a Marcha de Mulheres Negras, protestos contra o Estatuto do Nascituro e contra Eduardo Cunha também foram recorrentes. 
ALVAREZ, S. E.; DAGNINO, E.; ESCOBAR, A. Introduction: The Cultural and the Political in Latin American Social Movements. In: ALVAREZ, S. E.; DAGNINO, E.; ESCOBAR, A. (Ed.). Cultures of Politics, Politics of Cultures: Re-visioning Latin American Social Movements. Boulder: Westview Press, 1998. p. 1-29.

ASSOCIAÇÃO NACIONAL MULHERES PELA VIDA. Manifesto em Defesa da Vida. Rio de Janeiro, 2005. Disponível em: <http://www. defesadavida.com/index.php?pg=noticias/n_25092005>. Acesso em: 13 nov. 2018.

BRASIL. Assembleia Nacional Constituinte (1987-1988). Atas de

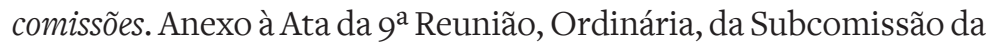
Família, do Menor e do Idoso, realizada em 29 de abril de 1987. Disponível em: < http://www.senado.leg.br/publicacoes/anais/constituinte/8c_Sub._ Familia,_Do_Menor_E_Do.pdf>.Acesso em: 13 nov. 2018.

BRASIL. Congresso Nacional. Comissão Parlamentar Mista de Inquérito sobre a Violência contra a Mulher no Brasil. Relatório Final. Brasília, 2013. Disponível em: <https://www12.senado.leg.br/institucional/omv/ entenda-a-violencia/pdfs/relatorio-final-da-comissao-parlamentarmista-de-inquerito-sobre-a-violencia-contra-as-mulheres $>$. Acesso em: 12 nov. 2018.

BRASIL. Supremo Tribunal Federal. Arguição de Descumprimento de Preceito Fundamental $n^{\circ}$ 54, Distrito Federal. Arguentes: Confederação Nacional dos Trabalhadores na Saúde - CNTS. Relator: Min. Marco Aurélio. Brasília, 12 abr. 2012. Disponível em: <http://redir.stf.jus.br/ paginadorpub/paginador.jsp?docTP=TP\&docID=3707334>. Acesso em: 12 nov. 2018.

BRASIL. Supremo Tribunal Federal. Arguição de Descumprimento de Preceito Fundamental n ${ }^{0}$ 54-8, Distrito Federal. Relator: Min. Carlos Ayres Britto. Brasília, 20 out. 2004. Disponível em: <http://redir.stf.jus.br/ paginadorpub/paginador.jsp?docTP=TP\&docID=3707334>. Acesso em: 12 nov. 2018.

BRASIL. Supremo Tribunal Federal. Notas taquigráficas da Audiência Pública para a Arguição de Descumprimento de Preceito Fundamental $n^{0} 54$ de 28 de agosto de 2008. Arguentes: Confederação Nacional dos Trabalhadores na Saúde - CNTS. Relator: Min. Marco Aurélio. Brasília, 
28. ago. 2008. Disponível em: <http://www.stf.jus.br/arquivo/cms/ processoAudienciaPublicaAdpf54/anexo/ADPF54_notas_dia_28808. pdf $>$. Acesso em: 12 nov. 2018.

BRASIL. Tribunal de Justiça do Rio Grande do Sul. Crime. Lei Maria da Penha. LF-11340 DE 2006. Violência doméstica contra a mulher. Descabimento. Ameaça. Desobediência. Provas. Inocorrência. Confissão. Reincidência. Reparação de danos. Apelação Criminal n ${ }^{0}$ 70030827380. Apelante: Jacinto Pedro Konig. Apelado: Ministério Público. Relatora: Des. Elba Aparecida Nicolli Bastos. Porto Alegre, 22 de outubro de 2009. DJe 27/10/2009a.

BRASIL. Tribunal de Justiça do Rio Grande do Sul. Crime. Habeas Corpus. Inconstitucionalidade. Artigos 17.41 e 43. Lei 11.340/06. Suspensão condicional do processo. Condições. Habeas Corpus n ${ }^{\circ} 70031748676$. Paciente: Jerri Espindola Soares. Coator: Juiz Dir. $2^{\mathrm{a}}$ Vara Criminal da Comarca de Lajeado. Relatora: Des. Elba Aparecida Nicolli Bastos. Porto Alegre, 24 de setembro de 2009. DJe 30/09/2009b.

BRASIL. Tribunal de Justiça do Mato Grosso do Sul. Crime. Desconstituição da substituição da pena privativa de liberdade pela restritiva de direitos concedida ao réu na sentença, por expressa vedação do artigo 44 da Lei Maria da Penha. Concedida a suspensão condicional da pena. Apelação Criminal no 2009.025378-7. Apelante/Apelado: Itamar Antunes dos Santos. Apelante/Apelado: Ministério Público Estadual. Relatora: Des. Dorival Moreira dos Santos. Campo Grande, 26 de novembro de 2009. DJe 02/12/2009c.

BARKAN, S. E. Criminal Persecution and the Legal Control of Protest. Mobilization International Journal, v. 11, n. 1, p. 181-195, 2007.

BARSTED, L. Legalização e descriminalização do aborto no Brasil: 10 anos de luta feminista. Revista Estudos Feministas, Florianópolis, n. ০, p. 104-130, 1992.

COMISSÃO PARLAMENTAR MISTA DE INQUÉRITO (CPMI). Senado Federal. Relatório final: Violência Doméstica Contra a Mulher. Brasília, 2013. Disponível em: <https://www12.senado.leg.br/institucional/omv/ entenda-a-violencia/pdfs/relatorio-final-da-comissao-parlamentarmista-de-inquerito-sobre-a-violencia-contra-as-mulheres $>$. Acesso em: 12 nov. 2018. 
CATÓLICAS PELO DIREITO DE DECIDIR. Pesquisa de opinião pública sobre o aborto. São Paulo, 2011. Disponível em: <http://catolicas.org.br/ wp-content/uploads/2011/o1/publicacao-Ibope-Catolicas-Aborto-2011. compressed.pdf>

CESARINO, L. M. C. N. Acendendo as luzes da ciência para iluminar o caminho do progresso: ensaio de antropologia simétrica da lei de biossegurança brasileira. 2006.244 f. Dissertação (Mestrado em Antropologia) - Universidade de Brasília, Brasília, 2006.

CONFERÊNCIA NACIONAL DOS BISPOS DO BRASIL. Declaração Sobre Exigências Éticas em Defesa da Vida. Brasília, 2008. Disponível em: <http://www.cnbb.org.br/declaracao-sobre-exigencias-eticas-emdefesa-da-vida/>. Acesso em: 12 nov. 2018.

DEBERT, G.; GREGORI, M. F. Violência e gênero: novas propostas, velhos dilemas. Revista Brasileira de Ciências Sociais, v. 23, n. 66, p. 165-85, 2008.

DEBERT, G.; GREGORI, M. F. As delegacias especiais de polícia e o projeto Gênero e Cidadania. In: CORRÊA, M. (Org.). Gênero \& cidadania. Campinas, SP: Pagu/Núcleo de Estudos de Gênero, 2002. p. 9-19.

DIDES, C. C. et al. Estudio de opinión pública sobre aborto y derechos sexuales y reproductivos en Brasil, Chile, México y Nicaragua. Santiago: FLACSO, 2011.

DWORKIN, R. Law's Empire. Cambridge, MA: Harvard University Press, 1988.

GÜNTHER, K. The sense of appropriateness: application discourse in morality and law. New York: State University of New York, 1993.

FARIA, C. F.; SILVA, V. P.; LINS, I. L. Conferências de políticas públicas: um sistema integrado de participação e deliberação?. Revista Brasileira de Ciência Política, n. 7, p. 249-284, 2012. Disponível em: <https://dx.doi. org/10.1590/So103-33522012000100011>.

FAÚNDES, A. et al. Brazilians have different views on when abortion should be legal, but most do not agree with imprisoning women for abortion. Reproductive Health Matters, v. 21, n. 42, p. 165-173, 2013.

FLINGSTEIN, N.; McADAM, D. Toward a General Theory of Strategic Action Fields, Sociological Theory, v. 29, n. 1, Mar. p. 1-26, 2011. 
GARCÍA PEREANEZ, J. A. Consideraciones sobre la despenalización del aborto en Colombia. Iatreia, v. 23, n. 3, p. 294-301, 2010. Disponibile en: <http://www.scielo.org.co/scielo.php?script=sci_arttext\&pid=So12107932010000300012\&lng=en\&tlng=>. Acceso en: 04jul. 2016.

JELIN, E. Introduction. In: JELIN, E. Ciudadania e Identidad: Las Mujeres en los Movimientos Sociales Latino-Americanos. Geneva: United Nations Research Institute for Social Development, 1987.

JOÃO PAULO II, Papa, 1920-2005. Exortação apostólica Familiaris Consortio. 22 nov. 1981. Disponível em: <http://w2.vatican.va/content/ john-paul-ii/pt/apost_exhortations/documents/hf_jp-ii_exh_19811122_ familiaris-consortio.html>. Acesso em: 12 nov. 2018.

JURKEWICZ, R. S. Quem controla as mulheres?: direitos reprodutivos e fundamentalismos religiosos na América Latina. São Paulo: Católicas pelo Direito de Decidir, 2011.

KIRCHHEIMER, O. Political Justice. The use of legal procedure for political ends. Princeton: Princeton University Press, 1961.

MACAULAY, F. Judicialising and (de)Criminalising Domestic Violence in Latin America. Social Policy and Society, v. 5, n. 1, p. 103-114, 2006.

MACHADO, M. D. C. Aborto e ativismo religioso nas eleições de 2010. Revista Brasileira de Ciência Política, n. 7, p. 25-54, 2012.

MACIEL, D. A. Ação coletiva, mobilização do direito e instituições políticas: o caso da campanha da lei Maria da Penha. Revista Brasileira de Ciências Sociais, v. 26, n. 77, p. 97-111, 2011.

McADAM, D.; TARROW, S.; TILLY, C. Dynamics of Contention. Cambridge: Cambridge University Press, 2001.

McCARTHY, J.; Zald, M. Resource Mobiliation and Social Movements: a partial theory. American Journal of Sociology, v. 82, n. 6, p. 1212-1241, 1977. MEYER, D. S.; STAGGENBORG, S. Movements, countermovements, and the structure of political opportunity. American Journal of Sociology, v. 101, n. 6, p. 1628-60, 1996.

MENDES, C. H. Neither dialogue nor last word. Legisprudence, Oxford, v. 5, n. 1, p. 1-40, 2011. 
MORAES, A. F.; SORJ, B. (Org.). Gênero, violência e direitos na sociedade brasileira. Rio de Janeiro: 7Letras, 2009.

MOLYNEUX, M. Mobilization Without Emancipation? Women's Interests, State, and Revolution. In: FAGEN, R. R.; DEERE, C. D.; CORAGGIO, J. L. Transition and Development: Problems of Third World Socialism. Berkeley: Center for the Study of the Americas, 1986.

PEDRIANA, N. From Protective to equal Treatment: Legal Framing Processes and Transformation of the Women's Movement in the 1960 . American Journal of Sociology, v. 111, n. 6, p. 1718-1761, 2006.

PONTIFICIO CONSEJO PARA LA FAMILIA. Carta de los derechos de la familia presentada por la Santa Sede a todas las personas, instituciones y autoridades interesadas en la misión de la familia en el mundo contemporáneo. 1983. Disponible en: <http://www.vatican.va/roman_curia/pontifical_ councils/family/documents/rc_pc_family_doc_19831022_family-rights_ sp.html>. Acceso en: 12 nov. 2018.

PÜSCHEL, F. Vida e morte no direito brasileiro: uma reflexão sobre a relação entre dogmática jurídica e estrutura dos tribunais a partir da decisão da ADPF n. 54. São Paulo, 2014. (Research Paper Series - Legal Studies, Paper n. 99).

REZENDE, P. J. Movimentos sociais e contramovimentos: mobilizações antiaborto no Brasil contemporâneo. Guarulhos: Universidade Federal de São Paulo, Escola de Filosofia, Letras e Ciências Humanas, 2016. RUIBAL, A. Movilización y contra-movilización legal: propuesta para su análisis en América Latina. Política y gobierno, v. XXII, n. 1, p. 175-198, 2015 .

RUIBAL, A. Reform and backlash in México abortion's Law: political and legal opportunities for mobilization and counter-mobilization. In: ANNUAL MEETING OF THE AMERICAN POLITICAL SCIENCE ASSOCIATION, Washington, DC, 2014. Paper... Washington, DC, 2014. ROCHA, M. I. B. A discussão política sobre aborto no Brasil: uma síntese. Revista Brasileira de Estudos de População, v. 23, n. 2, p. 369-374, 2006.

SADER, E. Quando novos personagens entraram em cena: experiências, falas e lutas de trabalhadores da Grande São Paulo (1970-1980). Rio de Janeiro: Paz e Terra, 1988. 
SAFA, H. I. Women's Social Movements in Latin America. Gender and Society, v. 4, n. 3, p. 354-369, 1990. Special Issue Women and Development in the Third World.

SANTOS, C. M. Ativismo jurídico transnacional e o Estado: reflexões sobre casos apresentados contra o Brasil na Comissão Interamericana de Direitos Humanos. SUR Revista Internacional de Direitos Humanos, n. 7, p. 27-57, 2007 .

SANTOS, C. M. Women's Police Stations: gender, violence and justice in São Paulo, Brazil. New York: Palgrave Mac Macmillan, 2005.

SANTOS, C. M. Cidadania de gênero contraditória: queixas, crimes e direitos na delegacia da mulher em São Paulo. In: AMARAL JUNIOR, A.; PERRONE-MOISES, C. (Org.). O cinquentenário da Declaração Universal dos Direitos do Homem. São Paulo: Edusp, 1999. p. 315-52.

SNOW, D. et al. Frame Alignment Processes, Micromobilization, and Movement Participation, American Sociological Review, v. 51, n. 4, p. 464481, 1986.

SNOW, D. et al. The Emergence, Development, and Future of the Framing Perspective: 25+ Years Since "Frame Alignment". Mobilization: An International Quarterly, v. 19, n. 1, p. 23-46, Feb. 2014.

SNOW, D. et al. The emergence, development, and future of the framing perspective: 25+ years since 'Frame Alignment'. Mobilization, v. 19, n. 1, p. $23-46,2014$.

TARROW, S. Power in movement: social movements, collective action and politics. Nova York: Cambridge University Press, 1988.

UNITED NATIONS OFFICE ON DRUGS AND CRIME. Respostas à violência baseada em gênero no Cone Sul: avanços, desafios e experiências regionais. 2011. Disponível em: <http://www.unodc.org/ documents/lpo-brazil/Topics_crime/Publicacoes/Respostas_Violencia_ Genero_Cone_Sul_Port.pdf>.

VANHALA, L. Anti-discrimination Policy Actors and their use of Litigation Strategies: the influence of identity politics. Journal of European Public Policy, v. 16, p. 738-754, 2009. 


\section{4}

\section{OS PAPÉIS DA CORTE}

INTERAMERICANA DE

DIREITOS HUMANOS E

DA CORTE EUROPEIA DE

DIREITOS HUMANOS NO

ENFRENTAMENTO DA

VIOLÊNCIA DE GÊNERO'

Mariângela Gama de Magalhães Gomes

1 Esse artigo foi produzido durante a vigência de Bolsa de Pesquisa no Exterior concedida pela FAPESP, sendo um de seus resultados (processo no 2017/23808-4, Fundação de Amparo à Pesquisa do Estado de São Paulo - FAPESP). As opiniões, hipóteses e conclusões ou recomendações expressas neste artigo são de responsabilidade da autora e não necessariamente refletem a visão da FAPESP. 


\section{Introdução}

O enfrentamento das discriminações relacionadas ao gênero, e mais especificamente os problemas envolvendo a violência contra as mulheres, vem sendo feito, de forma paralela, pelos dois maiores sistemas regionais de proteção dos direitos humanos, quais sejam, os sistemas europeu e interamericano. Embora as realidades nas quais os órgãos de controle são chamados a atuar não sejam necessariamente semelhantes, é possível aferir certa convergência no que diz respeito à atribuição de responsabilidade aos Estados em função da ausência de proteção conferida às mulheres quando inseridas em contextos de vulnerabilidade.

O objetivo deste estudo é expor, ainda que de maneira sucinta, dois casos e suas respectivas soluções dadas pelos correspondentes órgãos regionais de proteção. Assim, serão analisados os casos Talpis contra a Itália e González e outras (Campo Algodoeiro) contra o México, julgados pela Corte Europeia de Direitos Humanos e Corte Interamericana de Direitos Humanos, respectivamente. Pretende-se, com isso, observar o papel desempenhado por estes dois importantes órgãos internacionais na proteção das mulheres frente a violações de seus direitos humanos.

Para tanto, serão feitas algumas considerações iniciais acerca do papel dos dois referidos órgãos na proteção aos direitos humanos, seguida pela descrição dos mencionados casos e, finalmente, realizar-se-á uma análise conjunta a fim de identificar o percurso que vem sendo feito nos dois continentes para que os direitos das mulheres sejam efetivamente tutelados e elas respeitadas em sua dignidade.

\section{Os sistemas regionais de proteção aos direitos humanos e seus principais órgãos de atuação}

O processo de proteção aos direitos humanos, universal e positivo, foi inaugurado com a Declaração Universal dos Direitos Humanos, aprovada pela Assembleia Geral das Nações Unidas em 10 de dezembro de 1948. A partir de então, passou-se a entender que todos os seres humanos são destinatários de tais direitos, independentemente do Estado ao 
qual pertençam, e sua proteção ocorre de maneira formal, reconhecendo-se sua tutela até mesmo contra o próprio Estado. (BOBBIO, 2004; MEZZETTI, 2010)

Nesse sentido, a comunidade internacional deixou de ser composta exclusivamente por Estados e organizações internacionais, podendo ser qualificada como comunidade universal dos homens. Nessa esfera, o direito internacional dos direitos humanos passou a assumir a mesma função que o direito constitucional exerce nos ordenamentos estatais, impondo regras que limitam a atuação dos ordenamentos nacionais, verdadeiros órgãos descentralizados da comunidade universal. Dessa forma, a Declaração Universal de Direitos do Homem, com seus princípios e valores juridicamente vinculantes, passou a apresentar-se como parâmetro para a avaliação da legitimidade dos comportamentos dos Estados e dos indivíduos, ao mesmo tempo em que assinala a posição do ser humano no centro da ordem jurídica. (MEZZETTI, 2010)

A esse primeiro documento internacional, fundamental para o desenvolvimento dos direitos, princípios e valores ali presentes, foi posteriormente acrescida uma pluralidade de tratados e convenções concebidas no âmbito das Nações Unidas, entre os quais se destacam os Pactos da ONU de 1966: o Pacto Internacional sobre Direitos Civis e Políticos (com seus Protocolos Opcionais de 1966 e 1989) e o Pacto Internacional sobre Direitos Econômicos, Sociais e Culturais (com seu Protocolo Opcional de 2008).

Não obstante todos os documentos internacionais de alcance universal, houve um significativo avanço no sentido de conferir efetiva tutela aos direitos humanos com a criação de sistemas regionais de proteção. Tais sistemas diferenciam-se do anterior, uma vez que suas normas obrigam exclusivamente os Estados pertencentes a uma determinada região geográfica. A partir do norte fixado pelas normas de caráter universal, os instrumentos regionais devem sempre procurar ampliar a proteção dos direitos humanos por meio da previsão de novas tutelas ou pelo reforço às garantias já conferidas de forma ampla, numa relação de complementaridade. (AMARAL JÚNIOR, 2013; PIOVESAN, 2003)

O primeiro documento regional criado - que serviu de inspiração para os posteriores - foi a Convenção Europeia de Direitos Humanos, de 
1950. Esta, além de conferir proteção a direitos já presentes em outros instrumentos, deu importante avanço ao prever um sistema de garantia jurisdicional para dotá-los de efetividade, composto por uma Comissão Permanente e uma Corte Europeia dos Direitos Humanos, às quais estava prevista a possibilidade de recebimento de petições individuais. (FRAGOSO, 1977)

Assim, se até aquele momento podiam ser observadas medidas de promoção e controle dos direitos humanos, como as contidas nos Pactos da ONU de 1966, dirigidas a promover o reforço dos sistemas jurídicos nacionais, a partir de então se deu a introdução de medidas de garantia, cujo objetivo era a criação de uma jurisdição nova e mais elevada, de uma verdadeira tutela judicial de alcance internacional, que substituísse a tutela nacional quando esta fosse insuficiente ou inexistente. Segundo Bobbio, a importância desta terceira modalidade de proteção está em que só é possível falar legitimamente de tutela internacional dos direitos humanos quando uma jurisdição internacional consegue impor-se e superporse às jurisdições nacionais, e quando se realiza a passagem da garantia dentro do Estado para a garantia contra o Estado. (BOBBIO, 2004)

$\mathrm{Na}$ América, por sua vez - embora em abril de 1948 já tivesse sido elaborada a Declaração Americana dos Direitos e Deveres Humanos, por ocasião da IX Conferência Internacional Americana ocorrida em Bogotá -, o Conselho da Organização dos Estados Americanos redigiu, em 1969, em São José da Costa Rica, a Convenção Americana de Direitos Humanos, ou Pacto de São José da Costa Rica, documento análogo à Convenção Europeia de Direitos Humanos. A importância desse documento foi ressaltada pela Corte Interamericana quando observou que seu objeto e fim são a proteção dos direitos fundamentais dos seres humanos, independentemente de sua nacionalidade, tanto frente ao próprio Estado como frente aos outros Estados contratantes. Ao aprovar este tratado, os Estados se submetem a uma ordem legal dentro da qual eles, pelo bem comum, assumem várias obrigações não em relação aos outros Estados, mas frente aos indivíduos sob sua jurisdição. ${ }^{2}$

2 Opinião Consultiva OC-2/82, de 24 de setembro de 1982, solicitada pela Comissão Interamericana de Direitos Humanos, §29. 
Nos moldes do que fora acordado no âmbito europeu, o artigo 33 da Convenção Americana previu órgãos cuja finalidade é conferir proteção efetiva aos direitos humanos enumerados, conhecendo de assuntos relacionados com o cumprimento dos compromissos assumidos pelos Estados-partes.

Com o tempo, ficou claro que a criação de tribunais aptos a analisar supostas violações ocorridas nos Estados sobre os quais têm jurisdição tornou-se a principal característica a destacar os sistemas regionais, cujos avanços foram facilitados pelo reduzido número de participantes e por possuírem um substrato cultural comum. (AMARAL JÚNIOR, 2013) Assim, ao iniciar o cumprimento das promessas quanto à efetividade da tutela dos direitos humanos, Garcia Ramírez constatou que a Convenção Europeia de Direitos Humanos inaugurou um novo capítulo da tutela jurídica internacional atinente à matéria. (GARCÍA RAMÍREZ, 2006)

Passadas algumas décadas desde que a Corte Europeia e a Corte Interamericana começaram a funcionar, sua importância para o sistema internacional de proteção dos direitos humanos é evidente, tendo ambas preponderante papel na definição dos direitos humanos tutelados nos dois continentes. Isso resta claro porque, nessa seara, são comuns a generalidade e a vagueza das disposições normativas internacionais, permitindo-se concluir que sua proteção é, naturalmente, muito mais um exercício de prudência judicial do que labor legislativo. (RAMOS, 2012)

Portanto, a relativa simplicidade das disposições convencionais pode dar a falsa ideia de que o conhecimento do seu texto é suficiente para a apreensão de seu significado. Ao contrário, as Convenções não podem ser adequadamente compreendidas sem que seja analisada a jurisprudência de seus órgãos de controle, e normas convencionais com conteúdo amplo, como é o direito à vida privada e familiar, por exemplo, são casos claros de direitos de criação jurisprudencial, cujos contornos atuais dificilmente poderiam ser adivinhados pelo intérprete há meio século. (BULTRINI, 2002; GARCÍA ROCA et al., 2012) Pode-se, assim, dizer que as Cartas de Direitos se assemelham a um hipertexto, e o catálogo de direitos e liberdades nelas reconhecido deve ser lido à luz das concretizações jurisprudenciais. (MANES, 2012) 


\section{Documentos internacionais voltados à proteção das mulheres}

Embora os documentos internacionais de caráter universal voltados à proteção dos direitos humanos não deixem de fazer referência, via de regra, à igualdade entre homens e mulheres e ao princípio da não discriminação, há que ser feita referência, aqui, a específicas convenções voltadas, essencialmente, à proteção das mulheres e eliminação de discriminações contra elas.

No âmbito das Nações Unidas, a Convenção sobre a Eliminação de Todas as Formas de Discriminação contra as Mulheres (CEDAW), de 1979, estabeleceu, entre outras coisas, a necessidade de que os Estados tomem as medidas necessárias para modificar os modelos de comportamento e eliminar preconceitos e práticas costumeiras fundadas na ideia de inferioridade ou de superioridade de um ou de outro sexo ou de um papel estereotipado dos homens e das mulheres (art. $\left.5^{\circ}, a\right)$. Nesse documento, os Estados comprometem-se, também, a proteger jurisdicionalmente os direitos das mulheres em pé de igualdade com os dos homens, garantindo a proteção efetiva das mulheres contra qualquer ato discriminatório, além de assegurar que suas autoridades e instituições públicas também não praticarão tais condutas discriminatórias ( $\operatorname{art} .2^{\mathrm{o}}, c \mathrm{e} d$ ).

O primeiro instrumento regional de proteção de direitos humanos voltado especificamente à proteção das mulheres frente à violência de gênero foi a Convenção Interamericana para Prevenir, Punir e Erradicar a Violência contra a Mulher, também conhecida como Convenção de Belém do Pará, de 1994. Ali, além de definir violência contra a mulher como "qualquer ato ou conduta baseada no gênero, que cause morte, dano ou sofrimento físico, sexual ou psicológico à mulher” ( $\left.\operatorname{art.} 1^{\circ}\right)$, a convenção deixa claro que tais atos se caracterizam independentemente de serem praticados na esfera familiar ou doméstica, em âmbito social ou, ainda, se a violência for perpetrada ou tolerada pelo Estado ou seus agentes, onde quer que ocorra (art. $2^{\circ}$ ). Mais do que isso, os Estados garantem absterem-se de qualquer ato ou prática de violência contra a mulher, assim como velarem para que suas autoridades e seus funcionários atuem 
de acordo com essa obrigação, comprometendo-se a agir com o devido zelo para prevenir, investigar e punir a violência contra a mulher (art. $7^{\circ}$, $a \mathrm{e} b)$.

No âmbito europeu, a Convenção do Conselho da Europa para a Prevenção e o Combate à Violência Contra as Mulheres e a Violência Doméstica, também conhecida como Convenção de Istambul, de 2011, parte do pressuposto de que a violência contra as mulheres é manifestação das relações de poder historicamente desiguais entre mulheres e homens, responsável pela dominação e discriminação das mulheres pelos homens, assim como reconhece que a natureza estrutural da violência contra as mulheres é baseada no gênero, sendo um dos mecanismos sociais cruciais através dos quais as mulheres são mantidas numa posição de subordinação em relação aos homens. Entre suas diretrizes encontrase não só o comprometimento dos Estados no sentido de não praticar qualquer ato de violência contra as mulheres, mas também de assegurar que suas autoridades, funcionários, agentes e instituições comportemse em conformidade com tal obrigação, o que implica tomar as medidas necessárias para prevenir, investigar, punir e proporcionar reparação às vítimas quando os atos forem praticados por particulares (art. $5^{\circ}, 1$ e 2).

A partir dessas considerações, e tendo em vista o relevante papel desempenhado pelos órgãos jurisdicionais dos sistemas europeu e interamericano de direitos humanos no que diz respeito à proteção da mulher frente à violência e à discriminação, serão a seguir expostos os casos González e outras (Campo Algodoeiro) contra o México e Talpis contra a Itália. O primeiro foi julgado pela Corte Interamericana de Direitos Humanos, em novembro de 2009, ao passo que o segundo foi objeto de decisão da Corte Europeia de Direitos Humanos, março de 2017. Em ambos deve ser dada atenção ao papel das autoridades estatais na eliminação da discriminação contra as mulheres e na prevenção da violência de gênero, nem sempre tão claras quando se fala na proteção dos direitos humanos das mulheres. 


\section{Breve descrição do Caso González e outras (Campo Algodoeiro) contra o México}

Os fatos que dizem respeito a esse caso ocorreram em Ciudad Juárez, localizada no México, próxima à fronteira com o Texas. Trata-se de uma cidade industrial - onde se desenvolveu a indústria da maquiagem -, com aproximadamente 1.200.000 habitantes à época dos fatos eque conta com intenso trânsito de migrantes, mexicanos e estrangeiros. Caracterizada por desigualdades sociais, a proximidade com a fronteira internacional contribuiu para o desenvolvimento de diversas formas de delinquência organizada, como o tráfico de drogas, de pessoas e de armas, além de lavagem de dinheiro - o que aumentou a insegurança e violência. ${ }^{3}$

Os fatos que deram ensejo a esse caso dizem respeito ao desaparecimento e morte das jovens Laura Berenice Ramos Monárrez, Claudia Ivette González e Esmeralda Herrera Monreal. A primeira tinha 17 anos e era estudante, sendo que a última notícia que se tinha dela era um telefonema dado a uma amiga no dia 22 de setembro de 2001, sábado, para dizer que estava pronta para ir a uma festa; no procedimento instaurado constava que desapareceu na terça-feira, 25 de setembro de 2001, sem que houvesse mais detalhes. A segunda tinha 20 anos e trabalhava numa empresa de maquiagem. Segundo uma amiga próxima, por ajudar a irmã a cuidar da filha menor, quase sempre chegava atrasada ao trabalho, sendo que, no dia 10 de outubro de 2001, chegou dois minutos atrasada e, por isso, foi impedida de entrar na empresa, desaparecendo no mesmo dia. A terceira, por sua vez, tinha 15 anos e desapareceu na segunda-feira, 29 de outubro de 2001, logo após sair da casa em que trabalhava como empregada doméstica. ${ }^{4}$

Nos três casos, quando as famílias se dirigiram à autoridade policial para noticiar o desaparecimento das jovens, foram informadas de que era necessário o transcurso de 72 horas após o desaparecimento para que fossem iniciadas as investigações. Perante a Corte Interamericana ficou demonstrado que nas primeiras 72 horas foram apenas registrados os

3 Caso González e outras (Campo Algodoeiro) contra o México, §113.

4 Caso González e outras (Campo Algodoeiro) contra o México, §§165a 168. 
desaparecimentos, colhidos os depoimentos de quem fez a comunicação e emitido ofício ao Programa de Atenção às Vítimas de Crimes. Além dessas providências burocráticas e formais, não houve ações no sentido de mobilizar o aparato estatal para a busca real e efetiva das vítimas. ${ }^{5}$

Mesmo após as primeiras 72 horas, é possível observar que as autoridades pouco se empenharam para solucionar os três desaparecimentos. Por exemplo, coube às mães das moças desaparecidas iniciar as investigações por conta própria, como distribuir panfletos nas ruas, divulgar o fato nos meios de comunicação e fazer buscas. Além disso, não foi dada atenção a possíveis pistas sobre o paradeiro das vítimas, sendo que as autoridades se limitavam a colher depoimentos sem utilizá-los para embasar qualquer investigação efetiva. No caso de Laura Ramos, não foram consideradas as informações sobre o rapaz com quem falava frequentemente ao telefone, lugares que frequentava, seus planos para a noite de seu desaparecimento, sobre um rapaz com quem trabalhava e outras pessoas que poderiam fornecer informações, assim como um homem com quem, segundo testemunhas, ela queria sair. Da mesma forma, não se deu atenção à informação dada pela mãe sobre várias chamadas telefônicas que recebeu nos dias posteriores ao seu desaparecimento, sendo que, numa delas, ela ouviu a voz de sua filha discutindo com alguém. Já no caso de Claudia González, não foram consideradas declarações que poderiam ajudar nas buscas pela jovem, como a informação sobre um rapaz com quem ela saía, um casal que parecia observá-la sempre que passava na rua e um colega de trabalho que a assediava. ${ }^{6}$

Tão ou mais sintomático da forma como as mulheres são consideradas naquele contexto é o tratamento dado pelas autoridades policiais aos familiares das vítimas quando a eles se dirigiam para noticiar o desaparecimento de mulheres. Segundo os parentes, as autoridades minimizavam os fatos ou os desacreditavam, sob o pretexto de que as moças estariam com o namorado; além disso, perguntavam, rotineiramente, sobre as preferências sexuais das vítimas. A mãe de Esmeralda Herrera, por exemplo,

6 Caso González e outras (Campo Algodoeiro) contra o México, §§182 a 194. 
ouviu do policial que sua filha não estava desaparecida, mas estaria com o namorado, e que se estava desaparecida era porque ela tinha procurado por isso, já que uma boa menina costuma ficar em casa. À mãe de Claudia González foi dito que era certeza de que a filha estaria com o namorado, porque as garotas em geral eram muito "dadas" e se atiravam aos homens, além de dizer que logo voltaria. Já para a mãe de Laura Ramos, as autoridades disseram que todas as garotas se perdem, querem fugir com o namorado ou viver a vida sozinhas. Uma vez, pediu aos policiais para acompanharem-na a um baile para procurar sua filha, ao que responderam que seria tarde demais e já estariam indo descansar. Dando-lhe um tapinha nas costas disseram para que "bebesse umas geladas à nossa saúde" porque não poderiam acompanhá-la.7

Apurou-se, ainda, que as autoridades decidiam se investigavam ou não os desaparecimentos de mulheres a partir do status que a vítima - a critério do investigador - tinha na sociedade. Significa que, se a mulher gostava de se divertir, sair para dançar, tinha amigos e uma vida social, era considerada corresponsável pelo que lhe aconteceu. Dessa forma, as autoridades estigmatizavam as vítimas de desaparecimento pelo fato de serem mulheres, o que ficava claro quando sugeriam que tivessem fugido com o namorado ou fossem "dadas", sendo que chegaram a culpar as mães por permitirem que suas filhas andassem sozinhas ou saíssem à noite. ${ }^{8}$

Expressão ainda mais clara da discriminação pelas autoridades em relação às mulheres desaparecidas está no fato de que a avaliação pessoal sobre o status da vítima transformou-se em política institucional levada a cabo pelos funcionários estatais, segundo a qual distinguiam "desaparecimentos de alto risco" dos demais casos. Os "desaparecimentos de alto risco" eram assim considerados a partir do comportamento das vítimas, de modo que só se encaixavam nessa categoria as mulheres que tivessem uma "rotina estável”, ou seja, uma “vida não reprovável'. A prova inconteste da discriminação e disfuncionalidade desse critério está no fato de que, segundo informe da Anistia Internacional, do total de 69

7 Caso González e outras (Campo Algodoeiro) contra o México, §§ 196 a 201, e 207.

8 Caso González e outras (Campo Algodoeiro) contra o México, § 202. 
desaparecimentos registrados em março de 2003 , apenas um foi considerado pelas autoridades como de "alto risco". 9

No dia 6 de novembro de 2001, os corpos das três mulheres até então desaparecidas foram encontrados num campo algodoeiro. A forma como se encontravam sugere, com alta probabilidade, que tenham sido violados e abusados sexualmente com extrema crueldade. ${ }^{10}$

Frente a esses fatos, e também porque no período de seis anos o Estado não havia avançado no esclarecimento dos fatos e sua responsabilidade, a Comissão Interamericana solicitou à Corte que declarasse que o Estado descumpriu sua obrigação de garantir o direito à vida das vítimas mediante a adoção de medidas para evitar suas mortes, incorrendo, desse modo, numa violação ao artigo $4^{\circ}$ da Convenção Americana de Direitos Humanos, em conexão com os artigos 1.1 e $2^{\circ}$ do mesmo tratado. ${ }^{11}$ Solicitou que declarasse que o Estado falhou em seu dever de atuar com a devida diligência para prevenir, investigar e sancionar os atos de violência sofridos pelas vítimas em contradição ao art. $7^{\circ}$ da Convenção de Belém do Pará. ${ }^{12}$ Além disso, sustentou que o Estado descumpriu sua obrigação de

9 Caso González e outras (Campo Algodoeiro) contra o México, §§ 204 a 208.

10 Caso González e outras (Campo Algodoeiro) contra o México, §§ 209 a 221.

11 De acordo com o art. 1.1, "Os Estados-partes nesta Convenção comprometem-se a respeitar os direitos e liberdades nela reconhecidos e a garantir seu livre e pleno exercício a toda pessoa que esteja sujeita à sua jurisdição, sem discriminação alguma, por motivo de raça, cor, sexo, idioma, religião, opiniões políticas ou de qualquer outra natureza, origem nacional ou social, posição econômica, nascimento ou qualquer outra condição social". O art. $2^{\circ}$, relativo ao dever de adotar disposições de direito interno, indica que "se o exercício dos direitos e liberdades mencionados no artigo 1 ainda não estiver garantido por disposições legislativas ou de outra natureza, os Estados-partes comprometem-se a adotar, de acordo com as suas normas constitucionais e com as disposições desta Convenção, as medidas legislativas ou de outra natureza que forem necessárias para tornar efetivos tais direitos e liberdades". O art. $4^{\circ}$, intitulado "Direito à vida", estabelece no item 1 que "toda pessoa tem o direito de que se respeite sua vida. Esse direito deve ser protegido pela lei e, em geral, desde o momento da concepção. Ninguém pode ser privado da vida arbitrariamente".

12 O art. $7^{\circ}$ da Convenção de Belém do Pará estabelece que "Os Estados Partes condenam todas as formas de violência contra a mulher e convêm em adotar, por todos os meios apropriados e sem demora, políticas destinadas a prevenir, punir e erradicar tal violência e a empenhar-se em: a. abster-se de qualquer ato ou prática de violência contra a mulher e velar por que as autoridades, seus funcionários e pessoal, bem como agentes e instituições públicos ajam de conformidade com essa obrigação; b. agir com o devido zelo para prevenir, investigar e punir a violência contra a mulher; c. incorporar na sua legislação interna normas penais, civis, admi- 
investigar efetiva e adequadamente o desaparecimento e posterior morte das jovens González, Herrera e Ramos, em violação aos artigos 8º 25 e 1.1 da Convenção Americana. ${ }^{13}$

Assim, as questões enfrentadas pela Corte Interamericana dizem respeito à caracterização dos crimes descritos como "violência contra a mulher", nos termos da Convenção de Belém do Pará, assim como a responsabilidade do Estado em relação a eles. Segundo a Comissão Interamericana e os representantes das vítimas, os homicídios analisados nesse caso são caracterizados por extrema crueldade, são crimes de ódio e misóginos, acompanhados de enorme tolerância social e estatal à violência genérica contra as mulheres. ${ }^{14}$

Quanto à primeira questão, embora a Corte já tivesse estabelecido que nem toda violação a um direito humano cometida contra uma mulher constitui necessariamente uma violação às disposições da Convenção de Belém do Pará, três características do caso concreto levam à conclusão de

nistrativas e de outra natureza, que sejam necessárias para prevenir, punir e erradicar a violência contra a mulher, bem como adotar as medidas administrativas adequadas que forem aplicáveis; d. adotar medidas jurídicas que exijam do agressor que se abstenha de perseguir, intimidar e ameaçar a mulher ou de fazer uso de qualquer método que danifique ou ponha em perigo sua vida ou integridade ou danifique sua propriedade; e. tomar todas as medidas adequadas, inclusive legislativas, para modificar ou abolir leis e regulamentos vigentes ou modificar práticas jurídicas ou consuetudinárias que respaldem a persistência e a tolerância da violência contra a mulher; f. estabelecer procedimentos jurídicos justos e eficazes para a mulher sujeitada a violência, inclusive, entre outros, medidas de proteção, juízo oportuno e efetivo acesso a tais processos; $g$. estabelecer mecanismos judiciais e administrativos necessários para assegurar que a mulher sujeitada a violência tenha efetivo acesso a restituição, reparação do dano e outros meios de compensação justos e eficazes; $h$. adotar as medidas legislativas ou de outra natureza necessárias à vigência desta Convenção".

13 Caso González e outras (Campo Algodoeiro) contra o México, § 109. Quanto à Convenção Americana de Direitos Humanos, seu art. $8^{\circ}$ estabelece as garantias judiciais asseguradas a todos os acusados e o art. 25 estabelece que "1. Toda pessoa tem direito a um recurso simples e rápido ou a qualquer outro recurso efetivo, perante os juízes ou tribunais competentes, que a proteja contra atos que violem seus direitos fundamentais reconhecidos pela Constituição, pela lei ou pela presente Convenção, mesmo quando tal violação seja cometida por pessoas que estejam atuando no exercício de suas funções oficiais. 2. Os Estados-partes comprometem-se: a) a assegurar que a autoridade competente prevista pelo sistema legal do Estado decida sobre os direitos de toda pessoa que interpuser tal recurso; b) a desenvolver as possibilidades de recurso judicial; e c) a assegurar o cumprimento, pelas autoridades competentes, de toda decisão em que se tenha considerado procedente o recurso".

Caso González e outras (Campo Algodoeiro) contra o México, § 222. 
que se tratar de violência de gênero, nos termos do referido documento internacional.

Em primeiro lugar, o próprio Estado reconheceu a situação de violência contra a mulher na Ciudad Juárez, atrelando a crueldade dos homicídios contra as mulheres à influência de uma cultura de discriminação contra a mulher. Os informes da Comissão Interamericana de Direitos Humanos, da CEDAW e da Anistia Internacional, entre outros, indicam que muitos homicídios contra as mulheres naquela cidade são manifestações de violência baseada no gênero: as três vítimas do presente caso eram mulheres jovens, de poucos recursos, trabalhadoras ou estudantes, como muitas das vítimas dos homicídios ocorridos em Ciudad Juárez. Elas ficaram desaparecidas e seus corpos foram encontrados num campo algodoeiro, tendo sido provado que sofreram graves agressões físicas e muito provavelmente violência sexual antes de serem mortas. ${ }^{15}$

Quanto à atribuição de responsabilidade ao Estado pela morte das três vítimas, é preciso lembrar que, segundo a jurisprudência da Corte Interamericana, a obrigação de garantia dos direitos humanos pode ser cumprida de diferentes maneiras, em função do específico direito a ser garantido e de suas particulares necessidades de proteção. Isso implica o dever dos Estados de organizar todo o aparato governamental de modo a ser capaz de assegurar juridicamente o livre e pleno exercício dos direitos humanos. Faz parte de tal obrigação prevenir, razoavelmente, as violações a direitos humanos, investigar seriamente, com os meios a seu alcance, as violações praticadas em sua jurisdição a fim de identificar os responsáveis, aplicar as devidas sanções e proporcionar às vítimas a adequada reparação. É fundamental identificar se uma determinada violação ocorreu com apoio ou tolerância do poder público ou se este atuou de modo falho na sua prevenção ou repressão. ${ }^{16}$

Nesse sentido, a Corte recorda que a observância ao artigo $4^{\circ}$, relacionado ao artigo 1.1 da Convenção Americana, não só pressupõe que ninguém seja privado de sua vida arbitrariamente (obrigação negativa),

15 Caso González e outras (Campo Algodoeiro) contra o México, §§ 227 a 230.

16 Caso González e outras (Campo Algodoeiro) contra o México, § 236. 
mas também requer que os Estados adotem todas as medidas apropriadas para proteger e preservar o direito à vida (obrigação positiva), conforme o dever de garantir o pleno e livre exercício dos direitos de todas as pessoas sob sua jurisdição. Em relação à obrigação de garantir o direito reconhecido no $\operatorname{artigo~} 5^{\circ}$ da Convenção Americana, cabe ao Estado prevenir e investigar possíveis atos de tortura ou outros tratamentos cruéis, desumanos ou degradantes praticados em seu território. ${ }^{17}$

Com base em informes de órgãos internacionais de proteção dos direitos humanos, é possível constatar que, à época dos crimes descritos, a inexistência de políticas e medidas voltadas à prevenção, investigação e punição da violência contra a mulher permitiram que preponderasse uma cultura de impunidade e fosse provocada considerável sensação de insegurança em muitas mulheres de Ciudad Juárez. Não obstante essa conclusão, a Corte Interamericana considerou que a responsabilidade internacional do México restou caracterizada apenas a partir do desaparecimento das vítimas, quando o Estado teve conhecimento de que existia um risco real e imediato de que as moças fossem sexualmente violadas e assassinadas. Ao serem procuradas pelas famílias das vítimas, as autoridades deveriam ter realizado todas as diligências necessárias a esclarecer o desaparecimento de mulheres, especialmente nas primeiras horas e primeiros dias. Também deveriam ter sido realizadas exaustivas buscas, uma vez que deveriam presumir que a pessoa desaparecida estivesse com vida, privada de liberdade. No entanto, além de ter o Estado se limitado a realizar meras formalidades e tomar declarações inúteis, que não levaram a posteriores investigações, o comportamento de seus funcionários levou a demoras injustificadas, em total desacordo com a gravidade dos casos concretos, o que é agravado pela situação de especial vulnerabilidade das mulheres, circunstância conhecida pelo Estado. ${ }^{18}$

17 Caso González e outras (Campo Algodoeiro) contra o México, §§ 245 e 246. O art. $5^{\circ}$ da Convenção Americana, intitulado "Direito à integridade pessoal", estabelece que "1. Toda pessoa tem direito a que se respeite sua integridade física, psíquica e moral. 2. Ninguém deve ser submetido a torturas, nem a penas ou tratos cruéis, desumanos ou degradantes. Toda pessoa privada de liberdade deve ser tratada com o respeito devido à dignidade inerente ao ser humano $[\ldots .$.$] ".$

Caso González e outras (Campo Algodoeiro) contra o México, §§ 249 a 285. 
Em razão do que foi aqui exposto, a Corte Interamericana de Direitos Humanos considerou o Estado responsável pela violação dos direitos à vida, integridade física e liberdade pessoal reconhecidos nos artigos 4.1, 5.1, 5.2 e 7.1 da Convenção Americana, em relação com a obrigação geral de garantia, contemplada no art. 1.1, a obrigação de adotar disposições de direito interno, contemplada no art. $2^{\circ}$ do mesmo documento e as obrigações dispostas nos artigos 7.b e 7.c da Convenção de Belém do Pará, pelos crimes praticados contra as três mulheres acima referidas. ${ }^{19}$

\section{Breve descrição do caso Talpis contra a Itália}

No dia 2 de junho de 2012, Elizaveta Talpis chamou a polícia em sua casa porque seu marido, um alcoólatra que costumava agredi-la fisicamente já há bastante tempo, havia agredido a ela e também a sua filha. Com a chegada dos policiais, o marido, A.T., deixou a casa da família, e foi elaborado boletim de ocorrência em que constou que Elizaveta fora espancada e mordida no rosto e na perna esquerda, além de ter várias contusões, enquanto a filha, ao intervir para defender a mãe, foi igualmente agredida e apresentava ferimentos no pescoço e nos dois braços. Mãe e filha não foram informadas sobre a possibilidade de darem início à investigação criminal ou de contatarem um centro para mulheres vítimas de violência. Elas se dirigiram à sala de emergência para relatar seus ferimentos, mas, depois de três horas sem serem atendidas, decidiram voltar para casa. ${ }^{20}$

Após esse evento, a esposa de A.T. passou a dormir no porão de sua casa, para se proteger de futuras agressões. No dia 19 de agosto de 2012, depois de um telefonema ameaçador do marido e constatar o portão da casa quebrado, ela procurou um amigo para abrigá-la durante a noite, mas sua ligação não foi atendida e decidiu voltar para casa. Ali, A.T. a atacou com uma faca e a obrigou a segui-lo para ter relações sexuais com seus amigos. Embora no caminho ela tenha pedido ajuda à polícia que patrulhava a região, os policiais limitaram-se a verificar seus documentos de

Caso González e outras (Campo Algodoeiro) contra o México, § 286.

Caso Talpis contra a Itália, §§ 9 a 11. 
identidade e os de A.T., e, apesar de ela ter dito que havia sido ameaçada e machucada pelo marido, apenas sugeriram que ela voltasse para casa e pediram para o marido afastar-se dela. Após chegar em casa, Elizaveta telefonou à emergência e foi levada ao hospital, onde os médicos observaram, entre outras coisas, que ela sofrera traumatismo craniano, ferimento na cabeça, várias escoriações no corpo e hematoma no peito. ${ }^{21}$

No hospital, ao ser ouvida por assistente social, a vítima declarou não querer voltar à casa, razão pela qual foi abrigada numa associação de proteção a mulheres vítimas de violência. Em 5 de setembro de 2012, ela formalizou acusação contra o marido, relatando a prática de lesões corporais, maus-tratos e ameaças. Pediu às autoridades que tomassem medidas urgentes para protegê-la e também proteger seus filhos, evitando que A.T. se aproximasse deles, e informou que A.T. continuava a assediá-la por telefone. $^{22}$

Foi iniciada uma investigação criminal contra o A.T. por abuso familiar, lesões corporais agravadas e ameaças, sendo que a polícia encaminhou o procedimento ao Ministério Público, em 9 de outubro de 2012. Tendo em vista o pedido de medidas protetivas, foram determinadas medidas urgentes de investigação em 15 de outubro de $2012 .{ }^{23}$

Ocorre, entretanto, que, após três meses de acolhimento na associação de proteção a mulheres, o funcionário dos serviços sociais da localidade em que se encontrava (Udine) informou àquela instituição que não mais havia fundos disponíveis para bancar a vítima ou fornecer-lhe outra solução de acomodação. ${ }^{24}$ Assim, no dia 4 de dezembro de 2012, Elizaveta deixou o abrigo para procurar trabalho. Após dormir na rua e ser abrigada por amigos, começou a trabalhar como cuidadora de idosos e chegou a

\footnotetext{
21 Caso Talpis contra a ltália, §§13a16.

22 Caso Talpis contra a Itália, §§ 18 a 21.

23 Caso Talpis contra a ltália, §§ 22 a 24.

24 Segundo o Estado italiano, uma vez que a vítima não foi inicialmente apoiada pelos serviços sociais da Câmara Municipal de Udine, que tratava de vítimas de violência em outro projeto, chamado "Tolerância Zero", a associação não poderia receber os recursos necessários para acolhê-la. Além disso, as mulheres vítimas de violência podem contatar os serviços sociais para pedir ajuda, o que a solicitante não teria feito. Caso Talpis contra a ltália, § 26.
} 
alugar um apartamento, embora durante todo o tempo sofresse pressão psicológica por parte de A.T. para que retirasse a "queixa". ${ }^{25}$

Diante da inércia da polícia, o Ministério Público solicitou, novamente, em 18 de março de 2013, que fossem feitas as investigações do caso. Foi, no entanto, somente em 4 de abril - sete meses após a apresentação da "queixa" - que a vítima foi ouvida pela primeira vez pela polícia, momento em que amenizou a gravidade dos fatos. Em relação ao episódio de junho de 2012, afirmou que o marido havia tentado bater nela, mas não tinha efetivamente batido, assim como sua filha não havia sido espancada. Quanto aos fatos de agosto do mesmo ano, disse que de fato apanhou, mas não fora ameaçada com faca; disse, também, que à época não falava bem o italiano e, por isso, expressou-se mal, afirmando que o marido não a forçou a ter relações sexuais com outras pessoas. Disse ter voltado a morar na casa com a família, que não falou com o marido ao telefone enquanto esteve abrigada na associação e assegurou que, exceto pelo alcoolismo de A.T., ele era bom pai e bom marido, a situação em casa estava calma, sem a ocorrência de outros episódios de violência. ${ }^{26}$

Frente a esse depoimento, em decisão de $1^{\circ}$ de agosto de 2013 , não foi considerada caracterizada a infração de "abuso familiar" por parte de A.T., por não ter sido verificada a repetição de episódios de violência. Quanto à ameaça agravada pelo uso de arma, as declarações da vítima foram tidas como contraditórias, sendo que, no relatório hospitalar, não havia referência a ferimentos causados por faca. ${ }^{27}$

No que se refere às lesões corporais praticadas em agosto de 2012, A.T. recebeu, no dia 18 de novembro de 2013, notificação de audiência perante o Juiz de Paz marcada para maio de $2014{ }^{28}$

Uma semana depois, na noite de 25 de novembro de 2013, Elizaveta solicitou intervenção policial devido a uma discussão com o marido. Ao chegarem à sua casa, os policiais encontraram a porta da casa quebrada e

25 Caso Talpis contra a Itália, §§ 24 a 28.

26 Caso Talpis contra a Itália, §§ 29 e 30.

27 Caso Talpis contra a Itália, §§32 a 34.

28 Caso Talpis contra a Itália, §36. 
o chão coberto de garrafas de bebida alcoólica. A vítima afirmou que o marido estava sob a influência de álcool e que ela decidira pedir ajuda porque achava que ele precisava de um médico. O filho do casal afirmou que seu pai não era violento, e tanto ele como a mãe não apresentavam sinais de violência. ${ }^{29}$

A.T., por sua vez, embora tenha sido levado ao hospital, evadiu-se de lá durante a noite. Ao caminhar na rua de volta para casa, durante a madrugada, ele foi parado pela polícia para verificação de identidade, quando foi registrado pela autoridade seu estado de embriaguez e dificuldade para equilibrar-se, foi advertido e liberado em seguida. ${ }^{30}$ Às 5 horas da manhã, A.T. entrou no apartamento da família, armado com uma faca de cozinha, com a intenção de matar Elizaveta. Para impedir esse fato, o filho do casal tentou segurar seu pai, momento em que foi esfaqueado três vezes e, em seguida, morreu. Elizaveta tentou fugir, mas A.T. a seguiu e conseguiu segurá-la, esfaqueando-a várias vezes no peito; ela, no entanto, não morreu..$^{31}$

Em janeiro de 2015, A.T. foi condenado à prisão perpétua e indenização no valor de 400.000 euros pelo homicídio de seu filho e tentativa de homicídio da sua esposa, além dos maus-tratos à família. Apurou-se, no processo, que Elizaveta e seus filhos viviam num clima de constante violência, em que eram habituais agressões e ameaças. A mudança nas declarações iniciais da esposa sobre o comportamento de A.T. foi decorrente da pressão psicológica sofrida por ela: A.T. sentia ódio da esposa, e os crimes praticados em 25 de novembro de 2013 tiveram como causa a tentativa de Elizaveta de afastar-se do marido. ${ }^{32}$

Apesar da condenação de A.T., Elizaveta dirigiu-se à Corte Europeia de Direitos Humanos e alegou que, por sua inércia e indiferença, as autoridades italianas, embora conscientes da violência doméstica da qual era vítima, não tomaram as medidas necessárias e adequadas para proteger

29 Caso Talpis contra a Itália, §§ 37 e 38.

30 Caso Talpis contra a Itália, §§39a 41.

31 Caso Talpis contra a Itália, $\$ 42$.

32 Caso Talpis contra a Itália, §§31, 46 e 47. 
sua vida e a de seu filho, acusando a Itália da violação dos artigos $2^{\circ}, 3^{\circ}$ e $8^{\circ}$ da Convenção Europeia de Direitos Humanos. ${ }^{33}$

Ao julgar o caso, a Corte Europeia lembrou que, entre as obrigações positivas impostas aos Estados pela Convenção - o que inclui os artigos $2^{\mathrm{o}}, 3^{\mathrm{o}}$ e $8^{\mathrm{o}}-$, encontra-se o dever de estabelecer e aplicar um arcabouço legal apropriado a fornecer proteção contra atos de violência. ${ }^{34}$

No que diz respeito à proteção da vida, além da evidente lesão sofrida pelo filho da requerente, ela própria também pode ser considerada desprotegida nos termos da Convenção, uma vez que teve sua vida exposta a perigo. Embora a violência exercida contra ela não tenha sido letal, a interpretação dada ao art. $2^{\circ}$ da Convenção Europeia inclui casos em que o uso da força pode involuntariamente causar a morte da vítima. Isso porque a primeira sentença do art. $2^{\circ}, \S 1^{\circ}$, impõe ao Estado não só se abster de causar a morte de forma voluntária e ilícita, mas também o obriga a tomar as medidas necessárias para proteger a vida das pessoas sob sua jurisdição. ${ }^{35}$

No contexto específico da violência doméstica, as medidas de proteção são concebidas para evitar o mais rapidamente possível uma situação de perigo - e isso foi claramente desconsiderado quando se constata que

33 Caso Talpis contraa Itália, §76. De acordo com o art. 20, intitulado "Direito à vida”, "1. O direito de qualquer pessoa à vida é protegido pela lei. Ninguém poderá ser intencionalmente privado da vida, salvo em execução de uma sentença capital pronunciada por um tribunal, no caso de o crime ser punido com esta pena pela lei. 2. Não haverá violação do presente artigo quando a morte resulte de recurso à força, tornado absolutamente necessário: a) Para assegurar a defesa de qualquer pessoa contra uma violência ilegal; b) Para efectuar uma detenção legal ou para impedir a evasão de uma pessoa detida legalmente; c) Para reprimir, em conformidade com a lei, uma revolta ou uma insurreição". O art. $3^{\circ}$, intitulado "Proibição da tortura", estabelece que "Ninguém pode ser submetido a torturas, nem a penas ou tratamentos desumanos ou degradantes". O art. $8^{\circ}$, intitulado "Direito ao respeito pela vida privada e familiar", estabelece: "1. Qualquer pessoa tem direito ao respeito da sua vida privada e familiar, do seu domicílio e da sua correspondência. 2. Não pode haver ingerência da autoridade pública no exercício deste direito senão quando esta ingerência estiver prevista na lei e constituir uma providência que, numa sociedade democrática, seja necessária para a segurança nacional, para a segurança pública, para o bem - estar económico do país, a defesa da ordem e a prevenção das infracções penais, a protecção da saúde ou da moral, ou a protecção dos direitos e das liberdades de terceiros".

Caso Talpis contra a Itália, §100.

Caso Talpis contra a Itália, §§ 107 a 110. São citados pela Corte Europeia, como precedentes, os casos Makaratzis contra a Grécia, $\S \S 49-55$, LCB contra o Reino Unido, $\S 36$, e Osman contra o Reino Unido, §§ 115-122, 
a requerente somente foi ouvida pelas autoridades sete meses após ter levado a conhecimento as agressões sofridas. Para a Corte Europeia, tal atraso a privou da proteção imediata exigida pela situação, independentemente de, no período em questão, ela não ter sido vítima de outros atos de violência física por parte de A.T. Os juízes de Estrasburgo consideraram que não poderia ser ignorado o sentimento de medo em que a vítima vivia, sendo assediada diariamente por telefone enquanto estava no centro de proteção..$^{36}$

Para a Corte, ao não agirem rapidamente após a serem informadas das agressões pela vítima, as autoridades italianas deixaram a "queixa" sem eficácia, criando um contexto favorável à impunidade de A.T. pelos repetidos atos de violência contra sua família. Observou-se que, na noite de 25 de novembro de 2013, as autoridades policiais foram alertadas duas vezes sobre o estado de embriaguez do agressor, e em nenhuma das oportunidades ofereceram proteção adequada à requerente, embora soubessem que já houvera violência doméstica no seio daquela família e ainda estava pendente de apuração um procedimento relativo a lesões corporais praticadas por A.T. contra Elizaveta. ${ }^{37}$

Na opinião da Corte Europeia de Direitos Humanos, o risco de ameaça real e imediata deve ser avaliado no contexto específico da violência doméstica, caracterizado por sucessivos episódios de agressão que se repetem ao longo do tempo dentro da unidade familiar. Assim, a conclusão foi no sentido de que as autoridades nacionais não atuaram com a devida diligência, falhando na sua obrigação positiva de proteger a vida da requerente e de seu filho, motivo pelo qual a Itália foi condenada por violação ao art. $2^{\mathrm{o}}$ da Convenção Europeia..$^{38}$

Com relação à suposta violação do art. $3^{0}$ da Convenção Europeia, a Corte observou que a violência infligida à requerente resultou em lesões corporais e pressão psicológica suficientemente graves para serem qualificadas como maus-tratos, na acepção do art. $3^{\circ}$. A dúvida que podia haver

\footnotetext{
36 Caso Talpis contraa Itália, §114.

37 Caso Talpis contra a Itália, §§117 120.

38 Caso Talpis contra a Itália, §§122 a 125.
} 
dizia respeito, então, à contribuição das autoridades para referida violação, a fim de apurar a responsabilidade do Estado. ${ }^{39}$

A Corte Europeia reiterou, nesse ponto, a diligência especial necessária ao tratamento das apurações de violência doméstica, consideradas suas especificidades, como consta no preâmbulo da Convenção de Istambul. Por esse documento, os Estados devem tomar as medidas legislativas e outras necessárias para assegurar que as investigações e os procedimentos judiciais referentes à matéria não padeçam de demora injustificada, tendo em vista os direitos das vítimas em todas as fases do processo. De acordo com a argumentação da Corte, no tratamento judicial dos casos envolvendo violência doméstica contra mulheres, as autoridades nacionais devem levar em consideração a situação precária e a vulnerabilidade particular, moral, física e/ou material da vítima, de modo a tomar as providências necessárias o mais rápido possível. ${ }^{\circ}$

No caso analisado, foi considerada inexplicável a passividade das autoridades estatais durante período tão longo - sete meses - antes do início do processo penal. Da mesma forma, nada explica o motivo do processo por lesões corporais graves, praticadas em 2012, ter durado três anos, terminando em $1^{\mathrm{o}}$ de outubro de 2015 , com a condenação de A.T. à multa de 2.000 euros. $^{41}$

Diante desses fatos e argumentos, a Itália também foi condenada por violar o artigo $3^{\circ}$ da Convenção Europeia. ${ }^{42}$

Por fim, a Corte Europeia analisou a violação ao artigo 14 da Convenção Europeia de Direitos Humanos, que protege os indivíduos contra discriminação em razão do sexo, entre outras hipóteses. ${ }^{43}$ Isso porque, segundo a requerente, a omissão das autoridades italianas demonstra discriminação

39 Caso Talpis contra a ltália, §126.

40 Caso Talpis contra a Itália, §§129 e 130.

41 Caso Talpis contra a ltália, $\$ \S 35$ e 130.

42 Caso Talpis contraa Itália, §§131 e 132.

43 O art. 14, intitulado "Proibição de discriminação", estabelece que "O gozo dos direitos eliberdades reconhecidos na presente Convenção deve ser assegurado sem quaisquer distinções, tais como as fundadas no sexo, raça, cor, língua, religião, opiniões políticas ou outras, a origem nacional ou social, a pertença a uma minoria nacional, a riqueza, o nascimento ou qualquer outra situação". 
à mulher $\mathrm{e}$, ainda, que o aparato legislativo nacional para combater a violência doméstica não está apropriado para protegê-la. ${ }^{44}$

Nesse ponto, a Corte recordou sua jurisprudência no sentido de que o fracasso, ainda que involuntário, de um Estado na sua obrigação de proteger mulheres contra a violência doméstica constitui violação do direito das mulheres à igual proteção perante a lei. Assim, a passividade generalizada e discriminatória da polícia cria um clima propício à reiteração dessa violência, razão pela qual viola o artigo 14 da Convenção. Além disso, tal tratamento discriminatório pelas autoridades não deve ser caracterizado como mero fracasso ou atraso no tratamento da violência de gênero, mas repetidas tolerâncias em relação a estes fatos pelo fato da vítima ser uma mulher em situação de violência doméstica. Em outras palavras, ao subestimarem, pela sua inércia, a gravidade dos fatos levados a seu conhecimento, as autoridades apoiam sua prática. ${ }^{45}$

Nestes termos, a Itália foi também condenada por violar o artigo 14 da Convenção Europeia de Direitos Humanos, em conexão com os artigos $2^{\circ} \mathrm{e}$ $3^{\mathrm{O}} \cdot \cdot^{46}$

\section{Considerações sobre a importância dos sistemas regionais de proteção dos direitos humanos das mulheres frente às omissões dos estados}

As duas decisões descritas, em que pese se relacionarem a fatos praticados em contextos claramente diferentes, são convergentes na medida em que os Estados foram condenados pelo mesmo motivo: as autoridades encarregadas de promover a proteção das mulheres frente a agressões decorrentes das relações de gênero foram omissas no cumprimento de seus deveres.

\footnotetext{
44 Caso Talpis contra a Itália, §133.

45 Caso Talpis contra a Itália, §§ 141 e 145. Na decisão, são citados os seguintes precedentes: Opuz contra a Turquia, §§191 e ss.; Eremia contra a República da Moldávia, §§ 89 e 98; T. M. e C. M. contra a República da Moldávia, §62; Mudric contra a República da Moldávia, §63.

46

Caso Talpis contra a Itália, §§ 148 e 149.
} 
Nesse contexto, algumas considerações podem ser feitas com o intuito de sublinhar o papel das cortes regionais de direitos humanos para a proteção das mulheres frente à violência de gênero e apontar rumos para o melhor desempenho de tais atividades.

É importante destacar a liderança da Corte Interamericana de Direitos Humanos nessa matéria. Ao reconhecer os crimes praticados em Ciudad Juárez como expressão da violência de gênero contra as mulheres, no caso Campo Algodoeiro, a corte declarou, pela primeira vez na história do direito internacional dos direitos humanos, a responsabilidade de um Estado por não haver atuado com a devida diligência para a prevenção, punição e eliminação de todas as formas de violência contra as mulheres. (MERLI, 2015)

Aliás, quando se observa o que de fato estava subjacente às relações humanas estabelecidas naquela região, vê-se com clareza a conotação social, cultural e política que cercam os crimes contras as mulheres baseados em relações assimétricas de gênero. $\mathrm{O}$ caso aqui analisado expõe alguns dos mais aviltantes exemplos de violações a direitos humanos das mulheres, também presentes em inúmeros outros ambientes ao redor do mundo e capazes de escancarar tanto a impotência institucional como a cumplicidade cultural machista que permeiam o drama da violência de gênero. (MERLI, 2015)

Já no caso italiano, em que pese o contexto dos fatos ser outro, a pouca atenção dada pelas autoridades estatais às características da violência de gênero e à necessidade de serem empenhados cuidados específicos à sua prevenção foi responsável por não impedir que um marido fortemente alcoolizado e com histórico de agressões à esposa pudesse voltar para sua casa em tais condições. Se neste caso a cultura machista institucional não é tão evidente como no caso mexicano, sua sutileza é igualmente prejudicial aos direitos das mulheres, que se encontram sob a jurisdição do Estado, independentemente da consciência que os agentes estatais tenham em relação a ela.

Embora tanto a Corte Interamericana como a Europeia tenham julgado diversos outros casos envolvendo violência de gênero como espécie de violação a direitos humanos, a análise conjunta dos dois casos estudados 
neste capítulo ilustra como a cultura do domínio do homem sobre a mulher pode levar a diferentes formas de abusos e agressões.

Essa diversidade dos modos de violência de gênero põe em evidência o destacado papel das cortes regionais de proteção dos direitos humanos para a proteção das mulheres. Uma vez que os comportamentos não podem ser apartados dos sistemas de cultura e das organizações sociais em que historicamente surgem, marcados por hábitos, costumes e crenças, verifica-se o crescimento de uma tendência à "regionalização" dos instrumentos para seu enfrentamento. Assim, a partir de diretrizes internacionais, a atuação das Cortes Interamericana e Europeia de Direitos Humanos permite aproximar-se da questão da tutela dos direitos das mulheres e, particularmente, do combate à violência de gênero sob uma ótica local que facilite a adoção das iniciativas mais úteis ao enfrentamento do fenômeno no âmbito regional, com medidas mais eficazes frente a formas de violência que são social e culturalmente determinadas. (MERLI, 2015)

\section{Conclusões}

No processo de afirmação e desenvolvimento dos direitos humanos nos ordenamentos jurídicos internacional e nacionais, são de grande importância as Convenções Europeia e Interamericana de Direitos Humanos, assim como seus respectivos órgãos jurisdicionais encarregados de proteger referidos direitos.

Quanto à tutela dos direitos das mulheres frente à violência de gênero, merecem destaque a Convenção de Belém do Pará, de 1994, e a Convenção de Istambul, de 2011. A primeira foi criada no âmbito do sistema interamericano de proteção dos direitos humanos, ao passo que a segunda se insere no equivalente sistema europeu.

O caso Campo Algodoeiro contra o México, julgado em 2009 pela Corte Interamericana, e o caso Talpis contra a Itália, julgado em 2017 pela Corte Europeia, são dois exemplos de responsabilização internacional dos Estados por terem falhado na prevenção da violência de gênero. Embora os contextos sejam diferentes, em ambos se verifica como a cultura machista se encontra presente nas instituições estatais e colocam as 
mulheres em situação de ainda maior vulnerabilidade quando necessitam da proteção das autoridades frente às agressões sofridas apenas pelo fato de serem mulheres.

Tendo em vista os casos de violência de gênero se encontrarem amparados pelo contexto social em que ocorrem, sua eliminação demanda mudança de cultura e valores, o que não ocorre de uma hora para a outra. No entanto, a regionalização do enfrentamento do problema pode facilitar essa tarefa, razão pela qual as cortes regionais de proteção dos direitos humanos têm um papel fundamental em seus respectivos âmbitos de atuação.

\section{Referências}

AMARAL JÚNIOR, A. Curso de Direito Internacional Público. 4. ed. São Paulo: Atlas, 2013.

BOBBIO, N. A era dos direitos. Trad. Carlos Nelson Coutinho; apres. Celso Lafer. Rio de Janeiro: Elsevier, 2004.

BULTRINI, A. Il meccanismo di protezione dei diritti fondamentaliisti tuito dalla Convenzione Europea dei DirittiDell'Uomo.

Cenniintroduttivi. In: NASCIMBENE, B. (a cura di). La Convenzione

Europea dei Diritti Dell'Uomo: Profiliedeffettinell'ordinamento italiano.

Milano: Giuffrè, 2002.p. 3-53.

FRAGOSO, H. C. Direito penal e direitos humanos. Rio de Janeiro: Forense, 1977.

GARCÍA RAMÍREZ, S. Conferência proferida ao receber o Doctorado Honoris Causa da Universidade Argentina John F. Kennedy, em Buenos Aires, em 7 de abril de 2006. Disponível em: <www.ucipfg.com/ Repositorio/MCSH/MCSH-o1/Unidad_4/lecturas-Complementarias/ Derechos_Humanos_y_Jurisdiccion_Interamericana_Sergio_Ramirez. pdf $>$. Acesso em: 21 jan. 2015.

GARCÍA ROCA, J.; NOGUEIRA ALCALÁ, H.; BUSTOS GISBERT, R. La comunicación entre ambos sistemas y las características del diálogo. In: GARCÍA ROCA, J. (Ed.). El Diálogo entre los Sistemas Europeo y Americano de Derechos Humanos. Madrid: Civitas, 2012. p. 65-107. 
MANES, V. Diritto penale e fontisovranazionali. In: INSOLERA, Gaetano et al. Introduzione al sistema penale. 4. ed. Torino: G. Giappichelli Editore, 2012.v. 1. p. 157-223.

MERLI, A. Violenzadigenere e feminicídio. Diritto Penal e Contemporaneo, n. 1,2015.

MEZZETTI, L. Human Rights. Bologna: Bononia Universtity Press, 2010.

PIOVESAN, F. C. Direitos Humanos e a Jurisdição Constitucional Internacional. Revista Brasileira de Direito Constitucional, n. 1, p. 147-161, jan.jjul. 2003 .

RAMOS, A. de C. Teoria geral dos direitos humanos na ordem internacional. 2. ed. São Paulo: Saraiva, 2012. 


\section{A RESPONSABILIDADE DO} ESTADO BRASILEIRO NO CASO ALYNE PIMENTEL PELO CEDAW: mortalidade materna e direitos reprodutivos sob a ótica das críticas feministas aos direitos humanos

Flávia de Ávila,

Paula Alves Seixas e Karyna Batista Sposato 


\section{Introdução}

O desenvolvimento teórico acerca das relações entre as macroestruturas de poder e o controle social exercido sobre os indivíduos ao longo do último século demonstrou que a condição feminina dentro das sociedades está intimamente ligada à vigilância de seus corpos, de sua sexualidade e dos processos de reprodução. (EMMERICK, 2007) Desde o início, ainda no século XIX, o ativismo feminista apresentou a autonomia corporal como uma de suas reivindicações fundamentais.

Nesse contexto, a evolução histórica e normativa dos chamados direitos sexuais e reprodutivos, tanto no cenário internacional quanto no caso brasileiro, está diretamente relacionada às lutas feministas. Essa, dentre tantas outras pautas que avançaram no plano interno e internacional, demonstram que o movimento feminista e suas correntes têm sido um dos atores mais importantes na conquista por direitos fundamentais coletivos que transcendem o universo das mulheres e fazem avançar a efetivação do Estado democrático.

A tematização da perspectiva das mulheres, assim como de suas necessidades e de seus interesses, permitiu não só evidenciar os traços de uma política masculina (BIROLI, 2018), mas também politizar a política no período de transição democrática.

No campo dos direitos reprodutivos são as mulheres, os sujeitos mais afetados, e por isso protagonizam o papel de grupo vulnerável face um conjunto de elementos de opressão, discriminação e negação de direitos. A superação de um paradigma de opressão para um paradigma de vitimização foi assinalada por Pitch (1989) e possui pelos menos duas consequências diretas. A primeira é a indicação de que os conflitos que afetam as mulheres, em grande parte, estão relacionados com aspectos particulares da própria vida, sobre os quais se deseja atuar em primeira pessoa, sem delegação. A segunda é que a linguagem dos direitos humanos substitui a opressão pela discriminação.

Podemos compreender que o papel de vítima que a mulher passa a ocupar em diferentes contextos foi determinante para a atribuição de uma vulnerabilidade que se revela pela condição de ter sofrido ou de 
correr perigo de sofrer ofensas particulares, seja por parte de categorias de sujeitos individualizáveis, seja por parte do próprio Estado.

No campo dos direitos reprodutivos sobressai-se o poder de decisão relativo a todas as fases concernentes à reprodução humana, tendo como parâmetro a equidade das relações sociais, especialmente no tocante às relações de gênero. (VENTURA, 2009) Por mais que se trate, a princípio, de direitos pertinentes a todos os seres humanos, eles têm relevância específica para as mulheres devido ao seu papel no processo reprodutivo, evidenciando, neste aspecto, uma condição peculiar de vulnerabilidade.

Normalmente, os direitos reprodutivos estão coadunados, teórica e politicamente, com os direitos sexuais, que, por sua vez, versam sobre o livre exercício da sexualidade humana, independentemente de se concretizar o ato reprodutivo ou não. Sem a pretensão de se negar o caráter biológico da reprodução humana, os significados e interpretações conferidos aos processos sexuais e reprodutivos mostram-se como resultantes das interações sociais. (CAMPOS; OLIVEIRA, 2009)

Dentre os principais desafios à efetividade na implementação dos direitos reprodutivos desponta a questão da mortalidade materna que, como o nome já expressa, refere-se à morte de mulheres durante o período gestacional ou em até 42 dias após o parto e que apresentem como causa "qualquer fator relacionado ou agravado pela gravidez ou por medidas tomadas em relação a ela”. (BRASIL, 2002, p. 12) Ademais, tal taxa é um notável indicador do estado de saúde pública, não só das mulheres, mas de toda a população de determinada área, e indica o grau de reconhecimento dos direitos humanos das mulheres em certa sociedade.

Isso posto, no presente capítulo discutimos o caso Alyne Pimentel versus Brasil, analisado pelo Comitê referente à Convenção sobre a Eliminação de Todas as Formas de Discriminação Contra as Mulheres (CEDAW- sigla em inglês) da Organização das Nações Unidas (ONU). Tal caso adquiriu relevância por ter sido o primeiro no âmbito internacional a responsabilizar um Estado por uma morte materna.

Alyne, brasileira, negra e pobre, estava grávida de seis meses quando teve uma série de direitos reprodutivos desrespeitados, ao necessitar dos serviços públicos de assistência à saúde, no estado do Rio de Janeiro. Esses eventos resultaram em sua morte materna evitável de modo semelhante 
ao que acontece com centenas de outras mulheres todos os anos no Brasil e no mundo, em especial nos países em desenvolvimento.

Assim, propõe-se um estudo dos avanços normativos e efeitos práticos que podem ser percebidos a partir das recomendações produzidas pelo Comitê. Visa-se a compreensão das discrepâncias entre o cenário jurídico e a realidade social brasileira, sob uma ótica teórica feminista crítica aos direitos humanos. Tal análise possibilita o apontamento de uma série de obstáculos à efetivação dos direitos reprodutivos, tendo em vista a situação do nosso país.

\section{Críticas feministas aos direitos humanos}

As correntes feministas surgiram e se desenvolveram tendo como foco de análise as relações de gênero e o papel exercido pelas mulheres dentro da estrutura social. Durante o século XX, tais estudos foram responsáveis por destacar que na maior parte das ditas sociedades modernas, se não em todas, as mulheres possuíam, e ainda possuem, posições inferiores se comparadas às dos homens. Pode-se compreender que, como instrumento de análise, o pensamento feminista é capaz de apreender esferas sociais antes não incorporadas pelas teorias mainstream das ciências sociais e humanas, o que lhe confere uma natureza intrinsicamente política. (MIGUEL; BIROLI, 2014)

Atualmente, observa-se uma vasta pluralidade de vertentes nesse campo, o que pode tornar o termo feminismo um tanto genérico, mas ainda assim, sendo possível identificar inúmeras reflexões e transformações produzidas por esse movimento. Cabe assinalar que o ponto de congruência entre as diferentes concepções feministas reside no fato de ser uma ferramenta da análise crítica "sobre os mecanismos de opressão e produção da desigualdade social em decorrência do sexo/ gênero". (SANTOS, 2015, p. 295)

Como já mencionado, a linguagem dos direitos humanos faz com que o lugar e o papel da mulher como vítima coloque em evidência a superação da opressão: os oprimidos movem-se desta posição para ocupar a categoria das minorias vulneráveis. (PITCH, 2003) Contudo, isso se dá sem deixar de se ver mantida uma prática discriminatória a ser superada. 
Dentre os múltiplos domínios nos quais são desenvolvidas abordagens feministas, cabe aqui aprofundar as críticas elaboradas com relação ao sistema internacional de direitos humanos. Tendo como base o estudo de Edwards (2011), enunciam-se quatro principais críticas, quais sejam:a) a ausência das mulheres e de suas vozes; b) direitos humanos como direitos masculinos; c) dicotomia entre a esfera pública e a privada; e d) estereótipo feminino.

a) Ausência das mulheres e de suas vozes

Apontada como uma consequência da hegemonia masculina nas instituições e na vida pública em geral, constata-se a falta de representatividade feminina nos órgãos políticos e jurídicos de caráter decisório. Como efeito dessa situação, tem-se um sistema fundamentado nas experiências e perspectivas dos indivíduos do sexo masculino, no qual não se verifica haver capacidade empática de sopesar as condições dos variados sujeitos sociais. (EDWARDS, 2011)

Apesar de essa crítica ter perdido espaço à medida que as mulheres conquistaram posições em tais organizações, ela ainda se mostra válida devido a duas razões principais. Primeiro, destaca-se a questão da qualificação dos profissionais com relação à transversalidade de gênero, termo que engloba a inclusão da perspectiva de gênero na elaboração das políticas públicas em todos os níveis governamentais, e não só na criação de políticas específicas para se tratar a questão das mulheres. (BRIGAGÃO; RODRIGUES, 2011) Segundo, a despeito do aumento do número de mulheres nos setores públicos de poder, as demandas por elas trazidas ainda são apreciadas como questões de segundo plano. Arquiteta-se, assim, o chamado sidestream, que possui uma menor capacidade efetiva de implementação e recebe menos recursos se comparado aos conteúdos versados no mainstream. (EDWARDS, 2011)

b) Direitos humanos como direitos masculinos

Enfatiza-se que os direitos humanos são fundamentados, dentre várias matrizes teóricas que lhe explicam e compõem, naquilo que aflige e atemoriza os homens, pois a realidade vivida por esses sujeitos, que detinham o poder no momento da elaboração das normas, serviu, e serve 
ainda, como alicerce para o sistema. Observa-se que o padrão empregado na composição, aplicação e interpretação dos DH se relaciona com a vivência de mundo de uma determinada categoria social, e não da pluralidade dos seres humanos. (EDWARDS, 2011)

Infere-se que a linguagem utilizada é marcada por ideais incapazes de contemplar a diversidade social, paradoxalmente àquilo que é proposto em seu próprio discurso. Retrato disso é a priorização dos chamados direitos negativos, em detrimento dos direitos positivos, uma vez que, geralmente, são as classes oprimidas ou vulneráveis que demandam medidas afirmativas provindas dos Estados. (ÁVILA, 2014)

Logo, aos direitos civis e políticos é atribuída maior preponderância frente aos direitos econômicos, sociais e culturais. O problema aqui está no fato de que tais direitos particulares, em numerosos casos, podem ser lidos para justificar a manutenção do status quo existente, quando, por exemplo, vestem-se de liberdade religiosa para sustentar práticas tradicionais que afetam especialmente as mulheres, tal qual a mutilação genital. (UNICEF, 2016)

Edwards (2011) enfatiza a inabilidade do sistema de direitos humanos em perceber os aspectos fundantes de sua própria estrutura, razão pela qual a subordinação feminina é vista apenas como o resultado de falhas da edificação do sistema, em vez de um eixo basilar dessa construção. Finalmente, acentua-se que, para além das questões práticas cotidianas, esse ponto está relacionado aos desafios decorrentes das próprias relações sociais de poder inseridas na lógica patriarcal.

c) Dicotomia entre a esfera pública e a privada

Aborda-se aqui, o tratamento especial da esfera pública em detrimento da esfera privada percebido no contexto do direito internacional. Cabe esclarecer que o ambiente público é, tradicionalmente, considerado o espaço racional de desenvolvimento intelectual e cultural, onde os homens possuíam maior liberdade e poder de influência, enquanto o âmbito privado era tido como espaço natural e de reprodução, ao qual as mulheres pertenciam. (ARENDT, 2007) Como o foco do sistema internacional de DH está na ação do Estado para com os indivíduos, a esfera privada, 
constituída de relações entre os indivíduos, é, na maioria dos seus aspectos, ignorada, marginalizada ou silenciada. Cria-se, nesse sentido, uma hierarquia de opressões, na qual os danos cometidos dentro do meio privado são concebidos como menores quando contrapostos àqueles praticados pelas instituições face aos seus cidadãos. Banalizam-se, assim, as constantes violações empreendidas contra as mulheres e se contribui para a preservação do privado como um campo desregulamentado. Tal situação não é compreendida pelas críticas feministas como um mero acaso, mas sim como um exercício de escolha política. (EDWARDS, 2011)

d) Estereótipo Feminino

Nesse ponto, critica-se a produção de uma identidade coletiva apta a abarcar as diversas realidades das mulheres ao redor do globo. Afirma-se que tal estereótipo feminino, constituído pelas expectativas de proteção de mulheres ocidentais, brancas, heterossexuais, mães e esposas, como apontado por feministas não-ocidentais, não é capaz de representar as vivências dos variados grupos de mulheres. Além disso, ele continua a perpetuar uma ideia de dependência com relação aos homens, ao respaldar um imaginário das mulheres como vítimas, e não como atores de seus próprios destinos. (EDWARDS, 2011)

Dessa forma, deixa-se de considerar a interseccionalidade entre os diferentes fatores de discriminação que podem ser enfrentados pelo mesmo indivíduo, tal como gênero, classe econômica, etnia, nacionalidade, identidade de gênero, orientação sexual, entre outros. Tal conceito procura indicar as consequências, tanto estruturais, quanto dinâmicas, originadas da interação entre diferentes eixos da subordinação, os quais compõem aspectos do desempoderamento. (CRENSHAW, 2002)

Contudo, vale atentar para o fato de que tal identidade coletiva foi e ainda é usada pelo próprio ativismo feminista para substancializar as demandas das mulheres. Um exemplo ocorreu no Brasil durante o processo da Constituinte de 1988, quando se difundiu a ideia de uma identidade coletiva das mulheres brasileiras. (PITANGUY, 2011) Entende-se que o compartilhamento das opressões, por mais que essas possam assumir diferentes formas, é o fator de união das mulheres contra o sistema patriarcal. 


\section{Eliminar a discriminação como pauta de ação do CEDAW}

A partir da Declaração Universal dos Direitos Humanos (DUDH) de 1948, com o desenvolvimento do sistema internacional de proteção desses direitos, constatou-se a necessidade de construção de uma abordagem mais específica, voltada para determinados grupos sociais considerados vulneráveis ou marginalizados. (VENTURA, 2009) A criação de tratamentos especiais para atender às demandas dessas parcelas sociais visava garantir a efetividade de tais direitos para esse público, pois se percebeu a insuficiência do entendimento acerca da pluralidade humana. (NAÇÕES UNIDAS, 1995)

Dentre os grupos marginalizados destacam-se as mulheres, em razão das discriminações que sofriam e sofrem com base na própria cultura e na estrutura social dos Estados modernos. Cabe ressaltar que durante esse período, da segunda metade do século XX, as correntes feministas, tanto relacionadas ao ativismo político como à academia, conquistaram cada vez mais espaço. Foram responsáveis por estabelecer pautas dentro das agendas políticas nacionais e internacionais, ao mesmo tempo que promoveram mobilizações no âmbito da sociedade civil. (REDE FEMINISTA DE SAÚDE, 2008)

Como resultado desses movimentos se observou a edificação de mecanismos de proteção aos direitos das mulheres no âmbito internacional, processo que culminou na adoção da CEDAW, em 1979. Considerado o tratado internacional que versa de forma mais ampla e direcionada sobre tais direitos, ele inovou ao trazer de maneira explícita a definição do que se compreende por discriminação contra as mulheres. (NAÇÕES UNIDAS, 1979)

Constituído por preâmbulo e mais trinta artigos, a CEDAW consiste em um agrupamento de normas e princípios universais que devem ser utilizados como referência para as políticas internas dos Estados-parte na busca da erradicação de toda forma de discriminação contra as mulheres. (SANTOS, 2009)

Em seu preâmbulo, a CEDAW reafirma a importância dos direitos humanos fundamentais, a dignidade humana e a igualdade entre homens e 
mulheres como princípios a serem seguidos e respeitados. Ao longo de seus artigos, a Convenção abarca uma série de direitos sobre variados aspectos da vida em que as mulheres foram, historicamente, subordinadas e se compreende o papel do Estado como garantidor de tais direitos (artigo $2^{\mathrm{O}}, 3^{\mathrm{O}}, 4^{\mathrm{O}}$ e 24) através de ações afirmativas no combate à discriminação. (NAÇÕES UNIDAS, 1979)

Busca-se, deste modo, instaurar a igualdade entre homens e mulheres nas diferentes esferas da vida social. Isto significa dizer, na política (artigo $7^{\circ}$ e $8^{\circ}$ ), na economia (artigo 13), na educação (artigo $10^{\circ}$ ), no mercado de trabalho (artigo 11), na área jurídica (artigo 15), nas relações familiares (artigo 16), na saúde (artigo 12), entre outros. Além disso, versa-se sobre a representatividade das mulheres no contexto internacional (artigo $8^{\circ}$ ) e sobre suas garantias como cidadãs dos Estados nacionais (artigo $9^{\circ}$ ). Visa-se também à erradicação de situações ou condições degradantes, incompatíveis com o princípio da dignidade humana, cujos efeitos atingem sobremaneira as mulheres, como o tráfico de pessoas e a prostituição (artigo $5^{\circ}$ e $6^{\circ}$ ). (NAÇÕES UNIDAS, 1979)

O Comitê relacionado à Convenção foi implantado em 1982, como disposto no artigo 17, e trata-se de um organismo de defesa dos direitos das mulheres composto por 23 especialistas nessa área de atuação, que exercem mandatos com duração de quatro anos. Esses são eleitos pelos Estados-parte entre seus nacionais a título pessoal. Desde a sua implementação, a maior parte dos peritos nomeados para tal cargo foram, e continuam sendo, mulheres. (NAÇÕES UNIDAS, 1979)

O principal objetivo desse órgão refere-se ao acompanhamento do progresso da condição feminina nos países que ratificaram a Convenção. Para tanto, foi estabelecido como mecanismo de fiscalização a elaboração por parte dos Estados de relatórios sobre medidas legislativas, judiciárias e administrativas, que devem ser submetidos ao Comitê. Este, por sua vez, produzirá recomendações para auxiliar e monitorar medidas fundamentais à melhoria de vida das mulheres em tais nações. (NAÇÕES UNIDAS, 1979)

Por intermédio do Protocolo Facultativo, que entrou em vigor no fim do ano 2000, foram atribuídas ao Comitê competências adicionais frente 
aos países, as quais permitem as participações individuais ou de grupos de indivíduos. Para a apreciação dessas ações, todos os meios processuais da ordem interna dos Estados devem ter sido esgotados, salvo os casos em que os procedimentos internos ultrapassam prazos razoáveis ou que não conduzam a uma reparação efetiva. Também foram definidos os casos em que o Comitê rejeita as participações, quais sejam: se a mesma temática já tiver sido examinada anteriormente; se exibir incompatibilidade com a Convenção; se se considerar insuficientemente fundamentada; se consistir em abuso do direito; e se os fatos expressados na participação tiverem ocorrido antes da entrada em vigor do Protocolo. (NAÇÕES UNIDAS, 1999)

Vale ressaltar que o Comitênão possui status de tribunal jurisdicional, ou seja, os Estados escolhem ou não acatar suas recomendações, o que pode ser considerado um desafio para a efetivação dos direitos das mulheres. (MIRANDA, 2015) Entretanto, conforme o artigo $7^{\circ}$ do Protocolo, os Estados se obrigam a atribuir a devida importância às recomendações. Ademais, o cumprimento ou não das recomendações possui grande peso político no cenário internacional, sobretudo se o país apresentar uma retórica de defesa e garantia dos direitos humanos.

\section{Caso Alyne Pimentel}

O caso Alyne Pimentel v. Brasil foi emblemático para os direitos reprodutivos, pois pela a primeira vez um Estado foi responsabilizado pela ocorrência de uma morte materna evitável. O Comitê CEDAW não só verificou a existência de falhas na garantia desses direitos, como constatou que o problema está inserido em um quadro maior de violência estrutural. A seguir lê-se, resumidamente, a descrição dos eventos sucedidos, de acordo como o disposto na comunicação no 17/2008 do Comitê CEDAW. (UNITED NATIONS, 2011)

Alyne da Silva Pimentel Teixeira era uma mulher negra, de classe socioeconômica baixa, tinha 28 anos e residia no estado do Rio de Janeiro, em Belford Roxo. Mãe de uma menina de 5 anos, aqui denominada A., estava com 27 semanas de gestação, quando procurou assistência médica na Casa de Saúde Nossa Senhora da Glória, unidade mais próxima de sua 
casa, em 11 de novembro de 2002. Na ocasião, Alyne apresentava queixas como fortes dores abdominais e náuseas. Foi então atendida por um médico ginecologista, que receitou vitaminas e remédios para a realização do tratamento domiciliar, sem que nenhum exame laboratorial ou de ultrassonografia fosse realizado. Marcou-se retorno para feitura de exames de sangue e urina para dois dias depois.

No dia 13 de novembro, Alyne, acompanhada de sua mãe, retornou à unidade de saúde antes do horário marcado, pois seu quadro tinha se agravado. Ela foi atendida por um segundo médico, que, tendo em vista a situação da paciente, determinou sua internação. Ainda pela manhã do dia 13, foi feito o exame físico por um terceiro médico, que atestou a morte fetal. No entanto, passaram-se mais de quatorze horas até que o parto induzido acontecesse, às $19 \mathrm{~h} 55$.

O parto normal induzido não ocorreu de forma bem-sucedida, sendo necessária a posterior cirurgia de curetagem. Apesar da urgência do caso, tal procedimento cirúrgico só foi realizado na manhã do dia seguinte, 14 de novembro, e não trouxe melhoras ao quadro de Alyne. Ao contrário, ela passou a apresentar sintomas como vômito de sangue, baixa pressão arterial, desorientação, hemorragias, além de dificuldade de se alimentar. Embora o quadro estivesse cada vez mais crítico, sua família não a visitou no dia 14, pois a mãe de Alyne foi informada por telefone que a situação de sua filha se encontrava estável.

No dia 15 de novembro, com a permanência dos sintomas, passou-se à intervenção por meio de antibióticos e do auxílio na respiração, ao mesmo tempo que se reconheceu a incapacidade da Casa de Saúde de fornecer o tratamento adequado e imprescindível para a restauração da saúde de Alyne. Iniciou-se, assim, a procura por locais que possuíssem instalações apropriadas para o caso. O Hospital Geral de Nova Iguaçu era o único que satisfazia as necessidades estruturais e onde havia vagas disponíveis. Contudo, o Hospital se recusou a autorizar que sua única ambulância fizesse o transporte de Alyne no período vespertino daquele dia. Como sua família não tinha condições financeiras para arcar com os custos de um transporte particular, a paciente teve que esperar mais oito horas até que um carro da rede pública de saúde realizasse seu deslocamento. Nas duas últimas horas de espera, Alyne já apresentava sintomas de coma. 
Ao chegar no Hospital Geral, a paciente exibia um quadro clínico de hipotermia, alta dificuldade respiratória e coagulação intravascular disseminada. Sua pressão sanguínea chegou a zero e, em razão disso, a paciente precisou ser ressuscitada. Todos esses procedimentos de aferimento e intervenção foram realizados em uma maca colocada no corredor da sala de emergência, visto que não havia leitos disponíveis.

Consta na referida comunicação que os médicos responsáveis pelo tratamento de Alyne no Hospital Geral não tinham conhecimento de que ela havia estado grávida e que os sintomas apresentados resultavam de tal fato. Isso ocorreu porque, apesar da espera do transporte e de dois médicos da Casa de Saúde terem acompanhado a paciente até o Hospital, sua ficha médica não foi encaminhada para ele. Houve apenas um relato oral da condição da paciente por parte dos dois médicos que a acompanharam, no qual a notícia da gravidez foi omitida.

No dia 16 de novembro, ao visitar sua filha, a senhora Maria de Lourdes da Silva Pimentel a encontrou em estado crítico, pálida e com manchas de sangue na boca e nas roupas. Ainda sem ter posse dos dados prévios da paciente, o Hospital Geral solicitou à sua mãe que buscasse o alusivo prontuário na Casa de Saúde. Ao chegar lá, ainda pela manhã, Maria de Lourdes foi indagada sobre o interesse nos registros médicos de sua filha, os quais não foram entregues a ela antes do falecimento.

Alyne não resistiu e faleceu às 19 h do dia 16 de novembro de 2002. Em sua certidão de óbito constou como causa da morte hemorragia digestiva de acordo com o que foi apontado pela autópsia. Após sua morte, o Hospital Geral solicitou novamente à Maria de Lourdes que ela buscasse o prontuário médico de sua filha. Ao chegar na Casa de Saúde, Maria foi informada que o feto já estava morto há alguns dias e que essa foi, provavelmente, a causa da morte.

Em 11 de fevereiro de 2003, foi ajuizada uma ação perante o Tribunal de Justiça do Rio de Janeiro de danos morais e materiais por parte do viúvo e de sua filha, A., contra o estado (Ação Indenizatória n. 001525321.2003.8.19.0001). Por duas vezes pediu-se a tutela provisória da órfã, em virtude da circunstância. Entretanto, tais pedidos resultaram em um indeferimento e uma negação. Somente depois de decorridos 3 anos e 10 
meses do início do processo, o Poder Judiciário designou um médico para dar um parecer.

Passados quase 5 anos do ocorrido e sem uma resposta da justiça brasileira, a senhora Maria de Lourdes Pimentel, assessorada pelo Centro de Direitos Reprodutivos e pela Advocacia Cidadã pelos Direitos Humanos, encaminhou uma comunicação individual ao Comitê CEDAW contra o Estado brasileiro. Alegou-se a violação dos artigos $2^{\circ}$ e 12 da Convenção para Eliminação de todas as Formas de Discriminação contra a Mulher.

O primeiro trata da condenação por parte dos Estados de toda e qualquer atitude discriminatória que tenha por base o gênero. Os países se obrigam, através do referido artigo, a tomar medidas legislativas e outras para promover a igualdade entre homens e mulheres em seus territórios. Também é estabelecida a proteção jurídica dos direitos das mulheres. No que se refere ao artigo 12, ele versa sobre o direito de assistência à saúde das mulheres, que deve ser assegurado pelos Estados. Em seu parágrafo $2^{\mathrm{O}} \mathrm{o}$ artigo aborda, especificamente, a assistência apropriada à gestação, parto, puerpério e período de lactância. (NAÇÕES UNIDAS, 1979)

Em contrapartida, o Brasil alegou que o acontecimento não caracterizava discriminação contra as mulheres, mas era resultado da deficiência e baixa qualidade dos serviços de saúde prestados à população, em especial, pela Casa de Saúde Nossa Senhora da Glória, instituição privada conveniada ao SUS. (UNITED NATIONS, 2011)

O Comitê, após estudo do caso, recusou todas as alegações feitas pelo Estado brasileiro e considerou que esse violou as obrigações referentes ao artigo $1^{\circ}, 2^{\circ}$, alíneas 'c' e 'e', e 12 da Convenção. Também explicitou que a morte de Alyne Pimentel foi relacionada a complicações obstétricas diretas, ou seja, provocada pela gravidez e, como tal, deve ser analisada como morte materna. O Brasil se responsabilizou, dessa maneira, pelo não cumprimento do mínimo exigível de um Estado-parte, pois, ainda que se tenha tido acesso à assistência médica, ela foi de péssima qualidade e incapaz de garantir os direitos de Alyne. (SILVA, 2015)

Observou-se que o caso individual retrata a realidade de muitas mulheres brasileiras, principalmente daquelas situadas em posições sociais semelhantes à de Alyne. Portanto, tal caso aponta para um quadro 
de violência estrutural baseado não só na discriminação de gênero, mas também étnica, socioeconômica, cultural, entre outros. Alertou-se para como tais variáveis determinam a condição de saúde de grupos que estão na intersecção de múltiplos fatores de discriminação. (SILVA, 2015)

Finalmente, o Comitê formulou recomendações tanto em caráter individual, com o objetivo de reparar os danos sofridos pelos parentes da vítima, como em caráter geral, para que o país adotasse medidas com a finalidade de diminuir, ou mesmo erradicar casos como o de Alyne. Relativo às reparações individuais para a família, destacou-se que a mãe e a filha da vítima deveriam receber uma devida compensação financeira, proporcional à gravidade das violações. (UNITED NATIONS, 2011)

No que concerne às recomendações de caráter geral, reitera-se a obrigação do Estado brasileiro de garantir o direito à maternidade segura através de um sistema de saúde acessível a todas as mulheres. Para tanto, ressalta-se a necessidade de formação adequada para os profissionais da saúde, fornecimento de recursos, tais como remédios eficazes, fiscalização do funcionamento das unidades de saúde, além da segurança jurídica, que deve ser ofertada às mulheres que sofrerem violações de direitos. Essas medidas expressam o objetivo final de reduzir as taxas de mortalidade materna evitável. (UNITED NATIONS, 2011)

\section{Repercussões do caso para os direitos reprodutivos no Brasil: avanços normativos e efeitos práticos}

O caso Alyne Pimentel v. Brasil possui grande relevância para o campo dos direitos das mulheres, particularmente para os direitos reprodutivos, por ter sido a primeira vez que um Estado foi responsabilizado em um órgão internacional por uma morte materna. Além disso, foram identificadas e exploradas as lacunas discriminatórias no sistema de saúde brasileiro pela perspectiva de um sujeito pertencente a uma minoria. (COOK, 2013)

De tal forma criam-se precedentes jurídicos capazes de impactar futuras decisões sobre o tema dos direitos das mulheres, tanto no nível internacional quanto em relação à ordem jurídica interna dos Estados. Ademais, pode-se ter em vista o avanço relacionado ao reforço na inserção 
dos direitos reprodutivos dentro do domínio dos direitos humanos, o que contribui para um tipo de intervenção dinâmica que possua capacidade de materialização por intermédio de mecanismos e ações efetivas. (VENTURA, 2009)

Vale salientar que, em matéria de direito, o Comitê CEDAW consignou que o Estado brasileiro falhou no monitoramento das instituições privadas de saúde quando essas oferecem serviços terceirizados para o SUS; no atendimento de saúde específico e distinto necessitado por Alyne durante sua gravidez; em dar especial enfoque para as mulheres afrodescendentes e de origem socioeconômica baixa; e no cumprimento de suas obrigações de assegurar a proteção efetiva e o acesso à justiça. (UNITED NATIONS, 2011)

Quanto aos avanços normativos, Cook (2013) apresenta quatro importantes aspectos, dispostos a seguir.

Primeiramente, tem-se o entendimento da mortalidade materna evitável como uma questão de direitos humanos. São reconhecidas as necessidades próprias das gestantes, que demandam atenção especial do Estado, o qual, por sua vez, deve cumprir com suas obrigações frente a essa demanda social. Estabelecem-se, assim, bases para a transformação do pensamento, ainda muito disseminado no senso comum, referente à explicação das mortes maternas como algo relacionado ao propósito divino ou ao destino. Passa-se, então, a encarar tal problemática como uma injustiça social incompatível com o compromisso assumido pelas nações na defesa dos direitos humanos.

O segundo ponto abordado se refere à avaliação da mortalidade materna como uma variedade de marginalização produzida com base no gênero, de modo a também ampliar a jurisprudência internacional com relação ao direito à saúde. Assim,

ao sustentar que a falha em oferecer cuidados essenciais à saúde, que somente as mulheres necessitam, é uma forma de discriminação contra as mulheres que os governos estão obrigados a remediar, o Comitê legitima as demandas das mulheres grávidas. (COOK, 2013, p. 7) 
Ressalta-se que somente os indivíduos do sexo feminino manifestam a capacidade fisiológica de gerar um novo ser humano. Destarte, carecese de medidas específicas na assistência à saúde para que as mulheres tenham garantida sua segurança ao longo dos processos de gravidez, parto e puerpério. Tais ações não assumem um caráter discriminatório, mas são meio de se promover a igualdade, posto que os diversificados grupos sociais possuem diferentes requisições e não podem ser tratados de maneira uniforme pelo Estado.

Em terceiro lugar, tal caso promoveu avanços normativos, ao passo que atestou a discriminação interseccional sofrida por Alyne, que havia encontrado um maior grau de dificuldade no acesso aos serviços de saúde se comparado à situação que uma mulher grávida de classe social dominante teria enfrentado. De fato, a experiência discriminatória vivenciada por Alyne teve suas raízes em múltiplos fatores como gênero, etnia e classe socioeconômica. Portanto, todas essas variáveis devem ser consideradas na análise do caso, já que tiveram efeito único e específico, que não é comum ao conjunto de mulheres grávidas brasileiras, mas corresponde a um determinado setor social.

Finalmente, apesar de se tratar de um caso individual, o Comitê apontou as falhas sistêmicas e institucionais na assistência à saúde, as quais foram responsáveis por causar a morte de Alyne. Evidenciou-se que tais lacunas ocorrem quando se analisa as parcelas sociais mais vulneráveis, ou seja, aquelas em que é possível identificar maior incidência de coeficientes interseccionais. Portanto, trata-se de uma problemática sistêmica, a qual deve ser abordada em sua totalidade para uma efetiva melhoria das condições de saúde das mulheres.

Quanto aos efeitos práticos, em virtude do desenvolvimento do caso na CEDAW e das recomendações geradas, o governo brasileiro emitiu, em agosto de 2014, um relatório relativo às reparações e às políticas públicas impulsionadas por esse processo, o qual é apresentado a seguir.

No que diz respeito às reparações individuais referentes à família, a senhora Maria de Lourdes da Silva Pimentel, mãe de Alyne, foi indenizada pela União através da Secretaria de Direitos Humanos da Presidência da República via ordem bancária n 2014OB800721. (BRASIL, 2014) Maria 
de Lourdes também participou de evento para o reconhecimento público da morte de sua filha na cidade de Brasília, em 25 de março de 2014.

Já a reparação financeira concedida à filha de Alyne, A., está seguindo os trâmites judiciais de acordo com o Parecer no 073-F/13-AC/DPI/ PGU da Procuradoria Geral da União - Departamento Internacional, em atendimento à decisão proferida pela Dra. Juíza Gisele Guida de Faria, ao Processo: 0015253-21.2003.8.19.0001. Atualmente, o processo encontrase em análise de recurso pelo Supremo Tribunal Federal e pelo Superior Tribunal de Justiça, de forma que, mesmo passados 15 anos do início do litígio na justiça brasileira, A. ainda não foi indenizada pelos danos sofridos.

Ademais, foram concretizadas reparações simbólicas. A Unidade de Terapia Intensiva para Adultos da Maternidade Mariana Bulhões, localizada em Nova Iguaçu, recebeu o nome de "Alyne Pimentel”, onde foi colocada a placa com os seguintes dizeres: "reparação simbólica e reconhecimento da sua morte evitável, pela melhoria da qualidade do atendimento à saúde das mulheres". (BRASIL, 2014, p.3) Também no Rio de Janeiro, no espaço de convivência das gestantes da Maternidade Mãe Mesquita, foi prestada homenagem a Alyne através da seguinte epígrafe:

\footnotetext{
À Alyne Pimentel, sua mãe e sua filha - Aqui onde colaboramos com a natureza no trazer à vida damos o seu nome a este espaço, como reparação simbólica do Estado brasileiro e como nosso compromisso na redução da morte materna e qualidade no atendimento. (BRASIL, 2014, p. 3)
}

No que tange às políticas públicas, o relatório enfatiza a manutenção de diversas medidas já existentes à época do parecer, as quais buscam por diferentes meios a redução da mortalidade materna e a melhoria na qualidade de assistência à saúde para as mulheres. Dentre essas estão a Política Nacional de Atenção Integral à Saúde da Mulher (2004); o Pacto Nacional pela Mortalidade Materna (2004); a Política Nacional de Direitos Sexuais e Reprodutivos (2005); o Plano de Qualificação das Maternidades e Redes Perinatais da Amazônia Legal e do Nordeste (2009). Também é enfatizada a implantação da Rede Cegonha (2011) como uma estratégia "para acelerar a qualificação da atenção obstétrica e das redes perinatais” (BRASIL, 
2014, p. 4). Considera-se tal política um meio para a sistematização e institucionalização do modelo de acompanhamento e parto humanizado.

Para além das ações já citadas, o relatório ressalta alguns mecanismos que incluem a participação da sociedade civil para o controle e o acompanhamento das taxas de mortalidade materna, como o Fórum Perinatal e o Painel de Monitoramento da Mortalidade Materna.

Desse modo,

o relatório se propõe a demonstrar que o Governo Brasileiro implantou, implementou e aperfeiçoou todas as medidas para atender às recomendações do Comitê CEDAW no caso Alyne da Silva Pimentel, melhorando a saúde da mulher e da criança em todo território nacional. (BRASIL, 2014, p.3)

Entretanto, o cenário desenhado em tal documento não parece condizer com a realidade enfrentada por diversas mulheres brasileiras. Nesse sentido, são analisados, abaixo, os dados referentes à taxa de mortalidade materna no Brasil entre os anos de 2011 e 2016, ${ }^{1}$ período entre o parecer do Comitê CEDAW e os dados mais recentes disponíveis.

Tabela 1 - Óbitos maternos no Brasil: 2011-2016

\begin{tabular}{c|c} 
Ano & Óbitos maternos \\
\hline 2011 & 1.610 \\
2012 & 1.583 \\
2013 & 1.686 \\
2014 & 1.739 \\
2015 & 1.738 \\
$2016 *$ & 1.618 \\
\hline
\end{tabular}

Fonte: MS/SVS/CGIAE - Sistema de Informações sobre Mortalidade - $\mathrm{SIM}^{2}$

*Situação da base nacional em 19/09/2017.

1 Os dados foram obtidos no DATASUS. Os números equivalentes a 2016 são preliminares.

2 Disponível em: <http://tabnet.datasus.gov.br/cgi/tabcgi.exe?sim/cnv/mat1ouf.def>. Acesso em:31 jan 2018. 
Observa-se, com base nesses dados, que os números de mortalidade materna no Brasil não apresentaram diminuições significativas, com

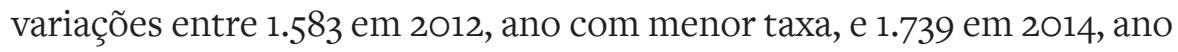
com o maior índice. Constata-se, ainda, que os dados preliminares relativos a 2016 indicam maior mortalidade do que o ano de 2011, quando foram feitas as recomendações por parte do Comitê CEDAW. Frisa-se que o Brasil não atingiu a Meta do Milênio para redução de mortes maternas fixada pela ONU até o ano de 2015, quadro que é agravado se considerado que $92 \%$ das mortes são classificadas como evitáveis e 60\% das vítimas são negras ou pardas. (BRASIL, 2015)

Dez anos após o ocorrido com Alyne, a Plataforma de Direitos Humanos econômicos, sociais, culturais e ambientais (DHESCA Brasil) realizou uma missão para verificar a situação das maternidades da Baixada Fluminense. De acordo com o relatório, a conjuntura encontrada assemelha-se bastante às condições de 2002. (DHESCA, 2013) A Casa de Saúde Nossa Senhora da Glória continua sem banco de sangue próprio, unidade de terapia intensiva adequada e sistema de transporte eficiente. Já na maternidade do Hospital Geral de Nova Iguaçu, a condição detectada era ainda mais precária: havia carência de profissionais de saúde, "as paredes das enfermarias e salas de parto estavam cobertas de mofo e infiltrações, as portas destruídas, os corredores com o piso corroído”. (DHESCA, 2013, p. 78)

Logo, percebe-se um descompasso entre o relatório brasileiro apresentado em resposta ao Comitê CEDAW e o quadro real alusivo aos direitos reprodutivos das mulheres, sobretudo no tocante à mortalidade materna. A DHESCA Brasil apontou em seu relatório uma grande quantidade de barreiras que prejudicam o progresso nessa área da saúde pública, dentre as quais se pode citar

[...] a descontinuidade das ações de vigilância e do monitoramento dos eventos e agravos; o baixo grau de implementação de comitês de mortalidade materna; o baixo grau de interiorização das políticas de saúde voltadas especificamente para este problema e o desconhecimento dos gestores locais sobre as políticas de saúde que visam a redução da mortalidade materna. [...] a fragilidade dos mecanismos de monitoramento da implementação das políti- 
cas; o desequilíbrio entre os esforços do Governo Federal em implementar as ações; a ausência de interesse e vontade política em alguns estados e municípios para se alcançar as populações mais vulneráveis a estes agravos; a não incorporação do Pacto Nacional de Redução da Mortalidade Materna e Neonatal à agenda de compromissos dos governos locais; a pouca disseminação e conhecimento das normas técnicas produzidas pelo nível central de gestão e a insuficiência de insumos, equipamentos e medicamentos. (DHESCA, 2013, p. 78)

A partir dessa análise, infere-se uma série de fronteiras políticas para a efetivação de determinados direitos, principalmente quando eles dependem da aplicação de políticas públicas, demonstrando a discrepância existente entre a legalidade e sua aplicação social. Alerta-se, assim, para a "postura dominante da vertente normativa, cuja aposta na criação de regras e leis parece ser o suficiente para constituir cidadania”. (PRÁ; EPPING, 2012, p. 43)

Dessa maneira, verifica-se, por exemplo, a necessidade de se pensar como as definições relacionadas à questão de gênero são interpretadas pelos profissionais da saúde, responsáveis pela aplicação prática de tais medidas. Exige-se a criação de mecanismos através dos quais “as nomeações não fiquem somente na escrita e na elaboração da política e possam nos ajudar, de fato, a ir transformando o cotidiano dos serviços de saúde". (BRIGAGÃO; RODRIGUES, 2011, p. 58)

Soma-se a isso, no caso brasileiro, a questão da violência e do racismo institucional praticados contra as gestantes pelo próprio quadro médico. Tal condição pode ser expressa de diferentes formas e varia da discriminação e violência verbal até a violência física, na qual se incluem a não-utilização de medicamentos anestésicos, abuso sexual e negligência médica. (AGUIAR; D’OLIVEIRA, 2010) Ademais, é imperativo ponderar a respeito da diversidade de sujeitos e contextos atingidos por essas políticas, tendo em vista que o sucesso ou fracasso delas está justamente relacionado à melhor abordagem e implantação em determinada conjuntura social e regional. (RODRIGUES, 2011)

Isto posto, vale a reflexão acerca da assimilação da perspectiva de gênero no debate político para o estabelecimento de avanços, não só no que 
diz respeito às taxas de mortalidade materna, mas na construção de uma sociedade menos desigual. Reconhece-se a interdisciplinaridade desse campo, que propõe a "integração de dimensões institucionais, simbólicas e subjetivas” (PRÁ; EPPING, 2012, p. 42) para que se possa firmar a igualdade entre homens e mulheres.

\section{Considerações finais}

A análise dos efeitos do caso Alyne Pimentel v. Brasil quanto à consolidação dos direitos reprodutivos permite refletir sobre a linguagem dos direitos humanos na arena internacional e sua implicação para as mulheres, como também oferece um indicativo do impacto de uma recomendação internacional para a efetividade de políticas públicas atentas às condições de gênero e vulnerabilidade.

Os direitos reprodutivos se referem ao livre poder de escolha frente ao processo reprodutivo. Ou seja, trata-se da capacidade jurídica conferida aos indivíduos de ter autonomia sobre seus próprios corpos, sexualidade e reprodução, além de possuírem as condições e informações necessárias para tal decisão. Nesse sentido, é esperado que os Estados assumam um papel de não-coerção e não-intervenção nos corpos de seus cidadãos e cidadãs, bem como devem adotar medidas positivas que visem a garantia de tal liberdade.

O surgimento e a evolução dos direitos sexuais e reprodutivos estiveram diretamente relacionados aos movimentos e às teorias feministas desenvolvidos durante o século XX. Esses apresentavam, e ainda apresentam, a autonomia corporal como uma demanda fundamental para se alcançar a construção de uma sociedade baseada na igualdade e equidade de gênero. Tal afirmação pode ser confirmada tanto para o cenário internacional quanto para o contexto brasileiro, já que os movimentos de mulheres no Brasil foram e têm sido de enorme relevância para a conformação dos avanços normativos relativos à questão.

Nesse quadro, a mortalidade materna é um dos maiores desafios para a efetiva implementação dos direitos reprodutivos, sobretudo nos países em desenvolvimento. A definição de morte materna descreve os óbitos 
causados direta ou indiretamente durante os períodos de gestação, parto e puerpério. É um indicador sensível às condições de saúde de uma população e do reconhecimento dos direitos das mulheres em determinada sociedade.

Por este motivo, a redução dos índices de morte materna é uma das metas do Milênio das Organizações das Nações Unidas.

Ao caso Alyne Pimentel v. Brasil, que teve espaço no Comitê da CEDAW, atribui-se enorme valor, pois se tratou do primeiro caso em um órgão internacional a reconhecer a responsabilidade estatal face à mortalidade materna. Mulher, negra e de classe econômica desfavorecida, Alyne teve diversos direitos desrespeitados quando precisou dos serviços públicos de assistência à saúde aos seis meses de gestação. Sua morte exemplifica não só a displicência dos serviços públicos de saúde em relação às especificações relacionadas aos direitos reprodutivos, como também se torna um nefasto exemplo da discriminação e do desrespeito em relação às mulheres, derivado da violência estrutural que se reproduz na sociedade brasileira.

A partir da análise do caso, percebe-se um conjunto de avanços normativos que abrem precedentes quanto ao desenvolvimento e aplicação dos direitos das mulheres, nacional e internacionalmente, tendo sido o maior deles o próprio reconhecimento da obrigação dos Estados de garantir os recursos necessários aos indivíduos no decurso do processo reprodutivo.

Assim, o parecer e as recomendações produzidas pelo Comitê da CEDAW apresentam o destacado propósito de contribuir para a consolidação dos direitos das mulheres, particularmente, com relação ao caso analisado, dos direitos reprodutivos. Cabe lembrar que tais proposições não buscaram apenas reparar as perdas individuais geradas à família de Alyne, mas promover o aperfeiçoamento da situação geral de assistência à saúde das mulheres no Brasil, bem como elencar fatores de discriminação de gênero que o Estado, ao ratificar a referida Convenção, tem por obrigação combater.

Verifica-se a existência de várias políticas públicas e programas que visam a diminuição dos índices de mortalidade materna, a maioria dos 
quais já vinha sendo desenvolvido antes do posicionamento do referido Comitê. Considera-se, então, a importância do caso como um meio de alcance da atenção governamental e social para essa problemática, que continua atingindo centenas de mulheres por ano em nosso país.

Constata-se uma grande discrepância entre o panorama jurídico e a realidade prática social vivenciada pelas mulheres brasileiras. Exemplo disso é que, apesar de todas as medidas declaradas pelos poderes brasileiros, não foram observadas diminuições significativas no número de mortes maternas ao longo do período desde o parecer, em 2011, até o ano de 2016.

Tendo como base as críticas feministas aos direitos humanos, são apontados alguns possíveis fatores que podem ser levados em consideração para se compreender os desafios quanto à efetividade dos direitos reprodutivos no Brasil. Dentre eles se pode realçar as fronteiras na implantação das políticas de saúde pública, como a dificuldade de comunicação e interpretação dos conteúdos e definições propostos por tais políticas pelo quadro profissional responsável, isto é, médicos e enfermeiros, por exemplo. Ressalta-se, ademais, a falta de vontade política dos gestores, a ausência de uma rede integrada de saúde entre os diferentes níveis governamentais e a própria mentalidade associada ao senso comum de naturalização das mortes causadas pela gravidez.

Salienta-se, ainda, um quadro de violência obstétrica e racismo institucionalizados, no qual as mulheres que mais necessitam de assistência e suporte são muitas vezes menosprezadas por suas condições sociais e não recebem o tratamento adequado. Fala-se, aqui, da interseccionalidade, conceito que abarca a conjunção de fatores discriminatórios em um único caso, assim como foi visto no ocorrido com Alyne.

Nesse sentido, entende-se a relevância de dar visibilidade para o caso aqui exposto como uma ferramenta de informação e debate, que se reúne a outros tantos movimentos e ações feministas, individuais e coletivas, voltados para construir uma realidade na qual, de fato, não haja discriminação de gênero e que as mulheres alcancem a autonomia sobre seus corpos. 


\section{Referências}

ABREU, M.A. (Org.). Redistribuição, reconhecimento e representação: diálogos sobre igualdade de gênero. Brasília: Ipea, 2011. AGUIAR, J. M. de; D’OLIVEIRA, A. F. P. L. Violência institucional em maternidades públicas sob a ótica das usuárias. Interface: Comunicação, Saúde, Educação, Botucatu, v. 15, n. 36, p. 79-91, ago. 10. Disponível em: <http://www.scielo.br/pdf/icse/2010nahead/aop4010>. Acesso em: 12 fev. 2018.

ARENDT, Ha.. A condição humana. 10. ed. Rio de Janeiro: Forense Universitária, 2007. Disponível em: <https://archive.org/stream/ ARENDTHannah.ACondioHumana./ARENDT, Hannah. A condição humana.\#page/n1/mode/2up/search/esfera+privada>. Acesso em: 15 fev. 2018.

ÁVILA, F. de. Direito e direitos humanos. Curitiba: Appris, 2014. ÁVILA, M. B. os direitos sexuais devem ser uma pauta constante do feminismo. Jornal da Rede de Saúde, Florianópolis, n. 24, p. 11-17, dez. 2001. Disponível em: <http://www.redesaude.org.br/home/ conteudo/biblioteca/biblioteca/jornal/oo8.pdf>. Acesso em: 18 jan. 2018.

BIROLI, F. De onde surgiram essas mulheres? Le Monde Diplomatique Brasil, São Paulo, Ano 11, n. 126, jan. 2018.

BRASIL. Comitê para Eliminação da Discriminação contra a Mulher. Caso Alyne da Silva Pimentel. Relatório do governo brasileiro/agosto 2014. Brasília, 2014. 47 p. Disponível em: <http://www.spm.gov.br/ assuntos/acoes-internacionais/Articulacao/articulacao-internacional/ onu-1/Rela>. Acesso em: 10 jan. 2018.

BRASIL. Senado Federal. Brasil não cumpre metas do milênio para redução de mortes maternas. Senado Notícias, 2015. Disponível em: <https://www12.senado.leg.br/noticias/materias/2015/07/o1/brasil-naocumpre-metas-do-milenio-para-reducao-de-mortes-maternas $>$. Acesso em: 16 fev. 2018.

BRASIL. Departamento de Informática do SUS. Óbitos de mulheres em idade fértil é óbitos maternos - Brasil. Disponível em: <http://tabnet. datasus.gov.br/cgi/tabcgi.exe?sim/cnv/matıouf.def>. Acesso em: 31 jan. 2018. 
BRASIL. Ministério da Saúde. Secretaria de Políticas da Saúde. Manual dos Comitês de Mortalidade Materna. 2. ed. Brasília: Ministério da Saúde, 2002. Disponível em: $<$ http://bvsms.saude.gov.br/bvs/publicacoes/ cdo7_13.pdf $>$. Acesso em: 16 fev. 2018.

BRIGAGÃO, J.; RODRIGUES, M. T. A mulher como sujeito: direitos sexuais, reprodutivos e políticas na área da saúde. In: ABREU, M.

A. Redistribuição, reconhecimento e representação: diálogos sobre igualdade de gênero. Brasília: Ipea, 2011.

CAMPOS, C. H. de; OLIVEIRA, G.C. de (Org.). Saúde reprodutiva das mulheres: direitos, políticas públicas e desafios. Brasília: Cfemea, 2009. Disponível em: <http://www.cfemea.org.br/images/stories/publicacoes/ colecao2oanos_saudereprodutivadasmulheres.pdf $>$. Acesso em: $16 \mathrm{fev}$. 2018.

COOK, R. J. Human Rights and Maternal Health: Exploring the Effectiveness of the Alyne Decision. Journal OfLaw, Medicine \& Ethics, Toronto, v. 41, n. 1, p.103-123, Mar. 2013. Tradução de Maria Elvira Vieira de Mello e Beatriz Galli. Available on: <https://www.law.utoronto.ca/ utfl_file/count/documents/reprohealth/Pub-AlynePortuguese.pdf $>$. Access on: 10 fev. 2018.

CRENSHAW, K. Documento para o encontro de especialistas em aspectos da discriminação racial relativos ao gênero. Revista Estudos Feministas, Florianópolis, v. 10, n. 1, p. 171-188, 2002. Disponível em: $<$ http://www.scielo.br/pdf/ref/v1on1/11636.pdf>. Acesso em: o9 set. 2017. DHESCA (Org.). Relatório sobre mortalidade materna no contexto do processo de implementação da decisão do Comitê CEDAW contra o Estado brasileiro no caso Alyne da Silva Pimentel: missão às unidades de saúde nos municípios da Baixada Fluminense no estado do Rio de Janeiro. Curitiba: Dhesca, 2013. Disponível em: <http://unfpa.org.br/Arquivos/Relatorio_ caso_alyne_pimentel.pdf >.Acesso em: 15 jan. 2018.

DINIZ, D. Estado laico, objeção de consciência e políticas de saúde. Caderno de Saúde Pública, Rio de Janeiro, v. 9, n. 29, p. 1704-1706, set. 2013. Disponível em: <http://www.scielo.br/pdf/csp/v29n9/ao2v29n9. pdf $>$. Acesso em: 16 fev. 2018.

EDWARDS, A. Violence Against Women Under International Human Rights Law. Cambrigde: Cambridge University Press, 2011. 
EMMERICK, R. Corpo e poder: um olhar sobre o aborto à luz dos direitos humanos e da democracia. 2007. 199 f. Dissertação (Mestrado) -

Pontifícia Universidade Católica do Rio de Janeiro, Rio de Janeiro, 2007. Disponível em: <https://www.maxwell.vrac.puc-rio.br/10063/10063_4. PDF $>$. Acesso em: 03 fev. 2018.

MIGUEL, L. F.; BIROLI, F. Feminismo e política. São Paulo: Boitempo, 2015 .

MIRANDA, M. A. P. de. Alyne Pimentel versus Brasil e o princípio do acesso à justiça: um estudo de caso. 2015. 20 f. Monografia (Especialização) - Escola da Magistratura do Estado do Rio de Janeiro, Rio de Janeiro, 2015. Disponível em: <http://www.emerj.tjrj.jus.br/paginas/trabalhos_ conclusao/1semestre2015/pdf/MarianaAlmeidaPicancodeMi $>$. Acesso em: 20 jan. 2018.

NAÇÕES UNIDAS. Convention on the Elimination of All Forms of Discrimination against Women. 1979. Disponível em: <http://www.un.org/ womenwatch/daw/cedaw/text/econvention.htm >. Acesso em: 30 nov. 2017 .

NAÇÕES UNIDAS. Declaração e Plataforma de Ação da IV Conferência Mundial Sobre a Mulher. 1995. Disponível em: <http://www.unfpa.org.br/ Arquivos/declaracao_beijing.pdf $>$. Acesso em: 31 jan. 2018.

NAÇÕES UNIDAS. Protocolo Opcional à Convenção sobre a Eliminação de Todas as Formas de Discriminação contra as Mulheres. 1999. Disponível em: $<$ http://pfdc.pgr.mpf.mp.br/atuacao-e-conteudos-de apoio/legislacao/ mulher/prot_formas_discriminacao.pdf >. Acesso em: 12 fev. 2018.

NAÇÕES UNIDAS. Relatório da Conferência Internacional sobre População e Desenvolvimento: Plataforma do Cairo. 1994. Disponível em: <http:// www.unfpa.org.br/Arquivos/relatorio-cairo.pdf $>$. Acesso em:31 jan. 2018. PITANGUY, J. Mulheres, constituinte e constituição. In: ABREU, M. A. (Org.). Redistribuição, reconhecimento e representação: diálogos sobre igualdade de gênero. Brasília: Ipea, 2011.

PITCH, T. Um Derecho para Dos. La construcción jurídica de género, sexo y sexualidad. Madrid: Editorial Trotta, 2003.

PRÁ, J. R.; EPPING, L. Cidadania e feminismo no reconhecimento dos direitos humanos das mulheres. Revista Estudos Feministas, Florianópolis, 
v. 20, n. 1, p. 33-51, abr. 2012. Disponível em: < http://dx.doi.org/10.1590/ s0104-026x2012000100003>. Acesso em: 12 jan. 2018.

REDE FEMINISTA DE SAÚDE. Marcos da saúde das mulheres, dos direitos reprodutivos e direitos sexuais: ferramenta para a ação política das mulheres. 2008. Disponível em: $<$ https://edisciplinas.usp.br/pluginfile. php/169650/mod_resource/content/2/Texto DDSSDDRR.pdf>.Acesso em: 21 jan. 2018.

RIO DE JANEIRO. Tribunal de Justiça. Processo n ${ }^{0}$ : 001525321.2003.8.19.0001. Disponível em: <http://www4.tjrj.jus.br/ejud/ ConsultaProcesso.aspx?N=2015.227.00730\&USER=>. Acesso em: $17 \mathrm{fev}$. 2018.

SANTOS, M. F. Teorias feministas do direito: contribuições a uma visão crítica do direito. In: CONPEDI (Org.). Filosofia do Direito I. Florianópolis: Conpedi, 2015. p. 294-310. Disponível em: <http://www. indexlaw.org/index.php/filosofiadireito/article/view/954/949>. Acesso em: 05 fev. 2018.

SILVA, A. M. Caso Alyne Pimentel: análise do direito humano à saúde e a morte materna. 2015. 63 f. TCC (Graduação) - Centro Universitário de Brasília, Brasília, 2015. Disponível em: <http://www.repositorio.uniceub. br/bitstream/235/7097/1/21079230.pdf>. Acesso em: 14jan. 2018.

SOUZA, M. C. de. A convenção sobre a eliminação de todas as formas de discriminação contra as mulheres e suas implicações. Revista Eletrônica de Direito Internacional, Belo Horizonte, v. 5, p. 346-386, 2009. Disponível em: <http://centrodireitointernacional.com.br/static/revistaeletronica/ volume5/arquivos_pdf/sumario/merci>. Acesso em: 20 jan. 2018.

TICKNER, J. A. What is your research program? Some feminist answers to International Relations methodological questions. International Studies Quarterly, v. 49, n. 1, p. 1-22, fev. 2005.

UNICEF. Female Genital Mutilation/Cutting: A Global Concern. 2016. Disponível em: <https://www.unicef.org/media/files/FGMC_2016_ brochure_final_UNICEF_SPREAD.pdf $>$. Acesso em: $17 \mathrm{fev} .2018$.

UNITED NATIONS. Committee on the Elimination of Discrimination Against Women. Communication n ${ }^{0}$ 17/2008. 2011. Available on: 
em: <http://www2.ohchr.org/english/law/docs/CEDAW-C-49-D-17-2008. pdf $>$. Access on: 20 Dec. 2017.

VENTURA, M. Direitos reprodutivos no Brasil.3. ed. Brasília: UNFPA, 2009.

ZANATTA, L. F. et al. Igualdade de gênero: por que o Brasil vive retrocessos? Caderno de Saúde Pública, Rio de Janeiro, v. 8, n. 32, p. 1-4, ago. 2016. Disponível em: <http://www.scielo.br/pdf/csp/v32n8/16784464-csp-32-08-eooo89616.pdf>. Acesso em: 16 fev. 2018. 


\section{SISTEMAS ELEITORAIS}

E PRESENÇA DAS

MULHERES NA

REPRESENTAÇÃO

POLÍTICA:

apontamentos de uma perspectiva comparada entre Brasil, Finlândia e Áustria

Maria Aparecida Azevedo Abreu 


\section{Introdução}

As desigualdades sociais entre homens e mulheres se apresentam muitas vezes de forma injusta e constituem um problema em todos os países do mundo em maior ou menor intensidade, com matizes variados. O Fórum Econômico Mundial - World Economic Forum - elabora e divulga anualmente, desde 2006, o Relatório Global de Desigualdade de Gênero - Global Gender Gap Report -, em que a desigualdade de gênero é medida de acordo com um índice que varia de o (zero) a 1 (um), ou de o (zero) a 100 (cem por cento), em que o o (zero) seria a absoluta desigualdade, e o $100 \%$, ou 1 (um), seria a absoluta igualdade. O índice é composto de 4 dimensões: (i) Participação econômica e oportunidades; (ii) Educação; (iii) Saúde e Mortalidade; (iv) Ocupação de cargos e de poder político. Em nenhum país o índice 1 é atingido. O país que, há vários anos, está mais perto da igualdade, é a Islândia, que recentemente aprovou uma lei em que empresas devem mostrar em seus planos de cargos e salários que praticam a equidade salarial entre homens e mulheres. Mesmo naquele país, conhecido por suas greves de mulheres, não se pode dizer que homens e mulheres são socialmente iguais.

Na última edição publicada desse relatório, em 2017, o Brasil ocupava a $79^{a}$ posição, com o índice global de o,687. Nas dimensões de educação e saúde e mortalidade - que envolvem direitos reprodutivos básicos, que não abarcam o direito ao aborto -, o país atingiu praticamente a igualdade. No entanto, no entanto, na dimensão das oportunidades econômicas, sua posição é a 91 ${ }^{\mathrm{a}}$, com o índice o,640 e na política, sua posição é a $86^{\mathrm{a}}$, com o índice 0,132 .

Embora mulheres e homens brasileiros tenham atingido a igualdade em relação aos anos de estudo, assim como em vários outros países do mundo, há ainda a concentração de mulheres em determinadas profissões e homens em outras, sendo que as últimas são mais valorizadas que as primeiras, configurando, assim, as consequências econômicas da denominada divisão sexual do trabalho. (BIROLI, 2017)

Dentre as quatro dimensões utilizadas no Fórum Econômico Mundial, a desigualdade entre homens e mulheres na representação política é a que 
apresenta scores mais baixos em todos os países e constitui a forma como as demais desigualdades se evidenciam e, provavelmente, um dos instrumentos importantes pelos quais elas permanecem, uma vez que os atores políticos que poderiam modificar a realidade, ao menos do ponto de vista político, continuam sendo predominantemente homens.

No presente capítulo, procurarei comparar a representação política no Brasil com a de países que adotam sistema eleitoral parecido com o nosso: o sistema eleitoral proporcional de lista aberta. Poucos países no mundo adotam esse sistema. Muitos países que adotam o sistema proporcional, utilizam a lista partidária fechada como alternativa de escolha do eleitor.

Escolhi comparar o Brasil com a Finlândia, que ocupa boa colocação nos rankings de igualdade entre homens e mulheres no mundo e a Áustria, outro país que, embora considerado economicamente desenvolvido, apresenta índices de igualdade melhores que os nossos, mas não tão igualitários quanto os da Finlândia. Acredito que a comparação possa trazer elementos para o debate sobre nosso aprimoramento institucional.

\section{A representação política, a ponta do iceberg erigido pelas demais dimensões da desigualdade entre homens e mulheres}

Esta é a dimensão em que o Brasil se encontra na pior posição em rankings internacionais. Além do Fórum Econômico Mundial, já mencionado, A União Inter-Parlamentar - Inter-Parliamentary Union - apresenta, em um relatório de 2018, que a média mundial de representação parlamentar das mulheres em janeiro de 2018 era de $23,4 \%$, o que representa uma significativa melhoria, se comparado com o índice de julho de 1995, que era de 11,3\%. (INTER-PARLIAMENTARY UNION, 2018) Neste relatório, foram apresentados os avanços ocorridos nos países com eleições nacionais em 2017, o que não foi o caso do Brasil. No próximo relatório, é possível que haja alguma melhora na colocação desse índice, dado o incremento da representação das mulheres nas assembleias estaduais e na Câmara Federal dos Deputados. 
A representação política é uma das dimensões em que se verifica a desigualdade entre os sexos e que se expressa de forma provavelmente mais intensa. Utilizo aqui o termo "sexos" e não "gênero" porque a desigualdade se verifica entre os indivíduos a partir de sua determinação biológica, que se dá de forma binária. Se fosse levada em consideração a categoria gênero, com todas as suas nuances e todos os problemas que ela traz à binariedade homem/mulher, a situação da desigualdade entre os gêneros seria ainda mais dramática, pois praticamente não há transgêneros e lésbicas representantes e há uma baixa presença de deputados que se afirmam gays. Mas não é a representação dessas variadas e complexas formas de expressão de sexualidade e de estar no mundo que será objeto deste texto. O alvo será algo anterior e que se constitui como um problema presente em todo o mundo: a desigualdade de representação entre homens e mulheres.

Mas, se esse problema aparece após as mulheres terem direito a voto, direito este que se espraiou pelas democracias ocidentais somente no século XX - o primeiro país a conceder a franquia do voto às mulheres foi a Nova Zelândia, em 1893 -, a desigualdade de representação pode ser considerada como parte de toda uma estrutura de divisão sexual do trabalho que remonta à antiguidade. Nas sociedades antigas, de um modo geral, as mulheres não eram consideradas cidadãs e, a elas, eram reservadas as atividades da esfera doméstica. Com um mundo mais rigidamente dividido entre a esfera pública e a esfera privada, aos homens cabiam predominantemente as atividades contidas na primeira e às mulheres, na segunda. Ao longo dos séculos, a organização da produção se modificou, e com a criação e a expansão do mercado, inclusive do mercado de trabalho, as mulheres adentraram à esfera pública, principalmente para incrementar uma produção que já não podia mais contar exclusivamente com a participação masculina, e também para contribuir para a manutenção econômica da vida doméstica e para a sua reprodução.

A despeito dessa flexibilização de uma divisão que, na antiguidade, se apresentava como ontológica, entre espaço público e espaço privado, na contemporaneidade ainda não se escapa de uma divisão sexual do trabalho baseada na separação, ainda mais rígida do que as demandas por 
igualdade entre os sexos exigiriam, entre espaço doméstico e espaço nãodoméstico. (OKIN, 2001) Essa divisão ilumina o quanto as mulheres são consideradas, na maioria das organizações familiares, as responsáveis exclusivas pelos afazeres domésticos e, principalmente, pelas atividades de cuidado. Tal responsabilidade contribui para que as mulheres, nas suas demais atividades, enfrentem custos maiores e tenham de conciliar suas atividades profissionais fora e dentro do lar. (BIROLI 2016, 2017; HIRATA; KERGOAT, 2007)

A divisão sexual do trabalho não diz respeito somente à responsabilização das mulheres pela atividade doméstica, mas também à divisão de áreas do conhecimento e do mundo profissional destinadas mais a esse ou aquele sexo. Por exemplo, enquanto a engenharia, a construção civil, as atividades militares, são predominantemente exercidas por homens, as atividades relacionadas ao cuidado - enfermagem, professoras de nível fundamental, assistentes sociais, pedagogas, apenas para ficar com alguns exemplos - são, em sua maioria, exercidas por mulheres. Mesmo dentre profissões como professores universitários, médicos, advogados, há especialidades que podem ser consideradas de presença majoritariamente "feminina" ou "masculina".

Tal divisão poderia significar apenas a expressão de vocações distintas. No entanto, sabemos que aos afazeres domésticos e às atividades voltadas ao cuidado são socialmente atribuídos valores inferiores àquelas atividades propriamente da produção. E hááreas intelectuais que também são mais valorizadas e ocupadas de forma mais expressiva pelos homens. Portanto, há uma atribuição diferenciada de valor para as atividades consideradas "masculinas" em relação àquelas consideradas "femininas", com desvantagem para estas. Ou seja, as atividades desempenhadas pelas mulheres são menos valorizadas do que as desempenhadas pelos homens. E tal atribuição de valor inferior ocorre mesmo quando atividades semelhantes são desempenhadas pelos dois sexos. Como consequência disso, temos que, em todo o mundo, a diferença de salário entre homens e mulheres é estabelecida na razão de que estas recebem como remuneração, em média, o,8 do que eles recebem. 
Neste contexto, a representação política nas câmaras de representantes, - atividade pública por excelência, e exercida, em nosso mundo contemporâneo, por profissionais - pode ser considerada a ponta extrema em que as mulheres, ao adentrar essa esfera, se encontram em um lugar que não é reservado a elas. Assim como também não é reservado a outros grupos excluídos daquilo que se considera o padrão dominante das sociedades - o homem heterossexual e branco. Neste ponto, a literatura feminista, ao tratar da desigualdade de representação, deu importantes contribuições não só para a busca de uma maior igualdade entre homens e mulheres, nessa esfera, como também para uma maior igualdade geral de representação. Ao problematizar os obstáculos que as mulheres enfrentam para serem representantes, a própria representação política e a sua capacidade de refletir os diversos segmentos da população - sua dimensão especular - é colocada em cheque.

Não abordarei aqui o debate em ordem cronológica, mas partirei de uma abrangência mais ampla, para então atingir um debate mais específico sobre o que os representantes efetivamente representam ou deveriam representar.

Nancy Fraser, ao elaborar sua concepção abrangente de justiça, inclui a representação como uma das dimensões que se tornaram necessárias para a formulação de uma teoria da justiça que abrangesse as demandas dos diversos movimentos sociais, inclusive o feminista. A autora aponta que se a redistribuição se evidenciou como insuficiente a partir das demandas por reconhecimento que diversos grupos, entre eles dentre as próprias mulheres - lésbicas, transgêneros -, também estas duas dimensões não são suficientes para garantir os mecanismos de justiça necessários para abranger a necessidade de representação desses grupos, que inclusive é um mecanismo para que as outras dimensões possam ser atendidas. Em outras palavras, a representação pode contribuir para uma maior equidade na justiça propriamente distributiva e também para o reconhecimento das e o respeito às diferenças e identidades dos diversos grupos. (FRASER, 2009)

A respeito do debate da representação propriamente dita, muito foi debatido, a partir da pergunta se haveria interesses específicos das mulheres e, se eles existem, se a presença delas nos órgãos de representação 
seria o mecanismo adequado para a representação desses interesses. Esse debate remete, ainda, a um debate sobre o que se espera de um (a) representante: que ele represente os interesses de seus (suas) representado(s) $\mathrm{s}$, ou que, após eleito(a), ele(a) represente o interesse de todos, ou seja o interesse público.

Virginia Sapiro (1998) enfrentou a questão, e apontou que, apesar de ser possível afirmar que há interesses das mulheres, não é possível afirmar, da mesma É a forma, que elas sejam conscientes deles e sejam as suas melhores defensoras. A condição de mulher é diferente da condição de feminista, e não há garantia de que uma mulher seja mais feminista que um homem e, para afirmar isso, ela invocou uma literatura nos anos 1970, que apontava que poucas mulheres eleitas queriam ser identificadas como defensoras das causas femininas per se.

De forma mais aprofundada e detida, Anne Phillips dedicou boa parte de sua reflexão sobre a democracia à representação feminina. Em Engendering Democracy ela afirma a necessidade de que a igualdade de oportunidades - entre elas a de ser representante - deva também ser estendida às mulheres. (PHILLIPS, 1991) Com isso, ela aponta para a legitimidade dos mecanismos de ação afirmativa para garantir tal representação. Em trabalhos posteriores, sua reflexão foi se tornando mais sofisticada e envolveu um debate sobre representação em que se confrontavam duas posições: na representação das mulheres deveria ser dada uma ênfase à representação de ideias feministas, ou simplesmente uma maior presença das mulheres já seria uma meta a ser alcançada? Essa dicotomia, entre uma política das ideias e uma política da presença - sendo que esta remonta à concepção de representação simbólica, na classificação canônica de Hannah Pitkin (1995) - foi explorada em seu The Politics of Presence, em que suas reflexões se estendem para grupos étnicos e raciais. Nele, é colocada em uma tensão - sem que seja definitivamente feita a opção pela defesa de um ou outro elemento da dicotomia - em que é apontada a importância de que os diversos grupos estejam presentes nas câmaras representativas - o que, de uma certa forma, reforça o caráter especular do sistema representativo, eminentemente o proporcional -, mas que é igualmente importante que ideias feministas sejam defendidas. 
$\mathrm{Na}$ literatura de países que implementaram o sistema de cotas (CAMINOTTI, 2013) é apontado que a maior presença das mulheres teria contribuído para que pautas feministas fossem abordadas e seus interesses fossem protegidos. Mas tal afirmação é sempre de difícil demonstração, pois, para prová-la, o mesmo assunto deveria ser submetido a uma outra câmara em que hipoteticamente, no lugar de mulheres, houvesse homens, e, neste caso, a matéria não fosse aprovada. No entanto, do ponto de vista histórico, a literatura aponta correlação entre o aumento de representação das mulheres e avanços em pautas consideradas feministas. De qualquer forma, na situação atual em que a representação se encontra, parece evidente que há um déficit de representação dos interesses das mulheres. Como exemplo disso, podemos citar todas as questões ligadas aos direitos reprodutivos, especialmente ao aborto.

A despeito da riqueza deste debate, é possível, ainda, defender uma maior participação das mulheres como representantes pelo simples fato de que elas também têm a liberdade de serem representantes. Ainda que entendamos que os representantes, após eleitos devam estar imbuídos de interesses públicos - e não parciais -, é possível argumentar: as mulheres também devem ter a liberdade de serem as representantes do interesse público, ou das causas “universais". (ABREU, 2011) A este ponto poderia ser apresentada a objeção: ora, mas nas sociedades democráticas não há nada que obste que as mulheres sejam representantes, a despeito dos resultados evidentemente favoráveis aos homens. E, nessas mesmas sociedades democráticas, como expressão da soberania popular, as preferências dos eleitores, expressas no voto, devem ser respeitadas. E, se as mulheres não se colocam como as melhores opções, não há por que sejam eleitas. De acordo com essa posição, o eleitor não escolheria entre homens e mulheres, mas o melhor candidato, de qualquer sexo.

O problema da aceitação dessa justificativa é que ela não problematiza o fato de as mulheres não se candidatarem. Seria simplesmente falta de interesse? A realidade de países que passaram por dizimações de população masculina em decorrência de guerra, como é o caso de Ruanda, e de países que adotaram percentuais ousados de reserva de vagas para candidaturas de mulheres é de que não faltaram candidatas. Então, pode-se 
dizer que há contextos sociais e, principalmente, institucionais, mais ou menos favoráveis à candidatura de mulheres. Esses contextos institucionais são definidos principalmente pelos partidos. (NORRIS, 2013)

No mundo, pode-se dizer que não há país que atingiu a igualdade de representação política tanto em cargos eletivos quanto em cargos administrativos. Aqueles países que conquistaram a igualdade em sua câmara de representantes o alcançaram por meio de algum mecanismo de cotas para mulheres, seja nas leis que disciplinam os partidos, seja com reservas de cadeiras nos lugares de representação sob escrutínio eleitoral. Estes são os casos de Ruanda, Bolívia (ABREU, 2015) e Costa Rica. (ABREU, 2010)

Estes mecanismos atingem seus objetivos ou por meio de reserva de cadeiras nas câmaras representativas, ou por meio da obrigatoriedade de que os partidos apresentem candidaturas de mulheres. Neste último caso, o sistema eleitoral proporcional de lista fechada tem sido o mais eficiente para garantir a efetiva participação das mulheres. Exemplos de países que tiveram sua representação aumentada, como foi o caso da Argentina, da África do Sul e de Marrocos, apenas para ficar com alguns exemplos. Na literatura internacional, é já reconhecido que os sistemas eleitorais majoritários são menos favoráveis à representação não só das mulheres, mas também de outros segmentos da população. Em relação aos sistemas proporcionais, há estudos indicando que magnitudes distritais médias (CAREY; HIX, 2011) são as mais adequadas para possibilitar uma representação política que reflita de modo mais ajustado os diversos segmentos da população. Dentre os países que utilizam o sistema proporcional, poucos são aqueles que utilizam o sistema proporcional de lista aberta. Um deles é o Brasil. Para analisar o que esse sistema eleitoral produz do Brasil, ele será comparado com dois outros, o da Finlândia e o da Áustria que, embora se apliquem sobre situações sociais bastante diversas, apresentam algumas regras institucionais semelhantes ao nosso, e outras diferentes. A comparação, provavelmente, irá propiciar uma melhor compreensão do funcionamento de nosso sistema e de seus efeitos sobre a presença de mulheres nas instâncias de representação. Passa-se, então, aos casos a serem analisados. 


\section{O Brasil e a representação política das mulheres}

Em 2018, no Brasil, mais especificamente no Rio de Janeiro, a comoção em torno do assassinato de Marielle Franco, vereadora eleita em 2016, com grande expressividade política, e também negra, favelada e lésbica, qualificações que reivindicava, colocou a discussão sobre a representação política em um outro patamar. Marielle representava não somente as mulheres negras pobres e lésbicas, mas todo um conjunto de pessoas que viu em sua atuação um novo modo de fazer política. Marielle, com sua presença, colocava no parlamento municipal os segmentos que representava. Com suas ideias, representava todos aqueles que desejavam uma cidade mais justa - uma conjunção da representação das ideias e da presença, para ficar com a classifica divisão feita por Anne Phillips. Sua base eleitoral não se resumiu à população que representava simbolicamente. De repente, boa parte da população do Rio de Janeiro, de homens e mulheres, homo ou hererossexuais, se viram representados por uma mulher negra, favelada e lésbica, identidade que reivindicava e da qual não abria mão. Uma barreira importante da representação política: os interesses da representação simbólica tornaram-se interesses gerais e universais. Ela tinha acabado de ser indicada relatora da Comissão parlamentar que iria acompanhar, na Câmara Municipal, a intervenção militar no Rio de Janeiro, e ela já vinha denunciando os abusos policiais que vinham ocorrendo em Acari. Tratava-se de um quadro político promissor, pré-candidata a vice-governadora pelo partido.

O caso extraordinário de representação empreendida de maneira exitosa por Marielle Franco, a ponto de sua morte ter repercussão internacional, não ameniza, no entanto, os baixos índices de representação política no Brasil. Dentre os indicadores utilizados pelo Fórum Econômico Mundial, é aquele em que o país se encontra em pior posição. Há três eleições nacionais consecutivas, a representação de mulheres na câmara de deputados não ultrapassa os 10\%. O crescimento da representação nas câmaras municipais, por sua vez, não pode ser considerado substantivo, nem mesmo consistente. É necessário esperar mais algumas eleições para verificar os efeitos das últimas manifestações feministas sobre a representação. 
Como já apontado, o sistema eleitoral brasileiro é proporcional de lista aberta. Em nossa lei, atualmente, é prevista uma cota de participação na lista de ao menos 30\% de candidatos/as de cada sexo. No entanto, coligações podem apresentar como candidatos um número equivalente a $150 \%$ das cadeiras em disputa. (ABREU, 2015) Isso faz com que cada partido possa de fato apresentar candidatas mulheres, mas sem que elas sejam, de fato, candidatas competitivas. No Brasil, o índice de competitividade das eleições, - número de candidatos em razão do número de cadeiras em disputa, é bastante alto, em especial nos distritos em que a magnitude é maior. Além disso, a magnitude distrital - número de cadeiras a serem ocupadas - varia de 8 a 70 na Câmara Federal dos Deputados, de 24 a 94 nas assembleias legislativas, e de 9 a 55 nas câmaras de vereadores.

Pode-se dizer que nossa lei de cotas, por conta de nosso sistema eleitoral de lista aberta e do grande número de candidatos que cada partido/ coligação pode apresentar, não tem funcionado. Nas eleições deste ano, com a garantia de reserva dos recursos do fundo partidário para candidaturas de mulheres, houve um incremento de sua representação na Câmara Federal dos Deputados, de 51 para 77, e nas assembleias estaduais, de 119, para 161 (de um total de 1059) deputados. No senado, não houve aumento no número de eleitas e uma senadora já eleita deixará sua vaga para ocupar o governo do estado do Rio Grande do Norte. Com isso, temos em todo o Congresso Nacional cerca de $15 \%$ de presença de mulheres. Vejamos o que ocorre em dois outros países, com realidades sociais bastante diferentes, mas com sistemas eleitorais proporcionais de lista aberta, como o nosso. Examinemos a Finlândia e, posteriormente, a Áustria.

\section{A representação de mulheres em sistemas eleitorais proporcionais de lista aberta: os casos da Finlândia, da Áustria e do Brasil}

\section{Finlândia}

No ranking geral do Fórum Econômico Mundial de 2017, a Finlândia ocupava a $3^{\mathrm{a}}$ posição e, em relação ao empoderamento político, que leva em 
consideração a ocupação de posições ministeriais e, também, de representação política propriamente dita, ela ocupa a $5^{\text {a }}$ posição, com $42 \%$ de mulheres no Parlamento.

O sistema proporcional de lista aberta funciona na Finlândia desde 1906, quando as mulheres também adquiriram o direito de votar. O sistema adotado era então semelhante ao brasileiro. A diferença notável é que, desde 1978, os partidos não podem apresentar mais candidatos do que o número de vagas em disputa. Além disso, nos distritos menores, o número total de candidatos não pode ser maior que 14, o que obriga os partidos a fazerem coligações, ou apresentarem estrategicamente candidatos que tenham chances de vencer a disputa. Essa prática foi adotada com a intenção de que os candidatos que são apresentados por um partido tenham efetivamente representatividade no interior desse partido. No momento da escolha do eleitor, a competitividade intra-partidária já foi parcialmente resolvida, e ele pode escolher entre os tradicionais líderes partidários e nomes novos, apostando na renovação, sem ter de respeitar uma ordem partidária prévia.

No sistema político finlandês, são 200 representantes, em um sistema representativo unicameral. A Finlândia é uma república parlamentar unitária. Para as eleições, o território é dividido em 13 distritos. Com exceção da ilha de Aland, em que apenas uma cadeira é disputada, a partir de 2013, com a nova divisão distrital, válida para a eleição de 2015, a magnitude dos distritos varia de 7 a 35, de acordo com a população. (MINISTRY FOR FOREIGN AFFAIRS FOR FINLAND, 2018)

A quase paridade na apresentação de candidatos dos dois sexos foi uma conquista no país. Em 1986, houve um primeiro Equality Act, que, no entanto, estabelecia a igualdade política em termos muito genéricos. Tentou-se, por meio judicial, dar efetividade à igualdade pretendida pela reivindicação de igualdade. Foi somente em 2005 que se aprovou a exigência da presença de ao menos 40\% de mulheres em qualquer instância política do país, seja administrativa, seja representativa. Daí o sucesso das medidas na Finlândia. No ato de 2005, é previsto, em sua Seção $4^{\mathrm{a}}$ : que a composição dos corpos administrativos, que exercem autoridade pública, dos comitês governamentais consultivos, e todos os corpos 
administrativos dever respeitar a porcentagem de ao menos $40 \%$ para cada sexo, salvo casos que sejam justificáveis para uma situação representativa diferente.

Com esta medida, a Finlândia vem conquistando uma persistente maior participação das mulheres em suas câmaras representativas e também em seus órgãos de governo. Apesar de contar com um sistema eleitoral semelhante ao nosso, o controle sobre a disciplina dos partidos no que tange à igualdade entre os sexos, e até mesmo em relação à competitividade eleitoral interna a cada partido, é muito maior que em nosso sistema.

\section{Áustria}

No ranking geral do Fórum Econômico Mundial, a Áustria ocupa a $57^{\mathrm{a}}$ posição e, em relação ao empoderamento político, a 54 a . Esta comparação poderia sugerir que ela está melhor nos índices de empoderamento político do que nos demais. No entanto, em relação à educação e à saúde, o atingiu praticamente a paridade. O que ocorre é que, nestes campos, muitos países também o atingiram, então muitos possuem o score alto, embora não ocupem posições relativas altas.

Em relação ao empoderamento político, é necessário apontar que a Áustria, em seu sistema eleitoral, também utiliza o sistema proporcional de lista aberta. No entanto, diferentemente da Finlândia, não há qualquer cota obrigatória de apresentação de candidaturas, ou de ocupação de posições por sexo, e os partidos detêm grande poder sobre as listas partidárias.

São 183 membros do conselho Nacional, eleitos por um sistema proporcional de lista aberta. São nove distritos, cuja magnitude varia entre 7 e 36 . Há uma cláusula de barreira de $4 \%$ dos votos, para que o partido tenha representação. Na última eleição, em 2017, chamou a atenção que o partido neonazista finalmente conseguiu ultrapassar a cláusula de barreira, conquistando espaço representativo e demonstrando o avanço conservador naquele país.

Além da cláusula de barreira, há uma quantidade mínima de votos que cada candidato deve ter para conseguir ocupar o lugar de representação. No nível federal, essa “cláusula de barreira” [threshold] individual é de 7\%, 
de 10 \% no nível estadual e de 14\% nos distritos locais, com extensão territorial inferior à dos estados.

Este sistema faz com que a votação seja extremamente personalizada (EDER; JENNER; MÜLLER, 2014), e isso não tem contribuído para a representação das mulheres. Na última eleição, de acordo com o acompanhamento da Inter-Parliamentary Union (2018), houve um incremento de apenas pouco mais de 1\% na representação das mulheres. Além disso, os distritos de magnitude relativamente alta tendem a já não produzir mais uma representação efetivamente proporcional, mas a favorecer candidatos com bases eleitorais [constituencies] em seus respectivos locais, com forte identificação pessoal. Embora alguns partidos apresentem cotas voluntárias, elas não são suficientes para que a presença de mulheres no sistema representativo da Áustria seja tão expressivo quanto é na Finlândia.

\section{Voltando ao Brasil}

O que a comparação com os sistemas eleitorais da Áustria e da Finlândia, especialmente dando a esta sua perspectiva histórica, confirma, é que o desenho das instituições eleitorais pode ser determinante para a efetiva participação das mulheres. Mesmo em um sistema proporcional de lista aberta, é possível prever mecanismos que garantam a efetiva presença feminina no processo eleitoral e na representação política, como ocorre na Finlândia.

E o que impede que nossa lei de cotas efetivamente funcione?

Em primeiro lugar, é necessário ressaltar que, desde 1986, quando se iniciou a abertura democrática, com a eleição frequente, de 4 em 4 anos, e a pluralidade de partidos, o percentual de mulheres eleitas para deputadas federais tem sido bastante baixo, como mostra o gráfico a seguir.

É curioso notar neste gráfico que o percentual de participação das mulheres na Câmara Federal dos Deputados caiu em 1998, justamente no ano seguinte à lei que estabeleceu a primeira versão de nossa regra de cotas para os sexos nas candidaturas dos partidos. 
Gráfico 1 - Percentual de mulheres eleitas para a Câmara Federal dos Deputados no Brasil, desde 1986.

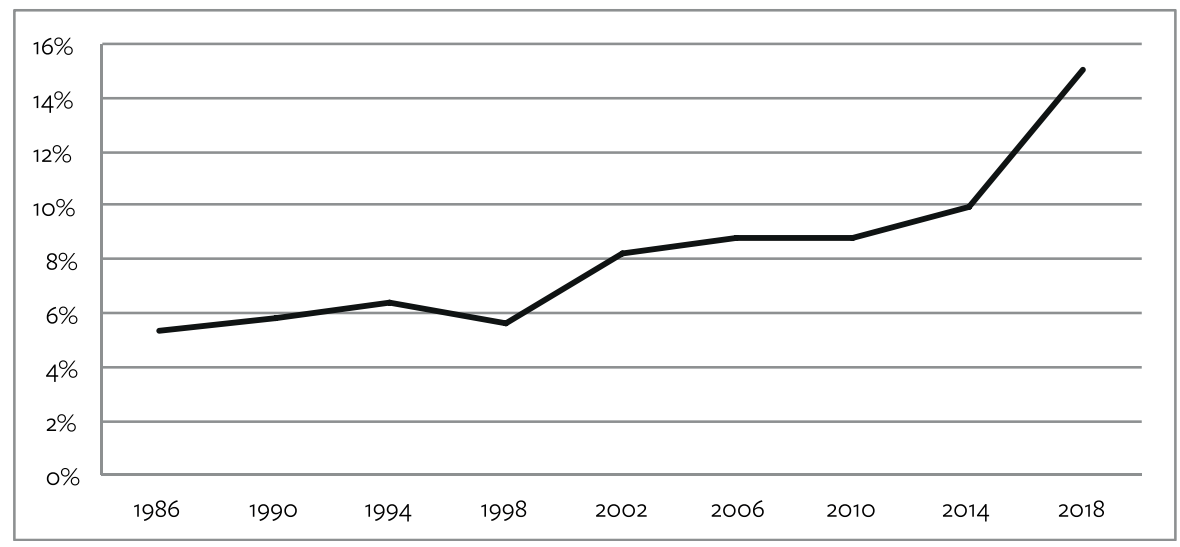

Fonte: TSE e Álvares, 2008.

Teria sido, então, o estabelecimento de um percentual mínimo de candidatos e candidatas uma medida equivocada? Pode-se dizer que não, pois até as eleições de 1994, o porcentual de mulheres candidatas também era muito baixo. Em 1986, foi de 6,5\%, em 1990 foi de 6,0\%, e em 1994, foi de 6,2\%. Então, na verdade, a baixa representação correspondia ao baixo percentual de candidaturas.

A Lei $n^{0} 9.504, / 1997$, a primeira a estabelecer algum tipo de cotas de sexo para as eleições no Brasil, ao definir o número de candidatos que cada partido poderia lançar, em cada disputa, estabeleceu, em sua redação original:

Art. 10. [...]

$\S 3^{\circ}$ Do número de vagas resultante das regras previstas neste artigo, cada partido ou coligação deverá reservar o mínimo de trinta por cento e o máximo de setenta por cento para candidaturas de cada sexo.

O uso do verbo reservar, combinado com o alto número de candidatos que cada partido poderia apresentar, foi interpretado pelos partidos 
como se $30 \%$ do total de candidatos que ele poderia apresentar devessem ser reservados para mulheres, e as candidaturas destas não precisassem ocorrer efetivamente.

O resultado de tal interpretação foi o de que, em 1998 tivéssemos apenas um total de 10,3\% de candidatas mulheres, para deputada federal e, em 2002, de 11,4\%, com praticamente nenhum partido aplicando a regra das cotas e nem por isso sofrendo sanções eleitorais por isso.

Por conta disso foi que em 2009 se alterou a redação de tal dispositivo legal para a seguinte forma, com a Lei $\mathrm{n}^{\mathrm{O}}$ 42.034/2009:

Art. 10. [...]

$\$ 3^{\circ}$. Do número de vagas resultante das regras previstas neste artigo, cada partido ou coligação preencherá o mínimo de $30 \%$ (trinta por cento) e o máximo de 70\% (setenta por cento) para candidaturas de cada sexo.

De fato, os partidos passaram a ofertar, entre as suas candidaturas, 30\% de mulheres. No entanto, várias delas receberam zero votos, o que indica que se tratava de candidaturas fictícias. Isso foi possível, porque a lei brasileira permite que o partido ou coligação apresente como candidatos o número de até $150 \%$ dos cargos em disputa, em alguns casos chegando a 200\%, de acordo com as regras do já referido artigo 10.

Isso quer dizer, em termos eleitorais, que se o número de cadeiras em disputa for, por exemplo, 10, cada partido ou coligação poderá apresentar uma lista com 20 candidatos. Se o número de vagas em disputa for 20 , o número de candidatos pode ser de até 30 . Ainda de acordo com essa lei, desses 20 candidatos, 6 deles deverão ser mulheres, em lista que será ordenada exclusivamente pelo voto nominal do eleitor. Ora, dificilmente um partido ocupará todas as vagas e, portanto, facilmente ele pode preencher todas as suas vagas com homens, sem que as mulheres tenham oportunidade, de fato, de sequer apresentar suas candidaturas, se a elas não forem dadas, no âmbito partidário, as mesmas condições de competição oferecidas aos seus colegas homens. Este quadro se agrava dada a variação da magnitude dos distritos eleitorais brasileiros, que vai de 8 a 
70. No caso do distrito mais populoso, São Paulo, onde há 70 vagas para deputado federal, uma mulher poderá ter de concorrer com 104 candidatos apenas de seu partido/coligação. Se essa candidatura não for apoiada pelo partido, ela (ou qualquer outro candidato homem), terá poucas chances de ter êxito. O diagnóstico que se tem do sistema brasileiro, que combina um sistema proporcional de lista aberta com a possibilidade de um partido oferecer um grande número de candidatos, é que a política de cotas tem sido inefetiva.

\section{Possíveis soluções para o sistema brasileiro}

A partir da constatação da inefetividade do nosso sistema de cotas, cabe, então, traçar possíveis cenários para a alteração desse quadro, embora a conjuntura política da atual legislatura da Câmara dos Deputados deixe poucas esperanças para que o atual quadro de baixa representação das mulheres se reverta. O primeiro cenário deve ser traçado a partir da permanência do sistema proporcional como está, com os mesmos distritos e com a lista partidária aberta. Nesse caso, a solução seria a reserva de cadeiras para as mulheres mais votadas da lista. Essa tem sido a reivindicação predominante da bancada feminina do Congresso, como será exposto adiante. Outra solução seria estabelecer a obrigatoriedade de destinação de parte dos recursos partidários para candidaturas de mulheres, e também a determinação de distribuição de tempo de tevê compatível com a promoção da participação das mulheres. Essa solução poderia acarretar uma modificação nos mecanismos de formação das preferências dos eleitores, além de dar maior visibilidade às mulheres já no momento das candidaturas. Um segundo cenário, pouco provável, seria a manutenção do sistema proporcional, com os mesmos distritos, mas com a adoção de listas partidárias fechadas. Nesse caso, devido à alta fragmentação do sistema partidário brasileiro, em que muitos partidos não conseguem eleger sequer três deputados em um distrito, a adoção de cotas de um terço continuaria produzindo poucos efeitos. Seria necessário, então, adotar a alternância entre os sexos, ou definir que, se dois forem os candidatos eleitos, um será mulher. 
Em um terceiro cenário, em que fosse adotado o sistema majoritário - distrital, na nossa linguagem jornalística -, o prejuízo para as mulheres seria inequívoco. A literatura internacional já consagrou que os sistemas majoritários são prejudiciais para a representação dos diversos grupos da sociedade, inclusive as mulheres. (NORRIS, 2004, 2011, 2013) No quarto cenário, com a adoção do "distritão", em que os eleitores passariam a votar em candidatos e não em partidos, permitindo que os mais votados numericamente, sem qualquer quociente partidário, ocupem as cadeiras disponíveis, a única solução possível é a reserva de cadeiras para as mulheres.

\section{A posição adotada pela bancada brasileira de mulheres, nos debates no congresso, desde 2015}

Diante do que era possível na pequena reforma eleitoral que o país passou em 2015, comandada por Eduardo Cunha, então presidente da Câmara dos Deputados, e das posições que foram por ele adotadas, a bancada feminina adotou como estratégia a defesa da reserva de cadeiras. Foi proposta, pela deputada Moema Gramacho (PT/BA), a Emenda Aglutinativa $\mathrm{n}^{\mathrm{O}}$ 26, que estabelecia: “Na composição de cada Casa Legislativa será assegurada a participação de no mínimo vinte por cento de membros de cada gênero, pelo período de 3 (três) legislaturas consecutivas, sendo vedada qualquer outro tipo de cota, na forma da lei". No entanto, mesmo essa proposta pouco ambiciosa em relação às demandas dos movimentos feministas, e também das políticas de cotas adotadas em outros países, não se demonstrou viável.

Foi então apresentada a Emenda Aglutinativa ${ }^{\circ}{ }_{58}$, que estabelecia: "Nas eleições para Câmara dos Deputados, Assembleias Legislativas dos Estados, Câmara Legislativa do Distrito Federal e Câmaras Municipais, para o período de três legislaturas consecutivas, será assegurada a eleição mínima de membros de cada sexo na circunscrição eleitoral respectiva, nos seguintes percentuais, desprezada a fração: I- dez por cento na primeira legislatura; II - doze por cento na segunda legislatura; e III - dezesseis por cento na terceira legislatura”. Não é possível deixar de notar que a referida proposta alteraria pouco o quadro da representação política por 
sexos no País. Apesar da ambição quase nula dessa proposta, ela foi derrotada na Câmara dos Deputados, pois obteve apenas 293 votos favoráveis, quando necessitava Na Comissão Temporária de Reforma Política do Senado, a segunda proposta foi aprovada, embora tenha havido manifestações, como a do Senador Aloysio Nunes, de que ela feria os princípios da democracia, pois o voto em uma mulher teria um peso maior do que o voto em um homem.

Nesta última eleição, foram feitas interpretações pelo Tribunal Superior Eleitoral das regras de financiamento de candidatos, de forma que fosse assegurado acesso aos recursos do fundo partidário por mulheres. Tal medida pode ter sido uma das causas para o aumento no número de deputadas, mas a extensão de seus efeitos positivos ainda deve ser devidamente mensurada. .

\section{Justificando as cotas}

Embora a participação das mulheres na representação política seja inferior à dos homens em praticamente todo o mundo, para muitos isso pode não se apresentar como um problema, uma vez que, nos países democráticos, as mulheres têm igual direito de candidatar-se. Além disso, interferir no processo de escolha do eleitor poderia ser considerado mais nocivo à democracia - que se assenta na liberdade dos indivíduos e na ideia "uma cabeça, um voto" - do que estabelecer regras atribuindo pesos diferentes a determinados candidatos. As principais objeções à adoção de cotas podem ser resumidas em três argumentos. 1. As mulheres têm igual oportunidade de candidatar-se; se não o fazem é porque assim não querem; então, não faria sentido “obrigá-las” a participar do processo eleitoral e, ainda mais, reservar lugares para elas. 2. Eleitores não votam em homens ou mulheres; votam em conjuntos de ideias, interesses, plataforma política, apresentados por um(a) candidato(a); dar vantagem às mulheres seria ferir o princípio democrático da livre escolha. 3. As mulheres são maioria do eleitorado. Se elas não votam em mulheres, por que reservar cotas? A primeira objeção não condiz com os relatos das mulheres que participam da atividade política, que sempre se referem às dificuldades 
para se firmar como candidata viável nos partidos. Além disso, a presença de mulheres nos movimentos sociais é muito mais expressiva do que nos cargos representativos, o que afastaria a ideia de que as mulheres não gostariam de participar da política. Se não se candidatam mais pode ser porque não recebem os devidos incentivos do partido, ou porque antecipem dificuldades que enfrentarão no processo eleitoral, inclusive para defender uma plataforma feminista. Estudo de Clara Araújo e Doriam Borges (2013) confirma o que estudo anterior, realizado em outro ambiente político e cultural (CHAPMAN, 1993), já apontava: quaisquer que sejam os atributos necessários para que se tenha sucesso em uma campanha eleitoral, os homens já vêm mais equipados por eles. Se analisados os perfis de homens e mulheres eleitos, eles são bastante parecidos, mas parece que há mais homens com as qualidades necessárias para se tornar viáveis eleitoralmente do que mulheres na mesma situação.

Tudo isto indica que, no recrutamento, os partidos optem por homens por eles se apresentarem mais viáveis para ser eleitos. Ora, mas esse não é um dado da natureza, que não deva ser questionado e transformado por instituições, se o que se pretende é promover uma maior igualdade de representação dos diversos segmentos da população, entre eles homens e mulheres. Essa e outras operações de cálculo estratégico político faz com que as opções que se apresentam ao eleitor já tenham passado por um crivo que assimila as constrições que as estruturas sociais oferecem a determinadas candidaturas. A afirmação contida na segunda objeção é verdadeira, mas ela não constitui obstáculo para que se implemente uma política de cotas. Ao contrário, se não há diferença entre os sexos para os eleitores, qual o problema, então, em, ao invés de um homem, se eleger uma mulher com a mesma plataforma política? O que tal objeção não leva em consideração é que, para chegar a ser uma candidata conhecida, a mulher tem mais dificuldades do que o homem. Entre outros fatores, porque o homem consegue ter uma vida partidária mais intensa, que provavelmente é proporcionada por ele poder delegar a suas esposas o trabalho doméstico - ou sua administração - e o cuidado com os filhos. A dificuldade enfrentada pelas mulheres ocorre mesmo se ela quiser defender plataformas gerais. Como o estudo de Araújo e Borges (2013) indica, as 
candidaturas femininas ainda são muito marcadas pela expectativa do familismo e da adoção de posições ligadas a questões sociais, e muitas vezes de assistência. A terceira objeção é talvez a de mais fácil afastamento. Se o que se pretende é implementar alguma medida "corretiva" para uma situação injusta de disputa eleitoral entre homens e mulheres, assim é porque se admite que, a partir de todas as situações sociais - as desigualdades entre homens e mulheres não são somente de representação, mas de remuneração, de segurança, de autonomia -, as mulheres são de alguma forma oprimidas, se não diretamente pelos homens, pelo menos por estruturas sociais que as coloca em posições de desvantagem e inferioridade. Se examinarmos a literatura sobre dominação e opressão, desde Weber (1996), passando por Bourdieu (1999), Tilly, 1998 e Bartky (1990). Quando Charles Tilly utiliza o conceito de "desigualdade categórica", o faz para afirmar, que o sujeito que se encontra na posição de dominado, oprimido ou inferiorizado na relação de desigualdade tende a emular o comportamento do dominador/opressor/superior, corroborando as estruturas de dominação/ opressão/desigualdade. Esse comportamento do oprimido é elemento essencial para que a opressão perdure. Portanto, culpar as mulheres pela não-eleição de suas colegas mulheres é culpar o próprio segmento inferiorizado pela desigualdade sofrida. Enfrentadas essas objeções, convém ainda ressaltar que a crença de que o voto do eleitor é livre de influências sociais e que a preferência se forma de maneira racional não resiste a uma análise detida e aprofundada dos mecanismos de funcionamento dos processos eleitorais no mundo contemporâneo. Sabemos que cada vez mais as campanhas são caras - e por isso o financiamento empresarial vem sendo também questionado -, os candidatos são produtos de propaganda, e a viabilidade de um candidato passa muito pelo grau de investimento que um determinado partido tem em relação a ele. Com isto, qualquer estímulo que se dê para que os partidos passem a apoiar candidaturas de mulheres pode significar uma reversão do atual quadro de desigualdade de representação. Por fim, as cotas são defendidas como mecanismo transitório até que os ambientes partidários sejam efetivamente mais igualitários e livres, não só para as investidas de 
homens e mulheres, mas também para os demais segmentos atualmente subrepresentados.

\section{Conclusão}

O Brasil está entre os países com os mais baixos índices de participação das mulheres na representação política. A despeito disso, em nosso contexto político, o debate sobre a implementação de cotas para que tal participação se amplie épouco ousado, resultando no aumento tímido que tivemos da presença de mulheres na representação legislativa, nestas últimas eleições.

O caso do Brasil ajuda a iluminar o quanto regras feitas tomando como referencial a liberdade partidária podem, na verdade, reforçar mecanismos sociais de padrão de comportamentos e, por que não dizer, de opressão. A lista proporcional aberta é justamente aquela defendida como a que confere mais liberdade ao eleitor e, na forma com que é adotada no Brasil, confere-lhe um sem número de opções.

No entanto, a teoria feminista já tem nos alertado que os mecanismos de preferência não são tão racionais quanto se supõe, e isso se reforça na arena eleitoral. Com a pouca informação acerca das regras eleitorais, a assimetria de poder econômico dos partidos e dos candidatos e das candidatas, e a concentração da visibilidade eleitoral das eleições majoritárias, a escolha dos parlamentares, no Brasil, se dá como um jogo de cartas marcadas em que poucas surpresas acontecem. Muitos candidatos são lançados tendo em vista a capilarização da campanha dos partidos, para que estes possam atingir o quociente eleitoral. Os critérios de prioridade de financiamento no interior dos partidos são muito pouco transparentes para o eleitorado.

Este não é exatamente um problema do sistema proporcional de lista aberta. Há como dar maior liberdade ao eleitor do que aquela garantida pelos sistemas eleitorais proporcionais de listas fechadas, mas com alguns limites aos partidos, como verificamos ser o caso da Finlândia. Em relação à igualdade entre homens e mulheres, é possível alcançar resultados substantivos fazendo alterações incrementais no sistema eleitoral, 
sem mudar suas características centrais. Mas os $85 \%$ de homens que hoje compõem a Câmara dos Deputados e o Senado terão de concordar com tal compartilhamento de poder. Seremos capazes disso?

\section{Referências}

ABREU, M. A. A. A minirreforma política de 2009 e as politicas de cotas de gênero para a Câmara dos Deputados. Brasília: IPEA, 2010. p. 589-599. (Brasil em desenvolvimento, v.3).

ABREU, M. A. A. Cotas para mulheres no legislativo e seus fundamentos republicanos. Brasília, DF: IPEA, 2011. (Texto para Discussão, n. 1645).

ABREU, M. A. A. Mulheres e representação Política. Revista Parlamento e Sociedade, n. 3, p. 27-44, 2015.

ÁLVARES, M. L. M. Mulheres brasileiras em tempo de competição eleitoral: seleção de candidaturas e degraus de acesso aos cargos parlamentares. Dados - Revista de Ciências Sociais, v. 51, n. 4, p. 895-939, 2008.

ARAUUJO, C.; BORGES, D. Trajetórias políticas e chances eleitorais: analisando o 'gênero' das candidaturas em 2010. Revista de Sociologia Política, Curitiba, v. 21, n. 46, p. 69-91, jun. 2013.

BARTKY, S. L. Femininity and domination: studies in the phenomenology of oppression. New York: Routledge, 1990.

BOURDIEU, P. A dominação masculina. Rio de Janeiro: Bertrand Brasil, 1999.

CAMINOTTI, M. La representación política de las mujeres en el período democrático. Revista SAAP, Ciudad Autónoma de Buenos Aires, v. 7, n. 2, 329337, nov. 2013.

CAREY, J.; HIX, S. The Electoral Sweet Spot: Low Magnitude Proportional Electoral Systems. American Journal of Political Science. v. 55, n. 2, p. 383-397, Apr. 2011

CHAPMAN, J. Politics, feminism and reformation of gender. London: Routledge, 1993. 
EDER, Ni.; JENNY, M. e MÜLLER, W. C. Winning over voters or fighting party comrades? Personalized constituency campaigning in Austria. Electoral Studies. v. 39, p. 316-328, 2015.

FRASER, N. Scales of justice: reimagining political space in a globalizing world. New York: Columbia University Press, 2009.

HIRATA, H.; KERGOAT, D. Novas configurações da divisão sexual do trabalho. Cadernos de Pesquisa, São Paulo, v.37, n. 132, p. 595-609, set./ dez. 2007.

INTER-PARLIAMENTARY UNION (IPU). Women in Parliament in 2017: the year in review. Genebra: IPU, 2018.

MINISTRY FOR FOREIGN AFFAIRS FOR FINLAND. Available on: $<$ http://formin.finland.fi/public/default.aspx?contentid $=58850$ \&nodeid $=$ 15998\&contentlan=2\&culture $=$ en-US $>$. Access on: 18 Apr. 2017.

NORRIS, P. Electoral engineering: voting rules and political behavior. Cambridge: Cambridge University Press, 2004.

NORRIS, P. Democratic Deficit: critical citizens revisited. Cambridge: Cambridge University Press, 2011.

NORRIS, P. Recrutamento político. Revista de Sociologia Política, V. 21, n. 46, p. 11-32, 2013.

OKIN, S. Gender, the Public and the Private. In: PHILLIPS, A. (Org.). Feminism and politics. Oxford: Oxford University Press, 1998. p. 116-140.

PHILLIPS, A. Engendering democracy. University Park: Pennsylvania University Press, 1991.

PHILLIPS, A. The politics of presence: the political representation of gender, ethnicity and race. Oxford: Oxford University Press, 1995.

SAPIRO, V. When are interests interesting? The problem of political representation of women. In: PHILLIPS, A. (Ed.). Feminism and politics. Oxford: Oxford University Press, 1998. p. 161-192.

TILLY, C. Durable Inequality. Berkeley: Universty of California Press, 1998.

TILLY, C. Democracy. Cambridge: Cambridge University Press, 2007. 
TSE. Tribunal Superior Eleitoral. Estatísticas eleitorais. Disponível em: $<$ http://www.tse.jus.br/eleicoes/estatisticas/estatisticas-eleitorais>. Acesso em: 18 abr. 2018.

WEBER, M. Economía y Sociedad. Mexico: Fondo de Cultura Económica, 1996.

WORLD ECONOMIC FORUM. Global Gender Gap Report. Genebra: WEF, 2017. 
REFLEXÕES SOBRE

IGUALDADE DE GÊNERO

E OS ORGANISMOS

INTERNACIONAIS

Ana Paula Martin Martins 
Em relatório publicado em 2018 pela Organização Internacional do Trabalho (OIT), publicado às vésperas do último Dia Internacional da Mulher, o gênero feminino ainda é menos propenso a participar do mercado de trabalho do que o masculino na maior parte dos países do mundo, constituindo-se ainda como o grupo que apresenta maior vulnerabilidade ao desemprego. Em 2018, a força de trabalho feminina alcançou a margem de 48,5\% no mercado, porém, num momento de retração do mercado mundial, a taxa de desemprego feminina se mostrou cerca de 0,8 ponto percentual maior do que a masculina. Em termos de distribuição geográfica, o desemprego feminino se mostra mais agudo em países em desenvolvimento, chegando a haver uma inversão dessas taxas nos países desenvolvidos, nos quais a margem de desemprego feminino chega a ser menor do que a margem masculina.

Ainda segundo o relatório, cargos de gestão são menos acessíveis às mulheres e a qualidade do trabalho bem como sua remuneração também se mostra bastante aquém da realidade de mercado para os homens. Em 2018, em comparação com os homens, as mulheres apresentam o dobro de chance de se tornarem trabalhadoras familiares não remuneradas, trabalho que, em países em desenvolvimento, representa $42 \%$ do emprego feminino, sem perspectivas de melhora até 2021.

Os desafios da igualdade de gênero no campo do mercado de trabalho estão diretamente ligados à necessidade de avanços no campo da educação. Se, por um lado, o momento presente registra um cenário de avanços sem precedentes para a mulher ao longo da história, o acesso à escolaridade e a permanência na escola não é isonômico na questão de gênero. De acordo com estudo da Organização das Nações Unidas (ONU), de 2017, em termos de estudo superior especializado, somente 18\% dos títulos de graduação em Ciências da Computação são auferidos por mulheres, sendo que estas ocupam apenas $25 \%$ das vagas de trabalho da indústria digital. Na área da pesquisa os dados também não são interessantes: apenas 30\% dos pesquisadores que defendem suas bancas de trabalho no mundo, hoje, são atribuídos a mulheres. (NAÇÕES UNIDAS, 2018)

O relatório da OIT de 2010, intitulado "Mulheres no mercado de trabalho: medindo progresso e identificando desafios" demonstra que, 
apesar do aumento da participação da mulher trabalhadora, com exceção de parte da Europa e leste da Ásia, a taxa de crescimento vem caindo em quase todas as regiões nos últimos anos. Sendo assim, a mulher vem enfrentando dificuldades no mercado de trabalho, sendo colocada em posições inferiores e ganhando salários baixos, muitas vezes atribuídos pela necessidade de lidar com a dupla jornada de trabalho que as responsabilidades familiares lhes trazem. (NABESHIMA, 2014; ORGANIZAÇÃO INTERNACIONAL DO TRABALHO, 2016)

Em que pese todo o progresso realizado desde o final do século XX na questão da igualdade de tratamento nas relações de gênero, as perspectivas da mulher no campo do trabalho ainda se distanciam muito do que seria ideal numa perspectiva isonômica entre gêneros. As estatísticas demonstram que a situação está longe do que seria o ideal, sendo a "Igualdade de Gênero" por esse motivo, adotada na Agenda 2030 das ONU para o Desenvolvimento Sustentável como um objetivo específico, qual seja: "Até 2030, alcançar o emprego pleno e produtivo e trabalho decente para todas as mulheres e homens, inclusive para os jovens e as pessoas com deficiência, e remuneração igual para trabalho de igual valor." (ODS 8.5). Nesse contexto, o presente capítulo refletir sobre os avanços e desafios da igualdade de gênero no campo das organizações internacionais bem com os mecanismos para a implementação de políticas públicas igualitárias.

\section{Política internacional para a igualdade de gênero}

O século XX tem como marca inequívoca a conquista de direitos femininos. No campo internacional a afirmação desses direitos ganharam reconhecimento das Organizações Inernacionais que se institucionalizavam e se proliferavam após as duas guerras mundiais. A criação da OIT, em 1919, inicia sua luta igualitária prevendo proteção a maternidade, relativização do trabalho noturno e vedação de trabalhos penosos à mulher (Convenção n.3 - 1919). Após a Segunda Guerra Mundial, frente a reestruturação jurídica e política do mundo pós-guerra, influenciado pelos clamores de paz e justiça social, a OIT prevê a igualdade de remuneração 
e não discriminação em matéria de emprego e profissão (Convenção n.100-1951 e Convenção n. 111-1958). Mas foi na década de 1970, impulsionada pelo movimento feminista, que o assunto passou a ser tratado com maior relevância na Conferência da Cidade do México (Primeira Conferência Mundial sobre a Mulher - 1975), o que influenciou a ONU a adotar a Convenção sobre a Eliminação de todas as formas de Discriminação contra a Mulher (CEDAW), de 1979, considerado o mais forte instrumento contra as formas de discriminação da mulher, até hoje adotado, influenciando modificações nas legislações internas dos Estados-membros.

O período compreendido entre 1976-1985, conhecido como Década da Mulher foi marcado pela aprovação de mais três convenções mundiais sobre o tema (Copenhagne-1980, Nairóbi-1985, Pequim-1995), sendo que a nomenclatura antes sedimentada como a luta contra "discriminação contra a mulher”, ganha base principiológica e jurídica, e é alterada pelo termo "igualdade de gênero", o que influencia outros documentos a tratar o assunto como uma questão de justiça social e equanimidade, tal como ficou consolidado na Declaração do Milênio (2000), que estabelece entre suas metas a promoção da igualdade de gênero e o empoderamento da mulher. (NABESHIMA, 2014, p. 17) Mas, em termos de efetividade, apesar da Carta da ONU (1945) fixar como norma fundamental da comunidade internacional a igualdade de tratamento à mulher, foi a Declaração Universal dos Direitos Humanos (1948) que se revelou um marco definitivo no assunto, por incluir o direito da mulher, definitivamente, no rol dos Direito Humanos. (MAGALHÃES, 2016)

Embora esse declaração não tenha efeito jurídico vinculativo, ou seja, o seu descumprimento não é considerado violação à tratado internacional ou resolução da ONU, por se tratar de mera declaração, ela passou a ser interpretada, ao longo do tempo, como manifestação expressa e autêntica da comunidade internacional em matéria de direitos humanos, o que lhe conferiu certa efetividade. Destaca-se, nesse contexto de fixação de rumos universais de tratamento, o papel desempenhado pelos países latino-americanos, pois foram os primeiros a tomar medidas reais para ganrantir a igualdade de gênero, por meio de convenções que pactuaram entre si, tal como a Convenção Interamericana da Mulher (Bogotá, 1928), 
a Convenção Interamericana de Montevidéu (Montevidéo,1933), que estabeleceram direitos de nacionalidade à mulher e a impossibilidade de sua alteração em razão de casamento; e ainda a IX Conferência Internacional Americana (Bogotá, 1948), a qual aprovou a Convenção Interamericana sobre Concessão de Direitos Civis à Mulher.

Entre outros documentos internacionais do século XX, que visaram estabelecer tratamento digno à mulher relativos ao casamento, divórcio, filhos e manutenção da nacionalidade da mulher casada, além de impedimentos ao tráfico de mulheres, estão o reconhecimento dos direitos políticos da mulher. Sua atribuição consagrou-se um dos instrumentos mais poderosos de efetividade da igualdade de gênero, não só por garantir às mulheres o direito de voto e escolha de seus representantes, mas por permitir-lhes, pessoalmente, fazer e ser a própria representação do gênero. A atividade da mulher na política dentro dos Estados Nacionais é icônica, sobretudo, por ser uma chave capaz de gerir dois benefícios: a propulsão da igualdade de gênero, através de sua atividade política e seu empoderamento frente à sociedade, pelo exercício do cargo político.

\section{Do global ao local: desafios da aplicação das normas}

Apesar da Convenção sobre Direitos Políticos da Mulher ter sido aprovada pela Assembleia Geral da ONU em 1952, e ter entrado em vigor desde 1954, já contando com um número expressivo de ratificações, as mudanças efetivas no ordenamento jurídico nacional de cada um dos países signatários mostrou-se um processo lento e penoso. Vale lembrar que o tratamento igualitário perante a lei não equivale ao tratamento igualitário na lei. (MAGALHÃES 2016, p. 223) Apesar de ratificar declarações e tratados regionais e globais que dão igualdade de direitos ao homem e a mulher desde a primeira metade do século XX, o Brasil arrastou reformas à sua legislação, promovendo alterações mais efetivas somente a partir da década de 1960 com O Estatuto da Mulher Casada (1968) e, posteriormente, com a Emenda Constitucional n. 09 (1977) que introduz o divórcio no Brasil. Outros institutos mais contundentes se efetivaram a partir 
da Constituição do Brasil de 1988, que consagra a isonomia como forma fundamental de tratamento.

Um dos elementos essenciais da sociedade democrática é a inclusão de sujeitos representantes de diversos grupos sociais em cargos de representação, principalmente, no poder legislativo. O reconhecimento da existência de fronteiras entre espaço público e privado, fez com que a reflexão sobre igualdade de direitos de gênero não fosse somente garantida no espaço privado, na relação familiar e profissional, mas também no espaço público de tomada de decisão e representação política. A presença da mulher na política possibilita a publicização do processo histórico e cultural de dominação e subjulgação da mulher, fomentando-se uma cultura de paz, igualdade e dignidade substitutiva para tal desequilíbrio social. É notório porém, que o conjunto “mulher” também compõe-se de uma série de sub-grupos estratificados, mas que podem ter na representação feminina genérica voz e vez para propor projetos de lei e políticas públicas que atendam as suas necessidades genéricas e específicas.

As mulheres representam mais da metade da população brasileira (51\%) e também são a maioria do eleitorado do país (52,05\%), no entanto, são poucas as mulheres que têm acesso às instâncias legislativas nacional, estadual e municipal. Segundo dados do TSE, nas últimas eleições para prefeito e vereador (2016), 68\% dos candidatos eram homens e $32 \% \mathrm{mu}$ lheres. Da disputa, 68\% dos eleitos foram homens e somente $13 \%$ mulheres. (BRASIL , 2016)

A desproporcionalidade na representação por gênero configura uma séria falha na democracia. A sub-representação por gênero é uma realidade em grande parte dos países, o que provocou a estruturação de medidas políticas para suavizar tal deformação, adotadas por mais de 130 países nos últimos vinte anos. Dentre essas medidas, a mais comum é a que condiciona os partidos políticos a lançarem candidaturas com uma percentagem mínima reservada a candidatas mulheres, de $30 \%$ ou, mais recentemente, de 50\%. (RAMOS, 2015)

De acordo com o Women in Politics Map do Inter-Parliamenty Union (IPU) e a UNWomen (2017), o número de mulheres no poder executivo e no parlamento num estudo comparativo entre vários países teve um leve 
crescimento, de 2015 para 2017, dado amparado pelas políticas públicas aplicadas com reserva de candidaturas. A percentagem de crescimento de mulheres em cargos de poder executivo e parlamento passou de uma média global de 22,6\% (2015) para 23,3\% (2017). O mesmo estudo reflete também que, por um lado, o número de candidaturas femininas cresceu, mas por outro, o número de mulheres que chegaram ao poder decresceu em relação à percentagem de candidaturas femininas no período. O Brasil ocupa no ranking do IPU a $152^{\circ}$ posição de 198 países, quanto ao número de mulheres no parlamento e nos cargos do poder executivo. Em 2018, 14,8\% das cadeiras do Senado (12 do total de 81 ) e 10,4\% das cadeiras na Câmara dos Deputados (55 do total de 513) eram ocupadas por mulheres. (INTER-PARLIAMENTY UNION, 2018)

A fim de compensar essa deformidade representativa por gênero e efetivar o princípio da igualdade constitucional (art. $5^{\circ}$, caput e inc.I, $\mathrm{CF} / 88$ ) ou, pelo menos, reduzir a desigualdade historicamente acumulada, é necessária a implantação de estratégias de uma gama de possibilidades, quais sejam: (1) a implantação de políticas públicas que estruturem um nível de equivalência entre gêneros através de normatização; (2) a promoção de ações afirmativas em prol da mulhe, como política de cotas ou de metas, e ainda, (3) prover a tutela processual da causa feminina, garantindo-lhes o direito de ação frente à violação de suas garantias e direitos previstos em normas nacionais (regras e princípios) e tratados internacionais de direitos humanos ratificados e internalizados.

A título de exemplo, no Brasil promulgou-se uma lei, a Lei n. 12.034/2009, ${ }^{1}$ a fim de dar equilíbrio de gênero na representação política dentro do Estado. A lei impõe aos partidos e coligações o preenchimento do número de vagas de no mínimo 30\% e máximo 70\% para candidatos de cada um dos sexos. Essa medida, se por um lado visa garantir a oportunidade de mulheres participarem do processo de política partidária e da

1 Art. 10, $\S 3^{\circ}$ da Lei n. 12.034/2009 que Altera as Leis n ${ }^{\circ 5}$ 9.096, de 19 de setembro de 1995 - Lei dos Partidos Políticos, 9.504, de 30 de setembro de 1997, que estabelece normas para as eleições, e 4.737, de 15 de julho de 1965- Código Eleitoral: “Art.10,\$3: "Do número de vagas resultante das regras previstas neste artigo, cada partido ou coligação preencherá o mínimo de $30 \%$ (trinta por cento) e o máximo de 70\% (setenta por cento) para candidaturas de cada sexo". 
disputa eleitoral, por outro não garante o efetivo preenchimento da vaga, já que cabe ao cidadão a escolha última por quem quer ser representado.

Críticas à essa política pública existem por entender que, apesar da exigência, faltam condições de campanha, espaço político e igualdade de oportunidades para as mulheres consolidarem suas campanhas e conquistarem efetivamente o eleitorado. Outros criticam a fiscalização desse sistema, pois muitas candidaturas femininas no Brasil são, em verdade, fictícias já que certas legendas lançam campanhas pró-forma com o único objetivo de cumprir a cota imposta pela lei. Há ainda, uma crítica de cunho mais técnico que entende que o desenho do sistema proporcional eleitoral brasileiro, a sua estrutura partidária e o mecanismo de seleção de candidatos não auxilia a política pública, bem como aponta-se um defeito na própria norma, que se isenta de apresentar sanções aos partidos políticos que descumprirem o percentual mínimo de candidatas.

No âmbito da gestão do poder no ambiente público, a mulher brasileira, devido à entrada pelo sistema de concurso público, tem presença mais marcante (39,7\% são mulheres), já que seu nível de escolaridade é mais alto do que o dos homens. Porém, quanto à presença da mulher na gestão do poder no ambiente privado a situação se agrava novamente. Apesar da mulher brasileira corresponder a quase metade da força de trabalho nacional, ela ocupa somente $37 \%$ dos cargos de direção e gerência e, no topo dos comitês executivos de grandes empresas, elas são apenas 10\%, ganhando cerca de $76 \%$ a menos do que os homens que ocupam o mesmo cargo. (ALMEIDA, 2017) Há uma grande variação da participação da mulher na gestão do setor privado ao redor do mundo. A média mundial está em torno de $24 \%$ de participação (que incluem presidentes, vice-presidentes e diretorias), tendo como país mais bem posicionado no ranking a Noruega com $33 \%$ de mulheres no comando de empresa e o Japão, como país pior posicionado, com apenas $2 \%$. (BELMONTE, 2014)

Simone de Beauvoir (2016), em seu célebre livro O segundo sexo, defende que o trabalho é fundamental à mulher, pois somente este poderia dar a mulher a liberdade concreta. No entanto, tal afirmação segue com a consciência da delicada posição que a mulher se encontra no mundo profissional, tendo que acumular afazeres domésticos com demandas 
profissionais, sofrendo, ainda, pressão familiar e conjugal, para manter “qualidade" de seus múltiplos papéis sociais. São muitos fatores de origem cultural que envolvem o tema de gênero e que influenciam no desenvolvimento da mulher e sua participação no mercado de trabalho a fim de garantir sua independência econômica, social e emocional. ${ }^{2}$

\section{A presença feminina nas organizações internacionais}

Analisando os dados acima, a participação da mulher no ambiente de trabalho público ou privado de forma igualitária ainda se encontra incipiente, porém em evolução. Desafios para a efetivação da igualdade de gênero e empoderamento da mulher existem e devem ser promovidos através de campanhas mundiais para a propagação da mudança de cultura e tratamento jurídico. Embora as Organizações Internacionais desempenham um papel de protagonismo na propulsão dessas políticas púbicas ns Estados, vale questionar como é sua própria composição no tocante à promoção da cultura da igualdade de gênero, especificamente aos seus quadros.

O questionamento parece ser bastante coerente, uma vez que, quanto maior equilíbrio de gênero nos próprios quadros dos Organismos Internacionais responsáveis pela propagação da cultura da igualdade de gênero, maior representatividade internacional a política teria e, por conseguinte, maior efetividade de implantação. Historicamente, o primeiro instrumento que dá à mulher a mesma condição do homem nos Organismos Internacionais é o Pacto das Nações, documento responsável por criar a Sociedade das Nações em 1919. O artigo $7^{\circ}, \$ 3^{\circ}$ do Pacto estabelece que todas as posições administrativas da Liga das Nações, inclusive o Secretariado, seriam abertos aos homens e às mulheres em condições

2 A preocupação com a mulher e o ambiente cultural que a envolve é pauta razoavelmente recente, inclusive, no direito internacional. A primeira diretriz acerca da mulher refugiada e dos motivos ligados ao gênero que impossibilitam a continuidade de sua permanência no país de origem datam de 1990. O interessante estudo de Thais Severo (2014) aprofunda a questão, demonstrando a importância do discrimen nesse caso, já que, em 2013, 49\% da população de refugiados são meninas e mulheres, segundo o Alto Comissariado das Nações Unidas para refugiados (ACNUR). 
iguais. Portanto, desde o início do século XX, a mesma oportunidade de compor a representação internacional foi garantida a ambos os sexos por uma medida de inserção de política pública por via da normatização.

A Organização Internacional do Trabalho, por meio da da Declaração da Filadélfia de 1944 também se ocupou do tema do preenchimento de seus quadros, demonstrando preocupação com o tratamento igualitário, compreendendo não só dar a oportunidade de participação da mulher nos quadros, como previu a necessidade de garantir a igualdade de direitos remuneração e oportunidades, dando a ambos os sexos, um tratamento legal igualitário.

No âmbito da Organização das Nações Unidas, embora a preocupação com a igualdade de gênero esteja presente desde o texto da Carta de 1945, a paridade entre homens e mulheres nos quadros da instituição ainda é uma meta a ser alcançada. É certo que, desde 1945, muito se avançou e o reforço à candidaturas do sexo feminino é assinalado nos diversos processos seletivos. Contudo, é possível afirmar que os passos mais decisivos foram dados muito recentemente, no mandato do atual Secretário-Geral Antonio Guterres que elevou de 16 para 23 o número de mulheres trabalhando em seu gabinete (de um total de 44 pessoas), bem como o objetivo de alcançar a paridade nos níveis superiores da organização até 2021 e em toda a organização até 2028. Apesar de nenhuma mulher ter chegado ainda à Secretária-Geral da Organização, as medidas recentes assinalam um avanço histórico e reafirmam a importância de atuar dando o exemplo das ações que defende.

A função diplomática no mundo foi considerada até meados do Século XX uma profissão ligada ao gênero masculino. Nos EUA, a primeira mulher a ocupar um cargo diplomático foi Ruth Bryan Owen, em 1934, quando ocupou o posto na Dinamarca. Na França, a primeira mulher a ocupar um cargo diplomático foi Suzanne Borel em 1930, mas cargos mais altos somente foram ocupados por mulheres em 1972, como Marcelle Campana, embaixadora no Panamá e Isabelle Renouard, em 1986, quando foi nomeada diretora da Administração Central. (RÉPUBLIQUE FRANÇAISE, 2018) No Reino Unido, o cargo foi assumido por mulheres a partir de 1946, porém a proibição de casamento para mulheres em função 
diplomática somente foi abolida em 1972. Na Espanha e Itália, na década de 1960. A nomeação da britânica Catherine Ashton, em 2009 ao posto de Alta Representante da União Europeia tornou-se um símbolo político. Ela foi substituída em 2014 por uma italiana, Federica Mogherini.

Mas, apesar dos esforços, a feminilização da profissão é muito lenta. Nos anos 1990, cerca de 11\% dos embaixadores do Reino Unido eram mulheres. Na França, 14\%. Os motivos apontados por esse atraso da participação da mulher na carreira diplomática estão na difícil conciliação da vida familiar e da carreira professional e na proibição legal que muitos países praticaram até poucos anos atrás. A presença da mulher na diplomacia brasileira iniciou-se em 1918, com o ingresso da primeira mulher no concurso para o Itamaraty, tornando-se também a primeira funcionária pública federal. Embora o acesso à carreira tenha sido vedado às mulheres entre 1938 a 1953, nas últimas décadas as diplomatas mulheres conquistaram espaço e notoriedade. (FRIAÇA, 2018) Em 2016, havia 355 mulheres diplomatas em atividade, para um total de 1.571 diplomatas, correspondendo a 22,6\%. Entre as turmas de 1953 e de 2015 do Instituto Rio Branco, 427 mulheres ingressaram na carreira diplomática, de um total de 2.126, correspondendo a 20,1\%. (BRASIL, 2018) Mulheres diplomatas brasileiras têm tido destaque no tratamento de temas relacionados à paz e à segurança ${ }^{3}$ internacionais pelo Itamaraty, inclusive em posições de comando.

\section{Mecanismos para a promoção da igualdade de gênero}

A promoção da justiça equitativa em matéria de gênero tem sido fomentada por meio de mecanismos de difusão, coerção e aplicação, tais como: 
(a) a implantação de políticas públicas por normatização que estruturem um nível de equivalência entre gêneros; (b) a promoção de ações afirmativas em prol da mulher; e (c) tutela processual da causa feminina no âmbito nacional e internacional.

Dentre as principais formas da promoção da justiça social equitativa em matéria de gênero encontramos a amplamente utilizada "oportunidade de ingresso" implantada por normatização. No plano internacional, os Estados se comprometem com o respeito aos direitos humanos (liberdades individuais, paz entre os povos, justiça social e sustentabilidade ambiental). Ocorre que a simples normatização não garante a efetividade da implantação da medida por ao menos dois motivos: a ausência de uma sanção contundente, que provoque a obediência a norma prevista, ou porque as vagas acabam não sendo preenchidas pelas candidatas ao emprego ou cargo de gestão de âmbito público ou privado ou cargo eletivo de âmbito público, pela falta de conhecimento técnico (deficiência na formação), capacidade de dedicação para o trabalho (dada a jornada dupla feminina) ou pela falta de elegibilidade (por preconceitos socioculturais).

Entre as políticas públicas presentes no Sistema Internacional de proteção dos Direitos Humanos estão as chamadas ações afirmativas, consideradas "medidas especiais", temporárias e dirigidas à proteção e ao desenvolvimento de determinadas minorias sociais e étnicas estabelecidas por intermédio de Convenções e Convênios. Os principais documentos internacionais que exteriorizam as "medidas especiais" são: a Convenção Internacional sobre Eliminação de Todas as Formas de Discriminação Racial, adotada pela Resolução n. 2.106-A da Assembleia das Nações Unidas (1965); a CEDAW, adotada pela Assembleia Geral da ONU plena Resolução 34/180 (1981), que prevê as "medidas apropriadas, inclusive de caráter legislativo e "medidas especiais de caráter temporal”; Recomendação Geral do Comitê para a Eliminação da Discriminação contra as Mulheres (2004), ${ }^{4}$ com previsão de "medidas" como tratamento

4 Devido à polêmica gerada em torno do sistema de cotas, o documento de 2004 preferiu utilizar o termo genérico "medidas" para contar com a criatividade legislativa dos estados, evitando expressões conhecidas como affirmative action, positive action ou positive discrimination já desenvolvidas por juristas. (MADUGRA, 2013, p. 192-193). 
preferencial, formas de recrutamento e promoção, sistema de cotas ou metas. ${ }^{5}$

A reserva de cotas é considerada a mais polêmica das medidas, porém bastante implantada para compensar discriminações oriundas de questões raciais e desnivelação social, tal como a questão de cotas no Ensino Superior em diversos países, como nos EUA e alguns países europeus. A discussão de cotas raciais ${ }^{6}$ e sociais no Ensino Superior no Brasil dentre outras reservas, por exemplo para as pessoas com deficiência, coloca em voga os fundamentos da adoção dessa política pública considerada a mais ostensiva em termos de garantia de isonomia. A discussão da implantação de cotas raciais no Ensino Superior no Brasil é tema ainda polêmico, pacificado com o julgamento da ADPF 186, STF (abril, 2012), entendida constitucional e como uma política legítima e hábil para promover a justiça distributiva no país. Nesse contexto, de um lado "as cotas sociais possuem o condão de trazer alunos de menor renda e do ensino público para as universidades, sem se preocupar com uma reparação histórica ou com o reconhecimento da existência de determinado grupo”. Já as cotas raciais possuem motivação do "reconhecimento, além de outras, como a promoção da diversidade no corpo estudantil, a projeção de negros em um espaço primordialmente ocupado por brancos e a mudança no estereótipo da pessoa negra”. (GUERRINI, 2010, p. 30)

Uma terceira via entre as políticas públicas, presente no Sistema Internacional de proteção dos Direitos Humanos, está a tutela processual dos direitos, difundida no sentido de estimular o direito de ação com força de mover a máquina jurisdicional do Estado para dar uma resposta de direito quanto ao gênero, no caso de ser ele violado. Na esfera internacional não há um tribunal próprio para o gênero, apesar de a ONU ter instituído braços especializados no fortalecimento da política de equiparação de gênero, tal como a ONU Mulher.

5 Para uma distinção entre o sistema de cotas e o sistema de metas cf. Dubugras (2013).

6 Para uma análise sobre as cotas raciais cf. Rozas (2009). 


\section{Considerações finais}

Com base no exposto, concluímos que a mulher, para ser livre e ter sua dignidade humana respeitada em sua integralidade, deve ter preservada sua independência econômica, social e emocional. Para isso, é necessário que seja propagada uma cultura de equanimidade entre os sexos, inclusive frente às oportunidades educacionais e profissionais.

As Organizações Internacionais têm papel relevante nesse processo, com o estabelecimento de consensos em torno de metas a serem alcançadas, tal como presente na Agenda 2030 da ONU. Os principais mecanismos de promoção da igualdade de gênero e empoderamento da mulher da podem ser aglutinados em três principais grupos, segundo sua natureza: a implantação de políticas públicas por normatização que estruturem um nível de equivalência ou compensação entre gêneros; a promoção de ações afirmativas em prol da mulher; e a tutela processual da causa feminina no âmbito nacional e internacional.

Dentre as alternativas, cabe aos Estados Nacionais avaliarem e aplicarem os mecanismos mais eficazes e capazes de dialogar com a realidade histórica, social, econômica e cultural de cada nação. A medição do impacto da política pública fica a cargo de cada país, que de tempos em tempos, submete os dados aos Organismos Internacionais, que os aglutinam e interpretam, a fim de se orientar na arquitetura de novos passos a serem dados diante de cada tema. O empoderamento da mulher, por sua vez, necessita ser incentivado dado o deficit histórico. Apesar da participação da mulher estar sendo incentivada e se encontrar em ascensão, tanto no ambiente público quanto no ambiente privado, ela ainda se estabelece de forma muito lenta.

No ambiente privado, apesar de quase metade dos quadros serem compostos por mulheres, a maioria delas não ocupa cargo de gestão ou recebem salários menores do que os dos homens quando realizam a mesma função. E, apesar da participação da mulher ser ascendente no mercado de trabalho, somente $37 \%$ dos cargos de gestão são exercidos por elas em grandes empresas. A participação da mulher no ensino universitário e na pesquisa científica também é considerada baixa, bem como sua participação política na esfera nacional. Essa pequena contribuição em cargos 
de evidência é atribuída à "jornada dupla” que, culturalmente, a mulher absorve frente à família e filhos.

$\mathrm{Na}$ esfera internacional, as carreiras diplomáticas que lentamente vem "feminilizando" seus quadros, como Brasil, EUA, França e Reino Unido (compostos em média de cerca de 10-20\% de mulheres), não registram medidas afirmativas como políticas de incentivo, apenas dão tratamento igualitário à candidatura de ambos os sexos.

No âmbito das Organizações Internacionais, a participação da mulher também deixa a desejar, não sendo registrado nenhum outro incentivo à composição de seus quadros por mulheres, senão a oportunidade de concorrer a vagas, nas mesmas condições dos homens. Porém, se essas instituições fomentam, como vimos, políticas de igualdade de gênero orientando globalmente as ações locais e regionais, nada mais fortalecedor do que contar com mais representatividade feminina nos seus quadros. Ter uma participação feminina mais exponencial, promovida por meio de uma medida afirmativa mais contundente, aumentaria estrategicamente a propagação e a efetividade das medidas, principalmente, pelo empoderamento oferecido à elas, na defesa de suas próprias demandas.

\section{Referências}

ALMEIDA, C. Mulheres estão em apenas 37\% dos cargos de chefia nas empresas. O Globo, Rio de Janeiro, 05 mar. 2017. Disponível em: <https:// oglobo.globo.com/economia/mulheres-estao-em-apenas-37-dos-cargosde-chefia-nas-empresas-21013908 >. Acesso em: 24 mar. 2018.

BARBUGIANI, L. H. S. Igualdade de gênero: o redimensionamento da concepção da igualdade material no âmbito laboral. 2012. 190 p. Dissertação (Mestrado) - Faculdade de Direito, Universidade de São Paulo, São Paulo, 2012.

BEAUVOIR, S. O segundo sexo. Rio de Janeiro: Nova Fronteira, 2016.

BELMONTE, R. L. C. Quotas para mulheres em conselhos de administração de empresas, à luz da teoria feminista do direito. 2014. $180 \mathrm{p}$. Tese (Doutorado) - Faculdade de Direito, Universidade de São Paulo, São Paulo, 2014 . 
BRASIL. Tribunal Superior Eleitoral. Estatísticas eleitorais. Eleições anteriores. Disponível em: < http://www.tse.jus.br/eleicoes/estatisticas/ eleicoes/eleicoes-anteriores/estatisticas-eleitorais-anos-anteriores $>$. 2016. Acesso em: 23 mar. 2018.

BRASIL. Ministério das Relações Exteriores. Mulheres na diplomacia brasileira. Disponível em: < http://www.itamaraty.gov.br/pt-BR/planonacional-de-acao-sobre-mulheres-paz-e-seguranca/14063-as-mulheresna-diplomacia-brasileira>. Acesso em: 27 mar. 2018.

DUBUGRAS, R. M. V. As medidas de ação afirmativa nas relações de trabalho: por um sistema de metas. 2013. Tese (Doutorado em Direito do Trabalho) - Faculdade de Direito, Universidade de São Paulo, São Paulo, 2013.211 p.

FRIAÇA, G. Mulheres diplomatas no Itamaraty (1918-2011): uma análise de trajetórias, vitórias e desafios. Brasília, DF: Funag, 2018.

GUERRINI, E. W. Ações afirmativas para negros nas universidades públicas brasileiras: o caso do tribunal de justiça do Rio de Janeiro (2001-2008). 2010. 149 p. Dissertação (Mestrado em Direitos Humanos) - Faculdade de Direito, Universidade de São Paulo, São Paulo, 2010.149 p.

INTER-PARLIAMENTY UNION; UNWOMEN. Women in Politics Map. Geneva; New York, 2017. Disponível em: <https://www.ipu.org/news/ press-releases/2017-03/new-ipu-and-un-women-map-shows-womensrepresentation-in-politics-stagnates> . Acesso em: 24 mar. 2018.

INTER-PARLIAMENTY UNION. Women in National Parliaments. 2018. Disponível em: <http://archive.ipu.org/wmn-e/world.htm> . Acesso em: 24 mar. 2018.

LEWANDOWSKI, Min. Ricardo. Voto do Relator. Decisão do Supremo Tribunal Federal sobre a Constitucionalidade das Cotas Raciais no Ensino Superior:ADPF186. Disponível em: $<$ http://www.stf.jus.br/ PORTAL/cms/verNoticiaDetalhe.asp?idConteudo $=205890>$.

LIMA, F. G. de S. Igualdade e inclusão: a reserva de vagas para pessoas com deficiência no serviço público. 2014. 259 p. Tese (Doutorado em Direito) - Faculdade de Direito da Universidade de São Paulo, São Paulo, 2014. MADUGRA, S. Pessoas com deficiência e direitos humanos: ótica da diferença e ações afirmativas. São Paulo: Saraiva, 2013. 
MAGALHÃES, J. C. O mundo como empresa global: aspectos da ordem internacional. São Paulo: Gruá, 2016.

NABESHIMA, Y. K. A discriminação da mulher no mercado de trabalho: estudo comparado da legislação do Brasil e do Japão. 2014. 260 f. Dissertação (Mestrado) - Faculdade de Direito, Universidade de São Paulo, São Paulo, 2014. 189 p.

NAÇÕES UNIDAS. Agenda 2030 - Desenvolvimento Sustentável. Disponível em:<https://nacoesunidas.org/pos2015/agenda2030/>. Acesso em: 20 mar. 2018.

NAÇÕES UNIDAS. Por um planeta 50-50 em 2030: mulheres e meninas na Ciência e Tecnologia. Disponível em: <http://www.onumulheres.org.br/ noticias/onu-mulheres-defende-investimentos-publicos-e-privadosem-igualdade-de-genero-para-aumentar-participacao-de-meninas-emulheres-em-ciencia-e-tecnologia/>. Acesso em: 20 mar. 2018

ORGANIZAÇÃO INTERNACIONAL DO TRABALHO. Women in labour markets: measuring progress and identifying challenges. Genebra, 2010. Available on: $<$ http://www.ilo.org/wcmsp5/groups/public/---ed_emp/--emp_elm/---trends/documents/publication/wcms_123835.pdf>. Access on: 20 mar. 2018.

ORGANIZAÇÃO INTERNACIONAL DO TRABALHO. Women at work, Trends 2016. Disponível em: <http://www.ilo.org/wcmsp5/groups/ public/---dgreports/---dcomm/---publ/documents/publication/ wcms_457317.pdf>. Acesso em: 28 mar. 2018.

ORGANIZAÇÃO INTERNACIONAL DO TRABALHO. Perspectivas Sociales y del Empleo em el Mundo: Avance global sobre las tendências del empleo feminino, 2018. Disponível em: < https://www.ilo.org/global/ research/global-reports/weso/trends-for-women2018/WCMS_619603/ lang--es/index.htm>. Acesso em: 21 mar. 2018.

PENIDO, L. de O. (Coord.). A igualdade de gênero nas relações de trabalho. Brasília: Escola Superior do Ministério Público da União, 2006.

RALWS, J. Uma teoria da justiça. Tradução: Almiro Pisetta, Lenita MR Esteves. São Paulo: Martins Fontes, 2000. 
RAMOS, L. de O. Os tribunais eleitorais e a desigualdade de gênero no parlamento: ampliando ou reduzindo a representação de mulheres na política? 2015. 187 p. Tese (Doutorado) - Faculdade de Direito, Universidade de São Paulo, São Paulo, 2015.

RÉPUBLIQUE FRANÇAISE. France Diplomatie. Le femmes dans la diplomatie: un peu d'historie. 2018. Disponível em: <https://www. diplomatie.gouv.fr/fr/le-ministere-et-son-reseau/parite-au-meae/article/ les-femmes-dans-la-diplomatie-un-peu-d-histoire> . Acesso em: 27 mar. 2018.

ROZAS, L. B. Cotas para negros nas universidades públicas e a sua inserção na realidade jurídica brasileira: por uma nova compreensão epistemológica do princípio constitucional da igualdade. 2009. $107 \mathrm{f}$. Dissertação (Mestrado) - Faculdade de Direito, Universidade de São Paulo, São Paulo, 2009.

SEVERO, T. L. M. A aplicação da categoria de gênero para a qualificação da condição jurídica da mulher refugiada. 2014. 202 p. Tese (Doutorado) Faculdade de Direito, Universidade de São Paulo, São Paulo, 2014. SIQUEIRA, D. P.; SILVA, N. T. C. Minorias \& grupos vulneráveis: reflexões para uma tutela inclusiva. Birigui: Boreal, 2013. 
8

\section{A VIOLÊNCIA SEXUAL}

CONTRA A MULHER EM

SITUAÇÃO DE CONFLITO

ARMADO

Adriana Sader Tescari

1 As ideias apresentadas neste capítulo são de responsabilidade da autora e não refletem necessariamente as posições do Ministério das Relações Exteriores. 
Em situação de conflito armado, além dos efeitos das hostilidades e de serem vítimas da violência que atinge a todos indistintamente, as mulheres enfrentam um tipo de agressão diretamente relacionada a seu gênero. A violência de natureza sexual tem sido amplamente praticada, inclusive como estratégia deliberada de guerra, na forma de estupro, escravidão e mutilação sexuais, bem como gravidez, esterilização, aborto e prostituição forçados. ${ }^{2}$

As mulheres refugiadas e as deslocadas internas são particularmente vulneráveis à violência, em especial a de natureza sexual, que ocorre durante o deslocamento, nos campos de refugiados e no momento da repatriação. Há relatos de estupros e mutilações sexuais nesse contexto por membros de grupos armados, pela polícia local e mesmo por outros refugiados.

O reconhecimento dessa realidade resultou na adoção, pelo Comitê Internacional da Cruz Vermelha, de política de presunção da ocorrência de violência sexual, mesmo na ausência de alegações, de forma a estar preparado para prover resposta humanitária adequada às vítimas. Sabese que a ocorrência deste tipo de agressão é subnotificada e que números exatos são de difícil cálculo em razão do medo de represálias e da vergonha associada à violação dessa natureza.

As consequências que a violência sexual acarreta são de longo prazo, não somente para as vítimas, mas para todo o grupo social a que pertencem. Do ponto de vista psicológico, seus efeitos incluem a desordem de estresse pós-traumático, ansiedade e depressão, que em parte dos casos leva ao suicídio. No que tange à integridade física, a gravidade dos ferimentos, muitas vezes resultado de múltiplas violações, com frequência provoca danos permanentes ou a morte da vítima. Em geral, o estupro é acompanhado de espancamentos, mutilações e outras agressões.

Porcentagem expressiva de mulheres é contaminada com doenças sexualmente transmissíveis, como o HIV/Aids. O aumento de casos da doença em razão da violência foi reconhecido pelo Conselho de

2 Para mais sobre essas definições e seu tratamento no ordenamento jurídico internacional ver Tescari (2005). 
Segurança das Nações Unidas por meio da Resolução 1308 (2000) ${ }^{3}$ e pelo Secretário-Geral da Organização em seu relatório sobre crianças em conflitos armados. ${ }^{4}$

Quantidades significativas de vítimas engravidam como resultado de estupros, tanto como consequência fortuita da violência sexual, quanto como estratégia em conflitos como registrado em Ruanda, antiga Iugoslávia, Bangladesh, Libéria e Uganda. (REHN; SIRLEAF, 2002) Parte destas mulheres morre posteriormente devido a tentativas de aborto, pois a ilegalidade desta prática na maioria das legislações locais e o desejo de esconder o ocorrido fazem com que sejam obrigadas a buscar vias clandestinas e meios perigosos. As que não abortam costumam ter problemas físicos decorrentes da violência que dificultam o parto. As agressões sexuais são também causa de infertilidade, o que afeta o grupo social por impedir que estas mulheres tenham filhos pertencentes a sua etnia.

O problema é agravado pela rejeição da comunidade às crianças nascidas da violência, seja por considerá-las parte do grupo inimigo, seja por terem sido concebidas em desacordo com normas culturais e religiosas. Muitas crianças carecem, ainda, de reconhecimento legal e administrativo, o que pode provocar apatridia.

Um dos efeitos mais comuns de violações como o estupro é o estigma que as mulheres enfrentam quando sobrevivem à violência. Frequentemente, são relegadas ao ostracismo em suas comunidades por serem consideradas impuras ou por serem acusadas de cumplicidade com o inimigo. Suas famílias, principalmente os cônjuges, tendem a rejeitá-las. A violência sexual é traumática para qualquer vítima, mas seus efeitos são ainda mais graves em sociedades patriarcais tradicionais, nas quais a castidade das mulheres reflete a honra da família, e a vítima de estupro passa a ser considerada "imprópria" para o casamento e, às vezes, até passível de punição. No plano social, enfrenta-se, ademais do estigma,

3 UNITED NATIONS. Doc. S/RES/1308 (17 jul. 2000).

4 UNITED NATIONS. Report of the Secretary-General to the Security Council on Children in Armed Conflict pursuant Security Council Resolution 1261 (1999). Doc. A/55/163-S/2000/712. parágrafo 3. 
o sentimento de culpa dos familiares pela incapacidade de protegê-las da agressão.

As mulheres sofrem, ademais, com as barreiras enfrentadas para obter atendimento médico. A distância do local onde se encontram - que resulta em riscos adicionais de segurança e custos de transporte -, o próprio custo de eventual tratamento, e o desejo/necessidade de omitir a violência sofrida em razão de sentimentos de culpa e vergonha, medo de retaliação ou tabus sociais são obstáculos de difícil superação.

A esses entraves para atendimento médico e eventual denúncia soma-se, ademais do medo do estigma, o sofrimento causado quando os responsáveis pela assistência não estão adequadamente treinados para o atendimento psicológico de violência de natureza sexual e para a necessidade de mecanismos de garantia de confidencialidade. Organizações não governamentais, como a Cruz Vermelha Internacional e a Human Rights Watch, alertaram para o fato de os serviços médicos serem geralmente prestados por homens, o que dificulta o acesso das vítimas de estupro, uma vez que muitas se recusam a relatar a violência sofrida para pessoas do sexo masculino. Enfrenta-se a pouca ou inexistente experiência destes médicos em tratar casos de violência sexual e a falta de equipamentos adequados. (HUMAN RIGHTS WATCH, 1996) Ademais, com frequência, as organizações humanitárias concentram-se no atendimento das necessidades prementes de alimento, água e/ou abrigo, ou relutam em se envolver na questão da violência sexual em razão de sua natureza sensível e pelo risco de suas ações serem percebidas como interferência em costumes locais ou crenças religiosas.

Diversas iniciativas têm sido adotadas com o objetivo de melhorar o atendimento de casos de violência sexual. Em junho de 2014, por exemplo, a conferência "Global Summit to End Sexual Violence in Conflict" reuniu cerca de 1.700 pessoas e delegados de 123 países. Em dezembro de 2015, na $32^{\text {a }}$ Conferência Internacional da Cruz Vermelha e do Crescente Vermelho, adotou-se resolução para ação conjunta na prevenção e resposta à violência sexual e de gênero. Diretrizes e treinamento para os atores envolvidos sobre como tratar o tema e como melhor coordenar a assistência têm sido desenvolvidos. As organizações de defesa dos Direitos 
Humanos e dos direitos da mulher vêm defendendo, inclusive, o aumento da participação feminina em forças de paz e em comissões de investigação com o objetivo de conseguir melhores resultados.

\section{A violência sexual e o direito internacional}

A despeito de sua ampla ocorrência nos mais diversos conflitos, no passado e no presente, a violência sexual é proibida pelo Direito Internacional, tanto implícita quanto explicitamente, seja pelo Direito Internacional Humanitário, aplicável em situação de conflito armado, seja, a todo tempo, pelos Direitos Humanos. Grandes avanços obtidos especialmente nas últimas duas décadas resultaram em arcabouço jurídico, doutrinário e jurisprudencial que, mesmo imperfeito, pode ser considerado adequado e não permite qualquer dúvida acerca das condutas proibidas e que devem ser combatidas.

As normas de Direito Internacional Humanitário, de Direitos Humanos e de proteção aos refugiados complementam-se e formam estrutura jurídica, ainda que nem sempre específica, que poderia ter sido utilizada no passado para proteger as mulheres em situação de conflito armado e coibir a violência sexual. A maior parte desses instrumentos internacionais não especifica, entretanto, proibições concernentes a violações como a maternidade forçada ou o estupro com a finalidade genocida, o que tornou necessárias a interpretação das disposições existentes e a busca de fundamento jurídico para a condenação de indivíduos por estes crimes.

No início do desenvolvimento do Direito Internacional Humanitário, regido essencialmente nos dias atuais pelas quatro Convenções de Genebra de 1949 e seus dois Protocolos Adicionais de 1977, as mulheres possuíam a mesma proteção garantida aos homens em situação de conflito armado. Se fossem feridas, estavam protegidas pelas previsões da Convenção de Genebra de 1864. Se fossem prisioneiras de guerra, a elas se aplicavam os Regulamentos Anexos às Convenções de Haia de 1899 e 1907 concernentes às Leis e Usos da Guerra Terrestre. Nenhuma norma, entretanto, conferia proteção como parte da população civil, salvo sob a perspectiva de ocupação de um território pelo exército inimigo. 
Ao fim da Primeira Guerra Mundial (1914-1918), reconheceu-se a necessidade de adaptar a Convenção de 1864 às mudanças que foram observadas, entre as quais a participação de número relativamente grande de mulheres. (KRILL, 1985) O instrumento foi revisto, dando-lhe sua forma atual, e as mulheres passaram a receber especial proteção.

Na Segunda Guerra Mundial (1939-1945), a participação de mulheres no conflito, mesmo que não no combate direto, foi ainda maior do que na Primeira Guerra, ${ }^{5}$ bem como o número de vítimas civis. Durante os julgamentos de Nuremberg, as inadequações da estrutura de proteção existente, como a ausência de previsões sobre proteção à população civil durante e após ocupações militares, tornaram-se evidentes. Em 1949, foram elaboradas, a partir dos instrumentos existentes, as quatro Convenções de Genebra. A Terceira Convenção, relativa ao tratamento de prisioneiros de guerra, e a Quarta Convenção, referente à proteção de civis em tempos de guerra, contiveram cerca de trinta artigos de especial relevância para as mulheres.

As Convenções de Genebra e os Protocolos Adicionais ${ }^{6}$ protegem atualmente as mulheres como parte da população civil. Em um conflito armado internacional, as mulheres estão entre aqueles protegidos pela Quarta Convenção de Genebra relativa à Proteção dos Civis em Tempo de Guerra e, no caso de um conflito armado não-internacional, pelas disposições do artigo $3^{\circ}$ comum às quatro Convenções e do Protocolo II. São protegidas pelas previsões gerais que garantem a todos os civis o respeito à vida e à integridade física e moral, em especial contra o homicídio sob todas as formas, as mutilações, os tratamentos cruéis, a tortura, a tomada de reféns e as ofensas à dignidade.

5 A participação de mulheres em situações de conflito é registrada no passado, em especial como enfermeiras, mas foi considerada uma exceção até o século XX. A partir da Primeira Guerra Mundial, as mulheres passaram a participar das hostilidades sistematicamente. Para mais sobre o assunto, ver Krill (1985).

6 Nos anos seguintes à Segunda Guerra Mundial, ante a comprovação do aumento da proporção de civis vítimas dos conflitos, sobretudo em razão de novos métodos de combate e de diferentes tipos de conflitos que tornaram difícil a distinção entre combatentes e civis, tornou-se necessária a elaboração de instrumentos suplementares de proteção. Em 1977, foram adotados os Protocolos Adicionais às Convenções de 1949. 
Além dessas garantias conferidas a todos os civis, às mulheres é concedida proteção especial que visa principalmente às crianças e a seu papel como genitora. Existem previsões, ademais, que se relacionam a atos de agressão sexual, como as do artigo 27 da Quarta Convenção,7 que teve por base os relatos acerca de cometimento de agressões contra mulheres e crianças durante a Segunda Guerra Mundial (INTERNATIONAL COMMITTEE OF THE RED CROSS, 1985), dos $\operatorname{artigos} 75^{8}$ e $76^{9}$ do Protocolo I, e do artigo $4^{\circ}$ do Protocolo II. ${ }^{10}$

As previsões da Convenção de Genebra são, contudo, criticadas, em razão de o foco da proteção ser a violação da honra da mulher, no sentido de qualidade moral associada à dignidade. O comentário do Comitê Internacional da Cruz Vermelha (1985, p. 205) sobre as convenções explica o ataque à honra como "forçar uma mulher a cometer atos imorais por meio de violência ou ameaças”. Este enfoque é problemático por não reconhecer que a violência sexual é uma agressão à integridade física e psicológica da mulher, bem como por relacionar a gravidade da agressão a critérios subjetivos referentes ao comportamento da vítima, uma vez que

7 Art. 27. Protected persons are entitled, in all circumstances, to respect for their persons, their honour, their family rights, their religious convictions and practices, and their manners and customs. They shall at all times be humanely treated, and shall be protected especially against all acts of violence or threats thereof and against insults and public curiosity. Women shall be especially protected against any attack on their honour, in particular against rape, enforced prostitution, or any form of indecent assault.

8 Art 75. Fundamental guarantees

2. The following acts are and shall remain prohibited at any time and in any place whatsoever, whether committed by civilian or by military agents: (b) outrages upon personal dignity, in particular humiliating and degrading treatment, enforced prostitution and any form of indecent assault;

9 Art 76. Protection of women

1. Women shall be the object of special respect and shall be protected in particular against rape, forced prostitution and any other form of indecent assault.

10 Art. $4^{\circ}$. Fundamental guarantees

2. Without prejudice to the generality of the foregoing, the following acts against the persons referred to in paragraph 1 are and shall remain prohibited at any time and in any place whatsoever: (a) violence to the life, health and physical or mental well-being of persons, in particular murder as well as cruel treatment such as torture, mutilation or any form of corporal punishment; (e) outrages upon personal dignity, in particular humiliating and degrading treatment, rape, enforced prostitution and any form or indecent assault; ( $f$ ) slavery and the slave trade in all their forms. 
critérios vinculados à moralidade podem ensejar relação com conceitos como castidade, pudor, decência e virgindade.

Ao ser a honra o interesse protegido, a violação passa a ser definida em seu contexto social com a consequência de acentuar-se a percepção da mulher vítima de violência sexual como impura e indigna, agravandose as consequências psicológicas e sociais da agressão e dificultando-se o processo de investigação. Apresentar a violência sexual como uma agressão à honra resulta também em seu tratamento como ofensa menor, já que os crimes contra a vida ou a integridade física são considerados mais importantes do que aqueles relativos aos costumes.

Vale ressaltar que, ao lado da proibição específica ao estupro, à prostituição forçada e a qualquer forma de atentado ao pudor, qualificadas como ataques à dignidade pessoal, a violência de caráter sexual contra a mulher pode ser considerada proibida pelas previsões quanto a mutilações e à escravidão, proibições abrangentes que incluem mutilações de cunho sexual e escravidão sexual (PAPACONSTANTINOU, 1998), bem como quanto à tortura.

Conforme bem estabelecido pelo Estatuto de Roma, que constituiu o Tribunal Penal Internacional, e pela jurisprudência, a violência sexual pode ser enquadrada como crime contra a humanidade e como crime de guerra. Pode, igualmente, ser considerada como ato para o cometimento de genocídio. ${ }^{11}$

Atos de agressão sexual - como o estupro, a gravidez forçada e a mutilação - quando utilizados com o propósito de destruir, no todo ou em parte, um determinado grupo nacional, étnico, racial ou religioso, podem ser enquadrados em três dos cinco atos listados no Estatuto de Roma como meios para o cometimento de genocídio. Podem ser considerados como "ofensa grave à integridade física ou mental de membros do grupo”, pela incontestável possibilidade de danos físicos e/ou mentais; como

11 Conforme a definição do crime prevista na Convenção sobre a Prevenção e a Repressão do Crime de Genocídio, em vigor desde 1951. Após a Segunda Guerra Mundial, a Assembleia Geral das Nações Unidas adotou, em 1946, a Resolução 96 (I), que utilizou o termo "genocídio" e o reconheceu como crime internacional. Dois anos depois, a AGNU aprovou a Convenção. Esta definição foi posteriormente adotada pelos estatutos dos Tribunais para a antiga lugoslávia e para Ruanda e pelo Estatuto de Roma. 
"sujeição intencional do grupo a condições de vida com vista a provocar a sua destruição física, total ou parcial”, uma vez que pode causar deslocamentos forçados, impossibilidade de cultivo dos campos em sociedades onde esta função é desempenhada pelas mulheres, desestruturação social, entre outras consequências que podem resultar em destruição do grupo; ${ }^{12}$ e como "imposição de medidas destinadas a impedir nascimentos no seio do grupo". O estupro e a mutilação sexual resultam comumente em infertilidade. Além disso, em determinadas comunidades, o estupro torna a mulher imprópria para a maternidade por torná-la "impura". A gravidez e a maternidade forçadas ${ }^{13}$ podem igualmente ser enquadradas na definição em comunidades patrilineares, nas quais a criança é considerada como pertencente ao grupo étnico ou racial ao qual pertence o pai biológico.

Observe-se que a proteção no caso do genocídio não está primordialmente relacionada ao gênero uma vez que o propósito da agressão não é o de destruir o gênero feminino, mas o grupo étnico, nacional, racial ou religioso do qual estas mulheres fazem parte. O foco desta violência é a identidade como povo, por vezes por meio das mulheres. Há, entretanto, violência, de cunho sexual, que atinge a vítima por ser ela pertencente ao gênero feminino ${ }^{14}$ e que deve ter sua gravidade reconhecida mesmo que não se enquadre na definição de genocídio e não tenha consequências de cunho sociocultural. No mesmo sentido devem ser compreendidas a gravidez forçada e a maternidade forçada, que são não apenas atos constitutivos de genocídio, mas formas de violência física contra a mulher e

12 Esta posição é defendida por organizações não governamentais, como a Human Rights Watch.

13 O Estatuto de Roma define "gravidez forçada" como "a privação ilegal de liberdade de uma mulher que foi engravidada à força, com o propósito de alterar a composição étnica de uma população ou de cometer outras violações graves do direito internacional”. De acordo coma doutrina, o melhor termo para descrever essa conduta seria “maternidade forçada”, uma vez que "gravidez forçada" seria engravidar uma mulher à força, mesmo que não haja privação posterior de liberdade.

14 Esta afirmação é correta mesmo em se tratando de estupros cometidos contra homens porque neste caso a humilhação sofrida pelo homem está relacionada com uma percepção de que ser vítima deste tipo de violação reduz o homem à condição de mulher. Assim, o estupro, seja perpetrado contra mulher ou contra homem, é um crime de gênero. Esta visão é compartilhada por Copelon (1994, p. 246). 
contra o seu direito de autodeterminação reprodutiva (COPELON, 1994), direito este garantido pela Plataforma de Ação de Pequim..$^{15}$

As mulheres têm sido vítimas de agressão sexual também como forma de tortura, violação condenada tanto como crime de guerra, quanto como crime contra a humanidade. A violência sexual tem sido utilizada tanto para coagi-las, quanto como forma de atingir seus familiares, como meio para a obtenção de informações da vítima ou de seus parentes, bem como forma de punir, intimidar, discriminar, destruir a personalidade da vítima ou diminuir suas capacidades pessoais.

O reconhecimento oficial da violência sexual contra a mulher como tortura data, entretanto, apenas da década de 1990. Em 1992, o então Relator Especial da Comissão de Direitos Humanos das Nações Unidas sobre a Tortura definiu claramente o estupro como uma forma de tortura. Este entendimento foi contemplado também pela Corte Interamericana de Direitos Humanos, em 1996, no caso Mejia versus Peru, ${ }^{16}$ e pela Corte Europeia de Direitos Humanos no caso Aydin versus Turquia, em 1997. ${ }^{17}$ A Comissão Interamericana de Direitos Humanos reconheceu ser o estupro uma forma de tortura em seu Relatório sobre a Situação dos Direitos Humanos no Haiti. ${ }^{18}$

A falta de referência à agressão sexual como uma forma de tortura no Estatuto do Tribunal para a antiga Iugoslávia representou um retrocesso neste entendimento. A falha foi sanada pelos indiciamentos e pelas decisões desse Tribunal e do Tribunal para Ruanda.

15 Plataforma de Ação de Pequim, parágrafos 95 e 96.

16 Fernando and Raquel Mejia v. Peru (Decisão de 1 de março de 1996), Report No. 5/96, case no 10.970, in Annual Report of the Inter-American Commission on Human Rights, 1996, OEA/ Ser.L/V/II.91, p. 182-188.

17 Aydin v. Turkey, Julgamento em 25 de setembro de 1997, Corte Europeia de Direitos Humanos, Reports of Judgments and Decisions, 1997-VI, parágrafos. 62-88.

18 Inter-Am CHR 43, OEA/Ser.L./V.II.88, doc 10 (1995), p. 43. 


\section{Evolução do tratamento da violência sexual}

Em toda a história da qual há registros, as mulheres têm sido vítimas de violência sexual. A importância da mulher como procriadora foi o primeiro motivador de raptos e estupros, que tinham por finalidade aumentar o número de mulheres e da população em uma comunidade em detrimento de outra. ${ }^{19}$ (CLASTRES, 1980; LÉVI-STRAUSS, 1976) Nos conflitos, as mulheres eram consideradas parte do espólio e os vencedores, por meio do estupro, consagravam sua vitória e atingiam seus inimigos. (BROWNMILLER, 1975; CHINKIN, 1994) Ainda hoje, este tipo de agressão é praticado como expressão de poder e dominação e, inclusive, como estratégia deliberada de guerra. Ainda que homens e meninos também o sejam, as mulheres e meninas são especialmente afetadas pela violência sexual, que é cometida por uma variedade de atores, tanto estatais quanto não-estatais.

O último século testemunhou inúmeros conflitos, e a agressão de natureza sexual esteve presente de forma ampla e sistemática. Durante as duas Guerras Mundiais, muitos foram os casos de violência sexual cometidos, não apenas como atos isolados, mas também como estratégia deliberada de imposição de medo e intimidação. Apesar de bem documentados, os relatos não receberam tratamento jurídico e político proporcional a sua gravidade.

Para citar apenas alguns exemplos, estima-se entre 20 e 100 mil o número de mulheres vítimas de estupros cometidos por soldados russos após a invasão de Berlim. Durante o primeiro mês de ocupação japonesa na China, em dezembro de 1937, 20 mil teriam sofrido estupros, seguidos de mutilações e assassinatos, no episódio conhecido como “o estupro de Nanking”. ${ }^{20}$ Este acontecimento provocou o ressurgimento da política japonesa de estabelecer prostíbulos, a qual se baseou na crença de que assim

19 Claude Lévi-Strauss associa as mulheres aos bens, de um lado escassos e, de outro, essenciais à vida do grupo. Pierre Clastres relaciona a troca de mulheres com a violência: "sabemos que uma das finalidades da guerra, afirmadas com a maior insistência por todas as sociedades primitivas, é a captura das mulheres: atacam-se os inimigos para se apoderarem de suas mulheres".

Há referências que apontam para 80 mil casos, mas o número 20 mil é mais frequente. 
haveria diminuição do número de casos de estupro, que provocavam descontentamento na população das regiões ocupadas e alta incidência de doenças sexualmente transmissíveis entre os membros do exército. Para tanto, cerca de 200 mil mulheres foram submetidas à prostituição forçada na Coréia e em outros territórios ocupados pelo Japão. ${ }^{21}$ Depoimentos de sobreviventes relatam até quarenta estupros por dia. Apenas $25 \%$ do total de mulheres submetidas a este tratamento sobreviveram à violência e a suas consequências. (PAPACONSTANTINOU, 1998, p. 488) As vítimas ficaram conhecidas como comfort women, tradução do termo japonês ianfu.

Durante os procedimentos realizados pelo Tribunal de Nuremberg, estabelecido para julgar as violações cometidas pelos principais criminosos de guerra alemães durante a Segunda Guerra Mundial, evidências de agressões sexuais perpetradas por soldados foram apresentadas, sem que, porém, houvesse menção nos julgamentos finais. Uma das explicações para a omissão é o fato de a violência sexual ter sido perpetrada por ambos os lados do conflito, o que acarretou desinteresse dos Aliados em julgar este tipo de violação. Os Aliados desejavam limitar os processos àqueles relativos a crimes não cometidos por suas tropas, ou seja, extermínio em massa e crimes contra a paz. ${ }^{22}$

Foi no Tribunal Militar Internacional para o Extremo Oriente, conhecido como Tribunal de Tóquio, estabelecido para julgar os principais criminosos de guerra japoneses, que o estupro foi qualificado pela primeira vez como crime de guerra e comandantes foram considerados responsáveis por agressões sexuais cometidas por soldados sob seu comando. Mesmo não havendo previsão específica do tipo penal "estupro" entre os crimes previstos no estatuto elaborado para basear os julgamentos, essa prática foi incluída na lista de indiciamentos, de forma secundária, como "tratamento desumano" e "desrespeito à honra e direitos da família”. Estabeleceu-se precedente para o julgamento deste tipo de agressão como crime de guerra.

21 O governo japonês reconheceu a existência de estabelecimentos no Japão, na China, nas Filipinas, na Indonésia, na então Malaya, na Tailândia, na então Burma, na então Nova Guiné, em Hong Kong, em Macao e na então Indochina francesa. 
A Allied Control Council Law $\mathrm{n}^{\circ} 10$, instrumento que estabeleceu as bases para o julgamento, pelos Aliados europeus, de criminosos de menor importância em suas respectivas zonas de ocupação na Alemanha entre 1946 e 1949, expandiu a lista de crimes contra a humanidade existente no Estatuto de Nuremberg e incluiu o estupro, ${ }^{23}$ mas não fez referência a outras formas de agressão sexual. Atos dessa natureza não foram listados como crimes de guerra, e nenhum processo foi apresentado com base neste tipo de violação. Foi estabelecido, entretanto, outro importante precedente.

Após a Segunda Guerra Mundial, e até o final do século XX, a violência sexual contra mulher permaneceu prática tolerada, pouco discutida e por vezes justificada como produto inevitável do contexto, em conflitos armados de caráter internacional, bem como em inúmeros conflitos não-internacionais. Para citar alguns exemplos, há relatos sobre a prática de violência sexual durante a Guerra do Vietnã, na qual soldados norte-americanos cometeram agressões sexuais de forma generalizada. (BROWMILLER, 1975; NIARCHOS, 1995) Na República Popular de Bangladesh, então Paquistão Oriental, entre 250 mil e 400 mil mulheres bengalesas foram violentadas por soldados do Paquistão Ocidental e cerca de 25 mil ficaram grávidas durante os noves meses da guerra pela independência em 1971. Muitas foram rejeitadas posteriormente por seus maridos e suas famílias, apesar de o governo as ter declarado heroínas em um esforço para reparar a situação. Os perpetradores da violência foram anistiados em troca da independência.

Em 1974, por meio da resolução 3318 (XXIX), a Assembleia Geral das Nações Unidas aprovou a Declaração sobre a Proteção de Mulheres e Crianças em Situação de Emergência e de Conflito Armado, que não fez referência à violência sexual, a despeito das evidências sobre estupros cometidos em Bangladesh três anos antes. A Declaração enfatizou a importância do papel da mulher na sociedade e na família como mãe, mantendo-se o conceito que embasou a proteção da mulher nas Convenções de Genebra de 1949.

Allied Control Council Law nº 10, artigo II, alínea (c). 
No ano seguinte, naguerra que se seguiuà independência da República de Moçambique, mutilações, execuções e violência sexual espalharam terror na população civil. Mulheres e crianças foram raptadas e mantidas como escravas sexuais por mais de dez anos. A maioria concebeu filhos de seus raptores.

A Convenção para a Eliminação de Todas as Formas de Discriminação contra a Mulher (CEDAW), ${ }^{24}$ adotada em 1979 pela resolução 34/180 da Assembleia Geral das Nações Unidas, a despeito de ter representado um importante avanço, não mencionou a violência nem mesmo como forma de discriminação ou como obstáculo ao igual gozo dos direitos pelas mulheres. Somente em 1992, o Comitê sobre a Eliminação da Discriminação Contra a Mulher, estabelecido com base no artigo 17 da CEDAW, elaborou a Recomendação Geral 19, que sanou essa ausência e afirmou ser a violência relacionada ao gênero uma forma de discriminação. Os conflitos armados foram apontados como uma das causas de aumento de casos de agressão sexual.

No ano seguinte, a Declaração sobre a Eliminação da Violência contra a Mulher, adotada em 1993 pela Resolução 48/104 da AGNU, reconheceu que as mulheres em situações de conflito são especialmente vulneráveis à violência e, ao definir os atos de violência, enumerou o estupro e a prostituição forçada.

A Conferência das Nações Unidas sobre Direitos Humanos (Viena, 1993) foi oportunidade para que organizações não governamentais inserissem no debate mais amplo o tema da defesa dos direitos da mulher, que até então vinham sendo tratados de maneira compartimentalizada, o que afastava a percepção de que as violações a esses direitos encontram-se abrangidas no problema da violação aos Direitos Humanos. ${ }^{25} \mathrm{~A}$ questão da violência contra a mulher e, em particular, da agressão sexual

24 A CEDAW entrou em vigor internacionalmente em 1981. O Brasil assinou em 1983 e ratificou em 1984, com reservas ao artigo 15, parágrafo $4^{\circ}$ e artigo 16 parágrafo $1^{\circ}$, alíneas a, c, g, h, que tratam da igualdade entre homens e mulheres no âmbito da família, devido a vigência do Código Civil de 1917. Estas reservas foram retiradas em 1994.

25 Diferentemente do ocorrido na Conferência das Nações Unidas sobre o Meio Ambiente, em 1992, as atividades oficiais e as paralelas ocorreram em um mesmo local, o que conferiu maior efetividade aos esforços das organizações não governamentais. 
em situação de conflito armado, foi objeto de debates já nas reuniões preparatórias. A Parte II do texto adotado pelo Comitê Preparatório referiu-se a violações maciças de Direitos Humanos perpetradas por meio de genocídio e estupros sistemáticos. Na Declaração de Viena e no Programa de Ação, os Direitos Humanos das mulheres e das meninas foram afirmados como inalienáveis, integrais e parte indivisível dos Direitos Humanos universais, ${ }^{26} \mathrm{e}$ foi manifestada a consternação ante sua violação massiva, em especial sob a forma de genocídio, "limpeza étnica” e estupro sistemático de mulheres em situações de conflito, as quais provocam êxodos em massa de refugiados e de pessoas deslocadas. ${ }^{27}$

A Declaração e a Plataforma de Ação de Pequim, resultantes da Quarta Conferência das Nações Unidas sobre os Direitos da Mulher ${ }^{28}$ (Pequim, 1995), reiteraram a inalienabilidade, integralidade e indivisibilidade dos direitos das mulheres em relação aos Direitos Humanos, ${ }^{29}$ bem como a necessidade de prevenir e de eliminar todas as formas de violência contra as mulheres..$^{30}$ A Plataforma também identificou a questão das mulheres em conflitos armados como uma das doze áreas críticas de preocupação. ${ }^{31}$ O documento reconheceu a gravidade das violações cometidas nesse contexto, citando especificamente a tortura, as violações sistemáticas, a prostituição forçada, a esterilização forçada, a gravidez forçada e o aborto forçado, ${ }^{32}$ e mencionou a utilização de tais práticas como arma de guerra. ${ }^{33}$

26 World Conference on Human Rights: Vienna Declaration and Programme of Action, 12 july 1993, UN.Doc. A/CONF. 157/23. parágrafo 18.

27 World Conference on Human Rights: Vienna Declaration and Programme of Action, 12 july 1993, UN.Doc. A/CONF. 157/23. parágrafo 28.

28 A IV Conferência Mundial sobre a Mulher insere-se no processo de aceleração da inclusão dos assuntos relativos à mulher na pauta da Organização das Nações Unidas, que se iniciou em 1975, ano em que a Assembleia Geral proclamou o Ano Internacional da Mulher. A partir de então, o tema foi incluído no programa da Organização e iniciou-se o Decênio das Nações Unidas para a Mulher.

29 Declaração de Pequim, parágrafos 9 e 14; Plataforma de Ação de Pequim, parágrafo 2.

30 Declaração de Pequim, parágrafo 29.

31 Plataforma de Ação de Pequim, parágrafo 44.

32 Plataforma de Ação de Pequim, parágrafos 11, 114 e 115.

Plataforma de Ação de Pequim, parágrafo 12. 
A Plataforma declarou ser o estupro em conflitos armados crime de guerra e, em certas circunstâncias, crime contra a humanidade e ato de genocídio. ${ }^{34}$ Condenou, igualmente, a prática de estupro como sendo causa de deslocamentos durante conflitos $\operatorname{armados}^{35} \mathrm{e}$, diante do fato de a agressão sexual ser utilizada como forma de perseguição em campanhas de terror e de intimidação, bem como meio de obrigar determinados grupos étnicos, culturais ou religiosos a abandonarem suas localidades de origem, ${ }^{36}$ recomendou que as mulheres, cuja solicitação tenha por base o temor de perseguição sob a forma de violência sexual, possam ser reconhecidas como refugiadas. ${ }^{37}$

A Convenção das Nações Unidas relativa ao Estatuto dos Refugiados, de 1951, não reconhece a perseguição baseada no gênero como motivo para a concessão de refúgio. Na tentativa de atualizar essas disposições, o Comitê Executivo do Alto Comissariado das Nações Unidas para os Refugiados (ACNUR) adotou várias conclusões com foco nas mulheres refugiadas e na perseguição baseada no gênero. Em 1992, adotou o entendimento de que atos de agressão sexual cometidos por razões de raça, religião, nacionalidade e pertencimento a determinados grupos sociais ou políticos, se tais atos forem perpetrados ou conhecidamente tolerados pelas autoridades competentes, podem ser considerados perseguição e razão para a concessão de asilo. (UNHRC, 1992, § 65) Este entendimento foi reforçado pela Conclusão $n^{0} 73$, no ano seguinte. ${ }^{38}$ Aborto forçado e esterilização forçada também foram considerados passíveis de constituírem perseguição baseada no gênero e podem garantir a condição de refugiada, apesar de esta interpretação não ser ainda comum entre os países.

O reconhecimento das necessidades específicas enfrentadas pelas mulheres refugiadas havia levado o ACNUR a elaborar, em 1991, documento específico de orientação (Guidelines on the Protection of Refugee Women),

34 Plataforma de Ação de Pequim, parágrafo 145, alínea (d).

35 Plataforma de Ação de Pequim, parágrafos 131 e 133.

36 Plataforma de Ação de Pequim, parágrafo 136.

37 Plataforma de Ação de Pequim, parágrafo $147 \mathrm{H}$.

38 UNHCR. Executive Committee Conclusion nº 73 (XLIV) (1993) on Refugee Protection and Sexual Violence, paragráfo (c) e (j). 
que faz referência à agressão sexual tanto como causa do refúgio, quanto como problema presente em campos de refugiados. (UNHRC, 1991, § 71) A gravidade do problema foi reconhecida igualmente pela Relatora Especial sobre a Violência contra a Mulher da Comissão de Direitos Humanos das Nações Unidas. ${ }^{39}$ Em 1995, o ACNUR publicou Sexual Violence against Refugees: Guidelines on Prevention and Response, com o objetivo de orientar sobre a questão. (UNHRC, 1995)

No plano regional, a Convenção Interamericana para Prevenir, Punir e Erradicar a Violência Contra a Mulher (Convenção de Belém do Pará), ,4 adotada em 1994, determinou, em seu artigo $2^{\circ}$, que a violência contra a mulher abrange a violência sexual, bem como a física e a psicológica, e enumera atos como o estupro e a prostituição forçada.

A maior atenção conferida na década de 1990 pelos foros internacionais ao tema da violência sexual contra a mulher não se refletiu, entretanto, em modificação do quadro de ocorrência desse tipo de agressão nos conflitos naquele período.

No conflito iniciado em 1996 na República Democrática do Congo, verificou-se a prática da violência sexual por quase todas as forças participantes no conflito. (HUMAN RIGHTS WATCH, 2002) Em certos casos, estupros foram cometidos como parte de ataques à população civil, com a finalidade de aterrorizar as comunidades e obter aceitação do controle ou para punir eventuais auxílios às forças opostas. Em outros, pequenos grupos de soldados violentaram mulheres e meninas que encontraram aleatoriamente nos campos, nas ruas ou nas casas. Com frequência, os estupros foram seguidos de assassinatos ou mutilações.

Durante o conflito na República Ruandesa, em 1994, a violência sexual foi utilizada de forma ampla e sistemática por membros da milícia Hutu conhecida como Interahamwe, por outros civis e por soldados das Forças

UNITED NATIONS. Report of the Special Rapporteur on violence against women, its causes and consequences. Doc. E/CN. 4/1998/54 (26 jan. 1998).

40 Adotada por aclamação na $24^{\mathrm{a}}$ sessão da Assembleia Geral da OEA em 1994 e ratificada pelo Brasil, sem reservas, em novembro de 1995. 
Armadas Ruandesas. ${ }^{41}$ Líderes administrativos, políticos e militares, bem como os líderes da milícia, comandaram ou encorajaram atos de violência sexual com o objetivo de destruir o grupo étnico tutsi. (HUMAN RIGHTS WATCH, 1996) A propaganda que exortou os hutus a cometerem o genocídio identificou especificamente a sexualidade das mulheres tutsis como meio pelo qual o grupo étnico a que pertenciam teria controlado a comunidade hutu e, assim, transformou a agressão sexual em uma forma de atingir o grupo rival. Parte das mulheres hutus também sofreu violência sexual por terem sido consideradas simpatizantes do inimigo. Nos campos de refugiados, foi relatado que praticamente todas as mulheres foram agredidas sexualmente.

No território da antiga Iugoslávia, especialmente entre 1991 e 1993 , mulheres foram reunidas em escolas, casas e praças de esportes e estupradas repetidamente. As estimativas quanto ao número de vítimas variam entre 20 mil e 50 mil. Verificou-se a utilização do estupro como parte de uma política deliberada de terror, que objetivou forçar os muçulmanos bósnios ao deslocamento, bem como o estabelecimento de "campos de estupro”, por ambos os lados do conflito, (ASKIN, 1997, p. 275) nos quais as mulheres foram submetidas à gravidez forçada e à maternidade forçada, por meio de estupros repetidos e detenção para fins de evitar o aborto. (REHN; SIRLEAF, 2002)

Em razão dos relatos concernentes ao conflito na antiga Iugoslávia, os órgãos das Nações Unidas passaram a tratar da questão da violência sexual de forma mais direta. A Resolução 798 (1992) do Conselho de Segurança ${ }^{42}$ tratou especificamente dos relatos de detenções e estupros sistemáticos, organizados e em escala massiva ocorridos na Bósnia Herzegovina. Quatro meses depois, o Conselho reforçou a reprovação deste tipo de agressão na resolução 820 (1993) ${ }^{43}$ ao condenar todas as violações do Direito Internacional Humanitário, particularmente a prática de

\footnotetext{
41 UNITED NATIONS. Report on the Situation of Human Rights in Rwanda submitted by Mr. René Degni-Segui, Special Rapporteur of the Commission on Human Rights, under paragraph 20 of Resolution S-3/1 of 25 May 1994. E/CN.4/1996/68 (29 Jan 1996), p. 7.

UNITED NATIONS. Doc. S/RES/798 (18 dec.1992).

43

UNITED NATIONS. Doc. S/RES/820 (17 april 1993).
} 
"limpeza étnica" e a detenção e estupro de mulheres. Reafirmou, também, que os perpetradores da violência, bem como aqueles que as ordenaram, deveriam ser responsabilizados individualmente por seus atos.

O Conselho continuou a incluir o estupro entre as violações aos Direitos Humanos e ao Direito Internacional Humanitário cometidas no território da antiga Iugoslávia em resoluções posteriores sobre o conflito. ${ }^{44} \mathrm{~A}$ violência sexual foi igualmente condenada em resoluções que trataram de crianças em conflitos armados. ${ }^{45}$

A Assembleia Geral manifestou-se igualmente sobre o tema em resoluções específicas sobre o estupro e o abuso de mulheres nas áreas de conflito na antiga Iugoslávia e reconheceu ser a agressão sexual uma prática utilizada com o propósito de "limpeza étnica" e, portanto, uma forma de genocídio, bem como um crime de guerra. O Tribunal para a antiga Iugoslávia foi encorajado a dar a prioridade devida a casos relacionados a estupros na região e foi sublinhada a necessidade de estabelecer-se programa de proteção a testemunhas, a fim de proporcionar condições para a averiguação de fatos perante o Tribunal. ${ }^{46} \mathrm{Em}$ 1995, o estupro foi considerado não apenas como crime de guerra e como genocídio, mas também como crime contra a humanidade. ${ }^{47}$ Esta categorização foi reafirmada por resolução do ano seguinte. $4^{8}$

Os tribunais internacionais ad hoc estabelecidos em razão dos conflitos em Ruanda (ICTR) e na antiga Iugoslávia (ICTY) respaldaram o entendimento de que atos de violência sexual podem ser enquadrados como crime de guerra, como crime contra a humanidade e como genocídio, bem como considerados como uma forma de tortura. ${ }^{49}$ Nas decisões, foram discutidas, com base no costume e no Direito Internacional, o

44 UNITED NATIONS. Doc. S/RES/1019 (o9 nov. 1995) e Doc. S/RES/1034 (21 dez.1995).

45 UNITED NATIONS. Doc. S/RES/ 1261 (30 aug. 1999) e Doc. S/RES/ 1379 (27 april 2001).

46 UNITED NATIONS. Doc. A/RES/ 46/242 (25 aug. 1992); UNITED NATIONS. Doc. A/RES/48/143 (20 dec. 1993); UNITED NATIONS. Doc. A/RES/49/205 (23 dec. 1994).

47 UNITED NATIONS. Doc. A/RES/5O/ 192 (22 dec. 1995).

48 UNITED NATIONS. Doc. A/RES/51/115 (12 dec. 1996).

49 Para mais sobre o enquadramento como tortura, ver Tescari (2005) e ICTY, Prosecutor $v$. Zejnil Delalic and Others (Celebici case), Case No. IT-96-21. 
enquadramento de condutas de violência sexual como crimes internacionais puníveis sob seus estatutos. A nudez forçada, por exemplo, foi condenada como violência de caráter sexual passível de ser enquadrada na categoria de crime contra a humanidade, corroborando a visão de que um ato de violência não resulta unicamente de agressão física, mas também psicológica. ${ }^{\circ}$

Os tribunais trataram, igualmente, da definição de atos de agressão sexual, como o estupro, para a qual não há descrição única no Direito Internacional..$^{51}$ Mesmo que o entendimento não seja ainda consensual, a violência sexual foi considerada de forma ampla, não se limitando à invasão física do corpo humano por meio de órgãos sexuais, de forma a permitir o julgamento por atos que não envolvessem a penetração ou sequer o contato físico. Em alguns casos, não se considerou necessária a prova da existência de força física como elemento de coerção, uma vez que certas circunstâncias, como a existência de um conflito armado ou a presença militar, podem ser reputadas como elemento coercitivo por si só.

O Tribunal para Ruanda foi responsável pela primeira condenação, por uma corte internacional, de uma mulher por crimes relacionados à violência sexual. Pauline Nyiramasuhuko, Ministra para assuntos da Família e da Mulher na época do conflito em Ruanda, foi indiciada por estupro e outros crimes desta natureza em razão de sua responsabilidade por atos de seus subordinados, bem como por planejamento e instigação. Apesar de não ser a autora material da violência, Pauline foi acusada de planejar e ordenar a agressão sexual sistemática contra as mulheres tutsis durante o genocídio de 1994.

O caso Kunarac, Kovac e Vukovic ("Foca”), ${ }^{52}$ julgado pelo Tribunal para a antiga Iugoslávia e conhecido como "caso do campo de estupro", representou importante passo no tratamento da violência sexual por ter

50 ICTR, Prosecutor v. Jean-Paul Akayesu, Case No. ICTR-96-4

51 Ver casos ICTR, Prosecutor v. Jean-Paul Akayesu, Case No. ICTR-96-4; ICTY, Prosecutor v. Anto Furundzija, Case No. IT-95-17-1; ICTY, Prosecutor v. Dragoljub Kunarac adn Others, Case No. IT-96-23\&23.

52 ITCY, Prosecutorv Kunarac and Others, Case IT-96-23. Este caso foi indiciado primeiramente como Prosecutor v. Gagovic e outros. 
sido o primeiro indiciamento da história dos crimes internacionais em que o processo foi baseado unicamente em acusações dessa natureza. As mulheres foram detidas na escola da cidade, no ginásio de esportes e em algumas casas e submetidas a estupros, humilhações e tortura, bem como obrigadas a executar tarefas domésticas. Os réus foram processados por estupro, tortura, escravidão e ofensas à dignidade pessoal.

Igualmente relevante para o tratamento da violência sexual foi o estabelecimento, pelo Tribunal para a antiga Iugoslávia, da Norma de Procedimento e Evidências n. 96. Da mesma forma como costuma ocorrer em âmbito nacional, as vítimas de violência sexual em conflito armado sofrem com o procedimento probatório. Com o objetivo de facilitar o julgamento de casos dessa natureza, foram estabelecidas normas visando a minimizar os fatores inibidores de denúncias e testemunhos. A Norma n. 96 estabeleceu, entre outras regras, que a conduta sexual da vítima antes da violência não deve ser considerada. Em face das dificuldades para a obtenção de evidências (como sêmen, sangue ou outra qualquer prova material), bem como de testemunhas em alguns casos, determinou igualmente que o testemunho da vítima não necessita ser corroborado. Foram também determinados parâmetros para o tratamento de eventual alegação por parte da defesa da existência de consentimento da vítima.53

De modo a conferir maior proteção às vítimas e às testemunhas, foi considerada, no caso Tadic, ${ }^{54}$ a possibilidade de testemunho por meio de circuito fechado de televisão. A decisão estabeleceu precedente para a concessão de medidas protetoras à testemunha que facilitassem o depoimento de vítimas de violência sexual e aumentou a possibilidade de apresentação de evidências de forma eficaz. Em face da histórica omissão de evidências de agressões sexuais nos tribunais, ${ }^{55}$ esta garantia representou importante passo para o reconhecimento da ocorrência do problema e sua condenação.

\footnotetext{
53 Para mais sobre os debates relativos a Norma 96, ver Fitzgerald (1997).

54 ICTY, Prosecutorv Tadic, Case IT-94-1-T.

55 Para mais sobre a questão da ausência de evidências, ver Sellers (1998, p. 12).
} 
Em 1998, o Estatuto de Roma, convenção multilateral celebrada com o propósito de constituir um tribunal internacional, permanente e independente, complementar às jurisdições nacionais, para julgar indivíduos acusados de cometer as violações mais graves que afetam o conjunto da comunidade internacional, reconheceu atos de agressão sexual e de gênero como crimes sérios enquadrados pelo Direito Internacional.

O Estatuto prevê competência do Tribunal Penal Internacional para o julgamento de violência sexual como crime contra a humanidade e como crime de guerra. Estupro, escravidão sexual, prostituição forçada, gravidez forçada, esterilização forçada e "qualquer outra forma de violência no campo sexual de gravidade comparável”" ${ }^{6}$ são listadas entre as condutas puníveis, o que significou desenvolvimento considerável do conceito desse tipo de crime internacional, em especial pela codificação de sua punibilidade por um instrumento multilateral.

Entre as previsões do Estatuto, provocou controvérsia a expansão dos motivos de perseguição previamente aceitos para incluir a perseguição baseada no gênero como um crime contra a humanidade (alínea "h"). A inclusão seria necessária, segundo seus defensores, porque grande parte das agressões cometidas contra mulheres ocorreriam com base no gênero e não na etnia, nacionalidade ou raça. (ASKIN, 1997) Por outro lado, como o Estatuto de Roma não relaciona crime contra a humanidade com uma situação de conflito armado, a previsão poderia permitir, em tese, o julgamento de casos que se baseassem exclusivamente em discriminação contra mulheres exercida pelo próprio Estado. Para solucionar a questão, foi incluída a necessidade de a perseguição ter relação com outra conduta prevista no Estatuto para ser configurada como crime contra a humanidade.

O tratamento desse ponto evidenciou as dificuldades do tratamento da violência de gênero em relação a questões religiosas e culturais. Podese citar como outro exemplo que a Santa Sé, apoiada pela Liga dos Estados Árabes, tentou impedir não apenas a inclusão da perseguição baseada no gênero, mas igualmente da gravidez forçada nos crimes previstos pelo

56 Artigo $7^{\circ}$, parágrafo $1^{\circ}$, alínea (g), Artigo $8^{\circ}$, parágrafo $2^{\circ}$, alínea (b) (xxii) e artigo $8^{\circ}$, parágrafo $2^{\circ}$, alínea (e) (vi). 
Estatuto de Roma. ${ }^{57}$ A tentativa de excluir qualquer menção a gênero no Estatuto deveu-se ao não reconhecimento da construção social de papéis específicos e de hierarquia entre gêneros distintos, pois este reconhecimento seria inconsistente com a crença de que homens e mulheres seriam essencialmente diferentes e possuiriam direitos e funções diversos. A principal preocupação foi a possibilidade de o termo ser entendido como relacionado a orientação sexual. A definição de gênero adotada pelo Estatuto refletiu as duas visões ao fazer referência aos "sexos masculino e feminino, no contexto da sociedade"..$^{8}$

A enumeração da gravidez forçada, seja como crime contra a humanidade, seja como crime de guerra, recebeu especial oposição da Santa Sé, de países islâmicos e de grupos conservadores norte-americanos, que desejavam eliminar qualquer sugestão de que obstruir o acesso de uma mulher ao aborto poderia ser considerado crime..$^{59}$ Após tentativa da representação da Santa Sé de substituir o termo "forced pregnancy" por "forcible impregnation", proposta rejeitada por não conter todos os elementos que os defensores da presença desta violação pretendiam incluir, o impasse foi solucionado com a inserção da frase: "Esta definição não pode, de modo algum, ser interpretada como afetando as disposições de direito interno relativas à gravidez". ${ }^{60}$

Em outubro de 2000, o Conselho de Segurança adotou a resolução 1325 (2000), ${ }^{61}$ considerada um marco no tratamento do impacto para as mulheres dos conflitos armados. A resolução tratou da violência sexual ao solicitar que todas as partes envolvidas em conflitos armados tomassem medidas especiais de proteção a mulheres e crianças contra violência baseada no gênero, particularmente estupro e outras formas de abuso

57 Para mais sobre os debates, ver Copelon (2000), Hall-Martinez e Bedont (1999) e Steains (1999).

58 Artigo $7^{\circ}$, parágrafo 3.

59 A lista de países que se opuseram inicialmente ou expressaram preocupação inclui também Costa Rica, Equador, Filipinas, Irlanda, Nicarágua, Paraguai, Polônia, Rússia e Venezuela, entre outros.

60 Artigo $7^{\circ}$, parágrafo $2^{\circ}$, alínea $(f)$,

61 UNITED NATIONS. Doc. S/RES/1325(2000). 
sexual. A resolução enfatizou, ainda, a responsabilidade dos Estados de julgarem os responsáveis por estes crimes e de excluí-los, quando viável, das previsões sobre anistia.

Marco igualmente importante foi a adoção da resolução $1820(2008)^{62}$ do CSNU, na qual o Conselho reconheceu que a violência sexual tem sido utilizada como tática de guerra e pode constituir crime de guerra, crime contra a humanidade e ato constitutivo de genocídio. ${ }^{63}$ Ademais, solicitou que o Secretário-Geral submetesse relatório sobre a implementação da resolução. No ano seguinte, a resolução 1888 (2009) ${ }^{64}$ do CSNU manifestou preocupação com a falta de progresso verificada no relatório apresentado pelo SGNU e solicitou ao Secretário-Geral a nomeação de Representante Especial para Violência Sexual em Conflito. ${ }^{65}$

O Conselho seguiu manifestando-se sobre o tema ${ }^{66}$ e reconheceu o impacto da violência sexual nas comunidades em que ocorre e o prejuízo que provoca aos esforços para a paz, a segurança e a reconstrução após o fim do conflito. As resoluções sedimentaram o entendimento da comunidade internacional de que agressões dessa natureza não são consequência inevitável de um conflito, mas sim um crime que deve ser combatido e punido pelo direito nacional e internacional.

Nesse contexto, o Tribunal Especial para Serra Leoa proferiu, em 2009, decisão condenatória por crimes de estupro, escravidão sexual e casamento forçado. ${ }^{67} \mathrm{O}$ Tribunal havia sido estabelecido em 2002, por

62 UNITED NATIONS. Doc. S/RES/1820 (2008).

63 Em junho de 2015, a Assembleia Geral das Nações Unidas proclamou 19 de junho como Dia Internacional para a Eliminação da Violência Sexual em Conflito. A data foi escolhida para comemorar a adoção, na mesma data, em 2008, da resolução 1820 (2008) do CSNU. UNITED NATIONS DOC. A/RES/69/293.

64 UNITED NATIONS. Doc. S/RES/1888 (2009).

65 A Representante Especial para Violência Sexual em Conflito exerce igualmente a função de presidente da rede "UN Action against Sexual Violence in Conflict", estabelecida em $2007 \mathrm{e}$ que congrega 13 entidades do Sistema ONU com o objetivo de combater a agressão de natureza sexual.

66 UNITED NATIONS. Doc. S/ RES/ 1889 (2009), UNITED NATIONS. Doc. S/ RES/ 1960 (2010), UNITED NATIONS. Doc. S/RES/ 2106 (2013), UNITED NATIONS. Doc. S/RES/ 2122 (2013).

67 SCSL, Prosecutorv Sesay, Kallon \& Gbao, Case SCSL-04-15. Para mais sobre o tratamento dos casos no Tribunal de Serra Leoa, ver Oosterveld (2011). 
solicitação do governo daquele país às Nações Unidas por uma corte que tratasse dos crimes cometidos na guerra civil (1991-2002), durante o qual todas as partes envolvidas utilizaram de violência sexual ampla e sistemática. ${ }^{68}$ As mulheres de Serra Leoa enfrentaram a agressão sexual também na República da Guiné, onde buscaram refúgio.

O Tribunal Penal Internacional, por sua vez, reconheceu os desafios e obstáculos para a investigação e julgamento dos crimes sexuais e de gênero e incluiu a questão entre seus objetivos no Plano Estratégico 20122015. Em 2016, proferiu a primeira condenação por crimes dessa natureza, contra Jean Pierre Bemba, por violações cometidas por suas milícias em 2002 e 2003 na República Centro-Africana, entre as quais o estupro, considerado crime contra a humanidade e crime de guerra. ${ }^{69}$

$\mathrm{O}$ ano de 2016 testemunhou ainda outras importantes decisões no combate à violência sexual. A Guatemala tornou-se o primeiro país no qual uma corte nacional proferiu decisão condenatória pelo crime de escravidão sexual durante conflito armado, no chamado caso "Sepur Zarco”. De 1982 a 1988, as mulheres do grupo indígena Q’eqchi’ na vila de Sepur Zarco foram vítimas de estupros sistemáticos e escravidão. Ademais, o Tribunal Especial do Senegal sentenciou o ex-presidente do Chade (1982-1990), Hissène Habré, por crimes contra a humanidade, entre os quais estupro e escravidão sexual. As Nações Unidas e a Liga dos Estados Árabes assinaram um acordo para fortalecer a colaboração para a prevenção da violência sexual relacionada a conflitos em países árabes.

A despeito, entretanto, da presença do tema em diversas resoluções das Nações Unidas e em documentos produzidos por organizações internacionais governamentais e não governamentais, bem como o avanço representado pelas decisões acima citadas, a violência sexual contra a mulher segue presente nos conflitos mais recentes. Em seus relatórios

68 UNITED NATIONS. Report of the Special Rapporteur on violence against women, its causes and consequences. UN Doc. E/CN.4/2002/83/add.2(2002).

69 ICC, Prosecutor v. Jean-Pierre Bemba Gombo, Case ICC-01/05-01/08. 
sobre o tema referentes aos anos de $2016^{70}$ e $2017,{ }^{71}$ elaborados em atenção à resolução 2106 (2013) do CSNU,72 o Secretário-Geral das Nações Unidas listou 19 países nos quais teria ocorrido violência sexual em situação de conflito armado. São citados, entre outros, Afeganistão, República Centro Africana, Colômbia, República Democrática do Congo, Iraque, Myanmar, Sudão do Sul e Síria. O documento sublinhou que a maior presença de mulheres nas missões de monitoramento e análise teria sido responsável pela maior disponibilidade e qualidade dos dados coletados. Ressalvou, entretanto, que esses seriam apenas aqueles casos em que haveria informação confiável, obtida pelas Nações Unidas.

\section{Conclusões}

A violência de natureza sexual contra a mulher tem estado presente em conflitos armados com diferentes propósitos. Tem sido utilizada com o intuito de aterrorizar populações e provocar seu deslocamento, como meio de destruir a identidade de grupos étnicos, como forma de obter informações e intimidar, como punição e retaliação, como símbolo de dominação e até como recompensa para soldados. Sua prática tem efeitos não apenas para a vítima, mas para todo o grupo ao qual pertence, e provoca desestruturação social.

A questão, a despeito dos frequentes e reiterados casos relatados, bem como da existência de uma estrutura jurídica internacional que poderia ter sido utilizada para puni-los, foi por muito tempo negligenciada. De forma geral, relatos foram utilizados apenas com o propósito de ilustrar a crueldade do inimigo, a fim de justificar guerras e mobilizar a população. A história raramente faz referência a essas violações como algo mais do que consequências, inevitáveis ainda que indesejáveis, dos conflitos.

70 UNITED NATIONS. Report of the Secretary-General on conflict-related sexual violence. Doc. S/2017/249 (15 Apr. 2017).

71 UNITED NATIONS. Report of the Secretary-General on conflict-related sexual violence. Doc. $\mathrm{S} / 2018 / 250$ (23 Mar. 2018)

72 UNITED NATIONS. Doc. S/RES/2106 (2013). 
O tema passou a ser objeto de maior consideração apenas nas últimas décadas. A atenção despertada pelo amplo emprego da violência sexual, inclusive como estratégia de guerra, na antiga Iugoslávia e em Ruanda, na década de 1990, contribuiu para modificar a percepção desta prática como sendo uma questão privada para torná-la um problema público e político. Desde então e progressivamente, o paradigma pelo qual era considerada apenas como uma consequência inevitável da situação de conflito e tema pouco discutido transformou-se, o que se refletiu em decisões em foros e tribunais internacionais.

É fato também, entretanto, que ainda não se pode afirmar que essa mudança de paradigma tenha se refletido em cenário distinto no que toca à realidade no terreno. A violência contra a mulher em situação de conflito armado permanece prática comum e tem se revestido de novas formas, como os casamentos forçados e a utilização das mulheres como fonte de renda por grupos armados por meio de, entre outros, a extorsão de pagamento de resgate e o tráfico sexual. As mulheres seguem sendo utilizadas como "pagamento" ou "recompensa" aos combatentes.

A continuidade desta forma de violência, inclusive de maneira publica em inúmeros casos, demonstra a crença dos perpetradores na impunidade. Nesse sentido, é essencial que os responsáveis sejam efetivamente punidos. A responsabilização individual já foi há muito reconhecida como o meio mais eficaz de impedir o cometimento de infrações ao Direito Internacional, pois a responsabilização apenas estatal não sensibiliza os indivíduos e não os compele a respeitar normas.

As decisões proferidas por tribunais internacionais demonstraram a existência de disposição em julgar e condenar a agressão sexual. A aplicação das normas necessita, contudo, ser fortalecida, tanto no âmbito internacional, quanto no doméstico. A responsabilização de superiores pelo comportamento de seus subordinados representou importante fator de desestímulo por torná-los menos complacentes à conduta ilícita.

É importante que as normas relativas à violência sexual contra a mulher e a punibilidade da conduta sejam objeto de ampla divulgação, de modo a coibir sua prática. Afinal, o objetivo primordial de uma estrutura legal não deve ser punir, mas prevenir. A proibição da agressão sexual 
deve, assim, constar de códigos de conduta militares e de treinamento adequado das forças armadas, bem como implicar em sanções administrativas e criminais, de modo a que a consciência da ilegalidade de atos dessa natureza seja fator que resulte na efetiva diminuição da ocorrência desta prática nos conflitos presentes e futuros.

A punição é essencial não apenas pela gravidade em si das agressões de natureza sexual, mas também porque não condená-las da mesma forma como se condenam outras formas de combate - como o uso de certas armas - pode acarretar a opção por seu uso como estratégia deliberada por grupos armados.

É relevante, igualmente, que se observe a importância da condenação da violência de natureza sexual contra a mulher não apenas em seu componente genocida, mas também por ser um ato de violência contra o indivíduo. É necessário que haja cautela para não se perpetuar a proteção das mulheres apenas no que diz respeito a sua função sociocultural e biológica nas comunidades às quais pertencem. A agressão sexual deve ser punida independentemente de seu propósito e da escala em que ocorre.

A condenação por atos de violência sexual contra a mulher perante cortes internacionais e a previsão específica em instrumentos jurídicos como o Estatuto de Roma podem operar como modelos inspiradores também para os sistemas nacionais. A incorporação de normas relativas à proteção da mulher contra atos desta natureza não irá automaticamente modificar a estrutura geral que se baseia na discriminação e na construção social do papel da mulher na sociedade, mas encoraja os Estados a incorporarem a perspectiva em seus ordenamentos domésticos, não apenas no que diz respeito à situação de conflito armado, mas também em tempo de paz. Estes julgamentos possuem um importante papel de construtores da ordem.

As regras para o procedimento probatório adotadas pelos tribunais ad hoc têm igualmente o potencial de influenciar ordenamentos domésticos. Essas regras concederam às vítimas de violência sexual, de modo a minimizar os fatores inibidores de denúncias e testemunhos, garantias em geral ausentes nas legislações nacionais. Além de possibilitar a melhor averiguação dos casos, seu julgamento e a condenação dos perpetradores, 
representaram importante passo na modificação de uma estrutura tradicionalmente baseada em argumentos sobre a conduta da mulher e que legava às vítimas o ônus de comprovarem idoneidade moral e comportamento socialmente aceitável. Os tribunais internacionais ad hoc reconheceram a existência de concepções culturais discriminatórias em relação às mulheres e as repudiou.

Crédito deve ser dado às organizações não governamentais de defesa dos Direitos Humanos e dos direitos das mulheres, que importante papel têm desempenhado na investigação de casos de violência sexual e na divulgação da gravidade do problema. A atuação destas entidades foi fundamental para que ocorressem indiciamentos de indivíduos acusados de crimes desta natureza nos tribunais internacionais e na inserção de dispositivos específicos no Tratado de Roma.

O tratamento da violência sexual em conflitos armados requer esforço multidisciplinar que envolve áreas com a ciência política, o direito, a saúde, a psicologia e a ética militar. Atenção deve ser dada a reintegração social e econômica da mulher, e das crianças nascidas da violência, em seu meio social. Caso contrário, estarão suscetíveis à exploração e a mais violência. Líderes comunitários, religiosos e militares têm importante papel a desempenhar tanto para influenciar o comportamento dos combatentes, quanto em modificar essa realidade. A participação de mulheres nos esforços de resolução dos conflitos e na construção da paz não deve ser negligenciada. Os organismos multilaterais, os Estados e as organizações não governamentais têm para si esta tarefa.

\section{Referências}

ASKIN, K. D. War Crimes Against Women: Prosecution in International War Crimes Tribunals. Haia: Martinus Nijhoff Publishers, 1997.

BROWNMILLER, S. Against Our Will: Men, Women and Rape. New York: Simon and Shuster, 1975.

CHINKIN, C. Rape and Sexual Abuse of Women in International Law. European Journal of International Law, v. 5, n. 3, p. 326-341, 1994. 
CLASTRES, P. Guerra, religião e poder. Tradução João Afonso dos Santos. Lisboa: Edições 70, 1980.

COPELON, R. Surfacing Gender: Re-Engraving Crimes Against Women in Humanitarian Law. Hastings Women's Law Journal, v. 5, p. 243-266, 1994.

COPELON, R. Gender Crimes as War Crimes: Integrating Crimes Against Women into International Criminal Law. McGill Law Journal, v. 46, p. 217-240, nov. 2000.

FITZGERALD, K. Problems of Prosecution and Adjudication of Rape and Other Sexual Assaults under International Law. European Journal of International Law, v. 8, n. 4, p. 638-663, 1997.

HALL-MARTINEZ, K.; BEDONT, Barbara. Ending Impunity for Gender Crimes under the International Criminal Court. Brown Journal of World Affairs, v. 6, p. 65-85, 1999.

HUMAN RIGHTS WATCH. Shattered Lives: Sexual Violence during the Rwandan Genocide and its Aftermath. New York: Human Rights Watch, 1996.

HUMAN RIGHTS WATCH. The War within the War: Sexual Violence Against Women and Girls in Eastern Congo. New York: Human Rights Watch, 2002.

INTERNATIONAL COMMITTEE OF THE RED CROSS. Commentary on IV Geneva Convention Relative to the Protection of Civilian Persons in Time of War. Geneva, 1958.

KRILL, F. The Protection of Women in International Humanitarian Law. International Review of the Red Cross, Geneva, n. 249, p. 337-363, 1985.

LÉVI-STRAUSS, C. As estruturas elementares do parentesco. Tradução Mariano Ferreira. São Paulo: EdUSP, 1976.

NIARCHOS, C. Women, War and Rape: Challenges Facing the International Tribunal for the Former Yugoslavia. Human Rights Quaterly, v. 17, p. 649-690, 1995.

OOSTERVELD, V. The Gender Jurisprudence of the Special Court for Sierra Leone: Progress in the Revolutionary United Front Judments. Cornell International Law Journal, v. 44, n. 1, p. 49-74, 2011 
PAPACONSTATINOU, M. Rape as a Crime under International Humanitarian Law. Revue Hellénique de Droit International, Atenas, v. 51, n. 2, p. 477-99, 1998.

REHN, .; SIRLEAF, E. J. Women, War, Peace: The Independent Expert's Assessment on the Impact of Armed Conflict on Women and Women's Role in Peace-building. New York: United Nations Development Fund for Women, 2002.

SELLERS, P. V. Emerging Jurisprudence on Crimes of Sexual Violence. American Journal of International Law, Washington, v. 13, p. 1524-1539, 1998.

STEAINS, C. Gender Issues. In: LEE, Roy. The International Criminal Court: The Making of the Rome Statute. The Hague: Kluwer Law International, 1999. p.357-390.

TESCARI, A. S. Violência sexual contra a mulher em situação de conflito armado. Porto Alegre: Sérgio Antonio Fabris, 2005.

UNHCR. Executive Committee Conclusion $n^{\circ} 73$ (XLIV) (1993) on Refugee Protection and Sexual Violence.

UNHCR. Guidelines on the Protection of Refugee Women. Geneva, 1991.

UNHCR. Handbook on Procedures and Criteria for Determining Refugee Status. Geneva, 1992.

UNHCR. Sexual Violence against Refugees: Guidelines on Prevention and Response. Geneva, 1995.

UNITED NATIONS. Report of the Secretary-General to the Security Council on Children in Armed Conflict pursuant Security Council Resolution 1261 (1999). UN Doc. A/55/163 - S/2000/712 (1999).

UNITED NATIONS. Report of the Secretary-General on conflict-related sexual violence. Doc. S/2017/249 (15 April 2017).

UNITED NATIONS. Report of the Secretary-General on conflict-related sexual violence. Doc. S/2018/250 (23 Março 2018)

UNITED NATIONS. Report of the Special Rapporteur on violence against women, its causes and consequences. UN Doc. E/CN.4/1995/42 (1994). 
UNITED NATIONS. Report of the Special Rapporteur on violence against women, its causes and consequences. Doc. E/ CN. 4/ 1998/ 54 (26 jan. 1998). UNITED NATIONS. Report of the Special Rapporteur on violence against women, its causes and consequences. UN Doc. E/CN.4/2002/83/add.2 (2002).

UNITED NATIONS. Report on the Situation of Human Rights in Rwanda submitted by Mr. René Degni-Segui, Special Rapporteur of the Commission on Human Rights, under paragraph 20 of Resolution S-3/1 of 25 May 1994. UN Doc. E/CN.4/1996/68 (1996). 
Parte III - Gênero e Cosmopolitismo 


\section{9}

\section{A ONU MULHERES}

NA ALDEIA:

iterações democráticas e mediação cultural

\section{Denise Vitale \\ Renata Nagamine e \\ Giselle Amorim de Souza'}

1 As autoras agradecem o apoio do CNPq e da CAPES na elaboração deste capítulo. Denise Vitale é bolsista Produtividade em Pesquisa CNPq nível 2 (Processo \# 311709/2015-0), Renata Nagamine é bolsista PNPD-CAPES, Giselle Amorim é bolsista de mestrado CAPES. 


\section{Introdução}

Este capítulo aborda a atuação da ONU Mulheres em relação a mulheres indígenas no Brasil. Ele nasce de uma parceria acadêmica construída em sala de aula, em um curso sobre gênero e direitos humanos nas relações internacionais ministrado entre 2017 e 2018 no Instituto de Humanidades, Artes e Ciências "Milton Santos", da Universidade Federal da Bahia. O curso propôs releituras de algumas teóricas feministas, sobretudo norte-americanas, que têm sido protagonistas no debate feminista desde os anos 1980. Nele analisamos instituições internacionais e questões mais pontuais, como as relações entre gênero e refúgio, gênero e raça, e o estupro em conflitos armados.

No Brasil, as hierarquias entre homens e mulheres têm sido questionadas de modo mais contundente nos últimos anos e a identidade de gênero passou a ser objeto tanto de amplo interesse quanto de acirradas disputas no debate público. Reler a profícua geração de teóricas feministas norte-americanas formada por Seyla Benhabib, Judith Butler e Nancy Fraser nos deu a oportunidade de reconhecer a contribuição e os limites das suas ideias ao nosso feminismo e ao debate público sobre direitos das mulheres no Brasil, que é, ao mesmo tempo, local e global. O curso também nos deu a rica oportunidade de olhar de distintos pontos de vista para normas, instituições, práticas e materiais sobre os quais temos nos debruçado.

Um desses materiais foi uma série de vídeos analisados no âmbito de uma parceria entre Denise Vitale e Renata Nagamine em pesquisa sobre mulheres no movimento indígena. Em artigo em coautoria, Nagamine e Vitale argumentaram que mulheres como Sônia Guajajara e Telma Taurepang são ativistas cosmopolitas enraizadas, para usar a categoria que Sidney Tarrow (2005) consagrou. São ativistas cosmopolitas, pois se engajam em questões de interesse global, que podem ser debatidas em círculos acadêmicos, como a Clacso, ou instituições globais, como as conferências da ONU. Para aí circular e atuar, as mulheres indígenas adquirem domínio sobre a gramática dessas arenas, o que implica perceber qual é a sua audiência e construir socialmente o problema para o qual 
almejam chamar a atenção usando códigos e repertórios próprios à arena em que se colocam. De outro lado, elas são enraizadas porque sua ação global tem em vista os seus interesses locais. Neste capítulo argumentamos que, para agir com eficiência no local e em escala global ao mesmo tempo, elas precisam atuar como mediadoras entre diferentes culturas. (MONTERO, 2006)

O cosmopolitismo das mulheres indígenas coloca em questão o modo como o global, o local e os feminismos costumam ser pensados nas Relações Internacionais. Se considerarmos a literatura antropológica, a presença de elementos cosmopolitas em aldeias indígenas não há de causar assombro. Missionários e índios que circulam por suas redes cristãs, especialmente católicas no Brasil, podem ser enquadrados como elementos de um cosmopolitismo aldeão. Também sabemos que mulheres indígenas se engajaram em diferentes causas políticas da esquerda em países latino-americanos - Rigoberta Menchú na Guatemala, Julieta Paredes na Bolívia -, e, no Brasil, elas ascenderam como lideranças no movimento indígena. Porém, apesar da liderança de mulheres como Sônia Guajajara e Telma Taurepang, a articulação de mulheres indígenas em torno de uma agenda comum ganha destaque apenas recentemente. Uma questão passa a ser, então, como o gênero ou os direitos das mulheres indígenas se tornam uma questão nas aldeias.

Nosso objeto remete ao debate mais geral sobre cosmopolitismo, tal como proposto por Immanuel Kant (2006) e Jürgen Habermas (1998). Não é o caso de reconstruir aqui essa linhagem, mas é importante reconhecer nela uma aposta na emancipação pela afirmação de uma ordem englobante das ordens nacionais e internacional. Para Habermas (1998, 2008), essa ordem tem sido construída especialmente desde o pós-Segunda Guerra mundial e suas formas mais bem-acabadas seriam a ONU e, sobretudo, os direitos humanos, o alcance que essa ideia moral logrou desde os anos 1940.

O entusiasmo com formas contemporâneas de cosmopolitismo, incluído o de Habermas, tem sido tomado como uma adesão insuficientemente crítica ao liberalismo, i.e., a seu universalismo abstrato, articulado a partir de uma ideia específica de sujeito, do qual marcadores sociais da 
diferença, como raça, cor, sexo, gênero teriam sido apagados. Teóricos pós-coloniais (CAHEN, 2013) estendem essa linha de argumentação às relações internacionais para assinalar os limites da igualdade formal das soberanias, seus usos para a reprodução das assimetrias entre estados e a persistência da civilização como um sinal diacrítico. Em qualquer hipótese, podemos apreender dos críticos de Habermas e do liberalismo (BUTLER, 2010; FRASER, 2013) que uma adesão ao universalismo liberal e a sua concepção de sujeito, teria por efeito a reprodução dessas hierarquias mediante um discurso emancipatório, que concorreria para escamotear os bloqueios à emancipação que ele mesmo erige. Para os teóricos-críticos que seguem as pegadas de Carl Schmitt nessa discussão específica, a defesa do universalismo, da humanidade, teria por fim enganar, a atacar seu cinismo, outros preferem assinalar o eurocentrismo ou mesmo o racismo que atravessa ou se cristaliza no universalismo liberal.

Elaborando sobre a teoria sociológica do processo político, Margaret Keck e Kathryn Sikkink (1998), e outros na esteira delas (ABU-LUGHOD, 2013) têm analisado como normas globais são apropriadas por atores situados em diferentes locais, assumindo sentidos e desempenhando papéis muito particulares. Esses estudos enfocam, sobretudo, como atores usam as normas globais e, no caso dos direitos humanos, como eles facilitam a articulação de redes transnacionais. (KECK; SIKKINK, 1998; TARROW, 2005) Para essa literatura, os direitos humanos são frames, ou enquadramentos interpretativos que os agentes usam atribuindo significado e para a construção de certas situações como problemas causados por determinados atores a determinar uma solução urgente. Não obstante serem normas globais, os direitos humanos são quadros de moldura ampla e elástica, que se prestam às mais distintas apropriações locais. (TARROW, 2005)

Keck e Sikkink (1998) olham para as mudanças que as redes de direitos humanos representam nas relações internacionais. Nessa literatura, o papel da retórica que embala os frames e os efeitos da ação política sobre os atores têm sido negligenciados - e eles nos parecem ser elementos importantes quando pensamos em situar e encarnar o sujeito dos direitos humanos como um universal sem abrir mão de seu potencial 
racionalizador da razão de estado (MARTY, 2014), produtor do humano dos direitos humanos (BUTLER, 2004) e transformador da humanidade, se a entendermos como construção social. O debate teórico-político, mais especificamente a produção de Benhabib (2004, 2006, 2012), oferece um caminho para repensar as relações entre local e global, o papel das normas globais nelas, o lugar do particular, da cultura e dos direitos nacionais, no universal. São fenômenos tocantes a essas questões que Benhabib pretende capturar com a categoria, ao mesmo tempo descritiva e normativa, "iterações democráticas", entendidas como meios para mediar a formação da opinião de maiorias democráticas e normas cosmopolitas. (BENHABIB, 2006)

Neste capítulo, queremos olhar para a atuação de um ator específico, a ONU Mulheres, na criação de condições para a constituição de uma agenda comum às mulheres indígenas no Brasil com base em normas globais de direitos humanos. Estamos interessadas no que nos parece ser um encontro profícuo para as mulheres e os povos indígenas. Pretendemos chamar a atenção para esse encontro e argumentar que, em se tratando das mulheres indígenas, a ONU Mulheres tem atuado menos como um ator político global do que como uma parte na mediação entre o local e o global. Olhar para sua atuação também nos convida a refletir, assim, sobre como temos pensado o global. Com essa análise, pretendemos contribuir com a discussão sobre o cosmopolitismo, mas também estamos interessadas em pensar como a atuação da ONU Mulheres em relação às mulheres indígenas pode iluminar a teoria de Benhabib e o debate teórico de RI.

\section{Os direitos humanos das mulheres: panorama histórico nas instituições internacionais}

No plano internacional, não distinguir em função de raça, sexo, língua ou religião é um propósito consagrado na Carta da ONU (art. 2(3)) e reaparece no preâmbulo da Declaração Universal de Direitos Humanos, de 1948, que ainda estabelece a não distinção de sexo, bem como a igualdade entre homens e mulheres em relação a temas específicos, como as relações familiares (art. 16). A ideia de que as mulheres são titulares de direitos 
humanos se estabelece, pois, na letra da ordem internacional nos anos 1940, o que representa um avanço em relação ao posicionamento prevalecente no plano interno de muitos estados à época e um constrangimento aos que ingressassem na sociedade internacional posteriormente a ela. ${ }^{2}$ Por isso, a inscrição do sexo como causa de não distinção, a declaração da igualdade entre homens e mulheres, p.e., no casamento e, em termos mais gerais, a forma de afirmar as mulheres como sujeito de direitos humanos foram objeto de disputas e negociações na redação da Carta e da Declaração. (MORSINK, 1991)

Nos primeiros anos de funcionamento da ONU, houve, p.e., um intenso debate acerca da necessidade de se fundar uma comissão dedicada às mulheres. Um dos argumentos contrários a ela era que "uma comissão separada de mulheres seria discriminatória e desnecessária na medida em que as questões das mulheres poderiam ser adequadamente tratadas pela Comissão de Direitos Humanos". (CHARLESWORTH; CHINKIN, 2013) Não obstante essas resistências, em 1946 foi instituída a Comissão sobre o Status das Mulheres (Commission on the Status of Women - CSW). Essa comissão, na realidade, ecoa o debate acerca dos direitos das mulheres na Liga das Nações, que se articulou internacionalmente por força da primeira onda do feminismo, seguiu discutindo o 'status das mulheres' e culminou na fundação de um comitê para esse fim. (EISENBERG, 2013) Nessa linha, a Comissão sobre o Status das Mulheres seria uma continuidade entre a Liga e a ONU, afastando o entendimento de que ela foi o primeiro órgão internacional a ter um mandato para fazer recomendações e promover a igualdade de direitos de homens e mulheres. Contra esse entendimento pode-se argumentar, contudo, que o comitê da Liga de fato respondia a demandas por igualdade de status, mas não por direitos humanos propriamente, porque a ideia de direitos humanos como direitos individuais tutelados internacionalmente era estranha à organização, que se ocupou prioritariamente dos direitos de minorias. (MAZOWER, 2008) Dessa ótica, a Comissão sobre o Status das Mulheres seria pioneira, e foi, com efeito, essencial para a elaboração de uma Declaração Universal dos

2 Neste capítulo não abordaremos a fascinante e pouco lembrada história dos direitos das muIheres na Liga das Nações. Sobre isso ver Miller (1994) e Eisenberg (2013). 
Direitos Humanos (1948) com uma linguagem mais sensível às questões de gênero.

Em compensação, a igualdade é declarada, primeiro, nas relações familiares, em que é acompanhada da afirmação da família natural e da declaração de que essa família é a base da sociedade, o que ilustra bem o processo político subjacente à negociação do texto da norma. Nesse processo, a própria declaração das mulheres como um sujeito de direitos no ato de declaração de direitos universais foi objeto de discussão, e embora a foto que correu o mundo ilustrando a adoção da Declaração de 1948 seja de Eleonor Roosevelt, a opção do Comitê de Redação foi o sujeito universal consagrado pelas declarações oriundas das revoluções modernas. Assim, em que pese o debate sobre os direitos humanos das mulheres e as mulheres como sujeitos de direitos humanos, a Declaração de 1948 não menciona sujeitos de direito específicos além da pessoa humana e ignora marcadores sociais da diferença, optando por afirmar sobre eles o caráter inato, i.e., natural desses direitos.

Dito isso, podemos tomar a especificação dos sujeitos de direitos humanos como um processo de desnaturalização da "pessoa humana" e de politização do humano dos direitos humanos (ASAD, 2003; BUTLER, 2004), no qual se evidenciam as relações de força que o constituem e de que modo construções culturais restringem o alcance da universalidade das formas. No caso das mulheres, esse processo requererá repensar a separação da vida em esfera pública e esfera privada, porque o acesso ao espaço público lhes teria sido negado historicamente. A isso se dedicarão os feminismos nos estados, sobretudo dos anos 1960 em diante.

Não podemos analisar, aqui, como eles o farão, mas propomos ao menos olhar a história recente dos direitos humanos das mulheres, em que o engajamento da ONU se confunde com a inauguração de um feminismo global. (OLCOTT, 2017) O marco desse engajamento é o Ano Internacional das Mulheres, por ocasião do qual a Comissão sobre o Status das Mulheres organizou a primeira Conferência sobre Direitos das Mulheres, na Cidade do México, em 1975 - anteriormente, portanto, à própria Convenção sobre Todas as Formas de Discriminação contra as Mulheres, de 1979. 
Na Conferência, ecoaram as demandas formuladas no processo de descolonização, implicando um aumento do número de estados-membros da ONU e, consequentemente, uma saliência maior das questões econômicas e sociais (HADDAD, 2007) nas relações internacionais, o que fica nítido no tema e no protagonismo das mulheres latino-americanas. Com o propósito de avaliar a implementação das recomendações da Comissão contra a Discriminação da Mulher e a participação feminina (HADDAD, 2007) no processo de desenvolvimento econômico e paz mundial, a Conferência do México foi a última de uma série e contou com um orçamento restrito, mesmo com o montante arrecadado a título de contribuição. Mas, se os recursos escassos mostram a desatenção da ONU à matéria, a articulação de um movimento global de mulheres nela assinala os usos transformadores que as mulheres reunidas na Cidade do México fizeram do espaço para encontros, trocas e negociações que a ONU lhes tinha aberto.

O momento era oportuno. O processo de contestação da ordem internacional deflagrado na Conferência de Bandung, em 1955, com a articulação do Movimento dos Países Não Alinhados, e a Guerra do Vietnã tinham desgastado a imagem dos Estados Unidos, que precisavam de uma plataforma a partir da qual dialogar com os países do Terceiro Mundo. Os direitos das mulheres, pouco conflituosos à época, teriam sido essa plataforma, de modo que o ano de 1975 aparece como marco de um segundo momento na história dos direitos humanos das mulheres, em que há um aumento na adoção de leis e programas governamentais de proteção. Com a Conferência teve início a “década de valorização da mulher”, que se estendeu de 1976 a 1985. Nele se elaborou a Convenção sobre a Eliminação de Todas as Formas de Discriminação contra as Mulheres (1979), que desdobrou os direitos das mulheres em direitos específicos e tutelados internacionalmente, e afirmou as mulheres como sujeitos de direitos humanos.

Os anos subsequentes ainda testemunharam avanços institucionais. Entre esses são habitualmente destacados a instituição do Comitê para a Eliminação da Discriminação contra a Mulher (CEDAW), formado por especialistas que fiscalizavam e monitoravam os estados no que diz respeito ao cumprimento da Convenção de 1979, e o Instituto Internacional 
de Pesquisa e Treinamento para o Progresso da Mulher (INSTRAW), responsável por estimular e auxiliar a coleta e disseminação de informações para o avanço das mulheres por meio da pesquisa. Relatórios preparados pela Comissão sobre o Status das Mulheres nos anos 1990 constataram, porém, que os avanços obtidos na Década das Mulheres não tinham sido suficientes para alcançar os objetivos propostos. Não obstante a implementação das estratégias de Nairóbi, muitos obstáculos persistiam. Para superá-los, a Assembleia-Geral da ONU determinou a realização da IV Conferência Mundial sobre a Mulher: Ação para a Igualdade, o Desenvolvimento e a Paz, a ser realizada em Pequim, na China, em 1995, por recomendação do Conselho Econômico e Social das Nações Unidas (ECOSOC). Nela, as preocupações de Nairóbi foram reiteradas, (NAÇÕES UNIDAS, 1996) com a demanda de se renovar, reformar e revitalizar partes do sistema das Nações Unidas, especialmente no que tange ao aumento do financiamento e status para a Divisão para o Avanço da Mulher (Division for the Advancement of Women (DAW), a fim de melhorar sua eficiência e eficácia.

Um aspecto crucial da Conferência de Pequim foi a associação, no âmbito das instituições internacionais, entre direitos das mulheres e direitos humanos, que a fórmula de Charlotte Bunch (1990) “direitos das mulheres são direitos humanos, direitos humanos são direitos das mulheres” consagrada pela primeira-dama dos Estados Unidos à época, Hillary Clinton, resume tão bem. A fórmula de Bunch circulou em um material do ativismo como parte de um esforço por encontrar uma ponte entre mulheres do Norte e do Sul, negras e brancas, do qual resultou a plataforma de combate à violência contra a mulher. (KECK; SIKKINK, 1998) O segundo aspecto fundamental de Pequim para o movimento feminista global foi o deslocamento da categoria "mulheres" para "gênero", em linha com o debate teórico e ideias da terceira onda do feminismo. Essa literatura já estabelecia que o gênero é uma interpretação do sexo com base em convenções e códigos sociais, ou, simplesmente, uma interpretação cultural do sexo, supostamente natural. Em 1995, Butler (2010) também já havia sustentado que o gênero não é só a interpretação do sexo com base na cultura, mas é uma interpretação que sustenta a ficção da naturalidade do 
sexo. Em contrapartida, argumentou-se na Conferência que gênero era uma categoria relacional e despolitizaria a luta das mulheres, entre outras razões, por abrir caminho para discussões relacionadas com a identidade de gênero e orientação sexual e distanciar o patriarcado como referência.

Quanto ao fim de conferir maior racionalidade e eficiência ao tratamento das questões relacionadas com as mulheres na ONU, uma decisão importante tomada na Conferência de Pequim foi a adoção da estratégia de "gender mainstreaming", ou transversalização de gênero. Nos anos 1990, essa estratégia se populariza como meio de corrigir a posição de desigualdade das mulheres a partir da promoção, pelos governos e outros atores, de "uma política ativa e visível de integração de uma perspectiva de gênero em todas as políticas e programas, de modo que, antes de as decisões serem tomadas, seja feita uma análise dos efeitos desta para os homens e mulheres". (CHARLESWORTH, 2005) A integração dessa perspectiva implicou na extensão da perspectiva de gênero a todas as áreas de trabalho das comissões e órgãos das Nações Unidas. O Conselho Econômico e Social identificou, então, uma série de diretrizes a serem observadas nesse processo (CHARLESWORTH, 2005), entre as quais: (i) trabalhar para que questões que atravessam diferentes áreas de atuação sejam elucidadas de forma que as diferenças de gênero possam ser identificadas e neutralizadas; (ii) a responsabilidade em traduzir a perspectiva de gênero na prática é de todo o sistema, e os resultados devem ser monitorados constantemente; (iii) a necessidade de esforços para ampliar a participação das mulheres nos centros de decisão; (iv) a não-comutabilidade da transversalidade do gênero pela necessidade de políticas, programas e ou leis específicos.

A implementação das diretrizes de Pequim esbarrava, no entanto, não na arquitetura descentralizada das Nações Unidas, que resultou numa fragmentação e sobreposição de órgãos e instâncias jurídicas e políticas, inclusive no que se refere às diversas convenções, conferências e declarações. Diante dessa debilidade institucional buscou-se um profundo programa de reforma durante o mandato do secretário-geral da ONU Kofi Annan (1996-2005) a fim de garantir maior eficácia às Nações Unidas otimizando suas funções institucionais. (CHARLESWORTH; CHINKIN, 
2013, p. 2) O escopo da reforma foi “a coerência do sistema”, em busca da transformação de um emaranhado de órgãos e instâncias em um instrumento mais efetivo à consecução das prioridades. O engajamento em prol deuma coordenação eficiente para enfrentar a fragmentação institucional tocou a agenda de gênero apenas em 2010, levando à criação da Entidade das Nações Unidas para a Igualdade de Gênero e o Empoderamento das Mulheres, conhecida como ONU Mulheres (ou UN Women).

\section{ONU Mulheres e mulheres indígenas: cenas de um encontro}

Na história sucintamente reconstruída na seção anterior, a Entidade das Nações Unidas para a Igualdade de Gênero e o Empoderamento das Mulheres, ou ONU Mulheres, emerge de um processo de reorganização da ONU empreendido por Kofi Annan e continuado por Ban Ki-moon com o propósito de gerenciar a fragmentação do sistema e, com isso, aumentar sua eficiência. Internamente ao sistema, a ONU Mulheres atua como secretariado da Comissão da ONU sobre o Status das Mulheres e articula a Divisão para o Avanço das Mulheres (DAW), o Instituto de Pesquisa e Treinamento para o Avanço das Mulheres (INSTRAW), o Escritório do Conselheiro Especial sobre Assuntos de Gênero (OSAGI) e o Fundo das Nações Unidas para o Desenvolvimento das Mulheres (UNIFEM). No mundo ela se propõe a implementar normas internacionais de direitos humanos com foco nos interesses das mulheres e atua para marcar presença em todos os continentes, com escritórios regionais.

De acordo com a ONU Mulheres, os principais marcos jurídicos de sua atuação são: (i) a Convenção sobre a Eliminação de Todas as Formas de Discriminação contra as Mulheres, de 1979; (ii) a Declaração e Plataforma de Ação de Pequim, de 1995; (iii) a Resolução 1325 do Conselho de Segurança sobre Mulheres, Paz e Segurança, de 2000; (iv) a Declaração do Milênio e Objetivos de Desenvolvimento do Milênio, de 2000. Como podemos notar, três entre os quatro documentos citados pela entidade consagram proposições que enquadramos como diretrizes políticas, não normas jurídicas, e por isso mesmo eles têm sido reiterados e ou atualizados com curta periodicidade (no caso da Declaração e Plataforma de 
Ação de Pequim, p.e., a cada cinco anos). Redeclará-los, i.e., reiterar sua enunciação é parte de seu processo de implementação. Esses padrões são menos densos normativamente e conferem menor alavanca à ONU Mulheres em relação aos estados; em compensação, prestam-se melhor a apropriações locais e à cooperação entre a entidade e governos, facilitando a articulação e a composição política. Nessa dinâmica, a Convenção sobre a Eliminação de Todas as Formas de Discriminação contra as Mulheres aparece como um mínimo denominador comum de juridicidade aos demais documentos.

Independentemente do modo como esses marcos se articulam, um ganho que a ONU Mulheres pode representar é situar o sujeito universal dos direitos humanos das mulheres e ajudar a enfrentar, através deles, outras hierarquias, como a racial, a sexual, a econômica, além da de gênero. No Brasil, p.e., ela tem apostado em parcerias com ONGs, órgãos de governo brasileiro e estrangeiros, agências, fundos e programas da ONU para atuar em relação a direitos civis, econômicos e sociais de refugiadas, negras e indígenas.

Nosso primeiro contato com a relação entre a ONU Mulheres e as mulheres indígenas se deu mediante um curto documentário, intitulado Voz das Mulheres Indígenas, que a entidade onusiana difundiu pelo Twitter. Produção de Glicéria Tupinambá e Cristiane Pankaru, ele foi lançado no Brasil em 2015, sendo objeto de debate em alguns espaços acadêmicos, ocasionalmente com a presença das próprias mulheres. O documentário apresenta mulheres de distintas idades e etnias, sobretudo do Nordeste, Norte e Centro-Oeste, falando sobre o que é ser uma mulher indígena, o que é ser índia, seu significado e desafios. Entre relatos de violência física e discriminação social em relação a si por homens indígenas, a seus povos e a seus filhos, elas respondem ao desafio lançado por um interlocutor inaudito de se comunicar com e a uma audiência não indígena assinalando que são mulheres e indígenas: são mulheres em sociedades em que as mulheres são inferiores aos homens - a sociedade indígena e a não indígena - e indígenas em uma sociedade em que homens, mulheres e crianças indígenas são inferiores aos não indígenas, a sociedade brasileira. Elas se afirmam como mulheres indígenas e reclamam direitos como tais, mas 
suas falas nos despertam para uma minoria dentre minorias e seus trânsitos entre potenciais espaços de sujeição. Em contraste com esses potenciais espaços, aquele em que estão reunidas e em que os depoimentos foram registrados aparece, assim, como um lugar de construção de subjetividade. Nele, índias de diferentes etnias se afirmam como mulheres, indígenas e sujeito de direitos, em contraposição à mulher que são na aldeia e à indígena que são na cidade.

O espaço em que se encontram não é o escritório da ONU Mulheres; mas é, de algum modo, criado por ela. A ONU Mulheres teria reunido mulheres indígenas de diferentes etnias em um mesmo local para dar início a um projeto homônimo ao documentário, financiado pela Noruega. O que a ONU Mulheres ajuda a criar não é, portanto, um espaço objetivo, mas um lugar de encontros e trocas, comunicação e (re)conhecimento, constituição de agentes e demandas por transformação dirigidas às sociedades indígenas e à brasileira como um todo. Trata-se, pois, de um espaço intersubjetivo, para falar com Hannah Arendt, constituído unicamente a partir do encontro das mulheres indígenas reunidas pela entidade da ONU e dependente de suas trocas recíprocas: um espaço, em suma, que as mulheres indígenas convidadas pela ONU Mulheres podem reconstituir em suas aldeias.

Em outro vídeo, veiculado em 2016, parte das indígenas que aparecem na peça de 2015 se encontra em Brasília, no escritório da ONU Mulheres, falando diretamente sobre o projeto Voz das Mulheres, os ganhos com as trocas nos dias que passaram juntas e sobre como pretendem atuar nas aldeias. Já há, portanto, uma ideia de sua forma de atuação, que é como 'multiplicadoras', levando e trazendo informações da ONU Mulheres para as aldeias e das aldeias para a ONU Mulheres, escutando e transmitindo as demandas das mulheres de suas aldeias. Mas o título da oficina, "Mulheres Indígenas e suas Estratégias em Defesa dos Direitos Indígenas", e sua descrição daquilo que os dias com a ONU Mulheres e o Voz das Mulheres representam para elas assinalam que o projeto se dedica a formar lideranças políticas para a defesa dos direitos indígenas. Isso nos permite entender as repetidas menções à importância de as mulheres 
estarem 'ao lado' dos homens, e não ‘competindo' com eles, bem como o tom e o teor de suas falas relacionadas com o gênero.

Essa compreensão dos sentidos e efeitos que o gênero assume para as mulheres indígenas a partir da ação da ONU Mulheres ilumina, ademais, uma diferença entre suas falas nos curtas de 2015 e de 2016. Neste último, elas parecem compartilhar uma linguagem com base na qual tratam das suas questões de gênero, não obstante pertençam a etnias distintas e lidem com desafios particulares em suas sociedades. Chama a atenção, em especial, o uso da categoria "empoderamento" - ausente no documentário de 2015 e recorrente nas peças da ONU Mulheres - e que uma ou outra ressalte a 'socialização de um vocabulário’ para falar de gênero como algo importante propiciado pelo encontro. Dados os usos e os discursos documentados em 2015 e 2016, empoderar significaria, no caso das mulheres indígenas, constituí-las como atrizes políticas aptas a interpelar sua condição em relação aos homens indígenas e o lugar dos povos indígenas no estado e os termos da cidadania no Brasil. Para tanto, elas se apropriam da sua condição de sujeitos de direitos humanos internacionais duplamente minoritários, como mulheres e indígenas. Como pertencentes a uma maioria demográfica historicamente transformada em minoria política e a uma minoria ancestral, as mulheres indígenas desafiam as relações desses dois grupos com o estado, a cidadania e o direito internacional, os termos de construção do demos e da humanidade. Na produção mais recente difundida pela ONU Mulheres, a ação política das mulheres indígenas é enquadrada como uma questão de direito e justiça.

Na peça, patrocinada pelo Canadá, a narração de uma mulher não indígena se sobrepõe a cenas registradas (i) na V Kuñangue Aty Guasu, ou Grande Assembleia das Mulheres Guarani e Kaiowá, que ocorreu em 2017 no Mato Grosso do Sul e contou com a presença de Nadine Gasman, representante da ONU Mulheres no Brasil, e (ii) no Acampamento Terra Livre de 2018, em que falou Luiza Carvalho, diretora regional da ONU Mulheres para Américas e Caribe. Nadine Gasman, Luiza Carvalho e a Ministra do Desenvolvimento Internacional e da Francofonia do Canadá, Marie-Claude Bibeau, falam no documentário, em que a narradora dá 
voz a mulheres indígenas, remetendo o espectador ao projeto Voz das Mulheres Indígenas.

Sua narração desfia ações e conquistas das mulheres indígenas, que são intercaladas com falas das próprias mulheres que esclarecem o significado da terra e das rezas para os povos indígenas. Um aspecto interessante desse documento é que a narração conta as ações de um ator político coletivo, "as mulheres indígenas". Ele trata as ações desse ator como se ele as precedesse, mas, como sabemos, não é esse o caso. Como um ator coletivo, as mulheres indígenas nos parecem ser um ator em construção incipiente. Perceber isso nos faz pensar que o documentário mostra, portanto, alguns momentos da constituição do coletivo "mulheres indígenas" e, ao mostrá-lo, também concorre para a sua constituição. Não por acaso, e diferentemente do que víamos nas outras peças, a narração menciona claramente a tônica das ações, "liderança e participação política", e sua "pauta nacional comum", elaborada com base nas demandas reunidas por vinte "multiplicadoras" no âmbito do projeto Voz das Mulheres Indígenas, que ouviram 104 dos 305 povos indígenas presentes no Brasil.

O documentário apresenta essa pauta, que abrange: (i) a violação dos direitos das mulheres indígenas, 'incluindo a violência contra as mulheres, mas não se limitando a ela'; (ii) o direito à terra e processos de retomada; (iii) o direito à saúde, educação e segurança; (iv) direitos econômicos; (v) o 'empoderamento’ político das mulheres indígenas; (vi) a formação de uma estratégia de 'incidência política'; (vii) tradições e diálogos intergeracionais; (viii) comunicação e processos de conhecimento; (ix) processos de resistência; (x) sustentabilidade e financiamento. Esses nos parecem ser, no entanto, grandes temas, não demandas pontuais, e alguns deles são esclarecidos pelas próprias mulheres, quando elas falam não só dos significados da terra e da reza para seus povos, mas do que é a educação para as crianças indígenas, da importância das tradições e do respeito à natureza, dos sentidos e momentos da luta dos indígenas pela terra, do papel da mulher nela, da falta de acesso das mulheres indígenas à saúde, ilustrada pelo atraso no pré-natal. Parte dessas dificuldades decorreria de que, nas palavras de uma das mulheres que fala no documentário, "parece que indígena não é gente". 
Sua articulação política - ressalta a narradora - tem lugar em 'espaços tradicionais de poder', para os quais a ONU Brasil pode ser convidada, como aconteceu na V Kuñangue Aty Guasu. O documentário destaca o papel da ONU no movimento de mulheres indígenas, mencionando a Comissão para o Status da Mulher e o Fórum Permanente dos Povos Indígenas (VITALE, 2014) como canais em que elas têm afirmado sua pluralidade e "capacidade de incidência”. O próprio fato de que Noruega e Canadá patrocinam suas ações assinala, enfim, a importância da cooperação internacional nesse movimento e a atenção da arena, ela mesma global, à questão de gênero.

Nessa linha de argumentação, entendemos que as interpelações das mulheres indígenas podem contribuir para desbloquear os caminhos à sua emancipação, bem como para a emancipação das mulheres e dos povos indígenas em geral. Entre tais bloqueios podem-se encontrar universais abstratos, usados para a reprodução de mulheres e indígenas como Outras. Mas, como sustentaremos na seção seguinte, trabalhar sobre bloqueios que as falas das mulheres indígenas mostram não implica descartar os direitos civis e os direitos humanos. Não implica, em síntese, recusá-los, mas abordar criticamente a sua universalidade, abrindo caminho para situá-los no tempo, no espaço, e encarná-los.

\section{'Um outro cosmopolitismo'? A contribuição de Benhabib ao debate entre universalistas e relativistas}

Conforme aventado na Introdução a este capítulo, o aprofundamento dos processos de globalização que marcam o cenário mundial a partir do fim da Guerra Fria levou a uma retomada do conceito de cosmopolitismo, revisitado através de diversos olhares. A proposta original apresentada por Kant em sua Paz Perpétua, no final do século XVIII, oferece pistas importantes para autores de referenciais teóricos distintos repensarem as possibilidades e os limites do potencial universalista e cooperativo do ideário kantiano.

Em “Kant's Idea of Perpetual Peace: At Two Hundred Years Historical Remove”, Habermas argumenta que, na proposta kantiana de 1795, Kant 
não podia vislumbrar uma comunidade internacional constitucionalmente organizada, pois o estado constitucional era exceção, não a regra. (HABERMAS, 1998) Contudo, o desenvolvimento político e institucional desde então permitiu que o projeto cosmopolita kantiano fosse adaptado às organizações internacionais, reformulando a concepção original. Habermas está convencido de que tal reformulação precisa enfrentar o problema de uma ordem global complexa e diversificada que pode ser entendida, contudo, como um estágio de transição entre a ordem internacional e a ordem cosmopolita. Nesse sentido, a paz significa um processo que “[...] visa não apenas a prevenção da violência, mas a satisfação das pré-condições reais para uma coexistência pacífica de grupos e pessoas”. (HABERMAS, 1998, p. 185)

Seguindo a análise habermasiana, o debate sobre a reformulação do projeto kantiano levou, por um lado, a propostas importantes no processo de reforma da ONU e, por outro, a críticas da retórica do universalismo. De fato, desde a metade dos anos 1990, em parte sob o estímulo do próprio processo de reforma da ONU, o debate sobre cosmopolitismo ganhou espaço no campo das instituições globais, num esforço por redefinir a democracia global. Autores como David Held e Daniele Archibugi propuseram a conexão entre cosmopolitismo e democracia, argumentando que desenhos institucionais contemporâneos encerram maior participação política nos níveis local, regional e internacional. (ARCHIBUGI 1998; HELD, 2010) O processo de democratização depende, assim, da criação de órgãos deliberativos nos níveis regional e internacional, além de um comprometimento com a democracia nos níveis local e nacional. Para os autores, se a democracia cosmopolita for um projeto sério, ela requererá uma reforma das instituições internacionais, que deve incluir a criação de um Parlamento Global, um sistema judiciário global e um Conselho de Segurança da ONU reestruturado, o que levaria a metas de curto, médio e longo prazo. (HELD, 2007)

Em contrapartida, os argumentos para a construção e o fortalecimento de instituições universais há tempos têm sido objeto de críticas que os qualificam de simples retórica. Carl Schmitt (2009) sintetiza bem essa visão cética do universalismo quando alerta para o fato de que ações em 
nome da humanidade podem esconder opressões e intenções de poder. Mais contemporaneamente, as críticas schmittianas ao potencial emancipatório do universalismo têm resultado em uma contestação do ideário cosmopolita, que, se argumenta, não pode ser uma mera expansão do modelo eurocêntrico para as demais partes do mundo, gerando ou um falso universalismo ou um universalismo hegemônico, capaz de escamotear configurações assimétricas. Nessa linha a busca por um ideal universal não poderia ser fundada em uma forma de vida particular ou em uma experiência social e política específica, por mais "progressiva”, “desenvolvida", "avançada” e "moderna” que ela seja.

Autores de diferentes correntes teóricas e epistemológicas endossam essa crítica. Sergio Costa (2006, p. 17), ao analisar o ideário cosmopolita à luz do racismo no Brasil, enfatiza que, não obstante as relevantes contribuições de autores como Habermas, Beck e Giddens, suas análises permanecem presas à metáfora do Atlântico Norte e não superam os limites de uma sociedade mundial monocêntrica, que celebra as "conquistas da modernidade". De outra parte, autores próximos dos estudos culturais e pós-coloniais desafiam ideais universais alegando que a modernidade não pode ser dissociada da escravidão e do colonialismo. Stuart Hall (1996) e Paul Gilroy (1993), autoridades nos estudos culturais negros no Reino Unido, propõem uma mudança epistemológica no campo das ciências sociais, desconstruindo o binário "West/Rest” e, em consequência, as relações de hegemonia contidas no discurso da modernidade, que pressupõe um processo de gradual “europeização” do mundo. A emergência e o desenvolvimento dos direitos humanos na Europa seriam contingentes e históricos, como são as relações estabelecidas pelo colonialismo europeu nas Américas, África e Ásia e as subsequentes lutas sociais de emancipação nas antigas colônias. A metáfora do Atlântico Negro evoca a análise da modernidade não como um processo linear e gradual, produzido pelo "West" e recebido pelo "Rest", mas como um processo dialético e complexo, resultante de histórias entrelaçadas na modernidade. (COSTA, 2006, p.39)

Seguindo o mesmo caminho e argumentando em base mais epistemológica, Raewyn Conell (2007) defende que é necessário repensar o 
conhecimento respeitando tradições intelectuais da periferia global. Assim, o estudo do Sul deve considerar os países nele situados não apenas como objeto, mas também como produtores de análise social e teórica. Apesar da predominância e da tradição das teorias sociais do Norte, sua perspectiva permanece limitada, já que trabalha com categorias produzidas no centro/metrópole e ignora ou marginaliza análises teóricas produzidas na periferia. Isso implica a necessidade de uma virada epistemológica ou, ao menos, uma maior abertura para um pluralismo epistemológico que inclua visões não-ocidentais de conceitos como progresso e desenvolvimento, sobretudo em temas afetados pelo colonialismo, como questões raciais e indígenas.

Walter Mignolo (2010), a seu turno, argumenta que o cosmopolitismo, como o globalismo, é principalmente uma questão de pensadores ocidentais e, nesse sentido, é unidirecional. Seguindo a crítica já esboçada, seu potencial universalista só pode ser pensado ao lado da sua dimensão pós-colonial. Deve-se, assim, adotar um duplo ponto de partida: a transformação da matriz colonial, que consolidou o imperialismo ocidental entre os séculos XVI e XX, e a imposição de uma descolonização do cosmopolitismo na esfera da sociedade política, especialmente expressa nos movimentos sociais. Desse modo, o desafio contemporâneo é substituir o cosmopolitismo eurocêntrico kantiano, mais bem definido como "localismo ocidental”, por um cosmopolitismo plural, não-ocidental, “já que há diversas memórias e feridas coloniais provocadas pelo racismo, formas de vida, linguagens, crenças, experiências conectadas ao Ocidente, mas ao mesmo tempo não subsumíveis a ele”. (MIGNOLO, 2010, p. 126-127) Mignolo não dá muitas pistas, contudo, de como aquela transformação e descolonização do cosmopolitismo ocorreriam. Ele indica os agentes desse processo, os movimentos sociais, que, no entanto, são, na prática, comprometidos com ideias e valores múltiplos e equívocos.

$\mathrm{Na}$ mesma direção, Eduardo Mendietta argumenta por uma concepção mais ampla de cosmopolitismo, que deveria substituir o que ele chama de modelo kantiano imperial. Embora Mendietta (2009, p. 253) reconheça Kant como "nossa maior fonte contemporânea de inspiração para o ideal cosmopolita" seu cosmopolitismo peca pela parcialidade 
de sua visão de mundo, expressa em seus escritos sobre Antropologia e Geografia Física, nos quais a superioridade dos povos europeus sobre os demais é manifesta. Essa premissa bloqueia outras narrativas referentes ao cosmopolitismo. Como alternativa, Mendietta propõe o que chama de cosmopolitismo dialógico, pensado a partir das propostas de Seyla Benhabib.

Com efeito, Benhabib (2004, 2006) desenvolve a ideia de iterações democráticas como um caminho para superar, ou ao menos diminuir, o abismo entre o direito positivo nacional e o direito cosmopolita, entre a soberania e a hospitalidade, um abismo que é reforçado pelo arcabouço formal das relações internacionais na medida em que os estados são protagonistas na sociedade internacional. Com a categoria "iterações democráticas" Benhabib pretende apreender trânsitos, trocas e transformações que se estabelecem entre o local, o internacional e o cosmopolita, que, cabe notar, tem uma relação de co-constituição com o processo. Para ela, essas relações tornaram-se muito mais fluidas, dinâmicas e intricadas (BENHABIB, 2006, p. 68) com o fim da guerra-fria. Como Benhabib (2006, p. 31) esclarece:

Embora territorialmente vinculados, os estados são gradualmente mais sujeitos às normas internacionais, sendo eles próprios, estados, os principais signatários e executores dos múltiplos tratados de direito internacional e convenções por meio das quais as normas internacionais se espalham. Nesse processo, o estado é tanto negado quanto reforçado em sua autoridade.

Benhabib está mais preocupada com as consequências do abismo entre direito positivo nacional e direito cosmopolita, soberania e hospitalidade em relação aos estrangeiros nas comunidades políticas. Seu olhar se lança, assim, sobre os Outros do demos. Mas a própria autora nuança sua análise ao afirmar que os Outros não estão necessariamente além-fronteiras e as fragilidades das distinções binárias entre nacionais e estrangeiros, cidadãos e migrantes diante de fenômenos políticos e sociais contemporâneos. Com essa nuance, notamos que Benhabib está olhando tanto para os Outros do demos quanto para o próprio demos, cuja constituição ela 
pressupõe ser histórica, i.e., estar em constante transformação. Em seu processo de constituição e ou transformação consideram-se diferenças de estrutura política e os muitos Outros da cidadania, sejam eles ou não cidadãos formais.

No entender de Benhabib nós estamos testemunhando um processo de "desintegração da cidadania", no sentido de que o conceito tradicional de cidadania tem mudado por força do direito comunitário, supranacional, e, podemos acrescentar, da precedência dos direitos humanos como ideia moral. (MOYN, 2010) Em linha com a argumentação de Benhabib, um dos efeitos desse processo seria a abertura de possibilidades para a reconstrução do demos a partir do desalinhamento de três termos: nacionalidade, ou identidade coletiva, pertencimento político, ou personalidade jurídica, e titularidade de direitos e benefícios sociais. Segundo Benhaibb (2006, p. 46), esses têm se separado na medida em que muitos residentes legais estrangeiros passaram a ter acesso a regimes de direitos civis e sociais, além de serem protegidos por legislações nacionais, i.e., local e supranacional.

Os direitos humanos têm contribuído para a reconstituição da comunidade política como ideias morais e proposições formais. Keck e Sikkink (1998) mostram que, como normas jurídicas, eles possibilitam a atores locais explorar vias internacionais para desbloquear vias nacionais. Benhabib contribui, ao seu turno, com essa literatura ao refletir sobre os usos dos direitos humanos como ideias morais e seus efeitos sobre os sujeitos, que se constituem em atores políticos no curso de ações demandando reconhecimento de sua condição de sujeitos de direitos. Na linha de argumentação de Benhabib, tais direitos possibilitam, em suma, situar os sujeitos no tempo, no espaço, e encarná-los. Em arenas democráticas, os trânsitos e as trocas que a autora pretende capturar com a categoria “iterações democráticas” abrem, além disso, a possibilidade de repetir um conceito, uma ideia ou uma norma internacional e, ao mesmo tempo, resignificá-los. Em suas palavras:

A iteração e a interpretação de normas, e de qualquer aspecto do universo de valor, nunca é, no entanto, meramente um ato de re- 
petição. Toda iteração envolve atribuir sentido a um original fidedigno em um novo e diferente contexto. $O$ antecedente, portanto, é reposicionado e resignificado via usos e referências subsequentes. O significado é reforçado e transformado (BENHABIB, 2006, p. 48). ${ }^{3}$

Para pensar como os sujeitos dos direitos humanos são situados, encarnados, e as normas internacionais resignificadas, Benhabib recupera um artigo chamado Nomos and Narrative, publicado pelo teórico do direito norte-americano Robert Cover no início dos anos 1980. Nesse escrito, Cover (1983) parte do pressuposto de que habitamos um mundo normativo para argumentar que por isso somos intérpretes das normas sociais, culturais e jurídicas que constituem o mundo que habitamos. Isso implica que, embora não tenhamos autoridade, tomamos parte na produção dos significados que essas normas assumem na vida social. Também implica que tanto os sujeitos dos direitos humanos quanto os sentidos que as normas universais assumem são locais, enquanto sua validade seria universal. Nos termos em que Benhabib a concebe, a categoria "iterações democráticas” pode ter alto rendimento analítico nas Relações Internacionais. Ela permite articular local e global de modo singular e produtivo, sem comprometer o potencial emancipatório dos direitos humanos. Permite, em síntese, localizar o global e universalizar o local através de agentes que ela cuida de situar e encarnar. Esses agentes, entre os quais mulheres indígenas e a ONU Mulheres, atuam em culturas distintas, entre as quais transitam e nas quais são produtores de significado. Com sua atuação eles facilitam a compreensão intercultural, sem supor que tudo pode ser traduzido ou que a cultura é estática. No caso das mulheres indígenas que falam aos documentários, elas nos parecem distinguir, interessantemente, cultura de práticas sociais, como o machismo, a desigualdade em participação ou sua maior ocupação com as coisas da casa e da família. Para transformar essas práticas sem transformar o que

3 "The iteration and interpretation of norms, and of every aspect of the universe of value, however, is never merely an act of repetition. Every iteration involves making sense of an authoritative original in a new and different context. The antecedent thereby is reposited and resignified via subsequent usages and references. Meaning is enhanced and transformed." 
é, para elas, sua cultura, tais mulheres lançam mão, contudo, de ideias, categorias e discursos aprendidos em trocas umas com as outras e com as funcionárias da ONU no espaço que a ONU Mulheres proporcionou. Entre essas ideias, categorias e discursos estão, como procuramos mostrar, os direitos humanos, os direitos dos povos indígenas, questões relacionadas com a educação e a saúde, a autonomia da mulher e, por conseguinte, sua participação nos assuntos tanto das sociedades indígenas quanto da sociedade não-indígena. Pensa-se que, falando ao seu modo em suas aldeias, elas os colocarão em circulação, reunindo as mulheres e buscando a compreensão dos homens.

\section{Considerações finais}

O debate sobre cosmopolitismo sintetizado na seção anterior reconhece a relevância do conceito para as sociedades contemporâneas. No entanto, suas contradições só podem ser superadas pelo processo político que contenha o fortalecimento da sociedade civil e dos movimentos sociais. Habermas direciona a solução das críticas inspiradas em Schmitt apontando para uma política de direitos humanos no contexto de uma ordem jurídica internacional. Para ele, direitos humanos universais, que estão no coração da ordem cosmopolita, devem ser interpretados como um projeto jurídico-político e, por conseguinte, definido deliberativamente pela comunidade política global. Numa proposta semelhante, Sergio Costa aposta em "contextos transnacionais de ação" influenciados por movimentos e redes transnacionais, mas eles só serão legítimos no nível nacional, pois concepções universalistas de sociedade civil seriam sempre parciais, i.e., uma parte do todo e, portanto, não teriam função legitimadora. Walter Mignolo (2011), ao seu turno, argumenta que o cosmopolitismo descolonizado que ele propõe deveria ser colocado dentro da esfera da sociedade política, como forma de tornar a "história invisível" - a história da colonialidade escondida atrás da história da modernidade visível. Finalmente, Mendietta confia na ideia de iterações democráticas de Benhabib, que descreveriam processos políticos democráticos interconectando o nacional e o universal. 
Neste capítulo mostramos o ganho que as elaborações de Benhabib, em especial a de iterações democrática, representam para a análise dos usos das normas internacionais de direitos humanos em esferas públicas nacionais e processos políticos transnacionais. Coma categoria “iterações democráticas" podemos tornar mais nítidos os efeitos e o potencial emancipatório de processos transnacionais em relação ao nacional. O ganho analítico que ela representa para a análise desses processos fica mais claro quando consideramos que muitas teorias de Relações Internacionais, como a abordagem construtivista de Keck e Sikkink (1998), olham prioritariamente para os efeitos deles no internacional ou em comportamentos de instituições nacionais, negligenciando a construção das próprias comunidades políticas. É para esse processo que Benhabib olha. Ela imagina as possibilidades que os direitos humanos abrem para se transformar um demos étnico em um demos cívico (BENHABIB, 2004, 2006), ou uma comunidade comprometida com a reprodução da nação em uma comprometida com a incorporação dos que são obrigados por suas leis no espaço da cidadania. Para Benhabib, como dissemos acima, isso resultaria na incorporação dos Outros da cidadania no demos.

No caso das mulheres indígenas, a ONU Mulheres, uma entidade global com atuação local, tem atuado como mediadora entre normas e instituições globais, a sociedade brasileira e as sociedades indígenas no Brasil. Mais recentemente, a partir de 2015, passou a atuar principalmente na formulação e implementação de projetos que ela também contribui para tornar concretos, mediante captação de recursos financeiros junto a outros governos, como o da Noruega e o do Canadá. No caso de seu principal projeto relacionado com a causa, o Voz das Mulheres Indígenas, a ONU Mulheres tem facilitado material e ideacionalmente a formação de espaços de troca e circulação de ideias, discursos e experiências.

Esses espaços são intersubjetivos e se formam quando a ONU Mulheres reúne mulheres indígenas em torno de um projeto comum. Neles têm lugar processos de subjetivação e reconhecimento, que passam pela percepção de si e das outras mulheres indígenas como mulheres e indígenas, mas também Outras em relação tanto à sociedade não-indígena quanto à sociedade indígena. Sua estraneidade é radical, porque o lugar 
de indígenas na sociedade brasileira - não-indígena - é singular, e nela se cruzam raça, cor e classe. Para tirar as mulheres indígenas dessa estraneidade em relação ao demos, sem assimilá-las ou facilitar sua assimilação à sociedade não-indígena, a ONU Mulheres aposta na capacidade das próprias mulheres de se situar em relação a suas sociedades e a sociedade brasileira. Ela tenta contribuir para a participação dos povos indígenas em ações globais e a ascensão das mulheres indígenas entre eles. Também lhes abre as vias globais para o ativismo em matéria de gênero. Por fim, e não menos importante, põe em circulação ideias, categorias, normas e discursos globais entre as mulheres indígenas. Com base no material publicado pela entidade onusiana, entre 2016 e 2018 as mulheres indígenas que atuariam como 'multiplicadoras' os colocaram em circulação, para a formulação de sua própria agenda, que não se confundiria com os interesses de suas sociedades, nem seria idêntica à agenda global feminista, apesar de convergente em temas como a violência contra a mulher. Para formular sua agenda junto às mulheres de suas sociedades, elas precisaram interpretar as ideias, categorias e normas globais para compreendê -las nas reuniões da ONU Mulheres, no debate público na sociedade não -indígena, e para esclarecê-las na aldeia. Os sentidos que essas normas ganharam no processo são, assim, locais, dialógicos e uma produção de cosmopolitas situadas.

\section{Referências}

ABU-LUGHOD, L. Do Muslim women need saving? Cambridge: Harvard University Press, 2013.

ARCHIBUGI, D. Principles of Cosmopolitan Democracy. In:

ARCHIBUGI, D.; HELD, D. H.; KOHLER, M. (Ed.). Re-imagining Political Community. Cambridge: Polity Press, 1998. p. 198-228.

ARENDT, H. Men in Dark Times. New York: Harcourt, Brace \& World, 1968.

ARENDT, H. The Human Condition. $2^{\text {nd }}$ ed. Chicago: The University of Chicago Press, 1998. 
ASAD, T. Formations of the Secular: Christianity, Islam, Modernity.

Stanford: Stanford University Press, 2003.

BENHABIB, S. Situating the Self: Gender, Community and

Postmodernism in Contemporary Ethics. Cambridge, UK: Polity, 1992.

BENHABIB, S. Sexual Difference and Collective Identities: The New

Global Constellation. Signs, v. 24, n. 2, p. 335-361, 1999.

BENHABIB, S. The Reluctant Modernism of Hannah Arendt. Oxford:

Rowman \& Littlefield, 2000.

BENHABIB, S. The Claims of Culture: Equality and Diversity in the Global

Era. Princeton: Princeton University Press, 2002.

BENHABIB, S. Another Cosmopolitanism. Oxford: Oxford University

Press, 2006.

BENHABIB, S. Dignity in Adversity: Human Rights in Troubled Times.

Cambridge, UK: Polity, 2011.

BENHABIB, S. The Future of Democratic Sovereignty and Transnational

Law: On Legal Utopianism and Democratic Skepticism. 2012. Strauss

Working Paper $03 / 12$.

BENHABIB, S. The Rights of Others: Aliens, Residents, and Citizens.

Cambridge, UK: Cambridge University Press, 2004.

BULL, H. The Anarchical Society: A Study of Order in World Politics. $3^{\text {rd }}$ ed. Basingstoke: Palgrave MacMillan, 2002.

BUNCH, C. Women's Rights as Human Rights: Toward a Revision of Human Rights. Human Rights Quarterly, v. 12, n. 4, 1990.

BUTLER, J. Undoing Gender. New York: Routledge, 2004.

BUTLER, J. Problemas de gênero: feminismo e subversão da identidade.

Tradução de Renato Aguiar. Rio de Janeiro: Civilização Brasileira, 2010.

CAHEN, M. O que pode ser e o que não pode ser a colonialidade: uma abordagem "pós-colonial" da subalternidade. São Paulo, 2013. (mimeo).

CHARLESWORTH, H.; CHINKIN, C. The creation of UN Women.

Canberra, Australia, 2013. RegNet research paper series, 2013/7. 
CHARLESWORTH, H. Not Waving but Drowning: Gender

Mainstreaming and Human Rights in the United Nations. Human Rights Journal, v. 18, p. 1-18, Spring, 2005.

CONELL, R. Southern Theory: The global dynamics of knowledge in social science. Cambridge: Polity Press, 2007.

COSTA, S. Dois Atlânticos: teoria social, anti-racismo, cosmopolitismo. Belo Horizonte: UFMG, 2006.

COVER, R. Nomos and Narrative. Harvard Law Review, v. 97, n. 4, p. 4-68, 1983/1984.

EISENBERG, J. The Status of Women: A Bridge from the League of Nations to the United Nations. International Organizations in Action, v. 4, n. 2, p. 8-24, 2013.

FRASER, N. Fortunes of Feminism: From State-Managed Capitalism to Neoliberal Crisis. London: Verso, 2013.

GEERTZ, C. Available Light: Anthropological Reflections on Philosophical Topics. Princeton: Princeton University Press, 2000.

GILROY, P. The Black Atlantic: Modernity and Double Consciousness. Cambridge, Mass.: Harvard University Press, 1993.

HABERMAS, J. The Inclusion of the Other: Studies in Political Theory. Cambridge, Mass.: The MIT Press, 1998.

HABERMAS, J. The Constitutionalization of International Law and the Legitimation Problems of a Constitution for World Society. Constellations, v. 15, n. 4, p. 444-455, 2008.

HADDAD, T. M. A. Diplomacia pública: a política externa brasileira e as ONGs na Conferência de Beijing (1995). 2007. Dissertação (Mestrado) - Instituto de Relações Internacionais, Pontifícia Universidade Católica do Rio de Janeiro, Rio de Janeiro, 2007.

HALL, S. The West and the Rest: Discourse and Power. In: HALL, S.; HELD, D. (Ed.). Modernity: an Introduction to Modern Society. Oxford: Blackwell, 1996.

HELD, D. Catastrophe in the Making: Globalization and the Environment. In: HELD, Da.; McGREW, A. (Ed.). Global Transformations. Stanford: Stanford University Press, 1999. p.375-413. 
HELD, D. Reconstructing world order: towards cosmopolitan social democracy”. In: HELD, D.; McGREW, A. Globalization/Antiglobalization. Cambridge: Polity Press, 2007. p. 206-220.

HELD, D. Cosmopolitanism. Ideals and Realities. Cambridge: Polity Press, 2010.

KANT, I. Toward Perpetual Peace and Other Writings on Politics, Peace, and History. New Haven: Yale University Press, 2006.

KECK, M.; SIKKINK, K. Activists beyond Borders: Advocacy Networks in International Politics. Ithaca: Cornell University Press, 1998.

MARTY, M. D. Direito penal do inumano. Tradução de Renata Nagamine. Belo Horizonte: Forum, 2014.

MAZOWER, M. No enchanted palace: The end of empire and the ideological origins of the United Nations. Princeton: Princeton University Press, 2008.

MENDIETTA, E. From imperial to dialogical cosmopolitanism. Ethics \& Global Politics, v. 2, n. 3, p. 241-258, 2009.

MIGNOLO, W. Cosmopolitanism and the De-colonial option. Studies in Philosophy and Education, v. 29, n. 2, p. 111-127, 2010.

MIGNOLO, W. The Global South and the Word Did/Order. Journal of Anthropological Research, v. 67, n. 2, p. 165-188, 2011.

MILLER, C. “Geneva - The Key to Equality”: Inter-war Feminists and the League of Nations. Women's History Review, v. 3, n. 2, p. 219-245, 1994.

MONTERO, P. (Ed.). Deus na aldeia: missionários, índios e mediação cultural. Rio de Janeiro: Globo, 2006.

MORSINK, J. Women's Rights in the Universal Declaration. Human Rights Quarterly, v. 13, n. 2, p. 229-256, 1991.

MOYN, S. The Last Utopia: Human Rights in History. Cambridge, Mass: The Belknap Press; London: Harvard University Press, 2010. [PELAS MULHERES INDÍGENAS] COMO É A VIDA DA MULHER INDÍGENA NA SUA ALDEIA?. [Produzido por] Mulheres indígenas. 2014a. 1 vídeo (5min). <https://www.youtube.com/ watch?v=AUQ7JoXNYog\&t=os\&list=PL3QmGlKtQQAjCPQdCV VVpOuQZoU3PyPoh\&index=14> . Acesso em: 22 set. 2018. 
[PELAS MULHERES INDÍGENAS] COMO É A VIDA DA MULHER INDÍGENA NA SUA ALDEIA?. [Produzido por] Mulheres indígenas. 2014b. 1 vídeo (5min). Disponível em: < https://www.youtube.com/ watch?v=AUQ7JoXNYog\&t=os\&list=PL3QmGlKtQQAjCPQd CVVVpOuQZoU3PyPoh\&index=14> . Acesso em: 22 set. 2018.

MULHERES INDÍGENAS VOZES POR DIREITOS E JUSTIÇA. [Produzido por] ONU Brasil. 2018. 1 vídeo (15minogs). Disponível em: $<$ https://www.youtube.com/watch?v=ZIellhtllao\&t=os\&list=PL3QmGlKt QQAjCPQdCVVVpOuQZoU3PyPoh\&index=51>. Acesso em: 22 set. 2018.

MULHERE-SE | CONEXCIDADES | INDÍGENAS - MULHERES PATAXÓS BLO1, [Produzido por] Programa Mulhere-se. 2016. 1 vídeo (13min28s). Disponível em: <https://www.youtube.com/ watch?v=OZoAqrvHIhE\&index $=14$ \&list=PL3QmGlKtQQ AjCPQdCVVVpOuQZoU3PyPoh>. Acesso em: 22 set. 2018.

MULHERE-SE | CONEXCIDADES | INDÍGENAS - MULHERES PATAXÓS BL02. [Produzido por] Programa Mulhere-se. 2016. 1 vídeo (10min49s). 2016. Disponível em: <https://www.youtube.com/ watch?v=nPHH-LBKKqg\&index $=15$ \&list=PL3QmGlKtQQ AjCPQdCVVVpOuQZoU3PyPoh>

NAÇÕES UNIDAS. Declaração de Beijing. In: CONFERÊNCIA MUNDIAL SOBRE A MULHER, (4., 1995, Pequim, China). IV Conferência Mundial sobre a Mulher. [Brasília]; Rio de Janeiro: Conselho Nacional dos Direitos da Mulher: Editora Fiocruz, 1996. Nota 51, para. 309.

OLCOTT, J. International Women's Year: The Greatest ConsciousnessRaising Event in History. New York: Oxford University Press, 2017.

SCHMITT, C. O conceito de politico. Translated by Geraldo de Carvalho. Belo Horizonte: Del Rey, 2009.

TARROW, S. The New Transnational Activism. New York: Cambridge University Press, 2005.

VITALE, D. Deepening Global Deliberative Democracy: The Participation of the Amazon Indigenous Peoples at the United Nations. Florence: European University Institute, 2014. Post-Doctoral Research Paper. 
10

\section{COM LENÇO, SEM DOCUMENTO:} gênero, apatridia e direito nas relações internacionais

Olívia Alves Barbosa 


\section{Introdução}

Este capítulo é fruto de uma pesquisa sobre apatridia que inicio no campo da antropologia. Ela tem origem no meu encontro com a história de Maha Mamo, que nasceu no Líbano, filha de pais sírios, e tornou-se apátrida em função das leis de nacionalidade dos dois países. Trata-se de uma história intrincada e mais comum do que pensamos. Reconto, aqui, alguns detalhes da história de Maha.

Os pais de Maha são sírios, mas pertencem a religiões diferentes. O casamento inter-religioso é ilegal na Síria, por isso, eles se mudaram para o vizinho Líbano, onde Maha e seus irmãos (uma mulher e um homem) nasceram. Se os critérios adotados em outros países se aplicassem na Síria, Maha seria uma cidadã síria. O direito sírio segue o princípio segundo o qual a nacionalidade é adquirida pelo sangue, i.e., transmitida pelos pais; porém, como seu pai é cristão e sua mãe muçulmana, eles não puderam registrar nem seu casamento, nem o nascimento dos filhos. Seria natural pensarmos que, nesse caso, Maha, nascida no Líbano, teria cidadania libanesa, mas a lei de nacionalidade no Líbano segue o mesmo princípio adotado na Síria, o do ius sanguinis, e não contempla a possibilidade de aquisição da nacionalidade com base no território de nascimento, conhecido como princípio do ius solis. (NAÇÕES UNIDAS, 2016) Sem adquirir a nacionalidade de qualquer dos países aos quais estava vinculada - a Síria por sua ascendência e o Líbano por seu local de nascimento Maha se tornou apátrida, ${ }^{1}$ ou seja, uma pessoa sem cidadania. Em termos práticos, isso significou para ela uma dependência da boa vontade, em

1 Apátrida é toda pessoa que não é considerada por qualquer Estado como seu nacional. Os Estados têm liberdade para estabelecer as regras para aquisição, mudança e retirada de nacionalidade. A Convenção de 1954 relativa ao Estatuto dos Apátridas é principal documento de direito internacional no que concerne a proteção de apátridas. As obrigações específicas relacionadas à prevenção e redução da apatridia são estabelecidas pela Convenção sobre a Redução da Apatridia, de 1961. O direto de todo o ser humano a uma nacionalidade também é garantido em diversos documentos de direitos humanos, a Declaração Universal dos Direitos Humanos; o Pacto Internacional sobre Direitos Civis e Políticos; a Convenção Internacional sobre a Eliminação da Discriminação Racial; a Convenção sobre a Eliminação de Todas as Formas de Discriminação contra a Mulher; a Convenção sobre os Direitos da Criança e a Convenção sobre os Direitos das Pessoas com Deficiência. 
uma palavra, da caridade alheia para ter acesso a serviços básicos, como educação e saúde.

Em 2013, Maha decidiu procurar uma solução para a sua condição e remeteu uma carta a todas as embaixadas em Beirute contando a sua história. A única resposta que recebeu veio da embaixada do Brasil, que na época recebia pedidos de refúgio por parte dos sírios. O diplomata brasileiro viu na nacionalidade dos pais de Maha uma janela de oportunidade para ajudá-la e concedeu um laisser-passer para que ela e seus irmãos entrassem no Brasil. Em 19 de setembro de 2014, os três jovens, todos na faixa dos 20 anos, chegaram ao país e obtiveram seu primeiro documento de identidade na vida, com seu nome e sua foto, como Maha não se cansa de realçar em suas entrevistas. Com isso, eles ganharam a chance de recomeçar, mas também passaram a compartilhar da sorte dos brasileiros. Em 2016, o irmão de Maha, Eddy, foi vítima de um assalto por mão armada em Belo Horizonte. Mal falando português, ele demorou a atender aos assaltantes e sua lentidão, interpretada como resistência, foi respondida com tiros por queima-roupa. Poucos meses após chegar ao Brasil e depois de alguma discussão com diplomatas libaneses no país, o corpo de Eddy retornou ao Líbano, onde tinham ficado seus pais.

Passados quatro anos da sua chegada, a antes trilíngue Maha agora também fala português fluentemente e circula pelo mundo. Mesmo antes de adquirir a cidadania brasileira, sua identidade e seu passaporte já lhe permitiam viajar dentro do Brasil e para diversos países como embaixadora informal da campanha \#IBelong, da ONU. (UNHCR, 2016) Essa campanha, liderada pelo Alto Comissariado das Nações Unidas para Refugiados (ACNUR), pretende acabar a apatridia até 2024. Para sensibilizar a comunidade internacional para o problema da apatridia, ela reconta a história de centenas de pessoas que, pelas mais distintas razões, vivem como apátridas em todo o mundo.

Neste capítulo me proponho a pensar de que modo o gênero pode contribuir para a produção da apatridia, um status individual de privação da nacionalidade que me parece ter se configurado em dado momento como um problema de interesse global. Para pensar a respeito, mostrarei o entrelaçamento de normas jurídicas e histórias individuais com base em 
um levantamento documental ainda em curso. Depois, farei uma análise preliminar desse material desde uma perspectiva cosmopolita, partindo do pressuposto de que se trata de uma questão de justiça.

\section{Histórias individuais, normas globais e ações transnacionais}

Pesquisando no site da campanha \#IBelong, e já movida pelo drama de Maha Mamo, eu me deparei com a história de outra apátrida habitante do Líbano, que se chama Rama. Seu sobrenome não é mencionado e são poucos os detalhes de sua história, mas foi ela que primeiro me chamou a atenção para como o gênero participa na produção da apatridia. Passo, então, a recontá-la, com as escassas informações que se encontram no material da campanha.

Rama é uma menina de nove anos que, como Maha, nasceu no Líbano, filha de mãe libanesa, e, diferentemente de Maha, com pai apátrida. Por que seu pai é apátrida? A \#IBelong não fornece qualquer informação a respeito, mas, a julgar pela fala de outros apátridas registrada para a campanha, seu silêncio pode ter relação com questões de segurança. Mesmo Maha menciona, em dado momento, que ela pode falar porque está no Brasil legalmente, mas não falaria se fosse apátrida, comentário que podemos interpretar como uma afirmação de que falar em público lhe colocaria em risco de ser expulsa do país. No caso de Rama, esse silêncio é eloquente, porque ela de certo modo herdou a apatridia do pai. Essa herança é, contudo, fruto de um arranjo jurídico-político-social muito particular. No Líbano, as mulheres não têm, afinal, os mesmos direitos à cidadania que os homens. Em termos práticos, se uma mulher libanesa se casa com um estrangeiro, ela não pode passar sua nacionalidade para os filhos ou o seu cônjuge. Ela não participa, portanto, na decisão de quem pertencerá ou não ao demos, e este não é o caso dos homens, que são autorizados por lei a passar sua nacionalidade a filhos e cônjuge. Rama teria se tornado apátrida, assim, em razão da diferença entre homens e mulheres inscrita na lei libanesa no que se refere à transmissão e aquisição da nacionalidade. (UNHCR, 2015) 
O problema seria menor se se limitasse ao Líbano, mas, de acordo com o ACNUR, este não é o único país em que a nacionalidade é transmitida apenas por homens. Outros vinte e cinco países, concentrados no Oriente Médio, no norte da África e na África subsaariana, elaboram suas leis de nacionalidade de modo similar. ${ }^{2}$ Sessenta países regulam diferentemente o modo como homens e mulheres adquirem, mudam ou conservam sua nacionalidade. Entendo que sua legislação consagra na letra da lei uma discriminação por gênero, i.e., um tratamento desigual com base no gênero, que coloca milhares de mulheres e crianças à margem da cidadania e é injustificado à luz do direito internacional.

Desde essa ótica, a desigualdade de gênero viola a Convenção sobre a Eliminação de Todas as Formas de Discriminação contra as Mulheres, que determina aos Estados-partes outorgar às mulheres direitos iguais aos dos homens para adquirir, mudar ou conservar sua nacionalidade e (ii) os mesmos direitos do homem no que diz respeito à nacionalidade dos filhos (artigos $2^{\circ}$ e $9^{\circ}$ ). Além das violações à Convenção sobre Discriminação contra as Mulheres, a diferença entre homens e mulheres nas leis de nacionalidade viola outras convenções internacionais, incluindo a Convenção sobre os Direitos da Criança (artigos $2^{\circ}, 7^{\circ}$ e $8^{\circ}$ ) e o Pacto Internacional sobre os Direitos Civis e Políticos $\left(\operatorname{artigos} 2^{\circ}, 3^{\circ} \mathrm{e}\right.$ 24). Por fim, a Declaração Universal dos Direitos Humanos, adotada pela Assembleia Geral da ONU em 1948, também assegura o direito à nacionalidade, i.e., o direito à personalidade jurídica (artigo 15).

Esse diploma não desfrutou nos anos 1940 do status jurídico que alcançou ao longo das décadas e mesmo sua juridicidade foi contestada. Já atualmente suas normas são consideradas costumes internacionais e materialmente superiores à maioria das demais normas internacionais. Mas a Declaração Universal foi celebrada nos anos 1940 e a enunciação pública de que todos têm direito à nacionalidade desde uma instituição internacional global respondia à constituição da apatridia como fenômeno

2 Os demais países que não permitem que as mulheres transmitam sua nacionalidade para filhos e maridos são: Mauritânia, Libéria, Togo, Líbia, Sudão, Somália, Burundi, Suazilândia, Líbano, Síria, Iraque, Jordânia, Kuwait, Arábia Saudita, Qatar, Emirados Árabes Unidos, Omã, Irã, Bahrain, Brunei Darussalam, Malásia, Kiribati, Bahamas e Barbados. 
tocante às relações internacionais. Foi dessa perspectiva que o analisou Hannah Arendt (2012), pioneiramente, ainda nos anos 1950.

No capítulo quinto de seu primeiro grande livro, Origens do totalitarismo, publicado na íntegra em 1951, Arendt reflete sobre a produção de massas de refugiados e "pessoas sem Estado", stateless ou apátridas, no pós-Primeira Guerra mundial e suas implicações para as relações entre Estados europeus. Situando sua discussão em um debate mais amplo acerca do imperialismo, Arendt (2012) caracteriza esses grupos de pessoas a partir de sua relação com a lei do território em que se encontravam e com sua comunidade política de destino. Na descrição arendtiana, refugiados e apátridas, embora formalmente distintos, eram indistintos no nível da vida prática e se encontravam fora do alcance da lei. Estavam, em suma, fora de qualquer espaço de igualdade formal ou material, dependendo, por isso, da caridade, e não da lei, de seus talentos, e não de seus atos. Nas palavras de Arendt (2012, p. 434), “[...] uma vez fora do país de origem, permaneciam sem lar; quando deixavam o seu Estado, tornavamse apátridas; quando perdiam os seus direitos humanos, perdiam todos os direitos: eram o refugo da terra." Para a autora, o caráter inédito do fenômeno descrito não estava na perda do lar, mas na impossibilidade de encontrar um novo lar para os apátridas, pois para ela não havia mais lugar algum disponível na terra em função da organização política dos Estados. Para todos os fins, a humanidade havia se tornado uma.

Da análise da condição de refugiados e apátridas no pós-Primeira Guerra, Arendt (2012) conclui que, embora os direitos humanos fossem declarados inatos e inalienáveis, aqueles que tinham perdido a nacionalidade também os perdiam todos. Perdiam o direito de ter qualquer outro direito. O fenômeno da apatridia ajuda a autora a iluminar, assim, os limites dos direitos humanos e uma espécie de condição necessária deles, que ela resume na fórmula direito a ter direitos.

Uma das coisas que impressionam nas Origens do totalitarismo é perceber que a produção de pessoas sem cidadania perdurou ao longo de décadas até os nossos dias. A forma de lidar com esse fenômeno tem sido a elaboração de convenções internacionais que assegurem alguma proteção aos indivíduos que estão fora do alcance de qualquer sistema jurídico 
nacional. No esforço por assegurar aos apátridas o mais amplo exercício dos direitos e liberdades fundamentais, as Nações Unidas aprovaram dois tratados, que formam a estrutura jurídica internacional para o tratamento do tema.

O primeiro deles, a Convenção sobre o Estatuto dos Apátridas, de 1954, é a mais abrangente codificação dos direitos dos apátridas em vigor e conta com noventa Estados-parte. (UNITED NATIONS, 1954) A Convenção de 1954 define a "pessoa apátrida" como toda pessoa que não seja considerada por qualquer Estado, segundo a sua legislação, como seu nacional. Aos que se qualificam como apátridas, a Convenção estabelece uma estrutura mínima para a sua proteção internacional, garantindo-lhes, por exemplo, os mesmos direitos de que desfrutam os cidadãos no que diz respeito à liberdade religiosa e à educação dos filhos. Ela também lhes assegura o mesmo tratamento dedicado a outros não nacionais na fruição de direitos como a liberdade de associação, o emprego e a habitação. Para superar a vulnerabilidade que afeta as pessoas que vivem na condição de apátridas, a Convenção ainda defende o direito à liberdade de circulação, exige o fornecimento de documentos de identidade e proíbe a expulsão daqueles que estão legalmente no território do Estado-parte.

Já a Convenção sobre a Redução da Apatridia, de 1961, é o segundo instrumento internacional que compõe a base internacional de proteção dos apátridas. Ela conta atualmente com 71 Estados-parte e resultou de mais de uma década de negociações internacionais. (UNITED NATIONS, 1961) A Convenção regulamenta o artigo 15 da Declaração Universal de Direitos Humanos, que garante a todos o direito a uma nacionalidade e, subjacente a ela, está a noção de que, embora os Estados sejam soberanos para elaborar suas leis de nacionalidade, eles devem fazê-lo em conformidade com as normas internacionais, incluindo o princípio de que a apatridia deve ser evitada. Um foco central da Convenção de 1961 é a prevenção da apatridia ao nascer, exigindo que os Estados concedam cidadania a crianças nascidas em seu território ou que sejam descendentes de seus nacionais. Tal Convenção busca evitar, enfim, a apatridia no contexto da transferência de território ou por perda, renúncia ou privação de nacionalidade. 
Em termos práticos, a apatridia pode decorrer de diferentes situações. Nas últimas décadas, a formação de Estados, a transferência de territórios e a mudança de fronteiras têm sido sua causa mais frequente. Outras causas comuns são a perda de nacionalidade ou impossibilidade de sua aquisição a partir de mudanças legislativas, falhas ou ausência de registro de nascimento e o conflito entre leis de nacionalidade. Esses conflitos são bastante comuns, porque os países são livres para eleger diferentes princípios para a aquisição e transmissão de nacionalidade: como as histórias de Maha e Rama ilustram, enquanto alguns países concedem a nacionalidade para indivíduos nascidos em seu território de acordo com o princípio ius solis, outros conferem nacionalidade apenas para os descendentes de seus nacionais de acordo com o princípio ius sanguinis. Mesmo assim, esses princípios não são homogêneos, pois que são moldados de acordo com a vontade de cada comunidade nacional. Eu me surpreendi, por exemplo, ao descobrir que, entre 1994 e 2007, duzentos mil filhos de brasileiros nascidos no exterior se tornaram apátridas em razão de uma alteração constitucional aprovada em $1994^{3}$ que limitava a aquisição de nacionalidade ao princípio ius solis e, com isso, negava a cidadania brasileira a filhos de brasileiros nascidos no exterior. ${ }^{4}$

Seja como for, se a apatridia como fenômeno global decorre da organização política da vida dos Estados em sociedade, ele é um problema político, que requer uma solução política - e um número importante de Estados tem procurado enfrentá-lo. Considerando uma literatura de Relações Internacionais que possibilita analisar relações interno-internacional, ou

3 De acordo com a Emenda Constitucional de Revisão n 3, de 07 de junho de 1994, a alínea "c" do inciso I, do art. 12 da Constituição Federal passava a vigorar com a seguinte redação: os nascidos no estrangeiro, de pai brasileiro ou de mãe brasileira, desde que venham a residir na República Federativa do Brasil e optem, em qualquer tempo, pela nacionalidade brasileira.

4 De acordo com a emenda, a nacionalidade só seria concedida aos residentes no Brasil ou que optassem pela cidadania brasileira perante um juiz federal, após completar 18 anos de idade. A questão foi resolvida com a Emenda Constitucional $n^{\circ} 54$, de 24 de setembro de 2007, que consagrou o princípio do ius sanguinis e restituiu a nacionalidade brasileira nata aos filhos de brasileiros nascidos no exterior. Com a Emenda Constitucional n ${ }^{54}$, de 2007 , a alínea c do inciso I do art. 12 da Constituição Federal passou a vigorar com a seguinte redação: os nascidos no estrangeiro de pai brasileiro ou de mãe brasileira, desde que sejam registrados em repartição brasileira competente ou venham a residir na República Federativa do Brasil e optem, em qualquer tempo, depois de atingida a maioridade, pela nacionalidade brasileira. 
local-global, e a formação das normas nas relações internacionais, uma percepção dessa mudança de posição no plano doméstico teria possibilitado ao Alto Comissariado das Nações Unidas para Refugiados lançar a campanha \#IBelong em 2013 com intuito de acabar com a apatridia em dez anos, atuando como uma espécie de "promotor" normativo, de um valor que se pretende erigir a norma internacional.

No lançamento da campanha, o ACNUR divulgou seu plano de ação global para solucionar o problema entre os anos de 2014 e 2024, desenvolvido em conjunto com Estados, sociedade civil e organizações internacionais. Esse plano visa resolver situações existentes de apatridia, impedir o surgimento de novos casos e identificar e proteger os apátridas. Dez ações foram consideradas fundamentais para atingir o objetivo visado: (i) resolver as principais situações existentes de apatridia; (ii) garantir que nenhuma criança nasça sem Estado; (iii) eliminar a discriminação por gênero nas leis de nacionalidade; (iv) impedir a negação, perda ou privação da nacionalidade por motivos discriminatório; (v) prevenir a apatridia nos casos de sucessão do Estado; (vi) conceder status de proteção aos migrantes sem Estado e facilitar sua naturalização; (vii) assegurar o registro de nascimento para a prevenção da apatridia; (viii) emitir documentação de nacionalidade para aqueles com direito a ela; (ix) aceder às Convenções da Apatridia da ONU; (x) melhorar dados quantitativos e qualitativos sobre populações apátridas.

Como as causas, o perfil e a dimensão da apatridia variam, nem todas as ações são necessárias em todos os países. Na maioria deles, apenas uma ou duas ações serão suficientes para acabar com todos os casos. De acordo com o ACNUR, a garantia da igualdade de gênero nas leis de nacionalidade pode atenuar os riscos da apatridia, especialmente da apatridia na infância, que ocorre quando (i) o pai é apátrida; (ii) as leis do país do pai não permitem a atribuição de nacionalidade em certas circunstâncias, como quando a criança nasce no exterior; (iii) o pai é desconhecido ou não é casado com a mãe no momento do nascimento; (iv) o pai não consegue cumprir as medidas administrativas para conferir a nacionalidade ao filho porque morreu, foi separado de sua família ou não pode arcar com 
os custos de uma documentação onerosa; ou (v) o pai não está disposto a cumprir as medidas administrativas para conferir a nacionalidade.

Historicamente, a maioria dos países considerava que a nacionalidade de uma criança derivava do pai. No entanto, ao longo do século XX, a maioria dos Estados promulgou reformas reconhecendo que não apenas as mulheres merecem igualdade, mas a sociedade se beneficia quando os filhos de todos os cidadãos, sejam eles homens ou mulheres, são incluídos na cidadania. Em muitos casos, uma reforma legislativa relevante estendeu às mulheres o direito de conferir nacionalidade a seus filhos. Nos últimos 15 anos, reformas foram realizadas em países tão diversos quanto Sri Lanka (2003), Egito (2004), Argélia (2005), Indonésia (2006), Iraque (reforma parcial em 2006), Marrocos (2007), Bangladesh (2009), Zimbábue (2009), Quênia (2010), Tunísia (2010), Iêmen (2010), Mônaco (2005, 2011), Senegal (2013), Suriname (2014), Madagascar (2017) e Serra Leoa (2006, 2017). Da perspectiva teórica de Relações Internacionais, as reformas nesses países podem assinalar um processo de formação de norma internacional e pressionar os 25 países que ainda consagram a discriminação de gênero na aquisição, transmissão e conservação da nacionalidade a alterarem suas legislações nacionais. Contando com a possibilidade de formação de um consenso internacional em torno do tema, o ACNUR pretende que até 2024 todos os Estados tenham leis de nacionalidade que tratem mulheres e homens igualmente. Desde o início da campanha, em 2013, dois Estados - Serra Leoa e Madagascar - já alteraram suas legislações, promovendo a igualdade entre todos nas leis de nacionalidade.

A \#IBelong compartilha com outras campanhas da ONU a aposta ao apelo a histórias individuais, narradas pelos próprios afetados e ou enfocando o impacto da prática a ser combatida na vida das crianças. Temos aqui um amplo uso de pessoas que nossas convenções sociais tendem a considerar mais vulneráveis, mulheres e crianças, e um apelo à linguagem dos direitos. Um elemento a considerar é que se tem aqui, um uso estratégico dessas formas específicas. Mas a interação silenciosa com as convenções sociais é ambivalente. A campanha também realça os efeitos que a discriminação de gênero tem desempenhado na apatridia e procura salientá-la para angariar apoio público e constranger formuladores de 
políticas. O público da campanhaé, no entanto, um público global, não circunscrito às fronteiras territoriais dos Estados que mais respondem pela produção da apatridia, e esse público global pode compreender no todo ou em parte o público desses Estados. Um elemento interessante sobre o qual refletir é que uma estratégia semelhante foi central na campanha pelos direitos de nacionalidade das mulheres no Líbano, onde as crianças afetadas e suas famílias aparecem frequentemente no centro das manifestações diante do Parlamento, atraindo atenção significativa da mídia. (COLLECTIVE FOR RESEARCH \& TRAINING ON DEVELOPMENT ACTION, 2018) Outra estratégia utilizada foi o apelo a valores tradicionais centrados na unidade familiar e no bem-estar da família nacional. ${ }^{5}$

No que tange às pressões e incentivos internacionais, cabe destacar o papel dos órgãos internacionais na promoção da igualdade de gênero nas leis de nacionalidade. Existe um crescente consenso internacional de que é benéfico para as sociedades acabar com a discriminação contra as mulheres e os Estados procuram apresentar-se como favoráveis aos direitos das mulheres. Nesse sentido, embora nem todos os tratados internacionais sejam aplicados internamente, muitos governos se preocupam com sua reputação internacional, como sabemos da literatura teórica em Relações Internacionais. Por isso, o ACNUR salienta que as revisões periódicas realizadas por órgãos de direitos humanos são oportunidades úteis para destacar o descumprimento de obrigações de direitos humanos e têm influenciado os processos de reforma em vários casos.

5 No Quênia, como parte dos esforços para garantir o apoio aos direitos de nacionalidade das mulheres na nova Constituição, a Federação de Mulheres Advogadas e outros ativistas quenianos apelaram aos avôs pedindo que imaginassem como seria se seus netos não fossem quenianos simplesmente porque suas filhas se casaram com homens estrangeiros. Da mesma forma, os ativistas libaneses enfatizam ainda hoje que, ao invés de contradizer a religião, garantir o acesso das crianças à nacionalidade da mãe está de acordo com os valores religiosos que promovem o bem-estar da criança e a santidade da família. Muitos líderes políticos libaneses afirmam que o sistema confessional de governo do país, que atribui poder político de acordo com o tamanho das comunidades religiosas, seria prejudicado se a lei fosse reformada, uma vez que a demografia do país poderia mudar. A falha deste argumento se torna evidente quando preocupações semelhantes não são expressas em relação a possíveis mudanças demográficas que ocorreriam com a concessão de nacionalidade aos filhos de homens libaneses e mulheres estrangeiras. 
Consagrando esse entendimento, no evento paralelo à $32^{\mathrm{a}}$ sessão do Conselho de Direitos Humanos, denominado "Igualdade de Direitos das Mulheres em Direito e Prática”, representantes da Argélia e Madagascar enfatizaram que a atenção dos mecanismos de direitos humanos incentivava seus governos a promoverem os direitos de nacionalidade das mulheres. (UNITED NATIONS, 2016) Além disso, durante a reunião ministerial do ACNUR, em 9 de dezembro de 2011, Libéria e Togo comprometeram-se a alinhar suas leis de nacionalidade com a garantia de igualdade entre homens e mulheres prevista em suas Constituições. Seu compromisso público tem sentido porque relatores especiais apontaram que quatro Estados africanos - Burundi, Libéria, Sudão e Togo - consagraram o princípio da igualdade de gênero em constituições recentes, mas ainda precisavam reformar as disposições relevantes de suas leis de nacionalidade. (UNHCR, 2011) Em princípio, as disposições constitucionais prevalecem sobre a lei da nacionalidade em cada Estado, mas, como as leis de nacionalidade são específicas, as autoridades administrativas têm aplicado as disposições mais antigas dessas leis em vez de se apoiar nas garantias constitucionais de igualdade de gênero.

\section{Igualdade de gênero e a transmissão da nacionalidade: uma questão de justiça}

O consenso internacional em torno da igualdade de gênero na transmissão da nacionalidade tem se ampliado. É crescente o número de países que reformaram ou pretendem reformar suas legislações nacionais para dar fim a causas de apatridia. Também, a construção da apatridia como um problema global e sua ascensão como uma questão de justiça, ou uma questão normativa, nas relações internacionais desperta Estados como o Brasil, que agem para buscar soluções domésticas e internacionais. O Brasil, por exemplo, trata da apatridia de um modo geral em sua Nova Lei de Migrações. Na Somália, ao seu turno, um recente projeto da lei de cidadania pretende abolir as disposições discriminatórias e, entre outras coisas, permitir que as mulheres somalis confiram nacionalidade a seus filhos em igualdade de condições com os homens. Em alguns contextos, 
a promoção da igualdade de gênero nas leis de nacionalidade está incluída em esforços mais amplos para promover a igualdade de gênero. Por exemplo, as reformas da legislação de nacionalidade na Argélia e no Marrocos foram realizadas em conjunto com outras reformas que visavam ampliar os direitos das mulheres e estabelecer uma perspectiva de igualdade de gênero perante as leis, em especial na regulação do direito de família.

O processo político que tem buscado a construção de consenso em torno do tema da apatridia no geral e da produção de apátridas por questões de gênero em particular se estende ao plano regional. Nesse plano, a cooperação tem contribuído com movimentos de reforma bem-sucedidos, que tendo a perceber como reformistas e transformadores ao mesmo tempo.

Entre esses movimentos destaco a campanha regional das Mulheres Árabes pela Nacionalidade, lançada na primeira década do século XXI e que ilustra bem a importância dos intercâmbios regionais para transformações locais. No final dos anos 2000, reformas foram feitas em oito países árabes: Argélia, Egito, Iraque, Marrocos, Líbia, Palestina, Iêmen e Tunísia. No entanto, doze países da região do Oriente Médio e Norte da África - Líbia, Líbano, Síria, Iraque, Jordânia, Kuwait, Arábia Saudita, Catar, Emirados Árabes Unidos, Omã, Irã, Bahrain - não permitem às mulheres transmitir sua nacionalidade aos seus filhos. No Catar e no Kuwait, ${ }^{6}$ por exemplo, as leis não permitem que as mães confiram nacionalidade aos seus filhos: esse é um interdito absoluto, que se impõe mesmo resultando em apatridia. Já as leis de nacionalidade da Jordânia, Líbia, Arábia Saudita e Emirados Árabes Unidos só permitem que as mulheres confiram nacionalidade aos seus filhos em determinadas circunstâncias, como quando os pais são desconhecidos, sem nacionalidade ou não estabelecem filiação. No Iraque, embora a Constituição estabeleça a igualdade de gênero em relação à nacionalidade, as mulheres não podem conferir nacionalidade aos filhos nascidos fora do país. Na Síria e no Bahrein, as mães só podem conferir nacionalidade se a criança nascer em seu território e

6 Os parlamentos do Bahrein e do Kuwait estão atualmente examinando propostas para revisar suas respectivas leis de nacionalidade e considerar reformas que permitiriam às mulheres conferirem cidadania aos seus filhos. 
o pai for desconhecido ou não estabelecer filiação. Sob a lei de Omã, as mães só conferem nacionalidade no caso de o pai ser desconhecido ou antigo cidadão omani.

Outras leis discriminatórias de gênero, incluindo alguns status pessoais e códigos penais, podem resultar na negação da nacionalidade às crianças da região. Por exemplo, o casamento inter-religioso e o sexo fora do casamento, mesmo em casos de estupro, são ofensas punidas com penas de prisão em alguns países. Jordânia, Arábia Saudita e os Emirados Árabes permitem que as mães concedam nacionalidade aos filhos quando o pai é desconhecido; todavia, o sexo fora do casamento pode resultar em diferentes punições. Na Jordânia, o sexo consensual fora do casamento pode resultar em três anos de prisão e crianças nascidas fora do casamento são frequentemente removidas à força dos cuidados maternos. Como mostramos, na Síria e no Líbano casamentos inter-religiosos são proibidos e mesmo os homens não podem registrar seus filhos nascidos fora da relação matrimonial.

Seis países da África - Mauritânia, Libéria, Togo, Sudão, Somália, Burundi, Suazilândia - não oferecem às mães igualdade de direitos na transmissão da nacionalidade, o que coloca milhares de crianças sob o risco de apatridia. Em outros países do continente, como Guiné e Mali, há diferença de tratamento entre mulheres e homens no que diz respeito à atribuição de nacionalidade aos seus filhos. No entanto, apesar da natureza discriminatória dessas leis, salvaguardas gerais contra a apatridia impedem que crianças nascidas em seu território se tornem apátridas. Embora haja resistência à igualdade de gênero em relação aos direitos de nacionalidade, os países africanos têm avançado na matéria com numerosas reformas bem-sucedidas nos últimos anos e a deflagração de processos de revisão legislativa, como no Togo, na Libéria e no Sudão. No início de 2018, o Conselho de Ministros do Sudão aprovou um projeto de lei que permitirá às mulheres sudanesas conferir sua nacionalidade às crianças no caso de o pai ser proveniente do Sudão do Sul, da mesma forma que um pai sudanês pode conferir a sua nacionalidade ao filho quando a mãe é sudanesa do sul, mas não há um projeto de lei que preveja a igualdade entre mulheres e homens na transmissão da nacionalidade. 
Essas mudanças no Sudão inquietam em relação ao que está em jogo quando se trata do interdito (ou da permissão) de transmissão da nacionalidade que recai sobre as mulheres. Não se trata de uma questão de igualdade ou discriminação de gênero per se, mas de um instrumento para assegurar a reprodução da nação conforme certos critérios normativos em países em que a cidadania estaria ancorada nela. Porém, a afirmação da não-discriminação por gênero em matéria de nacionalidade parece ter um efeito desestabilizador da naturalidade da nacionalidade, mas também dos papéis de gênero. Não por acaso, os argumentos, preocupações e medos expressos por aqueles que se opõem às reformas apresentam notável similaridade. Grosso modo, em um grande número de países os opositores à igualdade de gênero defendem que o papel natural do pai é o de chefe de família. Esse papel estaria na raiz da identidade familiar e seria, portanto, a única fonte legítima da nacionalidade. Outros atores utilizam justificativas religiosas ou argumentam que a limitação da transferência de nacionalidade pelos homens tem o condão de manter a unidade familiar, pois ela garantiria a mesma nacionalidade a todos os membros da família. Esses argumentos mostram que interpretações, sentidos, ideias e categorias religiosas, sociais e culturais são usados para assegurar o modo de produção e de reprodução da nação.

Embora a maioria das justificativas invoque valores tradicionais, tenta-se, enfim, associar a não-transmissão da nacionalidade pela mulher ao colonialismo, com o argumento de que os elementos discriminatórios das leis de nacionalidade foram herdados do governo colonial pelos novos Estados pouco depois de obterem sua independência das antigas potências e não foram revogadas desde então. Esse argumento é interessante porque recupera um fato histórico e o torna, a ele e o colonialismo, importante no presente. Nele, o uso do passado escamoteia a escolha presente de manter o status quo no futuro, em lugar de transformá-lo, com a integração das mulheres na produção da nacionalidade. Isso significa, primeiro, que ele entrelaça a história política a histórias individuais, as relações internacionais à constituição da nacionalidade, e isso não sob a ótica dos direitos humanos, como nos pareceria, atualmente, mais natural, mas sob uma ótica colonialista ou imperialista. Também significa que 
reprodução biológica, reprodução político-social e reprodução cultural são processos descontínuos. Uma das coisas que estão em jogo nessa discussão é, afinal, a possibilidade de alinhá-las, e é curioso que o bloqueio a seu alinhamento se justifique apelando a algo superior à reprodução da nação, que seria, pensando com Benhabib (2006), assegurar as condições para reprodução de um demos étnico. Nessa linha, estender às mulheres a transmissão da nacionalidade implica aceitar a possibilidade de uma integração transformadora da constituição do demos, que tende a se tornar cívico, isto é, ancorado na cidadania.

Como se pode notar, as resistências a essa transformação perpassam diferentes continentes, culturas e religiões. Elas não são algo do passado, e sim do presente. Tanto é que, não obstante os argumentos contrários à igualdade de gênero pareçam perder força, eles também são acolhidos em alguns países. Nas Bahamas, o referendo de junho de 2016 permitia que a população colocasse fim à discriminação de gênero nas leis de nacionalidade e estabelecesse a igualdade entre homens e mulheres. A maioria da população optou por manter a desigualdade de gênero nas leis de nacionalidade e a reforma constitucional não foi levada adiante. $O$ fracasso ocorreu em grande parte por causa de falsas conexões entre reformas de nacionalidade, igualdade de gênero e casamento entre pessoas do mesmo sexo, com a oposição contando com altos níveis de homofobia e insatisfação com o Governo que estava promovendo a reforma. Aqueles que entendem que a identidade da família é derivada do pai também expressam temores de que os filhos de homens estrangeiros assumam lealdade ao país do pai. No Nepal, por exemplo, a fronteira com a Índia é frequentemente citada como uma justificativa para a concessão desigual de direitos de nacionalidade entre homens e mulheres, o receio é que filhos de homens indianos possam ultrapassar em quantidade os filhos de homens nepaleses. De acordo com a lei nepalesa, as crianças nascidas no Nepal filhas de mulheres nepalesas e pais estrangeiros podem solicitar a cidadania por naturalização, desde que tenham domicílio permanente no Nepal e não tenham adquirido a cidadania estrangeira do pai. 


\section{Conclusão}

Este capítulo abordou as relações entre gênero e apatridia. Procuramos mostrar que não se trata apenas de uma questão de igualdade ou discriminação de gênero per se, mas da reprodução da nação conforme certos critérios normativos. Tentamos descrever, como alguns países têm utilizado suas leis de nacionalidade como instrumento para circunscrever a ideia de cidadania na discriminação de gênero. Diante das reformas legislativas que ocorreram em diferentes locais do globo, procuramos refletir sobre o modo como a afirmação da não discriminação por gênero em matéria de nacionalidade teve um efeito desestabilizador não apenas na naturalidade da nacionalidade, mas também dos papéis de gênero. Esse argumento nos pareceu correto diante da constatação da similitude das preocupações e medos expressos por aqueles que se opõem às reformas legislativas. Grosso modo, os opositores à igualdade de gênero defendem que o papel natural do pai é o de chefe de família e seria, portanto, a única fonte legítima da nacionalidade. Além disso, utilizam justificativas religiosas ou argumentam que a limitação da transferência de nacionalidade pelos homens tem o condão de manter a unidade familiar. Com isso, pudemos constatar que interpretações, sentidos, ideias e categorias religiosas, sociais e culturais têm sido utilizadas para garantir o modo de produção e de reprodução da nação.

\section{Referências}

ARENDT, H. Origens do totalitarismo. Tradução de Roberto Raposo. São Paulo: Companhia das letras, 2012.

BENHABIB, S. Another cosmopolitanism. New York: Oxford University Press, 2006.

COLLECTIVE FOR RESEARCH \& TRAINING ON DEVELOPMENT - ACTION. Arab Women's right to nationality campaign. Available on: $<$ http://www.crtda.org.lb/project/nationality>. Access on: 16 nov. 2018. 
BRASIL. Emenda Constitucional de Revisão nº 3, de o7 de junho de 1994. Disponível em: <http://www.planalto.gov.br/ccivil_o3/Constituicao/ Emendas/ECR/ecr3.htm>. Acesso em: 16 nov. 2018.

BRASIL. Emenda Constitucional n ${ }^{0}$ 54, de 2007. Disponível em: $<$ http:// www.planalto.gov.br/ccivil_03/constituicao/emendas/emc/emc54.htm>. Acesso em: 16 nov. 2018.

NAÇÕES UNIDAS. Alto Comissariado para Refugiados . Maha Mamo, refugiada apátrida no Brasil, fala sobre os desafios de uma vida sem nacionalidade. São Paulo, 2016. Disponível em: <http://www.acnur.org/ portugues/2016/12/15/maha-mamo-refugiada-apatrida-no-brasil-falasobre-os-desafios-de-uma-vida-sem-nacionalidade/>. Acesso em: 16 nov. 2018.

UNHCR. 9 year old Rama thinks being stateless is unfair. Available on: $<$ http://www.unhcr.org/ibelong/9-year-old-rama-thinks-being-statelessis-unfair/>. Access on: 16 nov. 2018.

UNHCR. Campanha \#IBelong. Available on: <http://www.unhcr.org/ ibelong/>. Access on: 16 nov. 2018.

UNHCR. Maha Mamo, a stateless refugee in Brazil, talks about the challenges of a life without nationality. 2016. Available on: $<$ http://www.unhcr.org/ ibelong/maha-mamo/>. Access on: 16 nov. 2018.

UNHCR. Pledges 2011. Ministerial Intergovernmental Event on Refugees and Stateless Persons. Geneva, 2011. Available on: $<$ http://www.unhcr. org/commemorations/Pledges2011-preview-compilation-analysis.pdf $>$. Access on: 16 Nov. 2018.

UNITED NATIONS. Convention relating to the Status of Stateless persons. New York, 28 Sept. 1954. (Treaty Series, v. 360). Available on: $<$ https:// treaties.un.org/Pages/ViewDetailsII.aspx?src=TREATY\&mtdsg_no=V$3 \&$ chapter $=5 \&$ Temp=mtdsg2\&clang=_en $>$. Access on: 16 nov. 2018.

UNITED NATIONS. Convention on Reduction of Statelessness. New York, 30 Aug. 1961. (Treaty Series, v. 989). Available on: <https:// treaties.un.org/Pages/ViewDetails.aspx?src=TREATY\&mtdsg_no=V4\&chapter $=5 \&$ clang=_en $>$. Access on: 16 nov. 2018. 
UNITED NATIONS. Human Rights Council.32nd session of the Human Rights Council (13 June to 1 July and 8 July 2016). 2016. Available on: <https://www.ohchr.org/EN/HRBodies/HRC/RegularSessions/ Session32/Pages/32RegularSession.aspx>. Access on: 16 Nov. 2018. 


\section{O FEMINISMO DAS}

GUERRILHEIRAS CURDAS

DE ROJAVA

Vitória Moreira 


\section{Introdução}

Em julho de 2012, em meio à chamada Primavera Árabe, onda de protestos que varreu diversos países do Oriente Médio contra o autoritarismo de antigas ditaduras, o oeste da Síria testemunhou um fenômeno singular. Na cidade de Kobanî, o regime de Bashar Al Assad foi expulso por guerrilheiros curdos, dentre os quais se destacavam mulheres de tranças longas que logo se tornaram símbolo de resistência feminina em veículos de mídia ao redor do mundo. Mais tarde, no final de 2013, foi a vez do grupo terrorista Estado Islâmico (ISIS) tentar capturar a cidade. Após alguns meses de ocupação, entretanto, o grupo foi fortemente repelido pelas forças curdas.

Esses foram apenas alguns sinais de um novo fator na política da região: a formação de uma comunidade autônoma, criada pelos curdos, em meio à guerra civil síria. Nessa comunidade, em que a emancipação das mulheres é anunciada como prioridade política, surge um novo feminismo, associado à crítica do Estado-nação e ao autoritarismo.

Neste artigo, busco apresentar a chamada "revolução de Rojava" - região do norte da Síria - e refletir sobre o seu feminismo, analisando suas raízes e seus principais aspectos teóricos. Não é meu objetivo aqui me aprofundar na análise do "feminismo curdo", entendido como movimento feminista mais amplo, historicamente associado aos movimentos de mulheres e inserido no contexto das lutas de liberação do povo curdo. Embora tal movimento de mulheres, que emergiu na Turquia nos anos 1980, seja um precedente do feminismo de Rojava, seus objetivos e o caráter de sua mobilização diferem do feminismo em foco.

Analisarei, portanto, o feminismo que emergiu com a autodenominada revolução de Rojava, em 2012, na Síria. Para isso, primeiramente contextualizarei a revolução e apresentarei suas ideias subjacentes. Em seguida, voltarei a atenção aos aspectos feministas proclamados por ela, buscando situar seus preceitos com base em teóricas feministas, em especial, Nancy Fraser (2007) e Lila Abu-Lughod (2012). Na minha pesquisa,

1 Para críticas ao destaque conferido às guerrilheiras, ver Dirik (2014), Diyar (2015) e Stanzo (2016). 
realizei revisão bibliográfica de artigos acadêmicos e de jornais on-line, além da análise documental de alguns pronunciamentos das combatentes da guerrilha feminina curda, veiculados em inglês, em meio digital.

\section{Primavera curda}

Os curdos, uma comunidade distinta de pessoas unidas por raça, cultura e línguas, estão presentes na Turquia, Armênia, no Irã, Iraque e na Síria, onde correspondem a aproximadamente 7 a 10\% da população. (WHO..., 2017) Com a chegada da Primavera Árabe na Síria, em fevereiro de 2011, os curdos da Síria, historicamente reprimidos e, em muitos casos, privados do reconhecimento de cidadania, ${ }^{2}$ faziam coro com a parte da população síria que tomou as ruas em oposição à ditadura de Bashar Al Assad. Inicialmente organizados de forma clandestina, os curdos da região norte do país definem-se como uma "terceira força” (KNAP; FLACH; AYBOGA, 2016, p. 50), entre os defensores do regime e o oposição, cada vez mais radical, que almeja tomar o poder. As vozes curdas em Rojava dizem defender a democracia e almejam estabelecer uma forma de governo que seja livre da opressão do regime e das amarras do neoliberalismo. Diferentemente dos curdos do Iraque, que reivindicam o estabelecimento do Curdistão, o movimento de liberação dos curdos sírios acredita que o Estado-nação está ultrapassado no mundo da globalização; eles defendem algo mais democrático, feminista e etnicamente inclusivo, e estão tentando construir isso em Rojava. (TAX, 2016a, p. 19)

2 Os curdos têm uma longa história de marginalização e perseguição política, especialmente no Iraque e na Turquia, países onde são mais numerosos e nos quais promoveram diversas revoltas em busca de maior autonomia ou de independência. (COUNCIL ON FOREIGN RELATIONS 2017) A história de repressão contra os curdos na contemporaneidade remonta à assinatura do acordo Sykes-Picot, em maio de 1916, entre França e Grã-Bretanha. O acordo dividiu o Império Otomano, onde os curdos habitavam, em esferas de influência desses dois países e, com isso, definiu as divisões políticas da região pelo resto do século XX. Com o estabelecimento de novos Estados, o Curdistão foi desmembrado e os curdos perderam o reconhecimento de sua etnia e diversos direitos políticos, o que provocou revoltas nos anos 1930, combatidas com políticas de repressão vigentes até os dias de hoje. (KNAPP; FLACH; AYBOGA, 2016) Ver também Council on Foreign Relations (2017) e Who... (2017). 


\section{Confederalismo Democrático}

O clamor por uma governança curda, descentralizada e guiada por princípios comunitaristas, baseia-se nas ideias do ex-líder do Partido dos Trabalhadores Curdos (Partiya Karkerên Kurdistanê, ou PKK), Abdullah Öcalan. Em 1974, Öcalan, um ex-estudante universitário de Ciência Política curdo-turco, fundou o PKK como uma organização marxista com o objetivo de estabelecer um Curdistão independente ao sudeste da Turquia. (COUNCIL ON FOREIGN RELATIONS, 2017) Inicialmente, o partido não foi levado a sério, mas, aos poucos, ganhou simpatizantes entre os curdos privados de seus direitos. (COUNCIL ON FOREIGN RELATIONS, 2017) Em 1980, um golpe militar na Turquia levou a liderança do PKK a fugir para a Síria. Entretanto, quatro anos mais tarde, a organização começou a usar da violência e de táticas terroristas contra o Estado turco e contra curdos que não apoiavam sua causa, o que fez com que, em 1988 e sob pressão militar da Turquia, a Síria assinasse o Acordo de Adana, se comprometendo a pôr um fim ao seu apoio ao PKK (COUNCIL ON FOREIGN RELATIONS, 2017). Com isso, Öcalan foge mais uma vez. Em 1997, o PKK foi incluído na lista de organizações terroristas dos Estados Unidos e, dois anos mais tarde, Öcalan foi preso em Nairóbi por agentes da Turquia com o apoio dos Estados Unidos. (COUNCIL ON FOREIGN RELATIONS, 2017) Na Turquia, Öcalan foi condenado à prisão perpétua por traição e confinado à solitária em uma ilha fora de Istambul, onde permanece até hoje. (COUNCIL ON FOREIGN RELATIONS, 2017; MOGELSON, 2017)

Apesar da Turquia ter esperado que o PKK se desintegrasse sem seu líder, na realidade, o partido se fortaleceu pela luta que se seguiu à prisão de Öcalan. Agora que estava na prisão, as tremendas forças intelectuais de Öcalan poderiam se voltar para uma estratégia política de longo alcance ao invés de questões táticas e organizacionais com as quais outros poderiam lidar tão bem quanto ele. Isso signi- 
ficou que a liderança coletiva que toda revolução precisa teve mais espaço para emergir. ${ }^{3}$ (TAX, 2016a, p. 155, tradução nossa)

Tendo criado um sistema de organização capaz de funcionar mesmo com a sua ausência (TAX, 2016a), e isolado na ilha de Imralî, Öcalan passou a se dedicar à leitura. (MOGELSON, 2017) Com isso, deixou de lado sua antiga orientação marxista-leninista para buscar uma nova saída política para o problema do não reconhecimento do povo curdo. Guiado por princípios anticapitalistas e feministas, Öcalan formulou uma teoria de governo que denominou Confederalismo Democrático, uma abordagem contrária à centralização e a favor do autogoverno em nível local.

Inspirado no "anarquismo verde" (CUNHA; KARADA, 2015) do filósofo americano Murray Bookchin, e com claras influências marxistas, Öcalan defende um modelo de democracia radical, conferindo destaque especial ao combate ao patriarcado e defesa do meio ambiente. Öcalan foi particularmente influenciado pela defesa de Bookchin do "municipalismo libertário": a proposição de que, para combater governos capitalistas opressores, os cidadãos devem criar confederações ou assembleias populares que funcionem como um sistema paralelo dentro dos Estados. (MOGELSON, 2017) Segundo Öcalan, “o Confederalismo Democrático é aberto a outros grupos e facções políticas. Ele é flexível, multicultural, antimonopolístico e orientado para o consenso. Ecologia e feminismo são pilares centrais". (ÖCALAN, 2015, p. 122)

Segundo a filosofia de Öcalan, o desenvolvimento da centralização estatal está intimamente ligado à subjugação e à exploração das mulheres (KNAPP; FLACH; AYBOGA, 2016, p. 10). Sua teoria enfatiza a jinealogia, uma forma de revisão feminista da história, e a agroecologia. Assim, ele propõe uma "sociedade moral e política” autogovernada através de uma democracia popular direta, na qual as fronteiras são superficiais.

3 "Though Turkey had expected the PKK to fall apart without its leader, it was actually strengthened by the struggle that developed after Ocalan's arrest. Now that he was in prison, Ocalan's tremendous intellectual strengths could be focused on long-range political strategy rather than tactical and organizational questions which others could handle as well as he. This meant that the collective leadership that every revolution needs had more room to emerge." 
Mas, acima de tudo, o Estado nacional deve ser pensado como a forma máxima de poder. Nenhum dos outros tipos de Estado tem tal capacidade de potência. Uma das principais razões para isso é que a parte superior da classe média foi ligada ao processo de monopolização de modo sempre crescente. O próprio Estado nacional é o monopólio completo mais desenvolvido. É a unidade mais desenvolvida dos monopólios, em termos comercial, industrial, financeiro e energético. Deve-se também pensar em monopólio ideológico como parte indivisível do monopólio do poder. (ÖCALAN, 2015, p. 118)

\section{$[\ldots]$}

Nosso projeto de 'modernidade democrática' é concebido como um projeto alternativo à modernidade como nós a conhecemos. Ele baseia-se no Confederalismo Democrático como um paradigma político fundamental. A modernidade democrática é a morada da sociedade política de base ética. Enquanto nós cometermos o erro de acreditar que as sociedades precisam ser entidades homogêneas monolíticas, será difícil compreender o confederalismo. A história da modernidade é também a história de quatro séculos de genocídio cultural e físico em nome de uma sociedade unitária imaginada. O Confederalismo Democrático, como categoria sociológica, é a contraparte dessa história e se baseia na determinação de combater, se necessário, do mesmo modo pela diversidade pela diversidade étnica, cultural e política. (ÖCALAN, 2015, p. 124)

As ideias de Öcalan não ficaram só no papel. No sudeste da Turquia, o movimento pela autonomia democrática começou em 2005, quando a Associação de Comunidades do Curdistão (KCK) - uma organização guarda-chuva de grupos da rede do PKK - começou a experimentar programas com a população pobre e urbana da região, criando órgãos de autogoverno e procedimentos bottom up de tomada de decisão. (TAX, 2016a, p. 155) Ao longo dos anos, a transformação política do movimento de liberação dos curdos continuou a evoluir em contraponto à luta armada, a resistência civil e a política eleitoral. (TAX, 2016a, p. 155-156) O PKK 
se comprometeu a adotar táticas flexíveis - incluindo a necessidade de negociações de paz - e passou a atuar, junto com um novo partido parlamentar na Turquia e com ativistas locais, promovendo o desenvolvimento de estruturas de governo alternativas ao do Estado turco. (TAX, 2016a, p. 156-157)

Em 2011, prevendo um longo e brutal conflito na Síria, o Partido da União Democrática (Partiya Yekîtiya Demokrat, ou PYD), criado em 2003 filiado ao PKK, ${ }^{4}$ viu uma oportunidade de fortalecer seus esforços prévios de instituição de comitês para a discussão de assuntos políticos na região. Nesse ano, começou a criar, em Rojava e em outras partes da Síria onde havia apoio da população curda, conselhos autônomos independentes de partidos. Com isso, o movimento poderia começar a implementar a Autonomia Democrática - a autonomia da comuna. (KNAPP, FLACH; AYBOGA, 2016, p. 86) “Em pouco mais de um ano, de março de 2011 a 19 de julho de 2012, Rojava estabeleceu sua nova ordem social de democracia direta". ${ }^{5}$ (KNAPP; FLACH; AYBOGA, 2016, p. 86, tradução nossa)

Opondo-se à organização nos moldes do Estado nacional, os curdos de Rojava aproveitaram o contexto da guerra civil síria para lutar por sua independência. Contudo, o projeto revolucionário em marcha nesse conjunto de três cantões não se restringe à defesa da independência do povo curdo. Ele busca pôr em prática uma nova forma de organização humana.

Embora os preceitos do Confederalismo Democrático sejam propostas a serem defendidas pelo PKK em todas as regiões em que ele se encontra, é em Rojava que eles estão sendo postos em prática pela primeira vez. Mesmo que o PKK proclame uma política de neutralidade e equidade de gênero, em lugares como o Curdistão iraquiano as guerrilheiras mulheres têm um papel muito mais diminuto e recebem muito menos reconhecimento do que as suas análogas na Síria e na Turquia. (SZANTO, 2016, p. 308)

4 Não se sabe precisamente o quanto o PKK continua envolvido nas atividades do PYD e do YPG, mas as organizações compartilham os mesmos objetivos e valores. (MOGELSON, 2017)

5 'In just over a year, from March 2011 to July 19, 2012, Rojava had established its new direct-democratic social order". 


\section{Rojava aparece para o mundo}

A presença de mulheres na linha de frente do combate ao Estado Islâmico despertou a atenção do mundo para Rojava. Para visitantes ocidentais simpáticos às ideias de Öcalan, Rojava é um lugar em que as sementes da Primavera Árabe prometem florescer em uma utopia secular. (ENZINNA, 2015) A quebra do paradigma militar tradicional, no qual as mulheres são apenas espectadoras e vítimas dos conflitos armados, é objeto de fascínio da mídia ocidental.

Quando o cerco de Kobanî por parte do Estado Islâmico começou, em setembro de 2014, imagens de mulheres curdas lutando contra a força eminentemente machista do Estado Islâmico circularam ao redor do mundo nas primeiras páginas dos jornais. (SZANTO, 2014, p. 306) Enquanto os protestantes da Síria eram retratados como fugitivos da opressão governamental, as mulheres curdas eram retratadas como fugitivas da subjugação dos homens islamitas. (SZANTO, 2016, p. 308)

Em setembro de 2014, a revista Marie Claire publicou, em seu website, um ensaio fotográfico com as mulheres do YPJ (Unidade de Proteção das Mulheres) em Rojava, caracterizando-as como "fortes", "destemidas" e "disciplinadas". Segundo a matéria, "elas lutam com armas que são maiores e mais pesadas que elas contra um inimigo implacável. E mesmo assim elas continuam a lutar". (GRIFFIN, 2014) Trazendo relatos coletados pelo fotógrafo da revista, a matéria enfatiza o caráter feminista da luta das mulheres curdas, ao mesmo tempo em que se preocupa em rivalizá-las com o governo sírio ${ }^{6}$ Também ressaltando o protagonismo feminino em Rojava, a revista Vice publicou, em outubro de 2013, uma matéria em que apresenta as "mulheres combatentes da liberdade7 da Síria". (JOHNSON, 2013) Mais tarde, em julho de 2017, a revista publicou uma

6 Embora os curdos da Síria tenham sido historicamente reprimidos nos governos de Hafez e seu filho Bashar Al-Assad (COUNCIL ON FOREIGN RELATIONS, 2017), as relações entre Rojava e Damasco são atualmente mornas, diante da guerra civil que assola o país. Pode-se inferir que os combatentes de Rojava são, em alguma medida, úteis ao governo sírio pois os mesmos lutam contra ataques externos ao país. Por conta disso, foram acusados de se aliar secretamente ao governo de Assad. (KNAPP; FLACH;AYBOGA, 2016, p. 50)

Freedom fighters, no original em inglês. 
reportagem intitulada "A revolução mais feminista que o mundo já testemunhou” (VICE, 2017), na qual louva o caráter igualitário do projeto democrático de Rojava e ressalta a sua importância para o ocidente.

\begin{abstract}
Ainda assim, as hipócritas manobras geopolíticas internacionais não devem obscurecer a importância da revolução democrática de Rojava. Graças a táticas horríveis, o ISIS atrai mais atenção, mas o fato é que Rojava carrega uma mensagem política mais importante para aqueles que se importam com a democracia. Rojava oferece uma alternativa e um exemplo prático onde as pessoas estão no comando, e isso funciona. [...] Enquanto isso, o modelo de Rojava não é menos relevante para o ocidente, onde pouca gente pode dizer que a democracia vai muito bem, com desilusão e extremismo reacionário - e mesmo hostilidade aberta contra mulheres (expressada não apenas por Donald Trump) - estão em ascensão. (VICE, 2017)
\end{abstract}

Em um artigo de opinião publicado no The New York Times em agosto de 2016, Meredith Tax (2016b) ilustra o fascínio midiático pelas guerrilheiras curdas quando afirma que "é a mulher guerreira em particular que oferece uma poderosa contra imagem à da vítima estuprada e desonrada que é considerada uma fonte de vergonha para sua família e comunidade". (TAX, 2016b, tradução nossa) Em reportagem em outubro de 2017, a CNN traz fotos de guerrilheiras curdas sorridentes e falas em que elas afirmam sua intenção em lutar pela "liberação mental" das pessoas e contra a "mentalidade chauvinista contra as mulheres". (BALKIZ; DEWAN, 2017)

Em 2018, a exaltação das combatentes curdas ganhou um novo capítulo. Em janeiro, a jornalista francesa Caroline Fourest anunciou que dirigirá um filme inspirado nas mulheres que se voluntariam para ajudar a luta curda - síria e iraquiana - contra o Estado Islâmico. (KESLASSY, 2018) Segundo Fourest, a ideia é fazer um filme político com personagens femininas fortes, cenas de ação e um elemento de vitória que seja universal o suficiente para atingir o público internacional. (KESLASSY, 2018)

Tal celebração da agência feminina é uma das típicas formas gendradas pelas quais as mulheres árabes ou muçulmanas são retratadas pela 
mídia anglófona. Segundo Mohja Kahf (2000 apud SZANTO, 2014), essas mulheres normalmente são classificadas de três diferentes formas: como vítimas, como fugitivas, ou como “peões do patriarcado". Para Kahf (2000), essas categorias limitadas e enviesadas obscurecem a complexa relação que essas mulheres têm com os homens e camuflam o status socioeconômico das pessoas retratadas (KAHF, 2000 apud SZANTO, 2014, p. 307). No contexto do Curdistão, por exemplo, são as classes trabalhadoras e os pobres que tomam parte na "luta pela liberdade". Por conta disso, existem mais mulheres combatentes no Curdistão Sírio - mais pobre - do que em outras partes do Curdistão (SZANTO, 2014, p. 309).

"As batalhas travadas pelas guerrilheiras curdas na segunda metade de 2014 colocaram em evidência algo que o mundo Ocidental pensou ser impossível: uma sociedade do Oriente Médio com mulheres em seu centro". (KNAPP; FLACH; AYBOGA, 2016, p. 61) Com a resistência de Kobanî, a região, universalmente vista como patriarcal e atrasada, teve sua imagem radicalmente transformada pelas mulheres curdas (KNAPP; FLACH; AYBOGA, 2016, p. 61). A existência de forças femininas salienta, aos olhos do público global, o caráter progressista da Autonomia Democrática e tem contribuído para a solidariedade internacional com a luta dessas mulheres (KNAPP; FLACH; AYBOGA, 2016, p. 159)

O mundo inteiro está falando sobre nós, mulheres curdas. Tornou-se um fenômeno comum para encontrar notícias sobre mulheres lutadoras em revistas, jornais e veículos de notícias. [...] O mundo está espantado com essas mulheres que lutam contra os homens que querem pintar as cores do Oriente Médio de preto e se perguntam de onde elas tiram coragem e como podem rir tão sinceramente. E eu me pergunto sobre eles. Estou surpresa em como eles nos notaram tão tarde, em como não nos conheciam antes. ${ }^{8}$ (DIYAR, 2015, p. 75, tradução nossa)

8 "The whole world is talking about us, Kurdish women. It has become a common phenomenon to come across News about women fighters in magazines, papers, and news outlets [...] The world is amazed by these women who fight against the men that want to paint the colors of the Middle East black, and wonder where they get their courage from, how they can laugh so sincerely. And I wonder about them. I am surprised at how they noticed us so late, at how they never knew of us before." 
A luta das mulheres curdas pela liberação de seu povo não é, portanto, um fenômeno novo. Mulheres curdas lutam há décadas pela independência do seu povo, cuja história contém muitos exemplos de mulheres guerreiras ou líderes. Entre os curdos, as guerreiras mulheres são um elemento persistente de sua identidade. (DIRIK, 2014) Segundo a ativista turca Dilar Dirik (2014), a mídia ocidental, preocupada em retratar como as mulheres curdas desafiam as noções preconcebidas das mulheres orientais como vítimas oprimidas, reproduz caricaturas orientalistas que minimizam sua luta. Com isso, simplificam as razões que motivam essas mulheres a se juntarem à luta. Retratadas apenas como inimigas do ISIS, sua ideologia e objetivos políticos são deixados em segundo plano. (DIRIK, 2014)

Deforma semelhante a Dirik, a ativista síria-palestina Razan Ghazzawi critica o uso da "guerra ao terror" como instrumento de libertação das mulheres. Segundo ela, sugerir que revoluções sexuais e de gênero estão sendo realizadas através da associação a um partido autoritário (o PYD) apaga outras lutas locais e reproduz um discurso colonial de superioridade cultural. (GHAZZAWI, 2017) Assim como aconteceu na "guerra ao terror" após o 11 de setembro, a cobertura da mídia ocidental sobre a revolução de Rojava mobiliza símbolos do feminismo para fortalecer a imagem de uma organização política progressista.

Em julho de 2017, a cobertura midiática da região passou a alardear um fenômeno inédito: a criação de um exército LGBTQ, o TQILA, sob o guarda-chuva das Forças de Guerrilha Populares Internacionais Revolucionárias (IRGF), que lutam ao lado das forças do YPG (Unidades de Defesa do Povo), do PYD. Segundo o grupo, o objetivo da luta é acabar com o binarismo de gênero e avançar na revolução social. (GHAZZAWI, 2017) A notícia despertou dúvidas acerca da autenticidade do grupo,

9 A "guerra ao terror" é um termo usado para descrever a campanha multidimensional de combate ao terrorismo liderada pelos Estados Unidos, lançada em resposta aos atentados terroristas de 11 de setembro de 2001. De alcance quase ilimitado, seu impacto nas relações internacionais é comparável ao da Guerra Fria. (JACKSON, 2018) Ela motivou a invasão do Afeganistão, em 2001, e do Iraque, em 2003, pelos Estados Unidos. No Afeganistão, uma das justificativas para a invasão foi a liberação das mulheres afegãs do regime opressor do Talibã. (ABU-LUGHOD, 2012) Aqui, utilizo aspas para indicar que seu escopo não se limitou ao combate ao terrorismo. 
assim como questionamentos sobre a qualificação dos seus guerrilheiros. Alguns ainda questionaram se a criação do grupo seria uma estratégia do YPG de ganhar cobertura favorável da mídia ocidental. De fato, muitas personalidades da esquerda progressista ocidental celebraram a criação do grupo como "vingança queer contra o ISIS" (GHAZZAWI, 2017). Mas, como chama atenção Ghazzawi, o que faltou no debate é a forma como o discurso do grupo faz do discurso da "guerra ao terror" um método "revolucionário" de alcançar a justiça social universal nas linhas de frente da Síria. (GHAZZAWI, 2017)

A literatura decolonial traz ainda para a reflexão o fato de que a "guerra ao terror" é um projeto de cunho eminentemente imperialista, relacionado à propagação de narrativas de salvamento em relação às mulheres muçulmanas. Tal narrativa não é uma ferramenta exclusivamente de potências ocidentais, tendo sido usado por muitos Estados anti-imperialistas no Oriente Médio para reprimir a oposição e os direitos das minorias. (GHAZAAWI, 2017) Como lembra Lila Abu-Lughod (2012), "uma das coisas a respeito das quais devemos ser mais cuidadosos ao pensar nas feministas do Terceiro Mundo e no feminismo em diferentes partes do mundo muçulmano é como não cair em polarizações que colocam o feminismo do lado do Ocidente". (ABU-LUGHOD, 2012, p. 463)

O cuidado com a retórica salvacionista parece ser necessário não apenas para as mulheres e feministas ocidentais. De fato, é possível perceber, em alguns pronunciamentos de curdas sobre outras mulheres da região, a presença do elemento de salvação. Temendo que a "Primavera Curda" tenha o mesmo fim dos outros movimentos da região, que acabaram por não resultar no reconhecimento dos direitos das mulheres, a chefe da Associação de Mulheres Sírias, Zîhan Davut, diz que “[...] em Rojava é difícil chegar às mulheres árabes, porque elas não conhecem seus direitos. Só para ir a uma reunião, elas precisam da permissão dos seus maridos. Mas nós estamos gradualmente estabelecendo contato com elas". ${ }^{10}$ (KNAPP, FLACH; AYBOGA, 2016, p. 73, tradução nossa) Para a combatente Avril

10 “Here in Rojava it's difficult to reach the Arab women, because they don't know their rights. Just to go to a meeting, they have to get permission from their husbands. But we're gradually building contacts with them." 
Difram, de 20 anos, que luta no YPJ há 3 anos, "as mulheres são especialmente oprimidas pelo Estado Islâmico em Raqqa. Esse é outro motivo pelo qual nós lutamos contra o ISIS - nós queremos libertar as mulheres da opressão". (BALKIZ.; DEWAN, 2017)

Despertando o interesse da mídia internacional como um fenômeno intrigante ou mesmo paradoxal - já que a maior parte das suas defensoras é muçulmana -, o movimento das mulheres curdas nasceu e se desenvolve no contexto da luta pela independência do povo curdo. A despeito da visão orientalista com a qual têm sido noticiados os acontecimentos em Rojava, a defesa da libertação das mulheres curdas é indissociável do desenvolvimento do PKK, considerado como uma organização terrorista pela Turquia e por diversos países ocidentais, como os Estados Unidos.

\section{O PKK e a igualdade de gênero}

Em 1978, com a criação do PKK, a questão da dominação masculina já estava em voga. Mas foi somente com o aumento da participação de mulheres na luta armada pela independência do povo curdo que essa se tornou uma prioridade política. Nesse sentido, o papel de Öcalan foi fundamental para a inserção da pauta de libertação feminina dentro do partido, encontrando resistência por parte de alguns de seus membros masculinos. (GÜNEŞER, 2015)

Nos anos 1980, as atividades do movimento curdo - que passou a priorizar o problema étnico sobre a defesa do socialismo - fizeram com que as mulheres curdas, acostumadas a ficar em casa e serem subservientes aos seus maridos, reivindicassem seus direitos, lutassem por suas línguas, culturas e identidades. (ÇAHA, 2011, p. 438)

Inicialmente, as mulheres se juntaram às forças guerrilheiras por conta do machismo que enfrentaram nas estruturas tribais feudais, assim como por conta da fúria que sentiam diante da opressão colonialista e exploradora contra os curdos pela República Turca. ${ }^{11}$ (GÜNEŞER, 2015, p. 61, tradução nossa)

11 "Women joined the guerilla forces from the beginning because of the sexism they faced in feudal tribal structures as well as the fury they felt in the face of increasing colonialist and ex- 
A participação das mulheres nas atividades do movimento curdo fez surgir uma consciência individual e fomentou a sua independência. (ÇAHA, 2011, p. 438) Somada a isso, a emergência de um movimento feminista na Turquia, nos anos 1980, inspirou as mulheres curdas a tomarem consciência de seu papel de gênero, a se separarem das organizações masculinas, organizando-se independentemente, e a definir e expressar suas identidades como feministas. (ÇAHA, 2011, p. 439) No entanto, a emergência do ativismo feminino no seio do movimento curdo não se deu sem resistência. Diversas revistas curdas publicadas por mulheres na época ressaltam que a luta pelos direitos das mulheres era constantemente reprimida ou, no mínimo, colocada em segundo plano pelos homens, que argumentavam que as mulheres estavam presentes no movimento curdo por sua identidade curda e não como mulheres. (ÇAHA, 2011, p. 438) Até mesmo a menção à opressão sexista era considerado um luxo, visto que os membros masculinos frequentemente menosprezavam a relevância das questões femininas. (ÇAHA, 2011, p. 438-439)

Não se pode dissociar a mudança ideológica do PKK ao contexto histórico mais amplo. Durante a Guerra Fria, o comunismo empurrava demandas políticas por canais distributivos, emudecendo as questões de reconhecimento, descartadas como questões secundárias dos problemas econômicos "reais". (FRASER, 2007, p. 298) Com o fim do comunismo, no entanto, o igualitarismo econômico foi deslegitimado e novas lutas por reconhecimento - especialmente em relação à nacionalidade e à religião - ganharam espaço. (FRASER, 2007, p. 298)

Quando Öcalan mudou sua orientação ideológica, por volta dos anos 1990, os membros do PKK naturalmente hesitaram em abandonar seu antigo modelo de terrorismo marxista-leninista. No final das contas, entretanto, eles seguiram as ordens de “Apo" (modo como Öcalan é chamado entre seus seguidores). ${ }^{12}$ As lideranças femininas do partido, em particular, abraçaram a nova ideologia. (ENZINNA, 2015)

ploitative oppression against the Kurds by the Turkish Republic. People from all walks of life came to wage a common struggle."

12 É possível que a assimilação do novo caráter do movimento só tenha acontecido devido ao forte culto à figura de Öcalan, que permanece até hoje. 
Embora o pensamento de Öcalan sobre a democracia não tenha florescido até os anos 2000, quando ele começou a reavaliar suas ideias na prisão, sua nova visão já tomava forma em meados dos anos 1990. (TAX, 2016a) Foi durante os anos 1990 que a luta pela liberdade feminina se tornou mais radical, com a introdução, por Öcalan, da ideia de "eliminar o macho dominante". ${ }^{3}$ A partir desse período o movimento curdo passou a discutir como poderia romper, mental e culturalmente, com as formas dominantes da modernidade. (GÜNEŞER, 2015) Paralelamente a esse esforço, o movimento também procurou formular um projeto para "transformar a mentalidade masculina”, objetivo pelo qual as mulheres passaram a educar os homens. (GÜNEŞER, 2015)

A virada ideológica tornou-se explícita na resolução do quinto congresso do partido, em 1995, que revogou decisões políticas feitas do terceiro congresso, em 1986, e reconheceu as mulheres como a força motora da revolução. (TAX, 2016a, p. 105) Meredith Tax (2016a), atribui essa à transformação do PKK de um grupo de militantes focados na luta armada, nos anos 1980, para um movimento de massas, nos anos 1990, que contou com uma grande presença de ativistas mulheres. Ainda, entre 1990 e 1995, enquanto o partido se concentrava em suas lutas internas, os curdos da Turquia passavam por mudanças. As mulheres, em especial, se radicalizaram e se tornaram mais ativas politicamente, aproveitando a oportunidade oferecida pela resistência civil para se libertar dos papeis tradicionais de gênero. (TAX, 2016a, p. 108)

Embora as mulheres curdas estivessem historicamente em desvantagem em relação aos homens, sua participação em movimentos populares nos anos de 1980 e 1990, assim como a ideologia do PKK, permitiu que elas tivessem acesso à educação e fossem valorizadas como parte da luta do povo curdo. (KNAPP; FLACH; AYBOGA, 2016, p. 63) Nos anos 1990,

13 Öcalan associava os traços de personalidade tradicionalmente masculinos à dominação, violência, superioridade e arrogância. Portanto, os homens do PKK precisavam se libertar desse tipo de comportamento e adotar a personalidade do "novo homem", cujas características inspiradas pelas da "mulher livre" - são a paz, a comunicação com a natureza, a cultura, a "socialidade" e um senso de dever patriótico. (GROJEAN, 2014) Para Öcalan, a morte do homem dominante significava a morte da dominação, da desigualdade e da intolerância. (TAX, 2016a, p. 127) 
o PKK encorajava a liberação das mulheres lhes oferecendo educação e criando espaços de participação política para elas. "As mulheres iam de casa em casa, batendo às portas, tentando convencer as mulheres em casa a se juntar ao movimento. Elas regularmente faziam trabalhos educacionais e realizavam assembleias femininas" curdo. (KNAPP; FLACH; AYBOGA, 2016, p. 63)

Porque o PKK era a priori uma organização de guerrilha, a força das vozes femininas esteve intimamente relacionada à força militar das mulheres. (TAX, 2016a, p. 136) No início dos anos 1990, um grande influxo de recrutas mulheres impulsionou a criação das primeiras unidades femininas, em 1993. Essas unidades foram fundamentais em proporcionar às mulheres a confiança e a experiência de liderança necessárias para formarem um exército próprio. (TAX, 2016a, p. 137; GÜNEŞER, 2015) Antes da formação de unidades exclusivamente femininas, as guerrilheiras sofriam de um "complexo de inferioridade", decorrente de seu condicionamento social, que tornava difícil a aceitação de comandantes mulheres tanto por homens como por mulheres. (TAX, 2016a, p. 137)

Em seu quinto congresso, em 1993, o PKK criou um exército feminino conhecido como União das Mulheres Livres do Curdistão (Yekitiya Azadiya Jinen Kurdistan, ou YAJK), cujas guerrilheiras rejeitavam o papel tradicionalmente atribuído às mulheres e assumiam uma nova função como "guerreiras da liberdade", por ter "tanto a ganhar e tão pouco a perder”. (KNAPP; FLACH; AYBOGA, 2016, p. 37) Com o objetivo de superar a socialização tradicional da sociedade feudal que era reproduzida nos exércitos de guerrilha, o YAJK desenvolveu princípios de organização autônoma feminina, dupla liderança e cota mínima de 40\% de participação de mulheres em todas as áreas. Tais princípios guiam o projeto de governo de Rojava nos dias atuais. (KNAPP; FLACH; AYBOGA, 2016, p. 37)

Entre 1993 e 2003, o PKK experimentou um período de transição, no qual se desassociou do marxismo-leninismo e entregou-se à sua busca por estabelecer uma alternativa ao capitalismo moderno. Através de materiais teóricos e da experiência prévia de vários movimentos sociais, como o feminismo, o movimento dos curdos concluiu que a escravidão feminina constitui a base de todas as escravidões subsequentes, assim como de 
todos os problemas sociais. (GÜNEŞER, 2015) Em 1997, cinco mil mulheres lutavam em milícias exclusivamente femininas, com comandantes e planejamentos próprios, e onze mil lutavam nas unidades mistas. (TAX, 2016a, p. 139) Em 2013, as mulheres compunham quase metade dos membros do PKK. (ÇANDAR, 2013)

O destaque feminino na luta curda também é fruto de questões práticas. Entre 2004 e 2012, somente elas poderiam funcionar politicamente, já que os homens que se organizassem eram presos. Com isso, a organização passou a ser um trabalho das mulheres. Isso não impediu, no entanto, que as membras do movimento feminino Kongreya Star (Congresso das Mulheres Livres) fossem presas e torturadas durante o regime de Assad. (KNAPP; FLACH; AYBOGA, 2016)

Na Síria, o acesso à educação impulsionou a ideia de participação feminina como estratégia de luta. Quando a revolução começou, mulheres vieram de diversas partes do Curdistão para apoiá-la, trazendo consigo conhecimento tático de guerra, assim como sua experiência prática e teórica com a Autonomia Democrática. (KNAPP; FLACH; AYBOGA, 2016, p. 64)

É um pressuposto básico do movimento de mulheres curdas a construção de instituições de mulheres em todas as áreas, para que elas possam se libertar intelectualmente, emocionalmente e espiritualmente da autoridade e da violência da dominação patriarcal. (KNAPP; FLACH; AYBOGA, 2016, p. 64, tradução nossa)

Quanto mais o tempo de Öcalan na cadeia passava, mais ele passou a se preocupar com o feminismo. (MOGELSON, 2017) Em 2013, escreveu um manifesto chamado Liberating Life (ÖCALAN, 2015), no qual escreve que a história de 5 mil anos de civilização é, em essência, a história da escravidão das mulheres, e argumenta que não pode haver nenhuma emancipação política genuína sem primeiro se alcançar a igualdade de gênero. (ÖCALAN, 2014 apud MOGELSON, 2017). 


\section{Uma revolução feminina e feminista}

O movimento das mulheres curdas busca superar a alienação das mulheres curdas - isso é, a depreciação colonialista de sua cultura. Ele busca assegurar que elas sejam responsáveis por suas próprias vidas e capazes de tomar suas próprias decisões. (KNAPP; FLACH; AYBOGA, 2016, p. 63, tradução nossa)

Em paralelo à luta existencial contra o ISIL, as mulheres na região do Curdistão Sírio, incluindo árabes, assírias, turcas e armênias, lideram uma revolução social contra a ordem patriarcal da sociedade através de uma governança igualitária de gênero e um movimento feminista popular. (DIRIK, 2014, tradução nossa)

A revolução em andamento em Rojava é uma revolução de mulheres. A ideia de que as mulheres seriam a ponta-de-lança da revolução tem grande aceitação na região. (KNAPP; FLACH; AYBOGA, 2016, p. 63) Não só sua filosofia tem traços caracteristicamente feministas, como o próprio desenvolvimento político da região é diretamente influenciado por mulheres no poder. Em Rojava, o princípio de dupla liderança, segundo o qual qualquer liderança política deve ser composta de duas pessoas, das quais pelo menos uma mulher, é aplicado em todo lugar. (KNAPP; FLACH; AYBOGA, 2016, p. 64) O PYD encoraja as mulheres a participar da luta através da Unidade de Defesa das Mulheres (Yekîneyên Parastina Jin, ou YPJ), organização militar de autodefesa exclusivamente feminina, fundada em 2013. Além de lutarem contra o regime de Bashar Al-Assad e o ISIS, na Síria, as mulheres curdas lutam contra regimes que elas consideram opressores, como o da Turquia e o do Irã.

O objetivo primordial do movimento de mulheres, a Kongreya Star, é educar politicamente toda a sociedade. Portanto, suas membras fazem visitas periódicas a residências de seus bairros, sejam elas de famílias curdas ou não, para explicar a agenda da revolução e distribuir um jornal semanal escrito em curdo e em árabe. Ainda, a região conta com tribunais locais especializados em questões femininas, como violência doméstica e pensão alimentícia. (KNAPP; FLACH; AYBOGA, 2016, p. 66) 
Tanto entusiasmo pela libertação das mulheres do patriarcado não significa, no entanto, que as mulheres curdas em Rojava não sejam mais sujeitas à opressão. Como curdas, elas tiveram e ainda têm negados direitos básicos e, como mulheres, ainda são sujeitas à dominação patriarcal. (KNAPP; FLACH; AYBOGA, 2016, p. 62) “A despeito do legado das guerreiras curdas, seria um exagero dizer que a sociedade curda tem uma igualdade de gênero, considerando a prevalência do domínio e da violência masculinos". (DIRIK, 2014, tradução minha) Em relação à luta armada, por exemplo, um obstáculo à participação feminina é a restrição do alistamento às mulheres jovens e solteiras. Tais exigências são estipuladas pelo PYD, que busca garantir a honra e a pureza sexual das combatentes. ${ }^{14}$ (SZANTO, 2016; TAX, 2016a) O fato de uma mulher ter filhos ou ter tido muitos familiares martirizados também costuma ser impeditivo para a sua entrada na luta armada. (KNAPP; FLACH; AYBOGA, 2016, p. 151)

Estariam, portanto, as mulheres curdas apenas fugindo momentaneamente do patriarcado, e não o combatendo? (SZANTO, 2016) Mesmo se esse for o caso, é improvável que as ideias que ecoam em Rojava atualmente não provoquem nenhuma mudança na organização das sociedades curda e síria.

\section{$\mathrm{O}(\mathrm{s})$ feminismo(s) curdo(s)}

Sem a repressão das mulheres, a repressão de toda a sociedade não é concebível. O sexismo na sociedade do Estado nacional, enquanto, por um lado, dá ao macho o máximo poder, por outro lado, por meio da mulher, transforma a sociedade na pior de todas as colônias. Por conseguinte, a mulher é parte da nação colonial da sociedade histórica, e alcançou sua pior posição dentro do Estado nacional. Todo o poder e todas as ideologias estatais de-

14 A exigência do celibato para a luta é originária do PKK, que considerava a entrada no partido análoga ao compromisso do casamento. Além da dedicação exclusiva às atividades do partido, o PKK também proibia seus membros de consumir álcool e drogas e exigia o rompimento de laços familiares. O sacrifício pessoal completo era considerado necessário para que os membros do partido se tornassem "novos homens" e "mulheres livres". (TAX, 2016a, p. 127) 
correm das atitudes e dos comportamentos sexistas. A escravidão da mulher é a mais profunda e disfarçada área social onde todos os tipos de escravidão, opressão e colonização são realizados. O capitalismo e o Estado nacional agem com plena consciência disso. Sem a escravidão da mulher, nenhum dos outros tipos de escravidão pode subsistir e muito menos se desenvolver. Capitalismo e Estado nacional significam o mais institucionalizado macho dominante. Mais vigorosa e abertamente falando: o capitalismo e o Estado nacional são o monopólio do macho despótico e explorador. (ÖCALAN, 2015, p. 121)

Não somos soldados, somos militantes; não somos pagas para fazer a guerra, somos partidárias da revolução. Vivemos com nosso pessoal, seguimos uma filosofia e temos um projeto político. Ao mesmo tempo, estamos realizando uma luta de gênero contra o sistema patriarcal [...] - Nesrin Abdullah, comandante do YPJ.15 (SGRENA, 2015, tradução nossa)

Não é possível entender o feminismo do movimento das mulheres curdas sem primeiro contextualizá-lo. Segundo Omer Çaha (2011), que analisou os movimentos de mulheres curdas na Turquia nos anos 1980 e 1990, a característica distintiva do feminismo curdo é o fato de que as mulheres curdas sempre se apresentaram com detentoras de uma dupla identidade, argumentando que não são somente mulheres, mas também membras da nação curda. (ÇAHA, 2011, p. 445) Historicamente, as mulheres curdas lutaram pela independência de seu povo, e essa luta gradualmente se voltou para a causa feminista e permitiu que elas se tornassem protagonistas do movimento. Ainda, a participação na luta armada é relacionada à situação econômica das mulheres. As mulheres de famílias pobres são mais inclinadas a se tornarem guerrilheiras, e o Curdistão Sírio é mais pobre do que outras partes do Curdistão. (SZANTO, 2016, p. 309) Isso ajuda a explicar porque, mesmo com libertação feminina sendo parte da ideologia do PKK, o Curdistão sírio conta com mais combatentes

"We are not soldiers, we are militants; we are not paid to make war, we are partisans of revolution. We live with our people, follow a philosophy and have a political project. At the same time we are carrying out a gender struggle against the patriarchal system [...]". 
mulheres do que, por exemplo, o Curdistão iraquiano. (SZANTO, 2016, p. 309) Em Rojava, as mulheres curdas se juntam à luta armada porque entendem que a mesma lhes oferece a possibilidade de alcançar a liberdade e a igualdade em relação aos homens. (DÜZGÜN, 2016, p. 284) Nesse sentido, é necessário situar de que liberdade e de que igualdade elas estão falando.

\section{Origens do feminismo curdo}

Apesar de terem se inspirado, nos anos 1980, no feminismo que emergiu na Turquia, adotando as ideias características do feminismo liberal de segunda onda - "o pessoal é político" e defesa da sororidade entre mulheres (BELGIN, 2000 apud ÇAHA, 2011, p. 439) -, as mulheres curdas criticavam o movimento feminista turco por ignorar seus problemas subjetivos sob uma abordagem universalista do feminismo. (ÇAHA, 2011, p. 439) Frequentemente, ao expressarem demandas de cunho étnico, as mulheres curdas eram acusadas de contaminar o movimento feminista com ideias nacionalistas. (ÇAHA, 2011, p. 439) O clímax dos eventos que separaram as mulheres curdas de outras feministas - e que as impulsionou a formar outra organização -, ocorreu em 1989, durante as celebrações do Dia Internacional da Mulher, quando a intenção de um grupo de mulheres curdas de carregar cartazes e de se pronunciar em curdo foi rechaçada pelo comitê organizador. A partir daí, feministas curdas e turcas passaram a seguir caminhos independentes e, em 1990, foi formado o Grupo de Mulheres Curdas independente. (ÇAHA, 2011, p. 439)

Em 1996, foi lançada a primeira revista de mulheres curdas explicitamente feminista, Roza, que teve 17 edições publicadas, até o início dos anos 2000. (ÇAHA, 2011, p. 439) Seu nome era uma homenagem a Rosa Luxemburgo, uma das primeiras militantes marxistas e cuja opressão derivada de sua situação de dupla identidade (como "mulher" e como “judia”) era considerada análoga à das mulheres curdas, oprimidas e alienadas por serem "mulheres" e "curdas". (YAŞAR, 1996 apud ÇAHA, 2011, p. 439) "As mulheres que publicavam a Roza argumentam que elas eram excluídas pelos grupos feministas turcos por serem curdas e pelo 
movimento político curdo por serem feministas”. ${ }^{16}$ (AYŞEGÜL, 1996 apud ÇAHA, 2011, p. 440, grifo do autor, tradução nossa) Tal problema pode ser entendido pelo que Kimberlé Crenshaw (1989) denomina "enquadramento de eixo único" e se traduz pela tendência a tratar raça e gênero como categorias mutuamente excludentes. (CRENSHAW, 1989)

Analisando alguns casos da jurisprudência americana para entender como as cortes enquadram e interpretam as histórias das mulheres negras, Crenshaw (1989) argumenta que as mulheres negras dos Estados Unidos são frequentemente forçadas a reivindicar seus direitos ou em termos de sua raça ou de seu gênero. No entanto, suas experiências são muito mais amplas do que as categorias gerais que o discurso da discriminação fornece e, por conta disso, as mulheres negras são frequentemente excluídas da teoria feminista e do discurso político antirracista, visto que ambos se baseiam em um conjunto de experiências - a da mulher branca e a do homem negro - que não refletem apropriadamente a interação entre raça e gênero. Segundo Crenshaw (1989), a relutância em aceitar a especificidade da discriminação das mulheres negras não é uma questão de vontade política mas reflete a limitação das formas dominantes de pensar a discriminação. Por isso, ela defende uma abordagem que denominou "interseccionalidade", que argumenta que as pessoas sofrem diferentes tipos de opressão ao mesmo tempo, que se combinam em problemas específicos e não traduzíveis pela mera inclusão de um grupo de mulheres (ex: mulheres curdas) em uma estrutura analítica já estabelecida. É necessário, portanto, pensar nas opressões de raça, gênero, classe, etc. não como mutuamente excludentes mas sim como fatores que se unem em opressões específicas. ${ }^{17}$ (CRENSHAW, 1989)

16 "The women who were publishing Roza argue that they are excluded by Turkish feminist groups since they are Kurdish and they are also excluded by the Kurdish political movement since they are feminists."

17 Embora Crenshaw seja apontada como a primeira teórica a articular a compreensão de opressões diferentes em torno do conceito de "interseccionalidade", outras feministas anteriores já destacavam a necessidade de se pensar em opressões específicas em termos conjuntos de classe e raça. A brasileira Lélia Gonzalez (1984), por exemplo, critica o mito da democracia racial no país e expõe as formas como raça, classe e gênero se interlaçam na produção de subjetividades como a da "mulata", da "mucama permitida" e da "mãe-preta" (GONZÁLEZ, 1984). 
O problema de reconhecimento de identidades exemplificado pelas mulheres curdas e pelas mulheres negras é característico do movimento feminista dos anos 1980. Tradicionalmente, a historiografia dos feminismos divide o movimento em três fases, ou ondas. ${ }^{18}$ A primeira onda, nos séculos XIX e início do XX, é caracterizada pelo surgimento do feminismo liberal na Inglaterra e na França, ${ }^{19}$ que, exemplificado pelo movimento das sufragettes, reivindicava o direito ao voto, à participação política, à participação no mercado de trabalho e o divórcio. A segunda onda, cuja expressão maior é a do movimento das donas de casa dos Estados Unidos, ${ }^{20} \mathrm{se}$ deu nos anos 1960 e 1970 e reivindicava direitos reprodutivos e de participação no mercado de trabalho. A terceira onda, nos anos 1980 e 1990, é caracterizada pela radicalização do debate identitário, pela contestação da universalidade das pautas anteriores e pelo desenvolvimento acadêmico dos feminismos. Não obstante essa historiografia tradicional, opto aqui pela periodização segundo Nancy Fraser ${ }^{21}$, que divide a história dos movimentos feministas em duas ondas - a segunda com três fases distintas.

Segundo Fraser (2007, p. 292-293)

18 Nem o número de ondas e nem a classificação do feminismo dessa forma são consenso entre as feministas. Dentre os diversos argumentos que contestam essa divisão, destaca-se a objeção ao seu caráter anglocêntrico e teleológico. A narrativa sobre a primeira onda, por exemplo, costuma excluir os feminismos comunista e anarquistas, que tinham pautas revolucionárias e não reformistas, como o direito ao voto. A divisão em ondas também pode dar a impressão de que não houve mobilização em outras épocas ou que só as mobilizações que se encaixam nelas foram legítimas. Ainda, é importante ressaltar que diferentes ondas coexistiram no espaço e no tempo - o feminismo negro, por exemplo, existe desde o século XIX. (HOOKS, 2015). Por fim, não existe consenso acerca de quantas ondas existiriam. Algumas feministas falam de duas (Fraser), três ou até mesmo quatro (sendo a quarta caracterizada pela mobilização através de redes sociais na internet).

19 São características dessa onda as obras de Mary Wollstonecraft e Olympe de Gouges, que dialogam com a Revolução Francesa e, no Brasil, Bertha Lutz. Por vezes também são atribuídos a esse grupo os trabalhos de Simone de Beauvoir (1949) e Margareth Mead (1935).

20 Betty Friedan (1963) costuma ser apontada como maior símbolo do feminismo liberal dos anos 1960 .

21 Embora Fraser não adote a perspectiva pós-colonial, que seria mais adequada para o objeto de estudo em questão, sua periodização logra em articular as mudanças interiores do movimento em relação aos desenvolvimentos históricos mais amplos, resultando em uma narrativa mais histórica e menos autocongratulatória. (FRASER, 2007, p. 292) 
a história da segunda onda do feminismo se divide em três fases. Em uma primeira fase, o feminismo estava estritamente relacionado a vários 'novos movimentos sociais' que emergiram do fermento dos anos 60. Na segunda fase, foi atraído para a órbita da política de identidades. E, finalmente, em uma terceira fase, o feminismo é cada vez mais praticado como política transnacional, em espaços transnacionais emergentes.

Dessa forma, na primeira fase da segunda onda, os feminismos expuseram o androcentrismo da sociedade capitalista e politizaram o "pessoal”. Na segunda fase da segunda onda, os feminismos se preocuparam com a cultura e foram atraído para a órbita da política de identidade, em um contexto histórico de esgarçamento da democracia social baseada na ideia de nação graças à pressão do neoliberalismo global .(FRASER, 2007, p. 293) Nessa época, os feminismos reinventaram-se como política de reconhecimento e buscaram a autonomização do projeto cultural (ou seja, seu apartamento do projeto de transformação político econômica e de justiça distributiva). (FRASER, 2007, p. 296) Nesse contexto, a imaginação feminista deslocou o imaginário socialista e "a tendência foi de subordinar lutas sociais às lutas culturais, a política de redistribuição à política do reconhecimento". (FRASER, 2007, p. 297)

No contexto das mulheres curdas, os anos 1980 foram caracterizados pela inspiração do movimento feminista turco e o simultâneo tensionamento com o mesmo, resultado do reconhecimento da necessidade de um feminismo mais específico cultural e etnicamente. (ÇAHA, 2011) Nos anos 1990, o movimento foi impulsionado pela mudança de orientação ideológica do PKK, que se distanciou da luta revolucionária. Nessa época, a crítica em relação ao que era percebido como essencialismo do feminismo turco fazia com que feministas curdas acusassem suas contrapartes turcas de racistas e de colonialistas. (SEMA, 1998 apud ÇAHA, 2011, p. 444) Apesar de se posicionarem junto às feministas do mainstream em relação a questões como equidade de gênero, consciência e emancipação feminina, as mulheres curdas contestavam a ideia de "mulher" com um sujeito singular, em oposição ao "homem”. (ÇAHA, 2011, p. 443) A dupla opressão enfrentada pelas mulheres curdas era enfatizada, 
especialmente diante da constatação de que a maior parte das vítimas dos conflitos decorrentes da luta pela independência do povo curdo é de mulheres. (ÇAHA, 2011, p. 441)

As revistas feministas curdas criticavam não somente o Estado turco, sob a perspectiva da questão étnica, mas também condenavam a estrutura tradicional da sociedade curda, seus valores socioculturais - considerados responsáveis pela opressão das mulheres - e o movimento político curdo. (ÇAHA, 2011, p. 443) Elas teciam duras críticas aos homens curdos, considerados machistas. (ÇAHA, 2011) Essas críticas, aliás, estão presentes entre as mulheres de Rojava nos dias de hoje. Por outro lado, a forte crítica aos combatentes curdos e militantes do movimento, presente nas revistas dos anos 1990 (ÇAHA, 2011), não se reproduz nos pronunciamentos das guerrilheiras do YPJ. Segundo a comandante do YPJ Nesrin Abdullah (A, "Os outros combatentes [do YPG] são nossos camaradas; nós temos relações políticas e de amizade”. ${ }^{22}$ (SGRENA, 2015, tradução nossa). Em entrevista ao The New Yorker (MOGULSON, 2017), a guerrilheira Shilah, relata que o seu ingresso na luta armada e no combate ao ISIS foi, em parte, uma forma de transcender limitações que enfrentaria caso ficasse em casa, subordinada a um marido. No YPG, ela considera que as mulheres têm o direito à opinião e suas vozes são ouvidas: "eles querem te colocar na frente. É possível ter seu próprio lugar”. (MOGULSON, 2017)

\section{As feministas de Rojava}

Diferentemente do feminismo das mulheres curdas na Turquia, dos anos 1980 e 1990, o feminismo de Rojava está fortemente relacionado à defesa das ideias de Öcalan e de seu projeto de Confederalismo Democrático. Um dos principais aspectos de gênero de sua filosofia diz respeito à jinealogia. Em seus escritos, Öcalan propõe uma nova abordagem sociológica como estratégia contra a ciência moderna hegemônica, dominada pelo sexismo. A jinealogia - termo que deriva da junção entre a palavra curda para mulher, jin, e logy, do termo grego logos, ou conhecimento - seria uma

22 "Other combatants are our comrades; we have political and friendly relations". (SGRENA, 2015) 
"ciência das mulheres", na qual seria baseada a "sociologia da liberdade", nova forma de aplicar as ciências sociais. (KAYA, 2015)

Partindo de uma crítica ao universalismo positivista, a jinealogia pretende revelar a "verdadeira natureza" da sociedade histórica, marcada pelo protagonismo do corpo feminino. (KAYA, 2015) Nessa perspectiva, enfatiza-se a "sociedade natural", que teria sido construída por mulheres, e busca-se superar a visão da mulher como objeto da história. Ela é encarada simultaneamente como epistemologia e "solução para os maiores paradoxos da nossa época". (KAYA, 2015, p. 91) Considerada como um resultado e uma continuação das experiências e dos esforços feministas, seu objetivo é "andar sobre os trilhos das experiências dos movimentos de mulheres". (KAYA, 2015, p. 92) Ainda, a jinealogia pretende investigar a "colonização histórica das mulheres" e, para isso, almeja reescrever a história da humanidade. (KAYA, 2015, p. 92)

Se, historicamente, a identidade feminista curda foi construída na interseção entre a opressão de nacionalidade e de gênero (ÇAHA, 2011), atualmente, as mulheres curdas de Rojava enfatizam a universalidade de sua luta contra o patriarcado e o Estado-nação - dois elementos entendidos como indissociáveis. Nesse sentido, o feminismo de Rojava pode ser entendido como exemplo da terceira fase da segunda onda dos feminismos, como posto por Fraser (2007). Segundo ela,

Atualmente, muitas feministas transnacionais rejeitam o quadro do Estado territorial. Elas percebem que decisões tomadas dentro de um território frequentemente provocam impacto na vida de mulheres fora dele, assim como o fazem organizações inter e supranacionais, governamentais ou não-governamentais. As feministas também percebem a força da opinião pública transnacional, que flui com supremo desprezo por fronteiras através dos meios de massa globais e da cibertecnologia. Como consequência temos uma nova apreciação do papel das forças transnacionais na manutenção da injustiça de gênero [...]. Sob tais condições, importantes correntes do feminismo estão desafiando o quadro de demandas políticas do Estado territorial. Da forma como elas veem, esse quadro é um grande veículo de injustiça, pois reparte o 
espaço político de maneira a bloquear a contestação, pelas mulheres, das forças que as oprimem. (FRASER, 2007, p. 303-304)

Apesar do feminismo curdo de Rojava ser pautado em ideias e ações políticas muito anteriores à Primavera Árabe, não se pode ignorar que o contexto político do momento contribui para a emergência de um senso de urgência no movimento curdo, e no das mulheres curdas em particular. Com isso, configura-se uma janela de oportunidade para a revolução gestada na década anterior. Ainda, a tentativa de conciliação da diversidade étnica em Rojava, juntamente com a proximidade da ameaça de aniquilação pelo Estado Islâmico, proporciona uma aberta no movimento de mulheres curdas em direção a um maior universalismo, o que pode ser percebido em falas como a da guerrilheira Evin Ahmed, de 26 anos, membra do YPJ: "Temos de ser livres do governo sírio [...] Precisamos controlar a área sem depender deles. Eles não podem nos proteger do [ISIS], temos que nos proteger [e] nós defendemos a todos... Não importa a raça ou religião"23 (GRIFFIN, 2014, tradução nossa) De forma semelhante, Ali Sher, uma comandante do YPG, proclama: "Não pense que nós estamos lutando por Rojava. Nós não somos soldados - somos revolucionárias”. (MOGELSON, 2017)

De forma geral, a administração de Rojava tem feito esforços visando à ampliação do seu reconhecimento internacional. Nas redes sociais, assim como nos meios de comunicação mais politizados, o YPJ urge por uma "solidariedade internacional" às mulheres da região. Também é notável o fato de que tanto o PYD como o YPG e o YPJ mantêm websites em inglês nos quais publicam pronunciamentos e informam o público internacional acerca dos acontecimentos em Rojava. Ainda, em fevereiro de 2015, o ex-presidente francês François Hollande recebeu uma delegação do PYD, que incluía a presença da comandante do YPJ, Nesrin Abdullah. (LES HEROS..., 2015) Mais do que uma estratégia de angariar apoio

"We have to be free from the Syrian government," says YPJ member, Evin Ahmed, 26 [...] "We need to control the area ourselves without depending on them. They can't protect us from [ISIS], we have to protect us [and] we defend everyone...no matter what race or religion they are." 
internacional, essas ações destacam a "nova apreciação do papel das forças transnacionais na manutenção da injustiça de gênero" (FRASER, 2007, p.303), característica da terceira fase da segunda onda do feminismo.

Embora a maior parte das mulheres curdas seja muçulmana, a religião não parece ser parte importante de sua luta. Na verdade, a religião tem sido um empecilho para o regime de Rojava forjar alianças maiores com comunidades árabes, que sentem que a liberação das mulheres viola princípios religiosos básicos. (GRAEBER, 2015, p. 202)

Os desafios em torno da inclusão das mulheres árabes no movimento revolucionário apontam para a questão mais ampla, dentro dos feminismos, da subjetividade na relação das mulheres com a religião. Nesse ponto, Lila Abu-Lughod (2012) oferece uma contribuição interessante. Ao indagar sobre a possibilidade de uma liberação que seja islâmica, ela pergunta:

[...] será a liberação realmente um objetivo pelo qual todas as mulheres ou o povo se esforçam? Emancipação, igualdade e direitos são parte de uma linguagem universal que nós devemos usar? Em outras palavras, poderiam outros desejos ser mais significativos para diferentes grupos de pessoas? Viver em famílias unidas? Viver próximo de Deus? Viver sem guerra? (ABU-LUGHOD, 2012, p. 464)

Como aponta Saba Mahmood (2001 apud ABU-LUGHOD, 2012, p. 464), "o desejo pela liberdade e liberação é um desejo historicamente situado". A dificuldade de conciliação entre mulheres curdas e árabes aponta para uma divergência mais profunda na própria concepção de liberdade. Enquanto que, para as mulheres árabes, a religião é uma parte importante da vida, as mulheres curdas - ou pelo menos as mulheres curdas que estão na linha de frente da revolução - associam a liberdade ao direito à lutar pela sua vida. Essa ideia é expressa pela General Zelal, um dos líderes do YPJ, em entrevista publicada na Marie Claire (GRIFFIN, 2014): "Eu não quero me casar ou ter filhos ou ficar em casa o dia todo. Quero ser livre. Se eu não pudesse ser uma YPJ, acho que meu espírito morreria. Ser 
combatente do YPJ significa ser livre - é isso que significa ser verdadeiramente livre". ${ }^{24}$ (GRIFFIN, 2014, tradução nossa)

Para as mulheres do YPJ, portanto, a impossibilidade de casar ou ter filhos não significa o tolhimento de suas liberdades. Segundo a militante Ali Sher (MOGELSON, 2017), o casamento permite que uma mulher proporcione comida e vestimenta para os seus filhos, mas isso não significa muito pois "até os escravos têm roupas e comida". Segundo ela, quando uma mulher resiste à opressão e à injustiça, ela luta não só pela sua família nuclear, mas pela sua família mais ampla - a sociedade. (MOGELSON, 2017)

Na filosofia de Öcalan, assim como em diversos feminismos, o casamento é uma instituição tão opressora às mulheres que deve ser evitado sempre que possível. (TAX, 2016b) Segundo Öcalan (2014, p. 36, tradução nossa),

O problema mais importante para a liberdade num contexto socialé, portanto, a família e o casamento. Quando a mulher se casa, ela é de fato escravizada. É impossível imaginar outra instituição que escraviza como casamento. As escravidões mais profundas são estabelecidas pela instituição do casamento, escravidões que se tornam mais enraizadas na família [...] O que está em discussão é o casamento e a família clássica arraigada. A propriedade absoluta da mulher significa sua retirada de todas as arenas políticas, intelectuais, sociais e econômicas; isso não pode ser facilmente recuperado. Assim, é necessário rever radicalmente a família e o casamento e desenvolver diretrizes comuns voltadas para a democracia, a liberdade e a igualdade de gênero. ${ }^{25}$

24 "I don't want to get married or have children or be in the house all day. I want to be free. If I couldn't bea YPJ I think my spirit would die. Being a YPJ soldier means being free - this is what it means to truly be free."

"The most important problem for freedom in a social context is thus family and marriage. When the woman marries, she is in fact enslaved. It is impossible to imagine another institution that enslaves like marriage. The most profound slaveries are established by the institution of marriage, slaveries that become more entrenched within the family [...] What is under discussion is the ingrained, classical marriage and family. Absolute ownership of woman means her withdrawal from all political, intellectual, social and economic arenas; this cannot be easily recovered. Thus, there is a need to radically review family and marriage and develop common guidelines aimed at democracy, freedom and gender equality". 
Nesse aspecto, o pensamento de Öcalan encontra semelhança com o feminismo materialista, em especial, com o pensamento de Colette Guillaumin (2014). Segundo Guillaumin (2014), a opressão dos homens sobre as mulheres é caracterizada pela apropriação física das últimas, cujos corpos são apropriados enquanto reservatório de força de trabalho. Nesse tipo de apropriação, que ela denomina como "sexagem", ${ }^{26}$ há uma apropriação física em si, estabelecendo uma “[...] relação na qual éa unidade material produtora de força de trabalho que é tomada em mãos, e não apenas a força de trabalho". (GUILLAUMIN, 2014, p. 34, grifo do autor) Para Guillaumin (2014, p. 39), “o casamento [...] estende o uso físico a todas as formas possíveis dessa utilização, dentre as quais, específica e centralmente (mas não exclusivamente), a relação sexual". Ele é, portanto, “apenas a superfície institucional (contratual) de uma relação generalizada: a apropriação de uma classe sexo pela outra”. (GUILLAUMIN, 2014, p. 50)

O celibato também é uma das regras centrais da guerrilha feminina curda, uma proibição originária do código de conduta do $\mathrm{PKK}^{27}$. Em contraste com a defesa feminista liberal da "liberação sexual", Öcalan argumenta que as relações amorosas pessoais escravizam as mulheres e, portanto, devem esperar até depois da revolução. (ÖCALAN, 2014 apud TAX, 2016a, p. 143)

A repercussão das guerrilheiras curdas nos jornais e até mesmo nas revistas de moda mostra ainda um outro tensionamento com o feminismo liberal, que costuma se opor a discursos e práticas de violência política. (DIRIK, 2017) Segundo Susan Benson-Sokmen (2017), por conta da masculinidade característica da política de guerra, a ideia de que a violência política pode produzir subjetividades femininas outras que não "a vítima" é estranha a muitas feministas ocidentais.

26 Sexage, no original em francês. A palavra tem como objetivo estabelecer uma analogia com os outros tipos de apropriação da força física na economia fundiária: a escravidão (esclavage) e a servidão (servage).

27 O PKK considera que as relações sexuais entre guerrilheiros são uma grave violação do compromisso do partido com a independência e autonomia das mulheres. Nos primeiros tempos de luta, membros que desafiassem essa proibição eram expulsos do partido ou mesmo executados. (TAX, 2016a, p. 143) 
A militarização é, no entanto, parte fundamental do feminismo de Rojava. Para Dilar Dirik (2017), o entendimento do militarismo como um instrumento do patriarcado faz com que sejam pertinentes a crítica feminista liberal do mesmo e a rejeição da participação das mulheres em exércitos convencionais. No entanto, a rejeição completa da violência feminina não permite distinguir o militarismo estatista, colonialista, imperialista e intervencionista da legítima-defesa - vista como necessária. (DIRIK, 2017) Este autor argumenta que é necessário problematizar a noção essencialista de não-violência, que despreza relações interseccionais de poder e mecanismos de violência estrutural. Ao não entender que a inclinação à violência não é específica dos homens, a crítica feminista da violência, apesar de bem-intencionada, pode acabar reproduzindo a visão das mulheres como inerentemente passivas e apolíticas. (DIRIK, 2017)

\section{Conclusão}

O feminismo das guerrilheiras curdas de Rojava não é uma criação dos últimos anos. Ele é tributário da mudança ideológica do PKK nos anos 1990, promovida por Abdullah Öcalan, e do movimento de mulheres curdas, que se desenvolveu no contexto de ascensão do feminismo nos anos 1980, na Turquia. Se, inicialmente, o feminismo curdo se baseava na reivindicação da dupla identidade das mulheres curdas, nos dias de hoje, em Rojava, as pautas feministas são guiadas pelos escritos de Öcalan, que defende um modelo de sociedade radicalmente democrática, cuja territorialidade não seja organizada segundo o modelo do Estado-nação.

Apesar de despertar o fascínio de parte do público ocidental e angariar apoio de setores progressistas de todo o mundo, as mulheres de Rojava também tensionam a narrativa ocidental hegemônica sobre o mundo e os pressupostos feministas liberais. Ainda, ele demonstra a necessidade de uma vigilância constante contra narrativas salvacionistas no feminismo.

O feminismo de Rojava é revolucionário, antimoderno e, apesar de seu forte componente identitário, almeja ser acessível a todas as mulheres. Defendendo o protagonismo das mulheres e a libertação do patriarcado através de meios militares, as feministas de Rojava fornecem uma 
imagem inusitada das mulheres muçulmanas e trazem novos significado para palavras como liberdade, igualdade e emancipação. Com isso, trazem uma forma particular de pensar sobre os feminismos e sobre os meios pelos quais eles se realizam ou devem se realizar, sendo relevante a todas as feministas do mundo.

\section{Referências}

ABU-LUGHOD, L. As mulheres muçulmanas precisam realmente de salvação? Reflexões antropológicas sobre o relativismo cultural e seus Outros. Estudos Feministas, Florianópolis, v. 20, n. 2, p.451-470, maio/ ago. 2012. Disponível em: < http://www.scielo.br/scielo.php?pid=So104026X2012000200006\&script=sci_abstract\&tlng=es $>$. Acesso em: 14 jan. 2018.

AYŞEGÜL. Seni Seviyorum, Roza. Roza, v.3, 1996.

BALKIZ, G.; DEWAN, A. The women fighters who helped defeat ISIS in Raqqa. CNN, Raqqa (Síria), 22 out. 2017. Disponível em: < https://edition. cnn.com/2017/10/20/middleeast/raqqa-kurdish-female-fighters/index. html>. Acesso em: 9 fev 2018. .

BEAUVOIR, S. Le Deuxième Sexe. Paris: Gallimard, 1949.

BENSON-SOKMEN, S. The Limits of 'Western” Feminist Engagement with Kurdish Female Militancy. Muftah, 20 mar. 2017.

ÇAHA, O. The Kurdish Women's Movement: A Third-Wave Feminism Within the Turkish Context. Turkish Studies, v. 12, n. 3, p. 435-449, set. 2011.

ÇANDAR, C. Erdogan to Continue PKK Talks Despite Paris Murders. Al-monitor, 13 jan. 2013. Disponível em: < https://www.al-monitor.com/ pulse/originals/2013/01/murders-paris-kurds-pkk.html >. Acesso em: 19 fev. 2018.

COUNCIL ON FOREIGN RELATIONS. Interactive: The Time of the Kurds. Council on Foreign Relations, 4 out. 2017. Disponível em: $<$ https:// www.cfr.org/interactives/time-kurds\#!/?cid=soc-at-the_time_of_the_ kurds-infoguide >. Acesso em: 15 fev. 2018. 
CRENSHAW, K. Demarginalizing the Intersection of Race and Sex: A Black Feminist Critique of Antidiscrimination Doctrine, Feminist Theory and Antiracist Politics. University of Chicago Legal Forum, Chicago, v. 1989, n. 1, 1989.

CUNHA, D. O.; KARADA, B. Confederalismo Democrático: Nota Introdutória. Cadernos CERU, São Paulo v. 6, n. 2, p. 114-116, dez. 2015.

DIRIK, D. Feminist pacifism or passive-ism? Open Democracy, 7 mar. 2017. Disponível em: < https://www.opendemocracy.net/5050/dilar-dirik/ feminist-pacifism-or-passive-ism>. Acesso em: 11 fev. 2018.

DIRIK, D. Western fascination with 'badass' Kurdish women. Al Jazeera, 29 out. 2014. Disponível em: < http://www.aljazeera.com/indepth/ opinion/2014/10/western-fascination-with-badas-2014102112410527736. html >. Acesso em: 14jan. 2018.

DIYAR, Z. The Whole World is Talking about Us, Kurdish Women. In: DER MAUR, R.; STAAL, J.; DIRIK, D. (Org.). New World Academy Reader \#5: Stateless Democracy.

DÜZGÜN, M. Jineology: The Kurdish Women's Movement. Journal of Middle East Women's Studies, Bloomington, v. 12. n. 2, p. 284-286, jul. 2016.

ENZINNA, W. A Dream of Secular Utopia in ISIS' Backyard. The New York Times, 24 nov. 2015. Disponível em: < https://nyti.ms/1NpF6WD>. Acesso em: 13 nov. 2018.

FRASER, N. Mapeando a imaginação feminista: da redistribuição ao reconhecimento e à representação. Estudos Feministas. Florianópolis, v. 15, n. 2, p. 291-307, maio/ago. 2007.

FRIEDAN, B. The Feminine Mystique. Nova York: W. W. Norton, 1963.

GHAZZAWI, R. Decolonising Syria's so-called 'queer liberation'. Al Jazeera, 5 ago. 2017. Disponível em <http://www.aljazeera. com/indepth/opinion/2017/08/decolonising-syria-called-queerliberation-170803110403979.html>. Acesso em: 14 jan. 2018.

GONZÁLEZ, L. Racismo e Sexismo na Cultura Brasileira. Revista Ciências Sociais Hoje. São Paulo: Cortez 1984, p. 223-244. 
GRAEBER, D. No. This is a Genuine Revolution. In: DER MAUR, R.; STAAL, J.; DIRIK, D. (Org.). New World Academy Reader \#5: Stateless Democracy. Utrecht: BAK, 2015, p. 194-209. Disponível em:< http:// newworldsummit.org/wp-content/uploads/2015/06/NWA5-StatelessDemocracy.pdf $>$. Acesso em: 14jan. 2018.

GRIFFIN, E. These Remarkable Women Are Fighting ISIS: It's Time You Know Who They Are. Marie Claire, 30 set. 2014. Disponível em: < http:/www.marieclaire.com/culture/news/a6643/these-are-the-womenbattling-isis/>. Acesso em: 9 fev. 2018.

GROJEAN, O. The Production of the New Man Within the PKK. European Journal of Turkish Studies, Paris, 9 jul. 2014. Disponível em $\leq$ http://journals.openedition.org/ejts/4925>. Acesso em: 9 fev. 2018. GUILLAUMIN, C. Prática de poder e ideia de natureza. In: FALQUET, Jules et.al. O patriarcado desvendado: teoria de três feministas materialistas. Recife: SOS Corpo, 2014.

GÜNEŞER, H. Feminicide. In: DER MAUR, R.; STAAL, J.; DIRIK, D. (Org.). New World Academy Reader \#5: Stateless Democracy. Utrecht: BAK, 2015, p. 58-69. Disponível em: < http://newworldsummit.org/wpcontent/uploads/2015/06/NWA5-Stateless-Democracy.pdf >. Acesso em: 14 jan. 2018.

HOOKS, b. Ain't I a woman: Black women and feminism. Nova York e Londres: Routledge, 2015.

JACKSON, R. War on terrorism. In: Encyclopcedia Britannica, 2018. Disponível em: <https://www.britannica.com/topic/war-on-terrorism>. Acesso em: 11 fev. 2018.

JOHNSON, G. Meet the Kurdish Female Freedom Fighters of Syria. Vice, 29 out .2013. Disponível em: < https://www.vice.com/en_us/ article/4w7yk3/meet-the-kurdish-female-freedom-fighters-of-syria>. Acesso em: 9 fev. 2018.

KAYA, G. Why Jineology? Re-Constructing the Sciences Towards a Communal and Free Life. In: DER MAUR, R.; STAAL, J.; DIRIK, D. (Org.). New World Academy Reader \#5: Stateless Democracy. Utrecht: BAK, 2015, p. 84-95. Disponível em: <http://newworldsummit.org/wp-content/ uploads/2015/06/NWA5-Stateless-Democracy.pdf >. Acesso em: 14 jan. 2018. 
KESLASSY, E. Rising Stars Topline French Debut Feature About Female Kurdish Warriors (EXCLUSIVE). Variety, 11 jan. 2018. Disponível em $<$ http://variety.com/2018/film/news/caroline-fourest-french-debutfeature-female-yazidi-warriors-red-snake-1202659570/>. Acesso em: 9 fev 2018.

KNAPP, M.; FLACH, A.; AYBOGA, E. Revolution in Rojava: Democratic Autonomy and Women's Liberation in Syrian Kurdistan. Londres: Pluto Press, 2016.

LES HEROS kurdes de Kobané reçus par François Hollande. France 24, 10 fev. 2015. Disponível em: <http://www.france24.com/fr/20150210-francekurdes-syrie-francois-hollande-paris-etat-islamique-pyd-ypg-pkkturquie-terroriste>. Acesso em: 11 fev. 2018.

MAHMOOD, S. Feminist Theory, Embodiment, and the Docile Agent: Some Reflections on the Egyptian Islamic Revival. Cultural Anthropology, New York, v. 16, n. 2, p. 202-235, 2001.

MEAD, M. Sex and Temperament in Three Primitive Societies. New York: W. Morrow \& Company, 1935.

MOGELSON, L. Dark Victory in Raqqa. The New Yorker, Letter from Syria, 6 nov. 2017. Disponível em: <https://www.newyorker.com/ magazine/2017/11/o6/dark-victory-in-raqqa?mbid=social_facebook $>$. Acesso em: 11 fev. 2018.

ÖCALAN, A. Confederalismo Democrático. Cadernos CERU, São Paulo, v. 6, n. 2, p. 117-132, dez. 2015 .

ÖCALAN, A. Liberating Life: Woman's Revolution. Londres e Colônia: Transmedia Publishing, 2014, International Initiative Edition. Disponível em: <http://www.freeocalan.org/wp-content/ uploads/2014/06/liberating-Lifefinal.pdf >. Acesso em: 19 fev. 2018

SGRENA, G. Commander Nesrin Abdullah: The Other Half of Rojava. The Bullet, International Relations 7 jul. 2015. Disponível em <https:// socialistproject.ca/2015/07/b1137/>. Acesso em: 10 fev. 2018.

SZANTO, E. Depicting Victims, Heroines, and Pawns in the Syrian Uprising. Journal of Middle East Women's Studies, Bloomington, v. 12, n. 3, p. 306-322, nov. 2016. 
TAX, M. A Road Unforseen: Women fight the Islamic State. Nova York: Bellevue Literary Press, 2016a.

TAX, M. When Women Fight ISIS. The New York Times, New York, 18 ago. 2016b. Opinion. Disponível em: < https://www.nytimes.com/2016/08/18/ opinion/when-women-fight-isis.html>. Acesso em: 9 fev. 2018.

VICE. A revolução mais feminista que o mundo já testemunhou. Tradução Marina Schnoor. Vice. 27 jul. 2017. Disponível em: < https:// www.vice.com/pt_br/article/9kwpzv/revolucao-mais-feminista?utm source=vicefbbr $>$. Acesso em: 10 fev. 2018.

WHO are the Kurds? BBC News, Londres, 31 out. 2017. Disponível em: $<$ http://www.bbc.com/news/world-middle-east-29702440>. Acesso em: 11 fev. 2018. 
12

\section{MARIELLE, PRESENTE!}

Um luto político e

uma reconfiguração

da política nacional -

a necessária articulação

de um pensamento liberal

brasileiro que incorpore

demandas sociais e de

inclusão

Heloisa Pait

Renata Nagamine 


\section{Um evento simbólico}

Neste artigo analisamos o significado nacional dos protestos em repúdio ao assassinato de Marielle Franco, vereadora em primeiro mandato pela cidade do Rio de Janeiro, ocorrido em 2018 quando ela saía de um encontro com ativistas negras, parte das atividades de seu mandato. Refletimos sobre o luto por sua morte, os protestos a favor das investigações e as manifestações nas redes sociais em apoio ou contrárias a estes protestos. Para isso, usamos a ideia de Clifford Geertz (1973) sobre fenômenos culturais, sinteticamente a de que eles dizem algo sobre a sociedade para ela mesma, ou seja, são locais simbólicos de reflexão social os quais cabe ao analista interpretar. Também usamos as ideias de Elihu Katz (DAYAN; KATZ, 1994) sobre eventos mediáticos com forte caráter ritualístico, ainda que no caso analisado não tenha havido uma solenidade televisionada, mas protestos organizados de modo independente, coincidindo com datas de luto.

O assassinato foi extensamente coberto pela imprensa, em suas várias dimensões, incluindo os protestos de rua e as demandas pelo esclarecimento do crime: Marielle era uma figura local da política carioca, mas encaminhava-se para se tornar uma figura nacional por seu carisma e capacidade de articulação. Houve grande repercussão internacional, ainda que esta não tenha, de modo geral, muita ressonância no debate nacional. Várias cidades tiveram protestos, concentrados na cidade da vereadora, o Rio de Janeiro, onde ela morava, havia estudado e feito pós-graduação, e onde havia começado seu ativismo e trabalho na câmara dos vereadores como assessora parlamentar. Uma das autoras deste artigo participou de um protesto em São Paulo que marcou os sete dias de sua morte e a outra acompanhou os acontecimento a partir de uma cosmopolita cidade australiana. O significado destes protestos não é unívoco, dado o tamanho e a pluralidade da sociedade brasileira e particularmente a polarização política que tomou conta do país desde, no mínimo, as eleições de 2014. Neste artigo, exploramos algumas possíveis interpretações dos protestos e oferecemos a nossa própria, que leva em conta a estrutura política nacional mais perene. De modo muito sintético, sustentamos que a morte 
de Marielle Franco desencadeou uma guinada no conturbado debate político brasileiro dos últimos anos. Reconhecemos a importância de sua atividade pela luta de minorias e o caráter identitário das manifestações em repúdio ao seu assassinato, mas nossa interpretação vê esta luta identitária como nó político em que se entrelaçam questões mais amplas, ligadas ao próprio consenso democrático nacional.

O artigo aborda esse marcante fato político a partir de várias perspectivas. Trazemos inicialmente uma narrativa do assassinato de Marielle, dos protestos que se seguiram e das reações aos protestos, mostrando sua relevância para o quadro político mais geral nacional. Recuperamos a seguir um momento histórico relevante para compreender o papel do liberalismo no Brasil e suas dificuldades para se consolidar como uma voz possante na cacofonia da política nacional. Entretanto, o assassinato de Marielle também tem dimensões que vão além da política brasileira. Para trazer este importante contexto, resgatamos o estado atual do pensamento liberal e os desafios que encontra no plano das ideias e da prática, particularmente relevantes hoje quando parece imprensado entre correntes a ele hostis. Tal reflexão será relevante pois as interpretações da morte de Marielle vão expressar distintas visões do papel do indivíduo na sociedade e da convivência entre semelhantes, ou seja, as manifesta ções serão um local de contestação em torno de valores liberais e também democráticos. Complementamos essa dimensão internacional inserindo os protestos de repúdio à morte de Marielle Franco dentro do debate internacional e da luta pelos direitos humanos.

Buscamos assim refletir, a partir deste evento traumático da vida política brasileira, sobre o lugar do indivíduo e o futuro do pensamento liberal nesse momento de encruzilhada no Brasil e no mundo. A surpreendente conclusão a que chegamos, ao final, é que Marielle é reduzida a uma vítima a mais pelos extremos do espectro político nacional, tanto à direita como à esquerda, enquanto aqueles mais próximos do pensamento liberal conseguem enxergar na vereadora um sujeito autônomo que é parte atuante de um sistema político representativo. Resgatar sua vida enquanto sujeito autônomo passa a ser um dever acadêmico mas também ético e político. 


\section{O fim de uma aliança}

Fomos descobrindo aos poucos a vida de Marielle Franco, a vereadora de sorriso iluminado pela cidade do Rio de Janeiro. Uma amiga nos disse que seus colegas da Universidade Federal Fluminense (UFF), onde a vereadora fez mestrado, a conheceram pessoalmente. Um site judaico progressista contou que ela compartilhava da preocupação de seu companheiro de partido, Jean Wyllys, do Partido Socialismo e Liberdade (PSOL), com o antissemitismo da esquerda. Vimos sua família e ouvimos sua filha falar na TV, ainda chocada mas confiante que o crime seria solucionado, e uma identificação mais humana foi se estabelecendo entre nós e esta mulher que lamentamos não ter conhecido. Quando a mãe de uma de nós faleceu, o rabino disse: "Pense como ela viveu, e não como morreu." Ele repetia a frase de tanto em tanto para uma família atordoada, como esteve a família da Marielle, que tem inscrito sua vida na história política de nosso país com homenagens, depoimentos e atividades que honram seus valores e ações. Mas foi através do assassinato que a maior parte de nós conheceu Marielle, então é inescapável falar do que ele significou para todos nós, naquele momento político nacional.

Desde a eleição de 2014, com a tomada de consciência de que o país rumava para uma situação econômica insustentável, tivemos uma desconfortável aliança entre social-democratas e conservadores, herdeiros políticos dos antigos Partido Social Democrático (PSD) e União Democrática Nacional (UDN), contra o estatismo então no poder. Expliquemos. O PSD era o partido do mineiro Juscelino Kubitschek de Oliveira, comprometido com a democracia e com o desenvolvimento. Teve seu mandato presidencial ameaçado por golpes militares e era o candidato às eleições de 1965, que nunca aconteceram. A UDN, de Lacerda Franco e Jânio Quadros, era o partido conservador nos costumes, mas liberal na economia. Já o Partido Trabalhista Brasileiro (PTB), de Leonel Brizola e João Goulart, idealizado por Getúlio Vargas, representava o estatismo, um pouco mais ou um pouco menos autoritário, mas centralista certamente. Quando olhamos o quadro político atual, multipartidário, fica difícil ver alguma coerência 
nas alianças e nas visões de mundo de cada agremiação; entretanto, ele se aclara quando o olhamos através destas siglas, PSD, UDN e PTB.

Essa digressão é necessária porque nossa tese é que a morte de Marielle desencadeou um rearranjo nacional expressivo e ainda não resolvido nesse quebra-cabeças, que é partidário, mas também de valores e visões de mundo e de país. O PSD, com sua ênfase democrática, desenvolvimentista e progressista, seria um precursor do Partido da Social Democracia Brasileira (PSDB) de Fernando Henrique Cardoso, com sua aposta internacional, que não se descuida, porém, do desenvolvimento nacional. É o partido que mais se assemelha ao Partido Democrata americano ou aos partidos social-democratas europeus do passado recente. O Partido dos Trabalhadores (PT), com sua base sólida dentro do próprio Estado, ainda que hoje esgarçada, e sua relação ambígua com relação aos valores liberais e democráticos, como a liberdade de expressão, pode ser considerado um herdeiro do PTB, apesar de seu rechaço explícito a essa agremiação. As políticas públicas patrimonialistas que implementou no governo reforçam esse elo. A direita nacional ficou órfã de representação partidária com a derrocada da ditadura e a conversão dos partidos de sua base, o Partido Democrático Social (PDS) e o Partido da Frente Liberal (PFL), em siglas indistinguíveis de uma massa de partidos irrelevantes isoladamente, tanto numérica quanto simbolicamente. Os atuais Partido Progressista Nacional (PP) e Democratas (DEM) não representam o pensamento conservador nacional, tendo o primeiro se aliado a governos de esquerda e o segundo nunca conseguido se firmar como partido independente. A UDN, uma força política de peso que foi parar na Aliança Renovadora Nacional (Arena) durante o regime militar, sumiu como força simbólica relevante depois da redemocratização.

Voltando ao presente, podemos dizer que tivemos, entre a eleição de 2014 e a votação do impeachment de Dilma Rousseff, uma aliança incômoda do campo democrático e progressista, tributário do PSD, com o difuso campo liberal tradicional, tributário da UDN, que abarcava desde Ronaldo Caiado a Aloysio Nunes Ferreira. Quem participou das manifestações antigovernamentais de 2015 e 2016 sabe que era muitas vezes difícil estar ao lado dos monarquistas, da TFP (Tradição, Família e Propriedade), uma 
antiga organização de ultra-direita, e de novos grupos de direita, como o Revoltados Online. Alguns antigovernistas expressavam seu desacordo ao passar por eles, com vaias e palavras pouco amistosas. Tinha-se vontade de voltar no tempo, para os comícios onde cantavam Chico Buarque e Fafá de Belém e subiam no palanque Covas e Lula, Montoro e Fernando Henrique. Estávamos, nós que acreditamos no valor da vida humana e defendemos o direito reprodutivo, que vimos nossas mães quebrando barreiras no trabalho e ousando na vida privada, que testemunhamos nossos amigos afirmando, com dificuldade mas alegria, suas orientações sexuais, estávamos marchando ao lado dos ultraconservadores e da direita. Essa jornada comum pelo impeachment parecia necessária a uns e outros, mas não era confortável. Era uma aliança que se mantinha em torno de bandeiras comuns anti-corrupção, anti-estatistas e, agora fica mais claro, anti-PT.

Essa aliança provisória teve um fim abrupto com a morte de Marielle Franco. Ficou claro para seus membros que eles compartilhavam alguns objetivos, mas tinham visões de mundo díspares. Isso não foi de modo algum responsabilidade de Marielle, uma pessoa, pelo quelemos naimprensa, que buscava agregar pessoas e por isso era bem quista por familiares de policiais abatidos por essa violência terrível da nossa cidade maravilhosa. Como esse divórcio ocorreu? As manifestações a favor de investigações e em homenagem a Marielle foram, sim, políticas, duras e recriminatórias. Diziam: “Olhem, vocês do golpe de 2016, olhem isso onde deu!” Mas também foram sentidas, humanas, dignas e pacíficas. Paradoxalmente, não foi a dureza e a politização que incomodaram tanto os assim chamados "coxinhas", produto da referida aliança: foi o fato de que o protesto era absolutamente necessário, legítimo, correto, irrepreensível. Afinal, o que é mais valioso que a vida humana? Como condenar a indignação de mulheres, negros, ativistas de esquerda e jovens vendo um dos seus ser abatido sem mais nem porquê? Parte da reação aos protestos foi virulenta, levantando toda sorte de calúnias sobre a vereadora, que depois se descobriu foram reproduzidas de modo concertado por uma das organizações políticas que emergiu nos movimentos a favor do impeachment de Dilma Rousseff. Mas parte desta reação, mesmo sem o ódio, apenas com 
um fel ressentido de quem perde o protagonismo, buscava deslegitimar o caráter político da execução, colocando-a na vala dos 60 mil assassinatos anuais no país, pedindo uma tolerância para um crime que não pode ser tolerado, pois ameaça a democracia.

Os atos em memória de Marielle Franco foram os primeiros protestos de rua chamados pela esquerda em muito tempo que se legitimavam a partir de valores comuns a todos nós: a defesa da vida, da liberdade de expressão e da democracia institucional. Foi essa legitimidade que questionou a aliança que, até aquele momento, se via como detentora monopolista da justiça. Não se tratava mais da defesa de um condenado e de trapaças; de políticas desastrosas e desvios de verba: era um protesto legítimo e ao mesmo tempo desprezado por parte da aliança pelo impeachment. Devese notar, entretanto, que os protestos foram apresentados pelos manifestantes como parte de uma luta identitária ideológica que rechaçava novas alianças, o que pode ser atribuído à polarização política atual ou à própria natureza destes movimentos identitários.

Na crítica aos protestos, houve preconceito explícito com a origem social da vereadora, como o de uma desembargadora e de um infeliz deputado. Por exemplo, insinuou-se que Marielle tinha sido assassinada por relações com o Comando Vermelho, e pelas mídias sociais circularam fotos em que uma mulher que seria ela aparecia ao lado de um chefe da organização. Mais importante que isso, para nosso argumento, foi o fel dos que entenderam a gravidade do atentado e se ressentiram de um luto e uma luta que não era mais deles. Aí fizeram acrobacias mentais admiráveis para diminuir a importância de um evento de tamanho impacto nacional e internacional. Contestaram que Marielle fosse, de fato, cria da comunidade, já que ela morava na Tijuca e seus votos vinham do Leblon, e argumentavam que não se tratava de crime político. Depois dos sommeliers de tragédia e de protesto, vieram os de funeral, dizendo quais mortes se pode chorar e como é apropriado fazê-lo. Seus questionamentos eram tanto mais absurdos quanto mais se sabia: Marielle estava, no momento da execução, saindo de um compromisso da vereança, ao final de um dia de agenda intensa, fazendo o trabalho para o qual tinha sido eleita. 
(MESQUITA, 2018) Ela tinha sido morta, portanto, como vereadora, e não no espaço doméstico, ou devido à sua condição social.

Nesse momento rompeu-se a aliança UDN e PSD, o que se expressou no quadro eleitoral de 2018, com a UDN se concentrando em torno de um novo Jânio Quadros, impoluto e carismático, e o PSD demorando a encontrar seu candidato. Mesmo com o desgaste do passado, com a cumplicidade dos partidos progressistas devido ao escândalo do Petrolão, não era mais possível estar ao lado dos que afrontam os direitos básicos que associamos à cidadania. O julgamento a respeito do funeral ajudou a romper com a aliança entre, ainda usando as siglas antigas que enquadram melhor a política brasileira do que os partidos atuais, a UDN e o PSD, sendo que esse último ficou solto, em busca de um candidato, de um líder, de um partido, de uma identidade resgatada.

Somos, e aqui obviamente nos colocamos nesse campo, a favor da liberdade e do desenvolvimento humano, temos ojeriza ao autoritarismo varguista, mas também medo do machismo e da intolerância em suas várias formas. Somos naturalmente de centro, tanto ideologicamente como na busca de uma sociedade em que caiba uma variedade de posições. É verdade que essa visão progressista desgastou-se no passado recente com o desenvolvimentismo retrógrado de alguns líderes e o Estado do Bem-Estar patriarcal de outros. O termo derrogatório “isentão”, na moda nos anos do impeachment de Dilma Rousseff, refletiu bem o cansaço com esse progressivismo hesitante, que faz privatização com dinheiro de banco público e participa de protesto da sacada de Ipanema. Mas esse desgaste conjuntural não reduz sua importância para a democracia nacional. E, a cada dia, passa a ser mais importante o resgate da social democracia no seu sentido mais profundo, o de força política que aceita de coração a democracia e vê a inclusão social como parte do mesmo projeto, e não como forma de dominação da sociedade pelo Estado.

\section{Liberalismo interrompido}

Esta não é a primeira vez na história que liberais rechaçam valores do centro moderado. Antônio Paim (1998) estudioso da história do liberalismo 
brasileiro, já havia apontado o erro dos liberais em, depois do fim da ditadura Vargas, voltar à cena política sem ideias renovadas, sem a preocupação social que liberais no mundo todo haviam incorporado após a dramática crise de 1929 e a tragédia da Segunda Guerra Mundial. Os UDNistas, entre os quais o mais conhecido é o cultíssimo Carlos Lacerda, evitavam com isso dar o braço a torcer ao abominado populismo de Vargas, mas tal recusa a incorporar a questão social, para Paim, radicaliza a UDN num anti-varguismo que desemboca no golpe de 1964. Acontece algo semelhante agora: depois de um longo período de hegemonia política desse grupo estatista, ainda que não de domínio autoritário como houve durante o Estado Novo, parece que, como no pós-guerra, quer-se voltar ao tempo e rechaçar as transformações sociais ocorridas no mundo e no Brasil. Desta vez, os UDNistas optam por deslegitimar a presença das mulheres na vida pública, que é um fato, com receio de desembocar na agenda identitária construída nas últimas décadas. Busca-se ignorar a inclusão social, que é parte da vida social liberal e democrática no mundo todo. Dito de outro modo, quis-se apagar o fato óbvio de que Marielle Franco era negra, oriunda da favela, e era também vereadora.

Houve, como dissemos, os que criticaram a pessoa de Marielle Franco, insinuando as coisas mais estapafúrdias possíveis. Esses mostraram preconceito e desumanidade. Mas houve os que quiseram que a morte dela fosse tratada como uma entre as milhares que acontecem todos os anos, sem o que chamaram "politização": apenas uma vida perdida para a violência urbana. Era como se quisessem apagar o fato de que uma mulher, negra, homossexual e vinda de uma favela tinha conseguido se tornar uma liderança política expressiva a ponto de levar a uma comoção geral. Nada teria ela a ver com John F. Kennedy ou com Juscelino Kubitschek, com Martin Luther King ou Harvey Milk, políticos importantes cujas mortes foram lamentadas, investigadas e continuam sendo rememoradas. Marielle seria apenas uma mulher qualquer, sem cor política, sem voz própria, sem seguidores, dessas tantas que morrem atropeladas, ou espancadas, ou assaltadas, ou apenas pelo azar de estarem na linha de uma bala perdida, sozinhas ou com seus bebês na barriga. Vítimas anônimas. 
Os Lacerdas de hoje pedem à nação que esqueçam as décadas de inclusão, devida, em parte, a políticas específicas, em parte a esforços individuais, e também à própria dinâmica das sociedades onde há liberdade de escolhas, inclusive de empreender, e justiça. Lembremos que a inclusão de minorias, como política pública, entra em cena nos anos 1960, como resposta das universidades americanas para os conflitos raciais que pareciam exigir mais do que apenas direitos iguais. (STULBERG; CHEN, 2008) Concordando ou não com tais políticas, é fato que elas chegam ao Brasil, com atraso, e seria legítimo questionar se foram aqui aplicadas de modo produtivo ou se foram utilizadas como instrumento de cooptação para um projeto político que nada tinha de igualitário. O que não se pode negar é que a sociedade brasileira é hoje mais inclusiva que ontem, com negros e mulheres ocupando posições de destaque nos negócios, na ciência e nos meios de comunicação. O maior significado da crítica aos protestos contra o assassinato de Marielle é, portanto, a negação de todo o processo de inclusão na sociedade brasileira.

Não se trata de uma volta conservadora ao tempo em que estruturas hierárquicas de classe, gênero, raça e orientação sexual permaneciam incontestadas, mas sim de uma relativização dos valores liberais, que teve repercussões políticas importantes. O retorno a valores tradicionais exigiria o discurso de proteção a Marielle e outras mulheres que andam nas ruas das grandes cidades brasileiras, o que não seria de todo indesejada. Não se tratava tampouco de uma asserção de valores liberais clássicos, o que exigiria juntar-se aos que pedem investigações céleres e proteção efetiva aos representantes legislativos, da qual depende a democracia nacional. Talvez o resultado tenha sido o reforço do discurso reacionário sobre gênero; mas pode ter tido mais chance o reforço de nosso arraigado preconceito de classe. O principal efeito dos esforços de deslegitimação de Marielle como atriz política e, por tabela, de toda a história de inclusão das últimas décadas não é direto: é um indesejável cisma entre liberais e progressistas, com os UDNistas ressurgindo no espectro político não só de forma autônoma, o que não seria mal de todo, mas se inclinando decididamente à direita. Ou seja, podia-se ter a ilusão de que essa UDN permanecia como um apêndice do PSD durante os anos FHC e os anos de 
liderança tucana na oposição. Agora fica claro que esse pensamento político apenas não tinha a representação devida que agora busca. Nunca é demais lembrar que no passado esse divórcio deu no golpe de 1964.

A UDN que no passado aninhou-se na polarização da Guerra Fria hoje busca valores de uma direita radical que se articula globalmente e traz uma ameaça real para a democracia e desconhecida das atuais gerações. Conclamamos portanto à busca da conciliação e alargamento de alianças, com reconhecimento da inclusão social e respeito à esfera privada, também em suas expressões conservadoras. Essa proposição se justifica porque é preciso ter em mente que a nova direita não é conservadora: ela é revolucionária e propõe a transformação militante de valores na esfera pública, o que é perigoso para a liberdade individual. Os progressistas, agora, devem voltar a buscar o meio-termo, as posições conciliatórias, a moderação e o alargamento das alianças. Não é possível lutar ombro a ombro com quem acredita que a vida de um ser humano vale pouco, e fica difícil fazê-lo com quem está disposto a desvalorizá-la por conveniências políticas. Se é verdade que reduzir a morte de Marielle a uma questão de gênero ou raça é inadequado, negar que foi uma mulher que morreu enquanto fazia sua voz se ouvir - como fizeram tantas de nós nessas últimas décadas - é um completo absurdo. Liberais de fato reconhecem a estupenda história global de inclusão das últimas décadas, ao invés de, como no pós-guerra, voltarem seus relógios para trás em busca da restauração de ordens desafiadas e ao lado de utopias regressivas. Homens de verdade estão se perguntando: que cidades são essas que construímos que não oferecem proteção mínima, nem mesmo às mulheres? Homens e mulheres de verdade olham os fatos e buscam compreender qual seu papel diante deles. A morte de Marielle, ainda não elucidada, recoloca-nos, a todos nós, essa pergunta: qual nosso papel diante do Brasil de hoje? É nesse sentido que dizemos, Marielle, presente!

Essa nossa militância, entretanto, não implica ignorar os tremendos obstáculos à construção de um novo liberalismo brasileiro que vêm tanto da direita quanto da esquerda. Como dissemos, as reações aos protestos pela morte de Marielle foram amplificados, no diálogo digital, por ativistas pagos e de modo concertado. (CARIELLO; GRILLO, 2018) No Brasil 
e no mundo, é impossível ignorar os desafios ao diálogo democrático colocados por meios de comunicação que, duas décadas atrás, víamos como a cristalização do ideal iluminista do conhecimento livre e de um humanismo sem fronteiras. No caso de Marielle, as reações a seu assassinato evidenciaram o potencial desses meios de criar ficções que pareciam ganhar densidade à medida que eram compartilhadas por mídias sociais, passando a concorrer com os fatos, os fatos reais, conforme circulavam. Em lugar de aumentar a simetria na esfera pública, o uso desses meios de certo modo a deformava; em lugar de constituir o humano em interações subjetivas, como postulou Hannah Arendt (2004), essas interações se constituíam em esforços desumanizadores. Reconheçamos, também, que os desafios a alianças políticas mais profícuas não vem apenas daquela recusa UDNista em olhar para novos fenômenos políticos. É também verdade que a trajetória de Marielle foi vista, em particular pela esquerda universitária, como produto e símbolo das políticas de inclusão dos últimos governos, ou seja, como triunfo de uma certa visão de mundo. Se esse ambiente universitário foi onde ela se formou e progrediu, isso por si só não responde, entretanto, por sua constituição como pessoa e líder. Nesse ponto, a teoria política pode nos ajudar a pensar a relação entre identidades e individualidade.

A relação entre as identidades e o campo político tem sido um objeto preferencial do debate feminista desde finais dos anos 1980 e 90, quando se colocou nesses termos na academia norte-americana. Nesse debate, Fraser representa um esforço de síntese (CYFER, 2009) entre posições modernas, que negligenciariam a formação da subjetividade, e pós-modernas, que as enfocariam, mas, paradoxalmente, negligenciariam a dimensão intersubjetiva desse processo. Engajada nessa troca de ideias ao longo dos anos 1990, Fraser (1996) aborda as chamadas questões identitárias e as materiais, ou distributivas, como problemas de justiça que poderiam ser remediados pelo reconhecimento ou pela redistribuição, mas que eram primordialmente relacionados com a paridade. Elas eram, em síntese, uma questão de igual status nas interações sociais. Não remetiam a demandas pela valorização da diferença, nem aventavam qualquer tipo de reformismo social ou das mentalidades, e isso não porque a dimensão 
psíquica, da autoestima, não tivesse importância, mas porque ela não podia ser observada na análise social e daria abertura a projetos autoritários. Comprimida entre as visões mais ideológicas que se apropriam da figura de Marielle, fica, então, essa que propomos aqui, de um indivíduo autônomo e uma representante eleita por um eleitorado construído politicamente. Se essa multiplicidade de percepções sobre sua jornada fez de seu assassinato um marco político, também é verdade que estas percepções ainda se chocam em outras oportunidades, sem que saibamos como avançar a que mais oferece possibilidades para um diálogo de ampla envergadura.

Em outras palavras, os desafios para a construção de um discurso liberal, democrático e progressista, no Brasil, não são poucos. Marielle sem dúvida não pode ser esquecida, mesmo diante de tantos dramas nacionais que se sucedem a cada dia. Mas qual Marielle? Aquela que apenas reflete uma visão de mundo identitária, gestada na universidade? A mulher que se meteu onde não devia? Ou a representante eleita, democraticamente, morta no exercício de suas funções parlamentares, que são a de ouvir a população e buscar soluções para seus problemas?

\section{Facetas do liberalismo}

Olhemos agora esse evento trágico numa perspectiva mais ampla, considerando desafios locais e globais com os quais liberais de todo o mundo têm se deparado. O assassinato da vereadora Marielle Franco, em 14 de março de 2018, nos convoca a pensar os limites, as possibilidades e a importância do liberalismo em uma sociedade com uma história de períodos autoritários intermitentes e com demandas sociais e de inclusão prementes, como é o caso da sociedade brasileira.

Não somos as únicas no campo liberal a atender a esse chamado da consciência. Há uma profícua e recente literatura sobre o tema, que compreende desde The Once and Future Liberal, de Mark Lilla, (2017) a Como as democracias morrem, de Steven Levitsky e Daniel Ziblatt (LEVITSKY; ZIBLATT, 2018) Evocamos também o recente ensaio de Andrea Faggion 
(2018) publicado em meio às disputadas e potencialmente mais importantes eleições brasileiras desde a redemocratização.

Nele, Faggion parte da postulada neutralidade diante das escolhas individuais, que o pensamento liberal justifica como sendo uma posição natural ou necessária a assegurar a pluralidade de ideias, opiniões e ideais de boa vida, para defender que o pensamento liberal assuma uma concepção de bem. É realmente comum se argumentar que o liberalismo não encerra uma ideia de bem, mas se propõe a articular e sustentar uma configuração política que contemple múltiplos compromissos com o bom, o qual é por definição relativo: o bom é sempre bom para. (ARENDT, 1990) Esta é uma imagem que o liberalismo cultiva de si mesmo e uma postura, como dissemos, diante da pluralidade de opiniões, valores e escolhas, tomada como um dado de realidade, um fato da vida. Essa postura não implica, contudo, relativismo moral (GEERTZ, 2001), ou seja, abrir mão de distinguir o certo do errado desde uma perspectiva moral, e sim buscar compreender sem ser compreensivo, como disse Geertz. Desde a perspectiva liberal a qual nos filiamos, este esforço se justifica em função do compromisso fundamental do liberalismo com a liberdade, que, em termos políticos, encerra a forma democrática. Para liberais no sentido em que reivindicamos o termo, a ordem é um produto da liberdade regulada, isto é, de uma liberdade constituída pelo direito (KANT, 2003), que substitui a guerra de todos contra todos, entendida como qualquer situação em que a lei do mais forte se impõe como a lei da terra.

Mas, se é assim, o liberalismo não é propriamente neutro em relaçãoàs concepções de boa vida. Ele tem um compromisso com a autonomia, com a ideia de que a relação de todos com o Estado e de uns com os outros depende do compromisso com a coabitação e o consentimento individual, que se entende ser tácito para conciliá-lo com a necessidade de manter a estrutura básica em que a ação política tem lugar. Se discordamos das leis pelas quais nos obrigamos, podemos agir para alterá-las, ou seja, podemos agir politicamente, pois a liberdade de discordar, expressar dissenso e buscar apoio para as alterações propostas é assegurada. Nessa linha de argumentação, o liberalismo também estaria comprometido com a mudança social pacífica, para a qual os direitos humanos são instrumentais, 
por possibilitarem aos indivíduos desafiar leis formais, bem como costumes, tradições, crenças e práticas. No Brasil, eles foram usados, por exemplo, tanto em ações coletivas, para formular demandas por direitos civis e sociais, quanto para fundamentar decisões judiciais sobre cotas raciais, o aborto de feto anencéfalo e o reconhecimento das uniões estáveis entre pessoas do mesmo sexo como entidade familiar. Ressaltar a importância dos direitos humanos para a democracia não implica, é claro, ter uma relação acrítica com eles ou endossar usos meramente instrumentais deles, que contribuam mais para a manutenção de certa ordem das coisas do que para a transformação social. Mas o assassinato de Marielle, uma defensora intransigente dos direitos humanos, mostra seu potencial de desafiar hierarquias remanescentes, como a de gênero e racial, e propostas autocráticas. Os direitos humanos aparecem, em certas quadras políticas, como um elemento de resistência democrática, o que nos ajuda a entender os ataques que sofrem no Brasil e as disputas travadas em torno deles.

Disso temos que o papel do liberalismo em questões de justiça social não pode ser ignorado. $\mathrm{O}$ assassinato de Marielle e sua repercussão, que o constituiu em arena simbólica de conflitos, serviram como campo de batalha entre concepções distintas de direitos e exigem, assim, que repensemos o liberalismo contemporâneo, seus desafios e possibilidades, no plano conceitual e político. Tal arena simbólica estendeu-se além das fronteiras do país, com significados em parte distintos, em parte coincidentes, como trataremos a seguir.

\section{Além das fronteiras}

A morte de Marielle foi destaque fora do país, sendo noticiada por jornais de circulação global, como The Guardian, The New York Times e The Washington Post. Nos dias que antecederam e sucederam o assassinato da vereadora, discutíamos com amigos no Brasil que não sabiam se iam ou não iam aos protestos, temendo que imagens da multidão fossem usadas para fins eleitorais. Ir ou não ir a uma manifestação tinha se tornado um objeto de deliberação no país, uma questão que envolvia pensar, ponderar 
e discernir. Professoras e pesquisadoras australianas e europeias nos procuravam, consternadas, querendo saber mais. Perguntavam se conhecíamos Marielle e qual sua importância e do seu assassinato para a política brasileira. Uma professora eminente comentou com pesar sua morte em um curso sobre direitos humanos; outra tocou no assunto a caminho de uma palestra, com seriedade e inquietação.

A “intervenção militar constitucional” no Rio de Janeiro, então recentemente decretada, aparecia como um aspecto contextual importante. Marielle era uma dura crítica da medida e do que considerava ser a militarização da vida, que para ela recaía especialmente sobre as favelas. Como assessora parlamentar, ela tinha acompanhado de perto o trabalho da CPI das Milícias, no Rio de Janeiro, e como vereadora era membro do Observatório da Intervenção, que fiscalizaria a atuação das forças armadas na cidade. Fora do país, a medida não era apontada como causa do crime, mas era um elemento perturbador por si só, e o assassinato de uma vereadora tão bem votada com uma intervenção na segurança em curso e ocupando o Rio de Janeiro um lugar privilegiado no imaginário dos estrangeiros foi interpretado como um sinal da gravidade da situação política no Brasil.

Um grupo atuante de pesquisadores e professores sul-americanos da Universidade de Melbourne organizou um seminário sobre o significado do assassinato de Marielle e da prisão do presidente Lula para a democracia, ao qual compareceu uma maioria de doutorandos brasileiros e alguns estrangeiros. Sobre Marielle todos concordávamos. Compartilhávamos a percepção de que ela tinha sido morta em função de sua atuação política, de suas falas e práticas denunciando milícias e a violência policial no Rio de Janeiro. Sua morte tinha relação com seus atos e opiniões, ainda que o sentido de sua atuação política também tivesse para ela relação com a cor da sua pele, sua classe social, seu gênero, sua orientação sexual. Marielle identificava-se como mulher, negra, mãe e cria da favela da Maré (HELENA, 2018), e falava, em parte, como representante desses grupos nos espaços institucionais. Um estudioso da atuação de grupos paramilitares no Rio de Janeiro falou sobre o problema e comentou que chegou a conhecê-la. Na troca de impressões e ideias com outros debatedores e a 
audiência, a execução de ativistas de direitos humanos e a violência armada - policial ou paramilitar, ligada ao tráfico ou não - apareceram como uma questão continental, um desafio para as democracias latino-americanas.

O jornal britânico The Guardian recontou a história da vereadora, descrita como uma mulher negra, mãe solteira, moradora da favela, homossexual, inteligente e competente, que entrou para a política ao perder uma amiga morta por uma bala perdida num confronto armado entre a polícia e traficantes na Maré. Marielle, lembrou o jornal, teve contato com a política em uma igreja local, sendo a sua história nesse aspecto semelhante a uma grande parcela da esquerda latino-americana desde os anos 1960, aí incluída a brasileira. No continente de um modo geral, mas especialmente no Brasil, o movimento de direitos humanos foi ganhando forma ao longo dos 1960 e 70 sobretudo nas redes da Igreja Católica (MOYN, 2010), em que se formulou uma corrente de pensamento, a Teologia da Libertação, que enfocava mais as questões de justiça social do que os dogmas e a moralidade cristãos. Segundo o jornal, foi nessa corrente de pensamento, a Teologia da Libertação, que Marielle começou a se constituir como atriz política, e depois foi buscar educação formal, aproveitando as oportunidades que se abriram a ela: o cursinho comunitário pré-vestibular na Maré, onde conheceu Mônica Benício, sua viúva, o ingresso na PUC-Rio, com bolsa da universidade, e o mestrado na UFF.

No luto global, que pudemos acompanhar de várias formas, houve espaço para falas mais identitárias, que colocavam Marielle como uma vítima a mais da violência a que as mulheres estão submetidas, e em particular as negras ou pobres, seja no âmbito familiar ou na vida social. A essas marcas ainda se somava a de cidadã de um país do terceiro mundo, sobre determinando a opressão e o silenciamento de tais vozes. Aos olhos de quem luta pela democracia liberal num país em desenvolvimento, no entanto, tal postura se confunde com a aceitação fatalista de que a violência em certos espaços seja algo perene e que necessariamente atinja os mais desprotegidos. Marielle equipara-se deste modo a Malala Yousafzai, a estudante paquistanesa, ou a adolescente palestina Ahed Tamimi. Malala e Tamimi, porém, são vítimas de um sistema opressor ao qual não 
pertencem, enquanto Marielle pagou um preço por seu próprio sucesso como representante eleita e de futuro promissor no interior de um sistema político. Há, assim, uma perturbadora semelhança entre a visão identitária, nacional e global, e a deslegitimação conservadora que apontamos em seção anterior deste artigo: apesar da diferença em intenções e valores, ambas colocam para trás do palco a líder política de impacto Marielle Franco, reduzindo-a a uma a mais num redemoinho social no qual sua voz não contava.

As duas perspectivas ainda nos fazem perder de vista um aspecto de Marielle que sua morte nos revelou, sua habilidade em tecer alianças, que fica evidente no fato de que ela era uma crítica contundente da violência armada e da atuação da polícia carioca, mas lutava, ao mesmo tempo, pelos interesses das famílias de policiais mortos e dos próprios policiais como servidores públicos. Foram algumas dessas famílias que, quando as notícias falsas em torno de sua morte surgiram, apressaram-se em desmenti-las publicamente, de modo que as práticas de Marielle de que tivemos notícia com seu assassinato evidenciaram sua autonomia e seu olhar singular, que não abria mão nem de julgar os atos, nem de construir alianças que transbordavam as identidades com as quais ela falava de si.

Sua vida também foi contada, para além das narrativas identitárias, do modo como foi vivida entre nós: uma história de superação e de um sucesso improvável, na qual as várias identidades traziam obstáculos que Marielle de fato precisou superar e questões de justiça com as quais se engajou no esforço por tornar viável a própria vida. Listadas em sequência, não eram identidades que falavam por si. Na matéria do The Guardian, vamos nos dando conta de que elas se traduziram em dificuldades muito reais que, como Marielle insistia em mostrar, continuam intervindo no cotidiano das favelas e bairros pobres das nossas cidades. Nessa linha de pensamento, lemos manifestações de pessoas públicas em redes sociais, como a atriz Viola Davis, Hillary Clinton, o casal Obama, e de outros jornais estrangeiros que foram, além disso, inequívocas em afirmar o caráter político do crime, lembrando que Marielle tinha sido morta como uma vereadora do Rio de Janeiro e ativista de direitos humanos, ao sair de um debate com mulheres negras na Lapa. 


\section{Um luto contestado}

No luto pela morte de Marielle Franco, portanto, cruzam-se vários planos que este artigo apenas começa a desenhar. Uma vereança dedicada a buscar uma vida melhor para moradores de favelas cariocas, contra o violento poder local, é promovida por um discurso identitário gestado na cultura americana e apropriado pela academia brasileira. Discursos políticos com firmes raízes nacionais são fortalecidos e também questionados num ambiente comunicativo ainda pouco compreendido. Um liberalismo humanista global, institucional e culturalmente, vê na perda de Marielle motivo de alarme e tenta uma aglutinação que precisa levar em conta significados locais muito particulares.

O evento aqui teve uma relevância política específica, enquanto no exterior ele entrou no quadro mais geral da luta contra a discriminação, um discurso por um lado universalista, que cobra corretamente a apuração de violações aos direitos humanos, mas por outro lado paternalista, como se existisse uma cultura patriarcal e atrasada, irremediavelmente responsável por tais crimes. Tanto no exterior como no Brasil, uma interpretação mais humanista e democrática se desenha, frágil mas persistente, que insiste em ver em Marielle Franco uma mulher de verdade, com sua condição, nos dizeres de Arendt, e sua capacidade de ação. Essa visão precisa se articular de modo politicamente mais efetivo, pois tanto à esquerda quanto à direita houve tentativas de colocar Marielle como uma mera representante de um grupo difuso e subordinado.

Não são de agora, como dissemos, as dificuldades do liberalismo nacional. Sob ataque globalmente, ele exige também que reflitamos sobre seus desafios locais. No caso brasileiro, seria preciso um reexame da transição democrática e de sua aposta na inclusão social como resposta para os anos autoritários, que talvez tenha roubado dos liberais uma arena de atuação legítima e democrática. O caso brasileiro, tão envolvido em si mesmo, pode oferecer um excelente prisma para entendermos os dilemas da democracia ao redor do mundo e do papel do indivíduo em suas relações políticas com seus semelhantes. 


\section{Referências}

ARENDT, H. A condição humana. Rio de Janeiro: Forense, 2004.

ARENDT, H. Philosophy and Politics. Social Research, New York, v. 57,

n. 1, 1990.

CARIELLO, G.; GRILLO, M. Facebook tira do ar página e perfis associados à onda de fake news contra Marielle. O Globo, 2018.

CYFER, Ingrid. A tensão entre modernidade e pós-modernidade na crítica à exclusão no feminismo. Tese (Doutorado) - Faculdade de Filosofia, Letras e Ciências Humanas, Universidade de São Paulo, São Paulo, 2009.

DAYAN, D.; KATZ, E. Media Events: The Live Broadcasting of History. Cambridge: Harvard University Press, 1994.

FAGGION, A. Por um liberalismo sem neutralidade. O Estado de S. Paulo, Estado da Arte, 2018.

FRASER, N. (Ed.). Social Justice in the Age of Identity Politics:

Redistribution, Recognition, and Participation. The Tanner Lectures on Human Values. Stanford: Stanford University, 1996.

GEERTZ, C. The Interpretation of Cultures. New York: Basic Books, 1973.

GEERTZ, C. Nova luz sobre a antropologia. Rio de Janeiro: Zahar, 2001.

HELENA, L. Marielle Franco: Mulher, negra, mãe e cria da favela da maré. M de Mulher, 19 mar. 2018.

LEVITSKY, S.;ZIBLATT, D. Como as democracias morrem. Rio de Janeiro: Zahar, 2018.

LILLA, M. The Once and Future Liberal: After Identity Politics. New York: Harper, 2017.

MESQUITA, L. Os últimos momentos de Marielle Franco antes de ser morta com quatro tiros na cabeça. BBC News Brasil, 2018.

MOYN, S. The Last Utopia: Human Rights in History. Cambridge, Mass.London: The Belknap Press of Harvard University Press, 2010.

PAIM, A. História do liberalismo brasileiro. São Paulo: Editora Mandarim, 1998. 
STULBERG, L. M.; CHEN, A. S. The Forgotten Origins of Affirmative Action in College and University Admissions, 1961-1969. Working Paper 2007-001, Gerald R. Ford School of Public Policy, Ann Arbor, 2008. 


\section{SOBRE AS AUTORAS}

\section{Adriana Sader Tescari}

Graduada em Direito pela Universidade de São Paulo (USP) e mestre em Diplomacia pelo Instituto Rio Branco. Diplomata desde 2002, serviu em Buenos Aires, Berlim e Tel Aviv. Atualmente, é chefe da Divisão do Levante no Ministério das Relações Exteriores. Áreas de interesse: gênero, meio ambiente e Oriente Médio. E.mail: adritescari@hotmail.com

\section{Ana Balbachevsky Guilhon Albuquerque}

Graduada em Relações Internacionais pela Pontifícia Universidade Católica de São Paulo (PUC/SP), mestranda em Relações Internacionais no Instituto de Relações Internacionais da Universidade de São Paulo (USP). Áreas de interesse: opinião pública política externa, gênero e política. E.mail: anabalbasky@gmail.com

\section{Ana Luiza Villela de Viana Bandeira}

Graduada em Direito pela Escola de Direito de São Paulo da Fundação Getúlio Vargas (FGV), mestre em Antropologia Social pela Universidade de São Paulo (PPGAS/USP). Integra o Núcleo de Antropologia do Direito (NADIR) da USP e atualmente é coordenadora do Innocence Project Brasil. Áreas de interesse: antropologia do direito, direito criminal, direitos humanos.E.mail: analuiza.bandeira12@gmail.com 


\section{Ana Paula Martin Martins}

Graduada em Direito pela Universidade de São Paulo (USP) e mestre em Direito Privado e Econômico pela Universidade Federal da Bahia (UFBA). É professora universitária e advogada orientadora de Escritório de Assistência Jurídica-Universitário. Áreas de interesse: direito constitucional, direito civil, direitos humanos. E.mail: anapaulamartin81@gmail.com

\section{Arthur Murta}

Graduado em Relações Internacionais pela Universidade Estadual da Paraíba (UEPB), mestre em Relações Internacionais pelo Programa de Pós-Graduação San Tiago Dantas (Universidade Estadual Paulista Júlio de Mesquita Filho - Unesp, Universidade Estadual de Campinas -Unicamp, Pontifícia Universidade Católica de São Paulo - PUC/SP) com estágio de pesquisa na Universidad de Chile, doutorando em Relações Internacionais na Universidade de São Paulo (USP), com bolsa Fundação de Amparo à Pesquisa do Estado de São Paulo (FAPESP). Professor do Departamento de Relações Internacionais da Pontifícia Universidade Católica de São Paulo (PUC/SP). Áreas de interesse: economia política internacional, política externa brasileira, estudos de gênero e migrações internacionais. E-mail: arthurmurta@usp.br

\section{Denise Vitale}

Graduada e doutora em Direito pela Universidade de São Paulo (USP). Pós-Doutora pelo European University Institute. Foi pesquisadora visitante na Universidade de Columbia. Professora associada do Instituto de Humanidades, Artes e Ciências prof. Milton Santos (IHAC) da Universidade Federal da Bahia (UFBA). Professora e coordenadora do Programa de Pós-Graduação em Relações Internacionais da UFBA. Pesquisadora do Núcleo Direito e Democracia do Centro Brasileiro de Análise e Planejamento. É bolsista Produtividade em Pesquisa (PQ-2) do CNPq. Áreas de interesse: teoria política, teoria democrática, direitos humanos, meio ambiente, participação, povos indígenas e gênero. E.mail: denise.vitale@ufba.br 


\section{Fernanda Matsuda}

Graduada em Direito e em Ciências Sociais pela Universidade de São Paulo (USP). Mestre e doutora pelo Programa de Pós-Graduação em Sociologia da Faculdade de Filosofia, Letras e Ciências Humanas da USP. Professora adjunta da Universidade Federal de São Paulo (Unifesp) e coordenadora do Núcleo de Apoio ao Estudante do Campus Osasco. Áreas de interesse: gênero, direitos humanos, sistema de justiça criminal, sistema socioeducativo, punição. E.mail: fematsuda@unifesp.br

\section{Flavia de Ávila}

Graduada em Direito pela Pontifícia Universidade Católica do Paraná PUC/PR), mestre em Direito e Relações Internacionais pela Universidade Federal de Santa Catarina (UFSC) e doutora em Direito Público pela Pontifícia Universidade Católica de Minas Gerais (PUC Minas). Professora do Departamento de Relações Internacionais e do Programa de Pós-Graduação em Direito da Universidade Federal de Sergipe (UFS). Áreas de interesse: direito internacional público, direito internacional privado, direitos humanos, direito do trabalho, direito da integração, trabalhador estrangeiro e relações internacionais. E.mail: flaviadeavila@ gmail.com

\section{Giselle Amorim de Souza}

Graduada em Direito pela Universidade Católica do Salvador (UCSal), mestranda em Relações Internacionais pela Universidade Federal da Bahia (UFBA). Membro da Comissão de Direito Internacional da Ordem dos Advogados do Brasil - Seção do Estado da Bahia (OAB/ BA). Áreas de interesse: cooperação jurídica internacional, gênero e migrações. E.mail: giselleamorim.jur@gmail.com 


\section{Heloisa Pait}

Graduada em Economia pela Universidade de São Paulo (USP). Doutora em Sociologia pela New School for Social Research (Nova York). Professora de sociologia da Universidade Estadual Paulista Julio de Mesquita Filho (Unesp). Foi bolsista da Comissão Fulbright. Áreas de interesse: Sociologia da comunicação, esfera pública e democracia, desenvolvimento social e econômico, educação superior e estudos judaicos. E.mail:heloisa.pait@fulbrightmail.org

\section{Ingrid Cyfer}

Graduada em Direito pela Universidade Federal do Rio de Janeiro (UFRJ), é mestre em Direito Internacional e doutora em Ciência Política pela Universidade de São Paulo (USP). Professora de Teoria Política do Curso de Ciências Sociais da Universidade Federal de São Paulo (Unifesp). Pós-doutora pelo Dartmouth College. Pesquisadora do Núcleo Direito e Democracia do Centro Brasileiro de Análise e Planejamento (CEBRAP), São Paulo. Áreas de interesse: teoria política contemporânea, direitos humanos e teoria crítica, teorias feministas e teorias psicanalíticas.

E.mail:ingridcy@gmail.com

\section{Janina Onuki}

Graduada em Ciências Sociais, mestre e doutora em Ciência Política pela Universidade de São Paulo (USP). Pós-doutora pela School of Public and InternationalAffairs da North CarolinaStateUniversity (2013). Professora Titular e Diretora do Instituto de Relações Internacionais da USP. Coordenadora do Grupo de Relações Internacionais da Associação LatinoAmericana da Ciência Política, coordenadora do Núcleo de Estudos Comparados e Internacionais (NECI-USP). É bolsista Produtividade em Pesquisa (PQ-2) do CNPq. Áreas de interesse: política externa, integração regional, opinião pública, gênero e relações internacionais. E.mail:janonuki@usp.br 


\section{Karyna Sposato}

Graduada e mestre em Direito pela Universidade de São Paulo (USP). Doutora em Direito pela Universidade Federal da Bahia (UFBA). Professora Adjunta do Departamento de Direito da Universidade Federal de Sergipe (UFS). É diplomada no Terceiro Ciclo pelo Programa de Doutorado em Problemas Atuais do Direito Penal e da Criminologia da Universidade Pablo Olavide (UPO) em Sevilha/ Espanha. Coordenadora do Programa de Pós-Graduação em Direito (PRODIR) da UFS. Áreas de interesse: Direito da Criança e do Adolescente, Direitos Humanos e Direito Penal e Criminologia. E.mail: karyna.sposato@gmail.com

\section{Maria Aparecida Azevedo Abreu}

Graduada em Direito pela Universidade de São Paulo (USP), mestre e doutora em Ciência Política pela USP. Professora do Instituto de Pesquisa e Planejamento Urbano e Regional - IPPUR da Universidade Federal do Rio de Janeiro (UFRJ). Áreas de interesse: teoria política; igualdade entre homens e mulheres nas políticas públicas; federalismo.

E.mail:mazabreu75@gmail.com

\section{Mariângela Gama de Magalhães Gomes}

Graduada, mestre, doutora e livre-docente em Direito pela Universidade de São Paulo (USP). Professora Associada de Direito Penal da Faculdade de Direito da USP. Membro do Instituto Brasileiro de Ciências Criminais (IBCCRIM) desde 1997, onde foi Presidente em 2013/14. CoordenadoraChefe da Revista Brasileira de Ciências Criminais (Qualis A1) em 2017/18; Vice-Presidente do Grupo Brasileiro da Associação Internacional de Direito Penal (AIDP) no período 2015/19. Áreas de interesse: direito penal, direitos humanos, gênero e sistema punitivo.

E.mail:mariangela@usp.br 


\section{Marta Rodriguez de Assis Machado}

Graduada, mestre e doutora em Direito pela Universidade de São Paulo (USP). Professora da Escola de Direito de São Paulo da Fundação Getúlio Vargas (FGV), pesquisadora permanente do Centro Brasileiro de Análise e Planejamento e coordenadora do Núcleo de Estudos sobre o Crime e a Pena da Direito FGV. Foi pesquisadora visitante da Universidade de Barcelona, do Instituto Max Planck de Direito Internacional e Estrangeiro em Freiburg, Alemanha; do Instituto Latino Americano da Freie Universität Berlin e da Universidade da Califórnia, Berkeley, da Universidade de Toronto e da Columbia Law School. Áreas de interesse: direito penal, teoria geral do direito e sociologia do direito.

E.mail:martamachado@fgv.br

\section{Olivia Alves Barbosa}

Graduada e mestre em Direito pela Universidade de São Paulo (USP). Mestre em Action et Droit Humanitaires - Université Paul Cézanne Aix Marseille III. Pesquisadora do Centro Brasileiro de Análise e Planejamento (Cebrap). Áreas de interesse: direitos, religião, orientação sexual e democracia. E.mail: olivia.a.barbosa@gmail.com

\section{Paula Alves Seixas}

Graduada em Relações Internacionais pela Universidade Federal de Sergipe (UFS). Integrante do grupo de pesquisa Natureza Humana, pluralismo e multiculturalismo no âmbito dos Direitos Humanos. Áreas de interesse: teorias feministas, direitos humanos, direitos sexuais e reprodutivos.Email: paula.a.seixas@gmail.com 


\section{Renata Nagamine}

Graduada, mestre e doutora em Direito pela Universidade de São Paulo (USP). Pós-doutoranda do Programa de Pós-Graduação em Relações Internacionais da Universidade Federal da Bahia (UFBA), com pesquisa financiada pela Coordenação de Aperfeiçoamento de Pessoal de Nível Superior (Capes) (bolsista pelo Programa Nacional de Pós- Doutorado - PNPD). Em 2018 foi pesquisadora visitante no Laureate Program in International Law da Universidade de Melbourne e é colaboradora no Centro Brasileiro de Análise e Planejamento (Cebrap). Áreas de interesse: direitos humanos; direito internacional público; direito internacional humanitário, gênero, cosmopolitismo, uso da força no direito internacional.E.mail: renagamine@gmail.com

\section{Vitória Sacramento Moreira}

Graduada em Relações Internacionais pela Universidade de Brasília (UnB). Mestranda em Relações Internacionais e graduanda em Estudos de Gênero e Diversidade, ambos na Universidade Federal da Bahia (UFBA). Áreas de interesse: segurança internacional, estudos de gênero e mulheres, paz e segurança. E.mail: vitoria.sms@gmail.com 
9

Este livro foi publicado no formato $17 \times 24 \mathrm{~cm}$ utilizando as fontes Freight e Freight Sans Miolo em papel Alcalino $75 \mathrm{~g} / \mathrm{m}^{2}$ Capa em Cartão Supremo $300 \mathrm{~g} / \mathrm{m}^{2}$ Impresso naEDUFBA Impressão de Capa e Acabamento da I. Bigraf 400 exemplares 